\title{
WestVirginiaUniversity
}

THE RESEARCH REPOSITORY @ WVU

Graduate Theses, Dissertations, and Problem Reports

2015

\section{The Anti-Imperialist Empire: Soviet Nationality Policies under Brezhnev}

Jason A. Roberts

Follow this and additional works at: https://researchrepository.wvu.edu/etd

\section{Recommended Citation}

Roberts, Jason A., "The Anti-Imperialist Empire: Soviet Nationality Policies under Brezhnev" (2015). Graduate Theses, Dissertations, and Problem Reports. 6514.

https://researchrepository.wvu.edu/etd/6514

This Dissertation is protected by copyright and/or related rights. It has been brought to you by the The Research Repository @ WVU with permission from the rights-holder(s). You are free to use this Dissertation in any way that is permitted by the copyright and related rights legislation that applies to your use. For other uses you must obtain permission from the rights-holder(s) directly, unless additional rights are indicated by a Creative Commons license in the record and/ or on the work itself. This Dissertation has been accepted for inclusion in WVU Graduate Theses, Dissertations, and Problem Reports collection by an authorized administrator of The Research Repository @ WVU.

For more information, please contact researchrepository@mail.wvu.edu. 
The Anti-Imperialist Empire: Soviet Nationality Policies under Brezhnev

\author{
Jason A. Roberts
}

Dissertation submitted to the Eberly College of Arts and Sciences at West Virginia University

in partial fulfilment of the requirements for the degree of

Doctor of Philosophy in History

Mark B. Tauger, Ph.D., Chair

Robert E Blobaum, Ph.D.

Joseph M. Hodge, Ph.D.

Joshua W. Arthurs, Ph.D.

Christian Peterson, Ph.D.

Department of History

Morgantown, West Virginia

2014

Keywords: Soviet Union, imperialism, decolonization, nationalism, developed socialism, Leonid Brezhnev, Central Asia, Ukraine

Copyright 2014 Jason A. Roberts 


\section{ABSTRACT \\ The Anti-Imperialist Empire: Soviet Nationality Policies under Brezhnev}

Jason A. Roberts

This dissertation argues that the Soviet Union functioned as an empire despite its decidedly anti-imperialist rhetoric. Beginning in the 1920s, Bolshevik policies transformed the former Russian Empire into a new type of empire that was based on Marxist-Leninist ideology. Moreover, the Bolshevik policy of korenizatsiia as well as Marxist-Leninist rhetoric promoted the development of a decolonization process among the non-Russian peoples of the USSR in the 1920s and 1930s. Although Stalin abandoned korenizatsiia in the 1930s in favor of greater emphasis on Russification, the decolonization process continued into the Brezhnev period of the 1960s and 1970s. This decolonization process quickly rose to the surface in the 1980s as a result of Gorbachev's reforms.

This dissertation focuses on the Brezhnev leadership's handling of the Soviet nationality question as this period represents the final effort to maintain and to consolidate further the Soviet Empire. Brezhnev's doctrine of Developed Socialism emphasized the continued rapprochement of the nations of the USSR into a supranational Soviet nation, the importance of the Russian language as the language of inter-national communication within the Soviet Union, the further consolidation of power at the center of the Soviet Union at the expense of Union Republic sovereignty, and the treatment of the USSR as a single economic complex. The tenets of Developed Socialism, then, are imperialist in nature as they promoted the Russian language at the expense of non-Russian languages and they focused on the greater concentration of power in Moscow and the erosion of Union Republic sovereignty. The ratification of a new USSR Constitution in 1977 and of new Union Republic constitutions in 1978 is the high-water mark of Brezhnev's imperialist policies. The Brezhnev leadership's imperialist policies, however, were rooted in Marxist-Leninist ideology as an analysis of the essays written by Lenin and Stalin will show.

Although Brezhnev's policies were imperialistic, they were implemented unevenly across the USSR, resulting in continued diversity within the USSR in terms of nationality policy. Moscow kept a tighter rein on the western republics, such as Ukraine, while maintaining looser control over the Central Asian republics. As evidence of this, the CPSU Politburo removed Petro Shelest from his post as First Secretary in Ukraine for tolerating manifestations of Ukrainian nationalism while Sharaf Rashidov in Uzbekistan kept his post as First Secretary until his death in 1983 despite increasing displays of Uzbek nationalism there in the 1970s. 
This dissertation also argues that a decolonization process began in the Soviet Union as early as the 1920s, but that this process is reignited by Khrushchev's policies in the 1950s. The Brezhnev leadership's focus on further consolidating power at the center could not stop this decolonization process and in some ways, it contributed to the continued growth of a decolonization process among the non-Russian peoples of the USSR. In the 1960s, nationalist dissent re-emerged, centered primarily in the western Soviet Union, which continued into the 1980s. Though it did not pose a direct threat to the Soviet regime's stability, nationalist dissent did encourage the Brezhnev leadership to rely further on the tenets of Developed Socialism.

This dissertation also compares Soviet nationality policies with similar policies enacted by other modern empires such as the British and French empires in the 19th and 20th centuries. Thus, much of Chapter One compares the Soviet Union with the British and French empires to demonstrate that the Soviet Union did indeed function as an empire. Moreover, Brezhnev's strategy of re-invigorating Soviet imperial policies through the tenets of Developed Socialism represented the Soviet Union's "second colonial occupation." Just as the British sought to rekindle their empire in East Africa and Malaya after World War II, the Soviet Union under Brezhnev acted to renew its imperial control over the Union Republics in the 1970s. The Brezhnev leadership's pursuit of grandiose construction and modernization projects such as the Baikal-Amur Mainline Railway are not unlike Britain's groundnut scheme in Tanganyika after World War II. Through comparing the Soviet Union with other modern empires, this dissertation places Soviet history and practices in a world history context. 


\section{ACKNOWLEDGMENTS}

Knowledge is one of the greatest gifts anyone can bestow upon another person. Over the last several years as I worked toward the Master's degree and now the Doctor of Philosophy, Dr. Mark Tauger has shared with me his supreme knowledge and expertise in all aspects of Soviet history. He has also showed tremendous patience with me, particularly as I labored on this dissertation. I cannot begin to repay the debt I owe to Dr. Tauger.

I also would like to thank the members of my committee, Dr. Robert Blobaum, Dr. Joseph Hodge, Dr. Joshua Arthurs and Dr. Christian Peterson, for agreeing to serve and for their expertise and guidance.

As anyone who has pursued a Ph.D. in history knows, it is a long, arduous process that tests one's sanity. I would have lost mine long ago if it were not for the support and great friendship shown to me by my fellow graduate students at West Virginia University. My deepest

thanks go to Isaac Emrick, Ben Scharff, Alec Upward, and Mehmet Tepeyurt for their friendship, support, and for the great conversations we have had over the years.

The support of my parents, Rick and Mary, has been invaluable. Their constant moral support - and occasional financial support - made this dream come true in many ways. They instilled in me at an early age the value of education. I simply can't put into words my gratitude for all they have done.

Finally, and most importantly, thanks to my wife Amber who has had to tolerate countless weekends alone as I labored on this project. She is incredible and she kept me strong when I needed it the most. I love you!

This work is dedicated to my son, Harrison. May you always remain curious about the world! 


\section{TABLE OF CONTENTS}

Introduction

$i-x i$

\section{Chapter 1}

The Formation of the Soviet Empire

$1-59$

Chapter 2

Brezhnev's Anti-Imperialist Empire

$60-103$

Chapter 3

Developed Socialism as Soviet Imperialism

$104-128$

Chapter 4

Republic Leaders and Developed Socialism

\section{Chapter 5}

Dissent and Decolonization

\section{Chapter 6}

All-Union and Republic Constitutions

$214-257$

Chapter 7

Developed Socialism as Second Colonial Occupation

$258-289$

Conclusion

$290-298$

Endnotes

$299-311$

Bibliography

$312-322$ 


\section{INTRODUCTION}

\section{The Anti-Imperialist Empire}

The concept that the Soviet Union was an empire rather than a multinational state is not a new one in the historiography of Soviet history. Indeed, John Keep and Terry Martin, just to name a couple, have written books with "empire" in the title. However, the term "empire" is often used by historians when referring to Soviet nationality policy without explaining why the Soviet Union functioned as an empire despite its consistently strong anti-imperialist rhetoric. The purpose of this study, then, is to analyze Soviet nationalities policy within an imperialist framework - in other words, to demonstrate that the Soviet Union was indeed an empire and that by the Brezhnev years, a decolonization process characterized by rising non-Russian nationalism had begun and would quickly come to the surface in the early years of Gorbachev's term in office. John Keep called the Soviet Union "The Last of the Empires"1 and in many respects this is true. But what is often missing from the historiography is precisely why the Soviet Union can be called an empire and why Soviet nationalities policy became imperialistic after the end of korenizatsiia policies in the early 1930s.

Secondly, this study will demonstrate that by the Brezhnev era, the Soviet Union functioned as an empire, albeit a different kind of empire that was based on Leninist ideology and claimed to be anti-imperialist. The original intent of Lenin and the Bolshevik Party was obviously not to create an empire in the traditional sense of the term. Rather, they sought to liberate the peoples they believed had been oppressed by the Tsarist regime by giving them equal status with the Russians and, of course, by liberating them from capitalist oppression as well as from the constraints imposed by what Lenin called Great Russian chauvinism. Yet after the heady days of Bolshevik victory in 1917 and then after the establishment of Bolshevik rule in the national areas after the Civil War, nationality policy grew increasingly imperialistic, at least in 
Western terms. As will be seen, the circumstances of history, Bolshevik ideology, and policies undertaken by Stalin worked to turn the Soviet state into an anti-imperialist empire.

Third, it will be shown that the Soviet Union did not function as a monolithic empire in which all areas of the vast country were dealt with in exactly the same way. Instead, by the Brezhnev era, we can observe and speak of diversity within the USSR - or four sub-empires within the greater Soviet Empire - in terms of Soviet nationalities policy. The four sub-empires consisted of the following regions: the Russian Soviet Federated Socialist Republic (RSFSR) and its component Autonomous Soviet Socialist Republics (ASSRs) and other autonomous regions; the Western Soviet Union (led by the other Slavic republics of Ukraine and Byelorussia, as well as the three Baltic republics and Moldavia); the Transcaucasus comprised of the Soviet Socialist Republics of Georgia, Armenia, and Azerbaijan; and finally Soviet Central Asia consisting of the Uzbek, Tajik, and Kyrgiz Soviet Socialist Republics. The Kazakh SSR is a special case as it formed a bridge between Central Asia and the RSFSR. We see the emergence of various different sub-empires in the early policies of the Bolsheviks immediately following the Civil War. This differentiation of various sub-empires developed as the result of the historical legacy of the late Tsarist period, the varying levels of development of the many different nations and nationalities inhabiting these areas, Bolshevik ideology, foreign policy concerns, and political and economic considerations. The diversity in Soviet nationality policy can be observed throughout the course of Soviet history, but it changed and evolved over time due to various reasons ranging from levels of development to foreign policy concerns.

This study will focus on the four sub-empires outlined above which were apparent during the Brezhnev era. In essence, during the Brezhnev era, the Soviet regime's treatment of each sub-empire varied based on a number of factors. The Western Soviet Union was kept on a 
tighter leash by Moscow due primarily to foreign policy and ethnic concerns as well as incidents that occurred during World War II; the Transcaucasus had a bit more freedom due to historical legacies and not so much due to foreign policy concerns; Central Asia perhaps had the most "favorable" treatment again because of historical legacies but also due to Moscow's apparent inability to find a way to control Islam in that region and - as with the Western Soviet Union foreign policy concerns. Finally, the RSFSR formed a special case. Because the Russian Social Democratic Labor Party (Bolshevik) later became the Communist Party of the Soviet Union with the other national parties viewed as branches of the CPSU, Russia did not technically have its own Communist Party as the Ukrainians, Uzbeks, and all of the other major nationalities had. In essence, the CPSU by default seemed to be the party for the RSFSR. Moreover, if the Soviet Union indeed functioned as an empire, the Russians were the imperialists, which meant they received the most favorable "treatment" of all of the other nationalities. For this reason, Russian nationalist sentiment was tolerated by the Soviet leadership more than non-Russian nationalist manifestations. But, whereas the non-Russian union republics had their own native leaderships such as Sharaf Rashidov in Uzbekistan - which could serve as a possible rallying point for budding decolonization movements - Russia did not have such persons, at least not until the rise of Boris Yeltsin in the late 1980s. So the RSFSR forms a special kind of Soviet Union within the Soviet Union - it enjoyed the status of primus inter pares among the peoples of the Soviet Union and Russian nationalism was tolerated more than non-Russian nationalism - but many Russian figures after World War II resented the fact that the RSFSR lacked many of the national institutions that the other fraternal union republics had. Finally, the RSFSR itself formed an empire within the greater Soviet empire as it contained dozens of minority nationalities and their respective ASSRs, autonomous oblasts, etc. 
Fourth, while I will refer to the entire course of Soviet history, the primary focus of this study is on the Brezhnev era. I have chosen to examine the Brezhnev era more closely for a variety of reasons. The primary reason is that it is during the Brezhnev era that the Soviet Union reaches its mature stage of development. For the first time in its history, the Soviet Union under Brezhnev is not either dealing with or recovering from a major crisis, nor is it undergoing major economic or ideological change. For example, in Lenin's brief time as Soviet leader, the country went through a devastating civil war while also trying to decide what a socialist state actually looks like. The long Stalin era was dominated by Stalin's cultural revolution, industrialization, collectivization, and then World War II. Much of the Khrushchev period was spent recovering from World War II, confronting the onset of the Cold War, suppressing rebellion in Hungary, and Khrushchev's own often disruptive domestic policies. Conversely, the Brezhnev leadership presided over a relative period of calm and stability, save for the Soviet-led invasion of Czechoslovakia in 1968. Indeed, it is the only period of Soviet history in which we are able to see the Soviet Union at peace and free from major disruptions. Therefore, it is possible in this time period to observe the maturation of Soviet nationalities policy and thus to examine the empire at its apogee. Moreover, it is during the Brezhnev era that the forces which will ultimately lead to the dissolution of the Soviet Union are coming to their maturation, most notably in the areas of economics and the nationalities issue. A decolonization process was maturing in the Soviet Union during this period, which required the Brezhnev leadership to counteract. As will be demonstrated, the Brezhnev leadership sought to remedy the problem of decolonization by attempting to further consolidate the empire through the concept of Developed Socialism and its renewed emphasis on the rapprochement of nations, the Soviet Union as a "single economic complex", the importance of the Russian language as the means for inter- 
national communication within the USSR, and the evolution of a new supra-national Soviet nation that would be the natural result of the ongoing rapprochement of nations. While the Brezhnev leadership seemed to be able to keep a lid on the budding decolonization process through various means which will be examined in detail throughout the course of this study, the same could not be said of the Gorbachev leadership. As will be shown in the Conclusion, Gorbachev's zeal to reform the system inadvertently lifted the lid that Brezhnev had been able to keep on the decolonization process. This resulted in perhaps the greatest irony in the entire course of Soviet history - the reformist, pro-democratic Gorbachev had to resort to force in an attempt to hold the empire together, while Brezhnev never used armed troops to maintain the empire.

In addition to the reasons outlined above, I focus my study on the Brezhnev era because this is a time period that has been largely overlooked by historians for the last 25 years. With a few exceptions, the majority of the works on the Brezhnev period were written either during Brezhnev's tenure or immediately thereafter. Thus, the historiography for the Brezhnev era suffers from age - much of the work that does exist is quite good, but is naturally lacking as it was produced before the collapse of the Soviet Union. The Brezhnev era tends to be overlooked most likely because the key archives concerning this period remain closed to researchers. This also helps to explain why so many works on the Stalin period have appeared over the last 20 years - those archives are now available. Therefore, this study will rely on the words spoken and written by the Brezhnev-era leadership at the time, which were publicly available then, in addition to a few items which have become public in the last 20 years. Many of these sources have been used previously such as prominent speeches made at All-Union Party congresses and items found in the Soviet press. Other sources used in this study, however, have not been used, 
such as the stenographic reports from republic-level Party congresses, which reveal some significant subtleties. The lack of Politburo records notwithstanding, it is now time to begin to take a fresh look at this crucial period in Soviet history and to take a fresh approach. This will be one of the main contributions that this study will make to the existing historiography.

Finally, "empire", “imperialist", and "decolonization" along with their synonyms are loaded terms which have acquired powerful connotations, especially since the end of World War II. As will be seen in this study, the Soviet Union was one of the first states in the world to denounce imperialism and champion the causes of decolonization, especially during the Cold War. But it must be emphasized that by classifying the Soviet Union as an empire, I in no way intend to pass judgment on the Soviet Union. It is not my intention to label the Soviet Union as an "evil empire" unlike other works on the issue of the Soviet nationalities question. Rather, the purpose of studying the Soviet Union as an empire is to provide further context in the study of the Soviet nationalities question by placing it in a more global milieu. Moreover, placing the Soviet Union into an imperial framework provides a useful analytical tool for examining the implementation of Soviet nationalities policies as well as for analyzing the eventual dissolution of the Soviet Union. And lastly, while this study does focus on the Brezhnev era because it is during that time that the forces which will ultimately help to dissolve the Soviet Union are becoming manifest, this study is not intended to be an obituary of the Soviet Union. The purpose, instead, is to examine Soviet nationalities policy through the lens of the Brezhnev leadership by discussing the many rationales that existed for the ways in which the Brezhnev leadership sought to maintain the empire. This study should not be construed as "an autopsy for an empire", to borrow the title from Dmitrii Volkogonov's well-known work. ${ }^{2}$ Instead, this study will analyze how the Soviet empire lived and thus broaden the overall understanding of the 
functioning of the Soviet Union as an empire, particularly the understanding of the Brezhnev leadership's handling of the nationalities issue. Ultimately, this study will bring renewed attention to the Brezhnev era as this period is unfortunately largely overlooked in the historiography.

Chapter One will focus on defining empire and will explain why the Soviet Union did indeed function as an empire. To do this, I will review some of the literature on empire in an attempt to provide a working definition for empire. Then, I will provide examples of decolonization processes in other world empires in order to place the Soviet Union's decolonization process in a global perspective. This will be followed by a review of Soviet nationalities policies in the 1920s and 1930s, with focus on korenizatsiia, which actually began the decolonization process in the Soviet Union. The experience of World War II will also be reviewed as this conflict presented the Soviet Union with an opportunity to expand territorially due to the Nazi-Soviet Non-Aggression Pact. The Soviet annexation of the Baltic states and western Ukraine in particular led to the growth of underground guerilla movements fighting against Soviet imperial expansion. Finally, it will be shown that Stalin altered, but did not completely abolish, korenizatsiia policies due to political, ideological, and pragmatic concerns. Stalin's alterations, it will be seen, consolidated the Soviet Empire and laid the foundation for the nationalities policies pursued by Khrushchev and Brezhnev. Because of the tsarist historical legacy, Bolshevik ideology, and Stalin's actions in the 1930s, the Soviet Union evolved into a decidedly anti-imperialist empire. It would be left to Stalin's successors to keep a handle on this rather unusual arrangement.

Chapter Two will discuss Khrushchev's de-Stalinization process and its impact on the Soviet Empire. It will then review the early years of the Brezhnev era in order to provide an 
overview of the situation that Brezhnev inherited in 1964. In addition, a key focus of Chapter Two will be on examining the theoretical basis for Soviet nationality policy. This chapter will review the relevant writings of Lenin and Stalin on the nation and contrast these theories with Western theories on the nation, national identity and national development. The purpose will be to show that while the Soviet Union did act like an empire, it could not possibly be viewed as an empire by the Soviet leadership. In other words, while Western observers may decry certain Soviet policies as imperialistic and oppressive toward minority nations within the USSR, in the Kremlin's eyes these same policies are indeed based on sound Marxist-Leninist theory. While the intent will not be to defend Soviet policies, it will seek to understand these policies through the prism of Marxism-Leninism. I think this is necessary as much of the existing historiography seems to dismiss Soviet nationality policy as oppressive, without trying to look at the situation through the eyes of the Soviet leadership. ${ }^{3}$ Moreover, this theoretical review will help to explain why Soviet leaders - especially the Brezhnev leadership - undertook policies that to outside observers may look contradictory or outright repressive.

Chapter Three will focus on the primary strategy used by Brezhnev for maintaining the Soviet Empire - the concept of Developed Socialism. In this chapter, the theoretical basis for Developed Socialism will be analyzed in order to show that the primary tenets of Developed Socialism - the rapprochement of nations, the promotion of Russian as the means for international communication within the Soviet Union, the Soviet Union as a single economic complex, and the coming of the new supra-national Soviet nation - aimed to consolidate further the Soviet Empire. Developed Socialism, as will be demonstrated, is an imperialist policy, yet imperialist in the Leninist sense of the term. In other words, Developed Socialism emerges as a theory that envisions the further consolidation of the Soviet Empire but it is firmly rooted in 
Leninist theories. Therefore, while the tenets of Developed Socialism are indeed imperialist, to the Soviet mind they represented the natural evolution of the Soviet Union in its path toward communism as predicted by Marxism-Leninism.

Chapter Four will focus on Developed Socialism in action. In this chapter, I will illustrate the incomplete nature of the application of the tenets of Developed Socialism through the analysis of republic party congress reports and the effects Developed Socialism had on the republic Party leaderships. Moreover, I will demonstrate that certain factors - notably Brezhnev's trust in cadres philosophy and Soviet foreign policy - acted to impede the complete fulfillment of the principles of Developed Socialism.

Chapter Five will focus on nationalist dissent in the Soviet Union during the Brezhnev period. Moderate nationalist dissent centered on opposition to linguistic and cultural Russification and did not demand independence from the Soviet Union. Moderate dissidents such as Ivan Dziuba used Marxism-Leninism to criticize Soviet nationality policies in much the same way that Ho Chi Minh and other leaders of colonial peoples around the world used Communism as a weapon against imperialism. Radical nationalist dissidents, on the other hand, demanded independence from the Soviet Union and frequently referred in samizdat literature to the imperial nature of the Soviet Union. Though the nationalist dissident movement did not pose an immediate threat to the Soviet regime during the Brezhnev period, the Soviet authorities responded to this dissent through repressive measures as well as through continued reliance on the tenets of Developed Socialism. As this chapter will show, nationalist dissent in the USSR represented a decolonization process that was similar to other decolonization movements around the world. 
Chapter Six will analyze the new USSR Constitution ratified in 1977 and the new union republic constitutions ratified in 1978 and it will compare these new constitutions with the prior constitutions that were ratified in the Stalin period. These new constitutions were the main achievement of Developed Socialism as they enshrined in the Soviet Union's fundamental laws the core concepts of Developed Socialism and they further consolidated the Soviet Empire by eroding the sovereignty of the union republics. However, the process was not complete due to resistance at the union-republic level.

Chapter Seven will evaluate Developed Socialism as the Soviet Union's “second colonial occupation." Just as Britain and France sought to reassert control over parts of their empires after World War II, the policies of Developed Socialism along with Brezhnev's grandiose projects such as the Baikal-Amur Mainline Railway constitute the reassertion of Soviet imperial control over the periphery. This chapter will compare Soviet policies and projects initiated by Brezhnev with the Groundnut Scheme in British East Africa. In addition, this chapter will also discuss the resurgence of underground Islam in Central Asia and the challenge it posed to the Brezhnev leadership in the late 1970s. Because the Brezhnev leadership did not fully understand the nature of resurgent underground Islam and because of foreign policy concerns, this movement was able to develop and ultimately led to the growth of radical Islam in the 1980s and 1990s.

Finally, I will conclude this study with an overall evaluation of Brezhnev's success in maintaining the Soviet Empire. As is well known in the historiography, the factors that led to the collapse of the Soviet Empire in 1991 had their roots in the Brezhnev period, particularly the nationalities issue. Overall, I argue that Brezhnev sought to maintain the Soviet Empire through a greater consolidation of power in Moscow at the expense of Union Republic sovereignty, but 
that these efforts were hampered by historical legacy, Brezhnev's own trust in cadres philosophy, demographic trends and the pressures of Soviet foreign policy. In the end, however, Mikhail Gorbachev proved to be the ultimate anti-imperialist imperialist as he actually abandoned certain of Brezhnev's more conciliatory measures toward the nationalities and, unlike Brezhnev, Gorbachev resorted to the use of military force in a last ditch futile attempt to hold the Soviet Empire together. 


\section{CHAPTER ONE}

\section{THE FORMATION OF THE SOVIET EMPIRE}

\section{Defining Empire}

Since the Akkadians established the world's first empire in the third millennium BCE, empire has been a consistent component of world history. For the last 5,000 years, innumerable empires have risen and fallen, leaving an indelible imprint on the history of the world. Yet at times it seems difficult to identify precisely what an empire is. What follows is a brief overview of the historiography of empire and a discussion as to what actually constitutes an empire. Once a workable definition of empire has been determined, I will then discuss the process of decolonization. The decolonization process is important because all empires have dissolved into multiple successor states often, but not always, nation-states that began to take shape under the aegis of empire. Therefore, the decolonization process reveals much about the imperial character of the empire in dissolution. These concepts will be referred to throughout this study, so it is vital that a workable definition of them is provided at this stage. This chapter will then conclude with a review of early Soviet nationalities policy to demonstrate that the Soviet Union developed into an accidental empire and that early Bolshevik policies themselves set into motion the decolonization process that would later confront the Brezhnev leadership.

Empires of course have existed since antiquity, but the focus here will be on modern empires and the modern historiography on empires and imperialism as this is the context in which Lenin analyzed imperialism and in which the Soviet Empire existed. Indeed, as will be discussed in Chapter Two, Lenin himself participated in the modern historiography by offering his own interpretation of empire and imperialism. As it turns out, it is not so easy to simply 
define empire. In some cases, it seems clear that an entity is an empire - the British and French Empires in the nineteenth and twentieth centuries quickly come to mind. However, in others, empire seems to be in the eye of the beholder - the Soviet Union and the United States may be placed in this category. Despite the many ambiguities and nuances associated with identifying empire, some basic observations can be made which will provide a workable framework in which to analyze the Soviet nationalities issue.

After reading several studies of empires, I have found that Michael Doyle in his 1986 study Empires offers the most concise and widely applicable definition. ${ }^{1}$ Doyle defines empire as "a relationship, formal or informal, in which one state controls the effective political sovereignty of another political society. It can be achieved by force, by political collaboration, by economic, social, or cultural dependence." 2 Imperialism, then, is the act "of establishing or maintaining an empire."3 The Soviet Union certainly fits this model. The authorities in Moscow did indeed control the political sovereignty of the non-Russian societies and it achieved this control through force, collaboration, and economic dependence.

A crucial component of empire is the existence of a center (or metropole) and a periphery along with the concomitant relations between the two. Doyle defines a metropole as having three main elements: "first, a strong, united, central government; second, a thorough sense of public legitimacy or community, widely shared among the governing population, whether elite or mass; and third, a substantial degree of social differentiation."

Center-periphery relations are a key component of empires and, according to Doyle, help to distinguish between formal and informal empire. Doyle describes formal empire as "rule by annexation and government by colonial governors supported by metropolitan troops and local collaborators - the Roman pattern." Conversely, informal empire involves indirect rule of the 
periphery by the metropole. Doyle argues that the Delian League is a classic example of informal empire as Athens dominated its allies through "bribes and manipulation of dependent collaborating elites, over the legally independent peripheral regime's domestic and external politics. ${ }^{, 6}$ A more modern example of what could be considered an informal empire is a powerful state's economic domination of less powerful states. Some theorists claim that the United States today is an informal empire because of its dominant economic role in the postWorld War II world - particularly in Latin America.

Finally, a key characteristic of empire is what Doyle calls the Augustan Threshold. Using Rome's transition from republic to empire as the classic example, the Augustan Threshold, according to Doyle, is the process of centralizing power in the metropole while simultaneously incorporating the periphery into a single imperial entity. In other words, when Augustus won power in Rome after a long series of civil wars, he successfully removed imperial politics from the machinations of the power brokers in Rome itself. Augustus therefore was able to create a new bureaucracy that answered solely to Augustus, which enabled the new emperor to effect policies empire-wide, thus separating the city of Rome's politics from overall imperial policies. According to Doyle, "Augustus established a bureaucracy that put his, its own, and the empire's interests before any specifically Roman demands." ${ }^{7}$ The result was the integration of "the political, social, economic, and cultural systems of the periphery and the metropole. Joining elite to mass and region to region, they provide a social basis for authority and coordination." Without such integration of the periphery with the metropole, the periphery would spin out of the metropole's control because of centripetal forces tearing the periphery away from the metropole's control or as a result of another power taking control of the periphery, or both. The Augustan Threshold is thus necessary to consolidate the metropole's power over the periphery. 
An empire, then, is a political entity of relatively large geographical extent that is characterized by a distinct metropole exercising power over a distinct periphery or peripheries. The metropole can be distinguished from its periphery (or peripheries) by observing its power relationship with the periphery. As Doyle and others have explained, this power relationship can be formal (i.e. direct rule over the periphery) or informal (indirect control through economic, military, or some other form of domination while the periphery retains its legal independence). In addition, modern empires have a key racial or national distinction between the metropole and the periphery. The metropole is dominated by one race or nationality and rules over a periphery that is of a different race or nationality or is multinational. Thus, in the Russian Empire, Russians predominated in the metropole while the periphery consisted of a myriad of nonRussian peoples. Or in the British Empire, the British government in London governed a diverse periphery that spanned the globe. In essence then, the empire is an entity in which there is an inherent power imbalance between the metropole and the periphery as well as a racial and national subordination. In the Soviet Union, such a power imbalance existed between the Russian-dominated center in Moscow and the highly diverse periphery although in theory this imbalance had been erased by the constitutionally mandated federal structure.

\section{Defining Decolonization}

Modern empires typically end through a process of decolonization. At face value, the concept of decolonization appears simple: it is the process by which an empire loses control over its territories or the periphery breaks free from the metropole's hegemony. As a result, the empire dissolves and the formerly colonized peoples create independent states. However, while this is the basic idea of decolonization, modern history has shown that decolonization can take 
place in a variety of ways and a number of historians have presented theories as to how this process takes shape.

In his book Decolonization in Africa, John D. Hargreaves defines decolonization as "measures intended eventually to terminate formal political control over colonial territories and to replace it by some new relationship." 9 This new relationship did not necessarily mean independence for the colonized territory, but the policies pursued by powers such as Britain and France beginning as early as the 1930s ultimately led to independence in the 1950s and 1960s.

Where authors have attempted to deconstruct decolonization into an identifiable and definable process, intent on the part of the imperialist power is a common thread. A few have likened this intent to decisions taken by executives in the business world. For example, "Decolonization, it is argued, is best understood in terms of contemporary business thinking, i.e. a conscious design on the part of managers to 'downsize', 'restructure', and 're-engineer' the imperial project."10 Above all, however, the decolonization process has often begun as a conscious effort by the imperial power to reform and restructure the empire. The idea is to place the colonized peoples on a somewhat more equal footing with the imperial power in order to maintain the imperial power's control of the colonized territories. In the case of Britain and France especially, these efforts typically backfired, particularly in Africa, thus ultimately resulting in independence for the colonized and the collapse of vast empires.

If decolonization is therefore a planned process, some historians and theorists have found sinister purposes for it. Decolonization, when initiated from above, can actually come with the intent to maintain elements of the empire. In the case of Britain's efforts in Africa, neo-Marxist theorists have viewed "decolonization as a pre-emptive strategy in which British governments, serving the interests of metropolitan capitalism, cynically anticipated and outmanoeuvred 
colonial radicalism by prematurely transferring political sovereignty to 'moderate' nationalists." Another view holds that beginning as early as the 1850 s a "'gentlemanly capitalist' alliance" formed between financiers in London and policymakers at Whitehall and Westminster in order to develop the sterling area. By the 1950s, this alliance had allegedly hatched a plan for the "smooth dismantling of empire in which the City's interests were largely preserved."11 Thus decolonization may be viewed in many cases as a transition from formal empire to informal empire in which the imperial power still exercises political and/or economic influence in the former colony. In some respects, this may be considered "empire on the cheap" as it preserves the economic ties of empire without the expense (and the hassle) involved in maintaining the formal bonds of empire.

Robin Winks has argued that if decolonization is indeed planned by the imperial power, then that power controlled, often through the use of force resulting in war, the entire process the colonized did not win their independence; it was granted to them by their colonizer on the colonizer's terms. This therefore means that in cases where the decolonization process was planned by the imperial power, once independence is achieved, an informal empire remains. ${ }^{12}$ Therefore, as William R. Louis and Ronald Robinson have argued, decolonization, despite common assumptions, "is not necessarily a sign of metropolitan weakness." Louis and Robinson maintain that Canada, Australia, and South Africa gained virtual independence while Britain was at her strongest before 1914, yet when Britain was much weaker between the world wars, her empire had reached its greatest extent. For Louis and Robinson, decolonization in the British Empire after World War II was not necessarily a retreat from empire driven solely by extreme metropolitan weakness (although this did play a role), rather it was part of a larger process of the forging of the Anglo-American coalition to contain the Soviet Union. ${ }^{13}$ Thus, in the case of 
Britain, according to Louis and Robinson, decolonization at least in part meant transforming the formal empire into an informal Anglo-American empire to safeguard the Third World from Soviet infiltration.

After World War II, Britain retreated from its colonies in India and Palestine, but sought to strengthen its control over its African colonies as well as over Malaya. This re-assertion of imperial control in Africa and Malaya has been termed the second colonial occupation. As Joseph Hodge explains, some British political leaders after the war envisioned "an imperial renaissance, with the boundaries of the overseas empire simply shifted further to the east in Asia and into the Middle East and Africa as well." 14 However, the war left Britain bankrupt and reliant upon American loans to stay afloat financially. This created a sterling crisis and thus "the Labour government looked to empire for salvation, impressing on individual administrations the need to intensify the exploitation of imperial resources in an effort to use the colonies to earn dollars by exporting to the United States, and save dollars through substitution of imports from the dollar area to Britain." ${ }^{\prime 15}$ As a result, Britain encouraged the local colonial administrations in Africa to intensify economic development and to modernize colonial administration to maximize the empire's economic profitability. Such policies led to the disastrous groundnut scheme in East Africa which devastated the local environment, damaged local agriculture, and most importantly antagonized the peoples of Tanganyika leading to rising nationalism and thus the further development of the decolonization process. Similar interests led to renewed imperialist policies in Malaya as well. ${ }^{16}$ Britain allowed neighboring Burma to leave the empire soon after Indian independence as "Burma's rice, oil, and timber were valuable but far less significant dollar-earners" than Malaya's tin and rubber resources. In Malaya, then, "the British envisaged a prolonged period of colonial rule during which their priorities would be administrative 
efficiency, economic rehabilitation, and the creation of a multi-racial nation." ${ }^{17}$ As in East Africa, Britain's second colonial occupation of Malaya triggered nationalist opposition to colonial rule and hastened the decolonization process there. The second colonial occupation and its focus on the retrenchment of imperial power in Africa and Malaya thus failed. However, the second colonial occupation represented an effort to reform the British Empire in Africa and Malaya with modernization of the local colonial administrations and of local economies as important components. ${ }^{18}$ In India, the slowness of democratic reforms and the reluctance of the British to relinquish control met with resistance from the peoples of India, which, along with conflict between Hindus and Muslims quickly forced the British out in 1947.

Like the post-war British Empire, France also sought to reform its empire largely for economic reasons. With the onset of the Great Depression in 1930, officials in France began to change the way they viewed their African empire. Since 1900, Paris had operated its empire on the principle that the colonies should pay for themselves through the export of raw materials. Metropolitan France should bear little, if any, cost for maintaining its colonies. The severe economic downturn of the Depression made this impossible as markets for the colonies' materials dried up. This led the French government in the 1930s to search for ways of generating revenue in its colonies in Africa. Naturally, the most immediate and logical way of acquiring such revenue was to raise taxes on the colonies while at the same time cutting expenditures on services such as health care and education in the colonies. Schemes to take further economic advantage of the colonies emerged as well, including stepping up the already existing procedure of forcing African peasants to work free of charge on imperial projects. As can be expected, these policies in the 1930s generated increasing resentment on the part of France's African 
subjects. A growing African political consciousness emerged among the French-educated African elite, which was further emboldened by the Italian invasion of Ethiopia in $1935 .{ }^{19}$ Tony Chafer argues that the Great Depression and the coming to power in France of the Popular Front in 1936 convinced many in Paris and in French Africa that a new approach should be taken to governing the empire. The Popular Front "conceived of colonialism as a work of collective solidarity, a partnership from which both the colonizer and the colonized could benefit, not only in material but also in moral terms." Moreover, in contradiction to right-wing colonialism, "left colonialism was presented as modernizing, progressive, and generous."20 Thus, the Popular Front initiated several reforms that included press freedom, the right for Africans to join trade unions, and certain exemptions from the indigenat - a process by which French administrators could imprison or fine Africans without a trial. These reforms were shortlived however. Within two years, the Popular Front disintegrated and then World War II intervened to divert attention away from any grand reforming designs for the empire. But Chafer argues that despite its short duration, the Popular Front left an important legacy in the empire that would ultimately help contribute to eventual decolonization. To begin with, the Popular Front's relative enthusiasm for liberalizing the imperial system in effect made the French Left active participants in and ardent supporters of the imperial project. More significantly, though, is that the Popular Front's efforts to reform the empire made an already existing contradiction even more glaringly apparent - that "French colonialism could be generous, humane and civilizing" yet it had an "in-built tendency to authoritarianism.",21

The first sweeping reform attempted in France's African empire came with the Brazzaville Conference in 1944. Henri Laurentie, Director of Political Affairs in the Commissariat aux Colonies in Algiers, prepared the Conference's Program. In the Program, 
Laurentie recommended the transformation of France's African empire into a federation "to be governed by a new federal assembly with elected representatives from the metropole and each of the associated territories. Within the federation, the colonies would enjoy considerable economic and administrative freedom, and local elected assemblies would afford Africans the opportunity to become involved in the management of their own affairs." Laurentie added that eventual selfgovernment for France's African empire could be possible, but not in the foreseeable future. ${ }^{22}$ In the end, the Brazzaville Conference - which no Africans attended - rejected Laurentie's idea of federation, but it did adopt some recommendations aimed at ending the greatest excesses of French colonial rule and at modernizing local African societies similar to those modernizing policies adopted by the British. Thus, since the 1930s, except for the interruption imposed by the wartime Vichy regime, the impetus for reform existed in Paris. But the goal always was to retain the empire. Interestingly, even the staunchly anti-imperialist French Communists opposed independence for France's African colonies "partly out of a belief that they were not yet ready for national independence and partly because they believed that the effect of independence would be to abandon the colonies to the reactionary yoke of American imperialism."23 The French Communists apparently believed that national identity and economic development had not yet sufficiently developed among the Africans, therefore Africans in France's empire may have been viewed by French Communists in ways similar to Bolshevik analyses of the peoples of Central Asia.

Reforms did finally come to the French Empire after World War II. Under the postwar leadership of Charles de Gaulle, the French Empire was transformed into the French Union - a quasi-federal structure meant to preserve French unity and more importantly to preserve the French Empire. Under this arrangement, certain “Associated States” such as Morocco, Tunisia, 
and Indo-China would enjoy some autonomy while the sub-Saharan African colonies would become "Overseas Territories" within the French Republic. ${ }^{24}$ Ultimately, this arrangement allowed the African colonies to elect representatives to the French Assembly in Paris, albeit within the confines of a highly restricted electorate that favored French settlers and administrators. Nevertheless, it did allow some African participation in the French political process, which, according to Chafer, actually had the effect of acting "as something of a disincentive for them to press for immediate independence" because some African leaders gained a "stake in the maintenance of the [imperial] link." ${ }^{25}$ Despite this disincentive, the wartime experience of helping to support the French war effort combined with the reforms culminating in the French Union ultimately contributed to the decolonization of France's African empire in the 1950s and 1960s. Bitter wars in Vietnam and Algeria also forced France to quit its empire in those colonies. Thus, decolonization in the French Empire was never intended by Paris, but came in many ways as a result of reforms undertaken in the empire.

What then explains the British and French efforts to reform their respective empires? In both cases, anti-imperial movements among the colonized peoples along with the respective civilizing missions of both empires and, in the case of Britain postwar economic problems, combined with pressures from the anti-imperialist United States and the Soviet Union propelled them to reform their empires. In the case of Britain, the desire after World War II was the second colonial occupation of Africa and Malaya and "to set colonial rule in Africa on a proper footing, to engineer the late colonial state on surer foundations" motivated by "high-minded liberalism, the pragmatic desire to improve the management of imperial resources..."26 Britain wished to spread liberal economics along with the Westminster model of government that would evolve "over at least a generation from the local base upwards towards eventual self- 
government. ${ }^{27}$ France had a similar civilizing mission that received renewed impetus from the Popular Front as explained above.

To summarize, decolonization is a process that begins often with planned reforms to the imperial structure that entails a reconstruction of the ties between the imperial power and its colonies. This plan either envisions eventual independence for the colonies as in the case of Britain, or it intends to restructure the imperial order in an effort to place the colonies on a more equal footing with the metropole, as was the case with France, which nevertheless ended with independence because of rising nationalism and international pressure. But decolonization need not begin with a plan for reform. A long war in Vietnam, for example, expelled the French before reforms could be implemented. Similar events expelled the French from Algeria. Thus, decolonization can occur in several different ways and involves many different processes. However, for the purposes of this study, decolonization can be defined this way: it is a process that begins either within the imperial state itself or "from below" by the colonized peoples or through a combination of both, often as a result of planned reforms from the imperial center. This process can be a conscious effort by the imperial power to divest itself of its colonies or it can be a conscious effort to retain the empire. Whatever the motive, the process, either deliberately or unintentionally, results in the end of the empire as the colonized peoples achieve political independence typically through a tandem of indigenous nationalism and attempts by the imperial center to effect reform. The end result, regardless of the path taken, is independence for the colonized peoples and the dissolution of the empire. 


\section{Comparing the Soviet Empire with the British and French Empires}

British and French imperial policies shared several similarities with Soviet imperial policies. While direct comparisons will be made in later chapters as they become relevant to Soviet policies, this section will outline the main areas in which British and French imperial policies resembled certain aspects of Soviet nationality policy.

The British sought to balance the competing issue of tolerance for native languages with English as the official language. The debate on the use of language in education in Britain's African colonies during the 1920s serves as a good example illustrating this point. In 1923, Whitehall formed the Advisory Committee on Native Education in British Tropical Africa whose purpose was to advise the Secretary of State for the Colonies. Central to the Committee's work was the issue of which languages should be used in the schools of Britain's colonies in Tropical Africa. The debate centered on whether to use English or the vernacular languages as the medium of instruction in the schools. Hanns Vischer, the Secretary of the Committee and the former Director of Education in Northern Nigeria wrote a memorandum in 1925 in which he "highlighted the value of the mother tongue as the medium of instruction, especially in the early years of schooling." Vischer also argued that "By taking away a people's language we cripple or destroy its soul and kill its mental individuality...If the African is to keep and to develop his own soul and is to become a separate personality, his education must not begin by inoculating him with a foreign civilization...the vernacular...is the vessel in which the whole national life is

contained and through which it finds expression." 28 Vischer's memorandum met with opposition and support among the colonial education officials in Africa. The Gold Coast approved of Vischer's memorandum in principle, but rejected it on the grounds that teaching English in the elementary schools was already well-entrenched and that to change to the vernacular would be 
too inconvenient. Similarly, officials in the Gambia rejected Vischer's proposals as no textbooks printed in the vernacular languages existed and that as a result, education in the vernacular would cut students off from "modern thought." The acting governor of Sierra Leone "suggested that English was the only practical lingua franca for which there was overwhelming African support..."29 Finally, "Most colonial educators were forever mindful in the 1920s of the potentially disruptive impact of European civilization on African tribal life and equally anxious to mitigate the worst excesses of economic exploitation. But Africans were not passive recipients of change. They were equally attracted to the material benefits of western civilization and soon realized the importance of knowing how to speak and write in English." ${ }^{30}$ Thus, British colonial officials in Africa were aware of the importance of language in the schools and the effects it had on modernization in society and on cultural development.

Second, there was a tendency toward centralization in both the French Empire and in the Soviet Empire under Brezhnev. As Chapter Four will show, one of the primary components of Brezhnev's doctrine of Developed Socialism involved the reassertion of Moscow's control over the Soviet periphery through the promotion of Russian as a lingua franca and culminating in the new Soviet Constitution ratified in 1977. French imperial policies were generally assimilationist in nature as "the preferred French administrative model was one of direct rule derived from French conceptions of a strong, centralizing state and the almost sacred doctrine of the 'One and Indivisible Republic', and the impact of principles derived from these was felt at every level.,31 de Gaulle's Commissioner of Colonies even remarked to the Brazzaville Conference that the aim of the French Empire was to "transform French Africans into African Frenchmen." This aim is similar to Soviet policies under Brezhnev that touted the eventual development of the Soviet nation that essentially was Russian at its core. 
Third, Soviet policies and British imperial policies sought to control nationalism in various ways. In the Soviet case, nationality policy aimed at fostering the development of nonRussian national identities but within a proper socialist context and in such a way that did not challenge Soviet rule. In Nigeria, Britain sought to control radical nationalism there after 1945 as the colonial administration in Nigeria equated the growth of nationalism with the spread of Communism in colonial Africa. As a result, British officials in Nigeria "effectively checkmated the growth of radicals in Nigeria's nationalism by proscribing the Zikist Movement in 1950; imprisoning the labour leaders ... and discouraging the youths from being associated with radical youth bodies outside Nigeria.",32

Fourth, nationality policy across the Soviet Union was not uniform. Indeed, as later chapters will show, there was regional diversity in terms of applying nationality policy. In essence, Moscow retained tighter control over Ukraine and the other western republics while it allowed for more leeway in Central Asia with policies toward the Caucasus republics falling in between. British imperial policy also was not uniform. British policies wavered between direct rule and indirect rule sometimes even within colonies, such as India. For example, "British India was 'formal empire' (colonies under direct imperial rule) comprised of seven to seventeen colonial province during 1858-1947, each headed by a British governor, lieutenant governor, or chief commissioner. Princely India was 'informal empire' ... comprised of over 600 native states and tribal territories, each with its own ruler or chief overseen by a British resident or agent." 33 While Soviet policies did not vary as widely as British imperial rule in India or elsewhere in the British Empire, there is a strong similarity between the Soviet Empire and the British Empire in that for various reasons, neither empire applied imperialism uniformly. 
Finally, as Chapter Six will show, the Soviet Union pursued its own "second colonial occupation" in the form of Brezhnev's doctrine of Developed Socialism as well as through the Brezhnev leadership's emphasis on the scientific-technological revolution and grandiose projects such as the Baikal-Amur Railway (BAM) and the reversal of Siberian rivers to provide water for cotton production in the Central Asian republics.

As for the decolonization process, it was both planned and unplanned by the Soviet leadership. As will be discussed below, Lenin and the early Bolshevik regime undertook measures designed to begin a decolonization process in the former Russian Empire. Bolshevik measures to control nationalism among the peoples of the former empire resulted in the beginnings of a decolonization process initiated from above. Yet, the early Bolsheviks and their successors never intended to grant most of the peoples of the former Russian Empire full independence. As will be explained, Soviet nationality policy did anticipate a measure of decolonization, but Lenin and his successors believed that once the non-Russians of the Soviet Union had achieved greater equality, they would not desire to complete the decolonization process by seeking independence. Despite efforts later on to rein in elements of this planned decolonization, the process could not be stopped entirely, which ultimately helps lead to the growth of the decolonization process by the 1970 s.

\section{The Imperial Inheritance}

The Soviet Empire was a new form of empire due to its ideological basis. Bolshevik ideology soundly denounced imperialism in all of its forms as well as nationalism. But nevertheless, Bolshevik policies laid the foundation for the creation of the Soviet Empire. Soviet imperialism developed for several reasons: first, the historical legacy of the Tsarist empire, 
second, the Bolsheviks' own early nationalities policies which were meant to control the forces of nationalism, and third, Bolshevik ideas on the nation, nationalism, and imperialism led them to conclusions about these phenomena that differed fundamentally from Western non-Marxist interpretations. What follows is a discussion of the first two points - the historical legacy and early Bolshevik nationalities policies, while the third point will be examined in detail in Chapter Two in order to demonstrate why in the Soviet mind the Soviet Union could not have been imperialistic despite the fact that Soviet nationality policies were imperialistic.

In many respects, the Soviet Union became an empire because it inherited imperialist characteristics from its Tsarist predecessor. In this section, I will briefly outline the basic features of the pre-Soviet Russian Empire and then discuss in greater detail Soviet nationality policies that in some cases continued previous tsarist policies and in others developed new approaches to the nationality question. The continuities between tsarist and Soviet policies in light of the precedents of the British and French empires discussed above will clearly indicate that the Soviet Union functioned as an empire, albeit in a new form.

From Ivan III's conquest of Novgorod in 1478 to the February 1917 Revolution that finally toppled the monarchy, the Russian Empire undertook an almost continuous process of expansion, which halted only when this expansion was blocked by coming into contact with another European empire or when loss of interest or revolution distracted the expansion process.

Glory provided the initial motivation for the earliest period of Russian expansion. In the $15^{\text {th }}$ and early $16^{\text {th }}$ centuries, in the wake of the collapse of the Byzantine Empire, Orthodox priests advanced the idea that Moscow, as inheritor of the Byzantine legacy, was the Third Rome - destined by God to advance Orthodox Christianity and to expand her power and influence in the east. Just as Byzantium had continued Rome's legacy in the East, Moscow was to do the 
same in the face of the onslaught of the "infidel" Turks. Andreas Kappeler, however, is careful to point out that while the Third Rome idea was useful for the Russian Church and for some early Russian nobles for its propaganda value, it did not serve as the primary motivation for Muscovy's tsars. Instead, Ivan III and his successors invoked the memory of the Riurikids to justify early Russian expansion. Kappeler explains that the "imperial ideology was not...based on the doctrine of 'Muscovy, the third Rome'... but on the emphasis placed on the development of Rus itself, of the Riurikid dynasty and its successful policy of expansion in the 'gathering of the lands of Rus." "34 Geoffrey Hosking agrees with Kappeler's assessment of the motivation behind early Russian expansion, but he places equal emphasis on the Third Rome idea. Hosking explains that Ivan III claimed that in the $11^{\text {th }}$ century, a Byzantine emperor conferred the imperial crown on Vladimir Monomakh of Kiev, thus implying the imperial succession going back to Augustus. By marrying the niece of the last Byzantine emperor, Ivan III thus inherited that imperial mandate. Therefore, according to Hosking, “the 'invention of tradition' implied that Muscovy had a natural right to reclaim all the territories which had at any time been ruled over by any of the princes of Rus." 35 Hosking adds that Russian expansion only stopped "when Russia fetches up against another power capable of offering effective resistance and of affording a stable and predictable frontier, so that further relations can be conducted on a diplomatic rather than a military footing." 36 Moreover, the "Gathering of the Lands of Rus"” idea provides precedent for later Soviet policies that emphasized the importance of the three main Slavic peoples of the Soviet Union - the Russians, Ukrainians and Byelorussians. On at least a subconscious level, the Soviet leaderships' less-tolerant attitudes toward any manifestations of Ukrainian or Byelorussian nationalism in later years can be seen as a remaining vestige from the Tsarist mindset. 
Kappeler and Hosking both focus on the development of the Russian Empire from Ivan III to Nicholas II, but they approach the subject from different perspectives. Kappeler analyzes the Russian Empire through a nationality approach by placing greater emphasis on tsarist nationality policies and the reactions from the non-Russians as a result of those polices. Meanwhile, Hosking writes his history largely through the perspective of the Russians themselves. His central argument is that the ways in which tsarist Russia approached statebuilding actually impeded the process of nation-building among the Russians. Tsarist policies worked against the construction of Russian national identity particularly through the suppression of nascent Russian nationalist movements in the $19^{\text {th }}$ century. Hosking's argument is flawed, however, in that tsarist policies themselves promoted Russian national identity, though they did resist the more radical elements of Russian nationalism. On the other hand, Kappeler argues that tsarist nationality policies in many ways fostered the development of nation building among the non-Russian peoples. Through these two different perspectives, we can learn much about the functioning of the Russian Empire, its expansion, its rationale, and its policies. As we will see, Soviet nationality policies had much the same effect - they hindered Russian national identity while promoting non-Russian national identity.

The "gathering of the lands of Rus" continued as a justification for expansion until at least the late $18^{\text {th }}$ century. Kappeler argues that Russia justified her part in the Partitions of Poland as a continuation of the reuniting of lands and peoples that once belonged to the medieval Russian state. But by this point, new motivations for expansion came into play. Beginning with Peter the Great's wars with Sweden and the Ottoman Empire, it can be argued that the quest for power played a larger role in pushing Russian expansion. Power and security certainly were concerns during the Polish partitions. Kappeler states that by the 1770s, Russia had long been 
interfering in the domestic politics of Poland in order to solidify Russia's standing as a great Eastern power as well as for security reasons - Russia's leaders felt threatened by Poland's liberal 1791 constitution and by nationalist revolts later in the decade. ${ }^{37}$ Nationalist revolts in Poland also can be described as an early development of a decolonization process within the Russian Empire. As will be discussed later in this chapter and in subsequent chapters, similar foreign policy concerns also influenced Soviet nationality policies, especially during the Brezhnev era. By 1800, then, Russian imperial expansion derived not solely from ideas of glory. Realist concerns were beginning to come to the fore.

As Russia continued its expansion into Central Asia and the Far East during the $19^{\text {th }}$ century, the "gathering of the lands of Rus" failed to be a realistic justification. As Kappeler explains, the American Civil War of the 1860s forced Russia's textile industry to seek new sources of cotton. As Russia began to industrialize, economic motivations increased in importance. Kappeler argues that cotton as well as the desire to control Central Asian trade routes in part to acquire "markets for Russian industrial products, which were difficult to sell in central and western Europe" helped to drive expansion into Central Asia. ${ }^{38}$

But Kappeler is careful to point out that economics was not the sole force driving continued expansion in the $19^{\text {th }}$ century. International power politics were probably far more influential. Russia's humiliating defeat in the Crimean War, Kappeler asserts, "had proved detrimental to the prestige of the elite, and especially of the military leadership, and made them look for various kinds of compensation. Thus it was suggested that Russia should demonstrate its imperial might in Asia and attain a position which equaled that of the western colonial powers. ${ }^{39}$ The developing Anglo-Russian rivalry over Central Asia helped fuel this spirit of competition with the European powers as exemplified by the Great Game. 
Similar realist concerns - economic, security, and power rivalry - also explain Russian activity in the Far East in the late $19^{\text {th }}$ and early $20^{\text {th }}$ centuries. Construction of the TransSiberian Railroad prompted Russian interference in Chinese affairs as Russia desired control of Manchuria as a shorter route to Vladivostok. Japan's declaration of war on Russia halted these activities.

With expansion, of course, came contact with foreign peoples and the need to devise policies dealing with these peoples. Russia, like all other empires, did not have a single preexiting plan for nationality policies. At first, nationality policies were largely based on cooperation with native elites. Kappeler explains that pre-modern Russian policies centered on such cooperation and "a far-reaching retention of the status quo." The use of existing structures "was designed to guarantee a smooth transfer of power and to underpin Muscovite legitimacy.",40 This pragmatic approach was learned by Muscovite leaders in the $15^{\text {th }}$ and $16^{\text {th }}$ centuries as the best way to prevent resistance movements and to ensure the loyalty of new subjects. Russian imperial policies toward the newly-acquired Bashkir lands in the $16^{\text {th }}$ century is a case in point. When Russia first gained control of Bashkiria in the $16^{\text {th }}$ century, Russian rule there was relatively soft as the Russians left intact the Bashkir tribal structure. Indeed, "Russian authorities left the local affairs of the Bashkir tribes to the authority of the Bashkir elders (starshina)." In this early phase of Russian imperial control, so long as the Bashkirs paid their annual taxes to the Russian authorities, the Russians did not interfere in Bashkir affairs. ${ }^{41}$ Thus new elites, such as Tatar and Muslim landowning elites, were essentially co-opted into the Russian elite which was often accompanied by bestowing Russian nobility on these non-Russian elites. ${ }^{42}$

By the $18^{\text {th }}$ and $19^{\text {th }}$ centuries, this smooth transition approach had largely given way to coercion and colonization practices. The development of Russian national identity - 
Slavophilism and Pan-Slavism in particular - helped to drive Russian nationality policies toward a more hard-line approach toward non-Russians. In the $18^{\text {th }}$ century, according to Kappeler, "Russia adopted from the west a Eurocentric feeling of superiority towards Asia.",43

Increasingly, due in part to this Eurocentric attitude, Russian policy began to harden. Nicholas I and his ministers, for example, regarded Transcaucasia "as a colony inhabited by uncivilized Asiatics." ${ }^{44}$ As national movements increased in Russia through the $19^{\text {th }}$ century, nationalistinspired resistance movements developed as did an increasing sense of Russian national identity. Especially for those peoples who had at least a semblance of historical statehood - such as the Ukrainians with memories of the Cossack Hetmanate and the Poles who for centuries ruled a powerful kingdom - nationalist stirrings inspired them to seek the return of independence.

As these national movements grew, the Russian state adopted more strict policies to handle the nationality issue. Poland serves as the classic example of these changing attitudes. After Nicholas I won the title of King of Poland at the Congress of Vienna in 1815, he granted the new Polish Kingdom a quite liberal constitution. But numerous Polish uprisings and the growing sense of Russian national identity hardened St. Petersburg's policy toward the Poles. Even the reformist tsar Aleksandr II, according to Kappeler, decided after 1863 to pursue "the goal of solving the Polish question once and for all through repression and forced integration."45 After this point, Aleksandr II and his successors began concerted efforts to effect the "cultural and linguistic russification" of not only the Poles, but also the Ukrainians, Belorussians, and the Lithuanians. Alongside these policies, Hosking notes that the rise of Slavophilism contributed to more widespread anti-Semitism in the western third of the Russian Empire as the Slavophiles rejected all things western and alien to the purely Russian way of life. Overall then, as Kappeler and Hosking argue, the rising tide of national feeling among Russians and non-Russians alike 
resulted in a tendency toward harsher policies toward the non-Russian peoples of the empire throughout the $19^{\text {th }}$ century.

In light of the brief discussion above, glory, power, and economic concerns motivated the expansion of the Russian Empire. As the empire expanded, Russia had to find ways to deal with the peoples it incorporated into its territory. At first, the Russians relied on co-opting native elites to ensure a smooth transition and to preserve peace. Yet, as nationalism - both Russian and non-Russian - developed in the nineteenth century, tsarist nationality policies became more concrete and increasingly aimed to contain the forces of nationalism, largely through coercive measures.

\section{Building the Soviet Empire}

Because of their decidedly anti-imperialist and anti-nationalist worldview, the early Bolsheviks sought to re-make the old tsarist empire into a multinational workers' state focused on building socialism and then building communism while at the same time ending the national differences that had manifested themselves in the nineteenth century. In terms of nationality policy, Lenin and his colleagues hoped to promote the development of a new nationality - the Soviet nation - that would be internationalist in its worldview and be respectful of the many national cultures that existed in the new Soviet state. In the end, however, the Bolsheviks succeeded in remaking the old tsarist empire into a new Soviet, communist empire.

As I noted at the beginning of this chapter, I am not the first to propose that the Soviet Union was an empire. This idea has been mentioned by other historians, though most do not specifically explain why the Soviet Union became imperialist, which is where the present study places itself in the historiography. However, Terry Martin in his study The Affirmative Action 
Empire: Nations and Nationalism in the Soviet Union, 1923-1939 does develop the empire theme by analyzing the first two decades of Soviet nationality policies. In many respects, as will become clear in later chapters, I envision this study as an extension of Martin's work into the post-Stalin period, in particular the Brezhnev era.

Martin acknowledges that the Soviet Union was an empire, albeit one of a very different kind. He writes, "The Affirmative Action Empire was not a traditional empire. I am not aligning myself with those who now argue that the Soviet Union, as a result of its shared characteristics with other empires, can be classified in objective social science terms as an 'empire.' On the contrary, I am emphasizing its novelty.' Moreover, Martin observes that during the Cold War, Soviet detractors often called the Soviet Union an empire, whereas its supporters or the more neutral observers simply referred to it as a multinational state. ${ }^{46}$ Martin, however, takes a neutral stance on this issue - his book examines early Soviet nationality policies to demonstrate that the Soviet Union was an empire, only a new kind of empire that the world had not yet seen. I concur with Martin in that the Soviet Union constituted a novel type of empire, though I argue further that in addition to it being a new style of empire, it is an empire that emerged largely by historical accident and, as will be examined in Chapter Two, the Marxist-Leninist theories on nations, nationalism, and imperialism conditioned the Soviets to understand that their state could not be imperialist, which explains why Soviet nationality policies manifested themselves in the ways that they did. What follows is a brief overview of the ways in which the Bolsheviks worked to prevent the complete dissolution of the former tsarist empire and then a discussion of early Bolshevik nationality policy based largely on the works of Martin, Richard Pipes, Francine Hirsch, and Helene Carrere d'Encousse. This will serve to demonstrate that while Bolshevik ideology stressed internationalism, their policies often resulted 
in the preservation of empire because of historical legacies and realities encountered by the Bolsheviks in the 1920s.

By 1900 the forces of modern European nationalism had entered the Russian Empire. The Slavophile and Pan-Slav movements combined to form a conservative, and at times xenophobic, Russian national movement. In the non-Russian periphery, similar national movements emerged that began calling for separation from the Russian Empire. In 1900, for instance, the Revolutionary Ukrainian Party formed, the first Ukrainian nationalist party to call for independence from Russia. ${ }^{47}$ By 1917, nationalist or proto-nationalist movements had formed across the Russian Empire ranging from the Menshevik-dominated Georgian movement to the emergence of a nascent Azerbaijani national movement to pan-Muslim movements originating among the Tatars. Coinciding - and very often intermingling - with these national movements was Marxism in its various forms. In many of these national movements, in particular the RUP until its demise by 1905 and the Georgian national movement, Marxists moved freely, many of them either unaware or uncaring of the ideological opposition between Marxism and nationalism. But many Marxist theorists, both inside and outside of Russia, had already begun the theoretical acrobatics of trying to reconcile Marxism with nationalism.

Marx and Engels had denounced nationalism as a key characteristic of the capitalist era. Therefore, according to Marx and Engels, internationalism was to characterize the post-capitalist era; nationalism would disappear along with class antagonisms. This "orthodoxy" had been passed down to the second generation of European Marxists writing at the turn of the $20^{\text {th }}$ century. Foremost among these was the Polish Marxist Rosa Luxembourg. She adhered to Marxist orthodoxy, going so far as to oppose any kind of independence for Poland because her native land had become too economically intertwined with Russia, Germany, and Austria- 
Hungary. Moreover, Luxembourg argued that Russia's 1905 Constitution meant that Russia "ceased to be the bulwark of European absolutism" so therefore Poland should seek autonomy within a democratic Russian state. ${ }^{48}$ "Luxembourgism" thus became popular among many Eastern European Marxists as it opposed vigorously most forms of nationalist movements. ${ }^{49}$ Unfortunately for Eastern European Marxists, who were much more concerned with nationality issues than their Western European brethren due to the fact that multinational states and empires predominated in the east, Marxist theory was rather vague in terms of nationalism. Other than the observation that nationalities and nationalism were only temporary byproducts of capitalism, Marx was silent on how Communists should accommodate nationalism and nationalist movements. It was therefore left to Marx's descendants to work out the details.

Karl Kautsky, a Czech Marxist living in the Austrian Empire, argued that language is the main determinant in defining nationality. As capitalist economic growth intensifies, Kautsky argued, linguistic unification would follow, resulting ultimately in the development of a universal language. ${ }^{50}$ Fellow Austro-Marxists Karl Renner and Otto Bauer expanded upon Kautsky's ideas of the nation. Renner argued that nationality is a personal matter; it is not tied to territory so therefore the state "has an important role in fulfilling nationalist aspirations and balancing them with the state's needs. ${ }^{, 51}$ Bauer went even further. He argued that "a nation is not a temporary construct linked to a given period in the history of class struggle or economic development; it is rather a permanent phenomenon that predates capitalism and endures despite economic transformations, and in all probability it will survive." Therefore, according to Bauer, socialist revolution would give to the working class what the bourgeoisie had denied them - their country. Furthermore, after the revolution, intellectual progress would diffuse through all levels of society, thereby strengthening national differences. Bauer then concluded that Marx's 
internationalism is not a world in which national identity and nationalism would disappear, but instead is a world in which national differences persist with "proletarian internationalism ... promoting the harmonious coexistence of nationalities. ${ }^{, 52}$ The Austrian Marxists, therefore, were the first among Eastern European Marxists to propose a federal state in which the central government guaranteed the equality of all nationalities. The Bolsheviks in Russia, according to Helene Carrere d'Encausse, came late to the nationality issue. She states that for the Bolsheviks, the nationality issue "was a problem of the Russian political system - the problem of domination, by a great state, of peoples who were unable to protect their independence." ${ }^{53}$ Even after much theorizing and debate among the Bolsheviks during and after the Revolution, this most basic assessment of the nationality problem in Russia would form the foundation of early Soviet nationality policy - a policy that ironically led to a renewed empire.

Richard Pipes argues that Lenin sought a middle course between the Austro-Marxist realism of Renner and Bauer and the more utopian ideas of Luxembourg. According to Pipes, Lenin divided the world into three categories in terms of the national struggle. In the West, the national problem had been solved because capitalist development had led to the formation of tidy nation-states. In Eastern Europe, the nation-state was only in its infancy because of incomplete capitalist development. Finally, in the colonial world, nationalism had not even begun to penetrate due to the almost complete lack of capitalist development. The solution in Eastern Europe, then, called for the "large multinational empires...to transform themselves into national states, and the minor nationalities, incapable of attaining statehood, had to be swept out of their long isolation by the force of industrial development, and had to lose their identity through assimilation in the cities and factories with the industrially more advanced nationalities." Once Eastern Europe had attained to the level of economic development of Western Europe, it would 
have "lost its multinational character." From there, democracy would take over, "creating equal opportunities for all national groups, and...removing the main causes of national hostility, oppression and persecution" thereby paving "the road for a supra-national world system of government and an international culture of the socialist era."54 Through economic reasoning, Lenin thus charted a tenuous middle path between the revisionism of Renner and Bauer and the ultra-orthodoxy of Luxembourg.

As Pipes explains, Lenin got into some trouble over Point 9 of the Russian Social Democratic Labor Party's 1913 platform which promised the "right of all nations in the state to self-determination." Did this mean mere autonomy for those nations in the Russian Empire or did it mean the right to declare independence and secession from Russia? As Pipes points out, probably nobody who voted in favor of Point 9 interpreted this to mean the right of secession. But still, Lenin needed to find a way to justify the opposition against secession. According to Pipes, Lenin did indeed say to his fellow Marxists that Point 9 called for the support of independence for the non-Russian nations. But, Lenin argued, capitalist economic forces did not favor petty national states - similar to Luxembourg's reasoning, Lenin believed that as capitalism intensified in Eastern Europe, those nations would find it disadvantageous to seek separation from Russia. Moreover, Lenin reasoned, the mere promise of the right to secession would convince the minority nations that their long oppression had ended and they would then "cast off the suspicions which [Lenin] considered the primary cause of national movements." Finally, "Like most Marxists, [Lenin] desired the eventual transformation of the Russian Empire into a national state, in which the minorities would assimilate and adopt the Russian tongue." Such assimilation, of course, would be voluntary. ${ }^{55}$ 
On the eve of the 1917 Revolution, Lenin envisioned the continuation of the Russian Empire, but on a voluntary basis as economic forces and the end of oppression would coax most nationalities into staying. But instead of the re-invigorated Russian Empire continuing to exist as a multinational empire, Lenin believed that voluntary assimilation would transform the new socialist Russia into a Russian-speaking country in which the peoples shared a broad proletarian identity that transcended local national identities. At first, Lenin's approach to the nationality problem appears imperialistic: he opposed secession while still acknowledging it as a basic right, he initially opposed a federal solution to the nationality problem in favor of a single unitary state, and he assumed the non-Russians would assimilate into the Russian language (which implies at least some assimilation into Russian culture since language and culture are so intertwined). But appearances can be deceiving. At this stage, Lenin may be considered an incipient imperialist. First, he rejected the forced Russification of the minority nationalities. Secondly, he does not favor any continued expansion of the Russian Empire. Finally, and perhaps most importantly, Lenin's primary focus is on economics and revolution. The vast majority of his writings before and immediately following 1917 are concerned with the economic conditions of Russia and the capitalist West. Moreover, he is convinced that a global workers' revolution would take shape shortly after a Russian workers' revolution. International proletarianism would replace the shattered capitalist-nationalist world order.

But even before the Revolution, Lenin's thinking did begin to show some imperialist tendencies. As Encausse points out, Lenin confined the right to national self-determination only to those nations with a "geographical justification." For Lenin, "Secession was possible only for the nationalities living along the periphery, not for those enclosed in the interior." Instead, the 
interior nations were entitled to the guarantees of the Party Program which only prohibited national discrimination. ${ }^{56}$

The outbreak of the Civil War in 1918 gave further impetus to the already strengthening nationalist movements across the Russian Empire. Peoples across the former empire declared independence in the face of Bolshevik and White efforts to maintain the empire's territorial integrity. As soon as the Civil War began, Ukrainian nationalists formed the Ukrainian Central Rada in Kiev and declared Ukraine's independence. Similar movements took place in Transcaucasia, Poland, Finland, and in the Muslim East. Most of these movements were simply acting opportunistically - the collapse of the Russian state provided the opening for independence. While Poland, Finland, and the Baltic States were ultimately allowed to remain independent, the Bolsheviks re-conquered the rest of the former Russian Empire.

Revolutionary zeal was the primary motivator for the Bolsheviks to fight to keep the old Russia intact. Until his death in 1924, Lenin continued to believe that worldwide revolution was imminent, therefore it was paramount that the Bolsheviks prevent the disintegration of the Russian Empire. Territory lost could potentially be land lost to the revolution, or worse, lost to the capitalists. Moreover, the Bolsheviks believed that by fighting for the reintegration of the Russian Empire, they were actually fighting for the freedom of the peoples themselves. Indeed, the workers, peasants, and soldiers could only truly be free if they were able to participate in the revolution and follow the Bolsheviks along the path toward socialism.

Just behind revolutionary zeal was the quest for security. Emboldened by the workers' revolution, the Bolsheviks needed to secure their victory by holding onto as much territory as possible. This is not unlike Rome's conquest of Carthage that set Rome along its imperial path. Carthage was a potentially dangerous enemy that could threaten Rome's economic livelihood or 
take over Rome itself. In the throes of the Civil War, the Bolsheviks felt themselves to be encircled by hostile capitalist powers. Indeed, some of those capitalist-imperialist powers Britain, France, and the United States - sent armed forces to support the Whites. To secure Bolshevik victory, and above all to secure the proletarian revolution, necessitated the holding onto as much territory as possible.

Economics helps to explain Bolshevik actions as well. The loss of Ukraine, for example, would have meant the loss of valuable agricultural land as well as the coal and steel industries of the Donbass. Central Asia, as noted previously, was becoming increasingly valuable for its cotton monoculture, which skyrocketed under Soviet rule.

The rationale for the Bolsheviks' fight to keep as much of the Russian Empire intact thus resembled the rationale of other historical empires. Economics, according to Doyle and D.K. Fieldhouse, propelled the British to build their overseas empire. Later, security interests led the British to expand and to hold onto their empire. National glory as well as some economic interests drew France and Germany into the imperial game at the end of the $19^{\text {th }}$ century. For the Bolsheviks, similar motives prevailed. The key difference, however, was ideology. MarxismLeninism is chiefly an economic theory concerned with the transition first from capitalism to socialism and ultimately to a communist society. But it is also a modernizing, evolutionary theory. Through fostering the development of non-Russian national identities, the Bolsheviks believed that the nations of the new Soviet Union would eventually merge into an allencompassing Soviet identity, albeit with Russian characteristics. This is the foundation for Soviet imperialism.

Once the Bolsheviks had succeeded in retaining most of the territory of the former tsarist empire, they had to create the structures and policies to govern their new multinational state. 
Early Bolshevik nationalities policy centered on two primary premises: federalism and what later came to be known as korenizatsiia. It is in these formative stages of the Soviet Union that nationalities policies became imperialistic, thus creating the basic conditions and structures that later Soviet leaderships inherited.

One of the key components of early Bolshevik nationality policy is the federal structure developed for the new Soviet state. As noted above, Lenin favored the principle of national selfdetermination including the right of secession, while at the same time constructing a broad communist state. Therefore the removal of oppressive Russian policies toward the non-Russians would convince the non-Russians to remain and forsake independence. But how would such a multinational entity be structured? Lenin had consistently argued that nationalism is only a temporary phenomenon; the successful building of socialism would eradicate national feeling forever. Yet, in the immediate aftermath of the socialist revolution, it would still take time for national sentiments to wither away. The challenge for Lenin and the Bolsheviks, therefore, was to find a way to re-incorporate the far-flung territories and the myriad of peoples into a new Russian state that did away with Great Russian chauvinism while reassuring the non-Russian peoples that their national aspirations could be partly satisfied during this transitional period.

The idea of a federal state had been debated by Marxist theorists since the late $19^{\text {th }}$ century. As previously noted, the Austro-Marxists initially took the lead in this debate. Lenin, almost obsessively devoted to the principles of internationalism, at first rejected federalism as the solution to the national problem. He believed that only a single, unitary state could effectively mobilize the working class and begin the path to socialism. But it should also be made clear that Lenin did have realist tendencies. Evidence for this is Lenin's reversal of his stance on federalism. 
Gregory Gleason concludes that the Civil War, characterized in part by numerous drives for independence among the non-Russian peoples, convinced Lenin "that the yearning for voice and representation of the regions was a political resource to be exploited even at the cost of compromising his principled objections to federal arrangements. ${ }^{, 57}$ It was simply politically expedient for Lenin to acquiesce, at least superficially, to the demands of the non-Russians thereby lending his support for some kind of federal arrangement. But, as Gleason argues, Lenin still maintained his stance in favor of a unitary state as he envisioned federalism to be, like nationalism, only transitory in nature; federalism to Lenin was only a means to an end intended as a temporary measure to allay the fears and desires of the non-Russian nations.

But more than serving as a temporary fix for the nationality issue, Leninist nationality policy - the establishment of a federal state based on national-territorial components - was always intended by Lenin to be a temporary concession. Socialism by its very nature, according to Lenin, is a powerfully integrative force that, in Lenin's words, "facilitates and greatly speeds the rapprochement (sblizhenie) and fusion (sliianie) of nations." ${ }^{\text {"58 }}$ Ultimately, as socialism progressed, all nations would fuse into a single a-national class. Later, Stalin would alter the goal of Leninist nationality policy to mean the eventual fusing of all nations into a new Soviet national identity.

Fresh from victory in the Civil War and armed with Leninist nationality policy, the Bolsheviks set out in the 1920s to construct the new federally-structured Union of Soviet Socialist Republics. Debate quickly ensued as to how federal this new state should be as well as regarding the role Russians would play in this new federalized proletarian state. Lenin and Stalin were the two primary participants in this debate. Lenin favored the formation of a decidedly non-ethnic federation to be called the Union of Soviet Socialist Republics whereas Stalin initially 
proposed re-integrating the parts of the former empire into a new Russian Soviet Republic. The prominent Muslim Communist Sultan Galiev proposed that all nationalities, including the smaller ones, should become equal members of the USSR. Stalin countered this proposal, warning against the creation of creating a purely ethnic Russian state that, Stalin feared, would come to dominate the new union thereby hampering efforts to end Russian domination. In the end a compromise was reached. Geoffrey Hosking suggests that the December 1922 constitution that formally created the Soviet Union "was Leninist in form: that is to say, it was formally federal, and the new state, the Union of Soviet Socialist Republics, was not named after Russia. All the same, the content of the constitution was unmistakably Stalinist." It called for the creation of the Russian Soviet Federated Socialist Republic, which was not purely ethnically Russian as Stalin had warned against. Instead it comprised several smaller nationalities each with their own autonomous units within the overarching RSFSR. ${ }^{59}$ The large peripherallylocated nationalities such as the Ukrainians and Byelorussians were given their own Union Republics, theoretically equal to the Russians. The federal system seemed to solve the nationality problem.

Although officially the new Soviet Union had a federal structure and provided the major nationalities with their own nation-states, in reality centralizing tendencies worked to counterbalance the decentralizing forces of federalism. Adhering to Leninist democratic centralism, the Communist Party of the Soviet Union (CPSU), maintained tight control over the individual Communist parties of the various republics. In practice, the individual republic parties were only branches of the Moscow-based CPSU. In addition, issues relating to the military, foreign affairs, and economic policies remained fully within the purview of the allUnion government in Moscow. Because Russians dominated the CPSU in terms of membership 
as well as in the higher party echelons, the Soviet Union, like its predecessor, remained essentially under Russian rule. Despite the federal structure and promises of autonomy for the non-Russian peoples, the Soviet Union retained the center-periphery relationship of the former tsarist empire. Russian officials in Moscow still viewed the non-Russian borderlands through a colonial lens. The Bolsheviks, in spite of their rhetoric and of their best intentions, could not shake off the trappings of empire.

Perhaps most striking of the early Soviet efforts to engineer internationalism came with the conscientious efforts used to draw the borders between the Union Republics. In her book Empire of Nations: Ethnographic Knowledge and the Making of the Soviet Union, Francine Hirsch explores in-depth the ways in which the early Soviet regime made comprehensive use of ethnographic and anthropological data to draw the borders of the Union Republics in Central Asia and in the process "went about changing the individual and group identities of the population of the former Russian Empire. ${ }^{, 60}$ Hirsch's premise is that during the 1920s and 1930s, the Soviet regime used data collected from ethnographers and anthropologists to compile censuses, delimitate borders, and for general educational purposes in order to develop what Hirsch terms "state-sponsored evolutionism", which according to Hirsch, served as the "Soviet version of the civilizing mission" grounded in Marxist and anthropological theories on the development of nations. ${ }^{61}$ State-sponsored evolutionism was "premised on the belief that 'primordial' ethnic groups were the building blocks of nationalities and on the assumption that the state could intervene in the natural process of development and 'construct' modern nations." "62 These modern nations would then embark on a process of "double assimilation" in which a diverse population would assimilate "into nationality categories and, simultaneously, the assimilation of these nationally categorized groups into the Soviet state and society." 63 
Closely related to the federal structure adopted for the new Soviet state is the policy of korenizatsiia devised and carried out through the 1920s and early 1930s. Terry Martin's Affirmative Action Empire provides a detailed analysis of korenizatsiia and concludes that this policy produced what Martin calls the world's first affirmative action empire. In other words, Martin argues that korenizatsiia promoted non-Russian native elites in their respective republics as well as non-Russian languages and cultures, often at the expense of the Russians themselves. Ultimately, Martin maintains, korenizatsiia was scaled back as it "was generally popular with non-Russians, but it encountered unexpectedly fierce resistance from a variety of influential groups: urban workers (who were usually Russian speakers), Russians and russified titular nationals in the party and state bureaucracies, industrial specialists, and the filials of all-union enterprises. ${ }^{, 64}$

Korenizatsiia as a policy focused on promoting the non-Russian nationalities to place them on an equal footing with the Russians, all the while promoting the concept of internationalism among the working classes. Martin states that two resolutions passed in 1923 gave birth to the policy of korenizatsiia in that "In each national territory, the language of the titular nationality was to be established as the official state language." In addition, "National elites were to be trained and promoted into positions of leadership in the party, government, industry, and schools of each national territory." ${ }^{, 65}$ Ultimately, such policies were to apply not only to the Union Republics established in pursuit of federalist policies, but to all levels of national autonomy, all the way down to the local soviet level.

The term korenizatsiia is most often translated as "nativization" or "indigenization." Yet, as Martin points out, the Bolsheviks did not begin using this term until several years after these policies had been enacted. More importantly, Martin states that "The coining of the word 
korenizatsiia was part of the Bolsheviks' decolonizing rhetoric..."66 Thus, the intent of korenizatsiia was actually to foster the sense that non-Russian peoples no longer belonged to an empire but were now voluntary members of a multinational state where they could develop their own national identities within the Soviet Union. It was also intended as a means to control nationalism. Although the Bolsheviks through korenizatsiia publicly promoted the ideal of national self-determination, Martin states that because the Bolsheviks viewed nationalism as a bourgeois ploy to trick and deceive the working masses, they "remained highly suspicious of national self-determination, even after they adopted a policy explicitly designed to encourage it. ${ }^{, 67}$ Therefore, whereas the federal structure of the Soviet state gave the largest nationalities of the Soviet Union at least the semblance of their own nation-states and the Bolsheviks through korenizatsiia promoted non-Russian national identities and cultures, the real intent all along was to place tight controls over the extent of the development of national identities and cultures. Thus, the decolonization process sponsored by the Bolsheviks in actuality constituted a more limited form of imperialism. This new form of imperialism would intensify during the Stalin period, relax a little under Khrushchev, and re-intensify during the Brezhnev era. In the end, the Soviet regime could never reverse the decolonization process set in motion by the Bolsheviks in the 1920s.

Martin makes two other observations that are crucial to understanding not only the early Soviet period that he focuses on in his book, but continue to have ramifications throughout the entire breadth of Soviet history as will be discussed in later chapters. First, Martin argues that foreign policy concerns had some influence on the development of korenizatsiia policies. He calls this the Piedmont Principle and identifies it as one of several components of early Soviet nationalities policy. Martin writes that "Already in November 1917, Lenin and Stalin issued an 
'Appeal to all Muslim Toilers of Russia and the East,' which promised to end imperial exploitation within the former Russian empire and called on Muslims outside Russia to overthrow their colonial masters. This linkage between domestic nationalities policy and foreign policy goals in the east was quite common during the civil war period." Moreover, the 1921 Treaty of Riga, which established the border between Poland and the new Soviet state, meant that millions of Ukrainians and Byelorussians now found themselves living in Poland, separated from their co-nationals in the Soviet Union. Martin argues that this arrangement motivated the Bolsheviks to enact korenizatsiia in the western regions of their country as "It was hoped that an ostentatiously generous treatment of those nationalities within the Soviet Union would attract their ethnic brethren in Poland, Finland, and Romania." Martin is careful to point out, however, that such foreign policy goals never acted as a primary motivating factor in developing nationality policy; it was only a potentially beneficial side-effect of such policies. This fact notwithstanding, it does establish a precedent which will be evident in the Brezhnev era. As Chapter Three will make clear, Cold War concerns influenced Soviet nationality policies, in essence in part helping to motivate the Brezhnev leadership to be less tolerant of nationalist manifestations in the Western Soviet Union while being a bit more tolerant of such manifestations in the Central Asian Soviet Union. The foreign policy component also promoted regional diversity in nationality policy.

As indicated at the beginning of this chapter, by the Brezhnev era, at least four regional variations can be discerned in regards to nationalities policy. Based on the works of Martin and Andreas Kappeler, the existence of these regional variations had deep historical roots. Kappeler notes that in the nineteenth century, tsarist nationality policies were not uniform; while they tended in general toward increasing Russification and integration, these policies were applied 
differently in different regions and among different peoples. For example, Kappeler states that tsarist policy focused on integrating some peoples, while segregating others such as the nomadic peoples of Siberia, sedentary Muslims in Central Asia, and the Jews. Moreover, linguistic policies were more strict in some areas of the West and South such as Poland after 1863 and Georgia. At the same time, Kappeler argues that tsarist authorities worked to integrate the Christian peoples of Transcaucasia (the Georgians and Armenians) by pursuing Russification language policies and by appointing Russians as the local church leaders, whereas they largely had an ambivalent attitude to the many Muslim peoples of this region. ${ }^{68}$ Indeed, tsarist policies in general were ambivalent toward Muslims, a characteristic that can be seen in the Brezhnev era as well.

Martin argues that delineations similar to those explained by Kappeler also existed in the early years of the Soviet Union. He argues that while korenizatsiia policies applied to all nonRussians of the Soviet Union, "Nevertheless, the Soviet government did divide its population into two broad and traditional categories: eastern and western nationalities." East and West, Martin explains, did not necessarily mean east and west in geographic terms, instead, these referred to the perceived levels of development of the respective peoples. Culturally advanced peoples (like the Russians, Ukrainians, and Jews) were considered Western, while "culturally backward peoples" such as those of Central Asia were considered eastern. Martin continues by stating that "After considerable debate, the vast majority of Soviet nationalities were judged culturally backward. Of the Soviet Union's large titular nationalities, only the Russians, Ukrainians, Georgians, Armenians, Jews, and Germans were deemed 'advanced' and were grouped together as western nationalities. ${ }^{.69}$ Finally, Martin points out that while korenizatsiia policies were intended for both western and eastern peoples, "there were important differences in 
implementation." In the East where there were few educated national elites, the focus was on affirmative action policies in education and hiring in order to create a native national elite. In the West, on the other hand, native national elites already existed so the focus instead was on promoting the national languages - linguistic korenizatsiia. ${ }^{70}$ Therefore, foreign policy concerns did have some influence on Soviet nationality policies and the development of regional diversity in terms of nationality policy had long historical precedent going back to tsarist times. As Chapter Three will reveal, these currents continued to run in the Brezhnev era, albeit in slightly altered forms.

Despite the fact that korenizatsiia policies were in part intended to begin a decolonization process, albeit tightly controlled, Martin and others state that Lenin and his colleagues were careful to avoid the trappings of overt empire. Martin notes that "Lenin and Stalin understood very well the danger of being labeled an empire in the age of nationalism. In fact, here lies the real connection between the Soviet Union's national constitution and the collapse of the Habsburg and Ottoman empires." He adds that the collapse of the Habsburg Empire in particular "made an enormous impression on Lenin and Stalin, who viewed it as an object lesson in the danger of being perceived by their population as an empire." Thus, according to Martin, "the Soviet Union became the first multiethnic state in world history to define itself as an antiimperialist state." For Martin, the strong desire by Lenin and Stalin to avoid the empire label motivated both the formation of what Martin calls the Affirmative Action Empire and the choice to call the new state the Soviet Union rather than something containing the word "Russia". 71

The aim of early Soviet nationality policy was to develop national identities among the peoples who had not yet formed such identities while, for those peoples who had already developed national identities, Soviet policies were designed to root out chauvinistic attitudes in 
favor of more internationalist viewpoints. In all cases, national identities were either to be formed or be changed into a socialist content. Ultimately, Soviet nationality policies were intended to lead to a new "Soviet" identity.

As a result of these basic aims, policies in the 1920s produced some positive results. Bolshevik linguists set out to devise alphabets for those languages that lacked a literary past. Often these new alphabets were Latin based. Education policies called for minority nationalities to be taught in their native languages. Local cadres were recruited to serve in local party and government posts. Finally, the new regime made conscious efforts to ensure that each nationality - even down to the smallest peoples - had their own local soviets to protect their unique interests and to counteract any perceived chauvinism displayed by the local majority nationality whether it be Russian or non-Russian. Through the 1920s, then, it appeared as though the new Soviet regime had done much to eschew the imperialist past. And in many ways it did. But in others, the imperialist past continued.

Francine Hirsch emphasizes that the new Soviet regime in the 1920s was aware that its nationality policies had the potential to resemble colonization. In fact, Hirsch notes, some within the Party embraced the idea of colonization to an extent. In the debate over how the federal state should be constructed, the premise of Soviet colonization emerged. Narkomnats, relying on data being collected by ethnographers, argued in favor of national-territorial units, while Gosplan advocated for more economically based units. In pursuit of its plan, Gosplan asked Goskolinit the State Colonization Research Institute - to "formulate a philosophical framework for 'Soviet colonization' [kolonizatsiia]." Through analysis of European and American colonization efforts worldwide, Goskolonit sought ways to "explain how in a Soviet socialist context (without an exploiter capitalist class), Soviet colonization policies would enable indigenous peoples...to 
'attain a higher level of material and spiritual culture."' Concerned with how the peoples themselves would perceive such "colonialist" policies, Goskolonit differentiated between kolonizatsiia - agricultural and industrial development - and pereselenie - the "agricultural settlement of uninhabited territories." Kolonizatsiia, Goskolonit reasoned, had an enlightened purpose as it strove for the cultural and economic betterment of the peoples involved. But because many of the non-Russian peoples used the two terms interchangeably, and perceived both to be Russian imperialism, Goskolonit sought to paint tsarist policies as purely pereselenie. In the end, a compromise was reached. Under Stalin's influence, “an approach to the former Russian Empire that combined the Goskolonit vision of Soviet colonization with the Narkomnats vision of state-sponsored evolutionism: a program of intensive economic development coupled with a program of promoting nationhood among the Soviet Union's 'feudal-era' and 'former colonial' peoples" became the basis of Soviet nationality policy. ${ }^{72}$

Through the 1920s, then, the Soviet Union embarked on building a new kind of empire. It was imperialist in that the Bolsheviks extended territorial control over the re-conquered regions of the former Russian Empire. The new regime also intervened in the development of the non-Russian peoples to ensure that they progressed in a decidedly socialist context. Yet it was anti-imperialist in that the new regime's stated purpose was to eradicate nationalist chauvinism and much rhetoric and propaganda was used to persuade the peoples of the Soviet Union of their intentions and to reconcile them.

\section{Consolidating the New Soviet Empire}

By the late 1920s, the Soviet Union had largely re-created the old tsarist empire albeit in a novel way. As we have seen, revolutionary zeal and the desire to overcome previous 
nationalistic chauvinism propelled the Bolsheviks to impose their economic and political systems on the myriad of peoples in the Soviet Union. Simultaneously, korenizatsiia efforts encouraged the development and flowering of non-Russian national identities so long as they did so in a socialist context. The Communist Party's political monopoly centralized power in Moscow, but internal debate was still possible and important policy inputs still came from some non-Russian Party officials. Under Stalin, however, Soviet empire building reached its conclusion. Stalin's continued centralization of power combined with his assault on the non-Russian nationalities effectively consolidated the imperial nature of the Soviet Union thereby allowing the Soviet Union to cross the Augustan Threshold.

The Augustan Threshold, as described by Doyle, is that point at which an empire coalesces into a single entity with a centralized power structure. Center and periphery still exist, of course, but after crossing the threshold, the periphery is integrated with and subordinated to the metropole economically, culturally, and politically. Roman Emperor Augustus deliberately set Rome on this course to eliminate the destabilizing effects of petty Roman political bickering that had frequently resulted in civil wars. It is not clear, however, if Stalin deliberately crossed the threshold. It is most likely that the Soviet Union crossed the Augustan Threshold as an unintended consequence of Stalinist policies. As one of Stalin's many biographers has noted, "For Stalin the supreme criterion of political judgment was the need to protect and enhance his personal power."73 This statement goes far to describe the motivation behind many of Stalin's actions. A supremely paranoid man, Stalin suffered from an inferiority complex that convinced him that others were out to destroy him. As a result, he removed enemies and perceived enemies before they could get to him first. 
Yet, it is too easy to dismiss Stalin's actions - especially the changes he implemented in nationality policy - as simply the product of a power-hungry tyrant. Instead, pragmatism and the drive to modernize the Soviet Union's economy motivated many of Stalin's policies, in particular collectivization and his industrialization drive. According to Mark Tauger, Stalin saw industry and agriculture as "linked" and "mutually dependent" on one another. Therefore, to avoid future famines, Stalin collectivized Soviet agriculture with an eye toward modernizing this vital sector of the Soviet economy so that the country could feed itself and in order to provide the basis for further industrialization. Thus pragmatism and the drive to modernize the Soviet Union motivated Stalin's economic policies. ${ }^{74}$ Stalin's change of course in regard to nationality affairs was also guided by pragmatism, but also by ideology as well.

Again, Terry Martin provides the best explanation as to why Stalin abandoned the pure internationalist rhetoric of the 1920s with an overt support of Russian nationalism. Stalin's change of course took place at the same time that his socialist offensive and cultural revolution was being initiated. Martin explains that this period involved "rapid industrialization, the abolition of private trade, the collectivization of agriculture, dekulakization, and greatly intensified and centralized dictatorship." Moreover, the changing of course in nationality affairs occurred within the framework of the ongoing internal Party conflict between the Left and the Right. Martin explains that in 1928, "The following interpretation of the socialist offensive quickly took shape, particularly in Ukraine: under NEP, the left deviation had been the greatest danger and manifested itself in the great-power chauvinism of Piatakov, Zinoviev, and Vaganian; under the socialist offensive, the right deviation was now the greatest danger; therefore, local nationalism, which was the manifestation of the right deviation in the national republics, had likewise become a greater danger than great-power chauvinism, which was now identified as a 
left deviation."75 In other words, then, what happened in the early Stalin years is that the Party's rhetoric and outlook changed: local manifestations of nationalism were now seen as the greater danger than great-power chauvinism which had been identified by Lenin as the greatest danger to proletarian internationalism. This also means that in Stalin's view, the decolonization process begun by korenizatsiia had gone too far; it was threatening the unity of the Soviet empire.

Because of occurrences in Ukraine, Byelorussia, and other parts of the Soviet Union, it appeared to Stalin that korenizatsiia threatened to disrupt or worse, destroy, the unity of both the Party and the Soviet Union itself. Thus, Stalin worked to reign in the perceived excesses of korenizatsiia. Martin explains that "In order to address this perceived lack of unity, between 1929 and 1931 the Soviet leadership initiated a new campaign designed to foster 'the brotherhood of the peoples." A key feature of this new "brotherhood of peoples" involved the "rehabilitation of traditional Russian culture and Russian nationalism as a force for Soviet unity." Martin adds that "the extreme centralization and statism of the revolution from above pushed the Bolsheviks toward a greater reliance on the one nationality most closely identified with the Soviet state: the Russians." ${ }^{, 76}$ This is the key turning point in Soviet nationality policy that left a permanent imprint on future nationality policies. From this point on, official Soviet rhetoric promoted the friendship and brotherhood of peoples within the Soviet Union while simultaneously heralding the achievements of the Great Russian elder brother. It is also at this point that the Soviet Union crossed the Augustan Threshold - Stalin's socialist offensive, as Martin explains, created an even more centralized state, with nationalities policy seeking to reinforce this centralization - as well as the unity of the country as a whole - all the while couching the argument in terms of "proletarian internationalism" and "the brotherhood and 
friendship of peoples." This will remain the cornerstone of Soviet nationality policy for the remainder of the country's existence.

A perceived lack of unity and its associated danger of permanently dividing the Party is not the only reason why Stalin chose to turn to promoting Russian nationalism as the new form of internationalism. Martin outlines four basic reasons for Stalin's strategy: first, "the centralization and statism of the socialist offensive led to a growing reliance on and trust of the Russians as the nationality most identified with the central state"; second, "As the Soviet Union increasingly abandoned the Piedmont Principle and adopted a defensive foreign policy stance, the cross-border ethnic ties of the non-Russians became increasingly suspect"; third, “collectivization was resisted more fiercely and more violently in the Soviet Union's nonRussian regions" which again seemed to make the Russians the most reliable nationality; and fourth, "Stalin was increasingly concerned about Russian resentment of the Affirmative Action Empire.,"77 Therefore, Martin argues, ideological and pragmatic concerns led Stalin to alter the pure internationalist stance of the 1920 s to a revised position that presented Russian nationalism as the new form of internationalism. It should be stressed, however, that such a change of tact did not mean the complete abandonment of korenizatsiia. While Stalin did implement policies to change local alphabets to Cyrillic to bring them closer to the Russian language as well as to promote the study of the Russian language in the non-Russian regions, he did not give up on what Martin calls the Affirmative Action aspect of korenizatsiia, that is, Stalin continued to favor placing indigenous elites in positions of local leadership though often with a Russian or another Slav as the second in command.

After 1938, Stalin had even abandoned some of the core principles of Soviet nationality policy as "nationality policy virtually disappeared from the annals of Bolshevik history, the 
party's theoretical journals, and its political education system."78 In 1937, Stalin proposed improvements in the Party education system including the production of new textbooks for the training of new Party cadres as well as for educating the general population, especially in the field of history. One product of this reform was the Short Course on the History of the All-Union Communist Party (Bolsheviks).

The original manuscript of the Short Course highlighted the tsarist oppression of nonRussian peoples and it emphasized the role the non-Russian peoples played in the 1905 Revolution and the rising nationalist discontent in the Russian empire between 1905 and 1917. Later chapters of the manuscript pinpointed the danger posed by bourgeois nationalism among the non-Russian peoples of the Soviet Union and heralded the great achievements of Soviet nationality policy.

But Stalin was dissatisfied with the original manuscript, complaining that "no collective farm will ever be able to get this right." Concerned in part that the Short Course was too long and thus inaccessible to the Soviet public, Stalin edited the manuscript himself. His editing of the Short Course removed nationality policy from being a major component of Communist Party policy. He greatly toned down the original manuscript's discussion of tsarist oppression of the non-Russian peoples and he reframed "the prerevolutionary period, from one characterized by both ethnic and class tensions into one in which only class would set the stage for the February 1917 revolution." Lastly, Stalin's editing of the Short Course declared that "the newly formed USSR was 'a single union of Soviet states' - an interpolation that clearly stressed centralization over federalism." Ultimately, "Stalin's decision to displace the [national] issue from the center of the party canon permanently downgraded the multiethnic nature of the USSR's usable past." 
Stalin's editing of the Short Course effectively eliminated further discussion of Soviet nationality policy and removed nationality policy from being a primary focus of overall Party policy. His editing of the Short Course also signaled the further consolidation of power in Moscow at the expense of the Union Republics, a process that will continue through the Brezhnev period. It also meant that nationality policy after 1938 would focus on promoting Russification (in the name of proletarian internationalism) and that the unity and friendship of peoples would be a central theme.

The experience of Soviet Tajikistan ${ }^{79}$ during the Stalin era provides an excellent example of the crossing of the Augustan Threshold under Stalin and the replacement of purely internationalist rhetoric with one of a more Russian nationalist nature. After defeating the Basmachi rebellion in the 1920s, the Bolsheviks immediately set about implementing korenizatsiia policies in what was then the Tajik ASSR. Tajik newspapers were established in Dushanbe and elsewhere along with local schools taught in the Tajik language. Ethnic Russians poured into the Tajik ASSR to train local cadres for Party and governmental work. Land formerly belonging to mosques or to emirs was redistributed to Tajik peasants while Russian Party cadres began laying the foundations for what would, under Stalin, become a cotton monoculture. Overall, Tajikistan in the 1920s resembled many other non-Russian areas of the Soviet Union: Russian Bolshevik immigrants rushed in to teach the ways of Marxism-Leninism, the local language and culture was promoted albeit in the appropriate socialist context, and economic modernization programs were begun.

Stalin began the wholesale collectivization of Tajik agriculture in 1929. As happened elsewhere in the Soviet Union, collectivization triggered resistance both among Tajik peasants as well as among Tajik Party officials. Theresa Rakowska-Harmstone notes that many Tajik Party 
members "were opposed to collectivization and tried to slow it down and to lessen its impact on the people." ${ }^{80}$ Resistance brought about a purge in the Tajik Party apparatus in 1929-1930. Alleged "bourgeois nationalists" were rooted out of the Tajik Party and replaced mostly by Russians. By 1935, membership in the Tajik Comunist Party had fallen by 10,000 members. Thereafter, "the republic was in effect placed under direct Russian tutelage." 81

After collectivization and its related purges, Tajikistan witnessed the complete Stalinization of its affairs. The old intelligentsia - deemed too nationalist by Moscow's standards - was replaced by a new intelligentsia composed of loyal Russians and trustworthy Tajiks. Cyrillic replaced the previous Latin script which had been implemented only in 1929 when Latin replaced the centuries-old Arabic script. By the late 1940s, the Stalinization of Tajik culture had been completed. Mirzo Tursun-Zade, the premier Tajik literary figure of this period who won the Stalin prize for literature, composed in 1948 a book-length poem entitled The Indian Ballad that contrasted the poor conditions of British India with the greatness of Soviet Tajikistan. In this poem, Tursun-Zade credits the Russians for Tadzhikistan's escape from oppression and backwardness: "Glory to our fathers in the reaches of the earth/For many years they fought with the enemy. The Russian brother - he is our chief - In the war years he helped/all the peoples of the country." ${ }^{, 2}$ This, then, is the culmination of Stalinist nationality policy in Tajikistan, a process that was replicated in all parts of the Soviet Union.

Tajikistan's experience is also evidence that Stalin's Soviet Union crossed the Augustan Threshold. Whereas before Stalin, korenizatsiia policies had both imperialistic and nonimperialistic aspects, Stalin's practices were all but imperialistic. Collectivization, the Purges, changes to education policies, and the overall propaganda effort that gave the Russians a privileged place among the Soviet peoples ensured that the center remained inextricably tied to 
the periphery. By the 1940s, Stalin had installed reliable cadres - both Russian and non-Russian - into the leadership positions of the non-Russian union republics and ASSRs. It was made very clear that nationalist deviations on the part of non-Russians would not be tolerated. Non-Russian cultural and artistic elements served to hail the elder Russian brother. Economically, regions of the Soviet Union were controlled by Moscow and each region increasingly came to specialize in certain economic activities. Central Asia, for example, became a cotton monoculture, supplying virtually all of the cotton for the Soviet textile industry. Stalin thus tied the empire together. In the words of Tursun-Zade, "Like spreading rays Moscow sends the warmth of the new life into each town and village." 83 Substitute the "spreading rays" with political and economic control and we are left with a coherent Soviet empire as constructed by Stalin.

\section{World War II and Soviet Imperialism}

World War II presented the Soviet Union with a tremendous challenge as the German invasion and occupation threatened to destroy the country. In some respects, World War II was the Soviet Union's finest hour as Stalin successfully rallied the Soviet peoples to defeat the German occupier. But World War II also was the point at which Soviet imperialism reached its apex. Even before the German invasion, the Soviet Union annexed Estonia, Latvia and Lithuania along with a large section of eastern Poland and it stripped Bessarabia (Moldavia)

from neighboring Romania. ${ }^{84}$ Moreover, in the late stages of the war, Stalin ordered the deportations of numerous peoples from their homelands such as the Chechens, Ingush, the Crimean Tatars, and the Volga Germans for their alleged collaboration with the German occupiers. Stalin's consolidation of the Soviet Empire in the 1930s, his enlargement of the empire in 1940, and his earlier policies of collectivization and the Terror combined to encourage 
many peoples in the USSR's western regions to collaborate with the Germans or to seek independence. Thus, while World War II was the point at which the Soviet Union was most imperialistic, it also sparked a decolonization process that ended with Stalin's death in 1953 but re-emerged in the 1960s.

During the war, up to one million Soviet citizens fought alongside the Germans, though most of these did so to avoid detention in German camps or being sent to Germany as forced labor. ${ }^{85}$ As German troops arrived in 1941, peoples in the Baltic, Byelorussia and Ukraine greeted the Germans as liberators and, in the case of Lithuania, the German invasion rekindled hopes for restored independence. Guerilla movements developed such as the Forest Brethren in the Baltic states and the Ukrainian Insurgent Army, the armed wing of the Organization of Ukrainian Nationalists (OUN). These guerilla movements fought against both the Germans and the Soviets and they continued fighting the return of Soviet rule into the 1950s.

Of these nationalist movements during the war, the most complicated case was that of the Ukrainians. This is because before the war, the Ukrainians were divided among several states: the Soviet Union, Poland, Czechoslovakia, and Romania. As a result, a Ukrainian integral nationalism developed in the 1920s in response to Ukraine's failed bid for independence in 19171920. Integral nationalism "called for the creation of a new type of Ukrainian, one who was unconditionally committed to the nation as a whole and to independent statehood." ${ }^{\prime 86}$ During the interwar period, this form of Ukrainian nationalism was centered in western Ukraine, which at the time formed part of Poland with a smaller section belonging to Czechoslovakia. Ukrainian integral nationalism in the 1920s and 1930s was primarily targeted against Polish rule.

In 1920, a small group of Ukrainians meeting in Prague formed the Ukrainian Military Organization (UVO), "an underground organization that sought to continue the armed struggle 
against Polish occupation.” In 1929, members of the UVO and several Ukrainian student groups formed the OUN at a meeting in Vienna. ${ }^{87}$ By 1941, the OUN was centered in western Ukraine and had up to 20,000 members.

The Soviet annexation of western Ukraine in 1940 aroused the OUN's enmity against the Soviet Union in addition to its ongoing opposition to the Poles. Above all, the members of the OUN wanted Ukrainian independence. Thus, in the immediate aftermath of the German invasion, the OUN initially collaborated with the German occupiers. Collaboration was based on two factors: first, OUN members believed that the Germans would accept an independent Ukraine; second, the integral nationalism of the OUN had certain similarities with the integral German nationalism espoused by the Nazis. ${ }^{88}$

Collaboration with the Germans ended when the Germans denied the OUN's declaration of Ukrainian independence and Stepan Bandera, the leader of the OUN Bandera faction, was placed under house arrest in Berlin. Meanwhile, the Ukrainian Insurgent Army (UPA) formed, initially independent of the OUN, in western Ukraine with the intention of clearing the region of remnants of the Red Army. In late 1941, when the Germans attempted to disband it, the UPA turned into an underground insurgent army fighting against both the Germans and the Soviets. The UPA enjoyed wide support among the western Ukrainian population as its numbers swelled to at least 30,000 fighters by 1943 . By 1944, the UPA began cooperating with the OUN Bandera faction and in July 1944, at the behest of the OUN-B, delegates from western and eastern Ukraine joined to form the Ukrainian Supreme Liberation Council (UHVR). The UHVR sought to unite all Ukrainian nationalists - integral and non-integral nationalists alike - and it "urged the non-Russian nationalities of the USSR to unite against Moscow." Moreover, the OUN-B 
declared, "The OUN is fighting against imperialism and against empires ... for this reason, the OUN is fighting against the USSR and against Germany's 'New Europe'.”89

The OUN and the UPA continued their activities after the return of Soviet power to western Ukraine in 1944. At this time, Nikita Khrushchev was Party First Secretary in Ukraine and he was in charge of the Sovietization of western Ukraine (the collectivization of agriculture, the re-establishment of Party organs in western Ukraine, etc.). He also oversaw the battle against the OUN and the UPA. This turned into a savage civil war in western Ukraine that lasted into the early 1950s and involved atrocities committed by both sides. At first, Khrushchev downplayed the strength of nationalist forces in western Ukraine, he reported to Stalin in 1944 that the mood in western Ukraine was "very good and Soviet ... [there is] no sign of [nationalist] formations." His assessment was far from the truth. When Soviet troops returned, "nearly every western Ukrainian peasant household had dug shelters concealing weapons, ammunition, food, and clothing." Between February 1944 and May 1946, 110,825 "bandits" were killed by Soviet forces with 250,676 more having been arrested. By 1952, some 600,000 had been arrested in western Ukraine, a third of them were executed. Moreover, Moscow "imported easterners to man western party and police agencies." Khrushchev was intimately involved in these efforts to eradicate nationalist guerilla fighters in western Ukraine, though he appeared to have no guilt about his involvement in the violent measures used in western Ukraine. ${ }^{90}$ Similar violence occurred in the Baltic republics after the war as Soviet forces sought to eradicate the Forest Brethren. $^{91}$

The Soviet annexation of western Ukraine, the Baltic states, and those parts of eastern Poland that were attached to Byelorussia as well as the subsequent German invasion in 1941 touched off mass nationalist uprisings, particularly in the Baltic states and in western Ukraine. 
Although armed uprisings against Soviet rule in these areas ended in the early 1950s, they still served as a rallying point for local nationalism. After a brief lull in the 1950s, nationalist dissent in these areas re-emerged in the 1960s in part as a legacy of Khrushchev's Thaw. Soviet imperialism under Stalin, then, led to the formation of independence movements in the western Soviet Union, which contributed to the development of a decolonization process in the Soviet Union after Stalin's death.

\section{Eastern Europe - the Soviet Union's Princely States}

At the end of World War II, the Soviet Union sponsored the formation of communist regimes in Poland, Czechoslovakia, Hungary, Romania, and East Germany. During the Cold War, these states were referred to in the West as the Soviet Bloc as Eastern Europe (with the exception of Yugoslavia and later Albania) was considered to be in the Soviet sphere of influence. Although an in-depth examination of Soviet policies in Eastern Europe is beyond the scope of this study, some observations can be made regarding Moscow's relations with the states of Eastern Europe. The fundamental question here is did Eastern Europe belong to the Soviet Empire proper, or were these states part of a Soviet informal empire or did they simply belong to the Soviet sphere of influence?

Edy Kaufman described Eastern Europe as the Soviet Union's sphere of influence along lines similar to the United States' sphere of influence in Latin America. He argues that in the interwar period, Moscow grew increasingly fearful of the growing threat of hostile powers along its periphery such as Nazi Germany and Japan. Moreover, the alliances formed among the countries of Eastern Europe such as the Little Entente and the Baltic Entente, "were considered as threats by Moscow, and the Soviet Union continually accused the French 'imperialists' of 
trying to erect a cordon sanitaire around it." As a result, according to Kaufman, Moscow sought "the consolidation of a buffer zone which distanced the threats of European powers." This desire for a buffer zone was enhanced by the German invasion of the Soviet Union in 1941, which "strongly influenced the Kremlin in maintaining full military control over the Eastern European states." 92 Moscow then established communist regimes in the countries of Eastern Europe to establish this buffer zone to enhance Soviet security.

Zbigniew Brzezinski, on the other hand, places more emphasis than Kaufman on the level of control Moscow had over Eastern Europe. Though he does not specifically refer to Eastern Europe as belonging to a Soviet empire, he does outline five primary Soviet objectives in Eastern Europe after the war that appear to be imperialistic: 1. Deny Eastern Europe to Germany to enhance Soviet security; 2. To ensure that the states of Eastern Europe would not be controlled by domestic forces that, while hostile to Germany, may also be hostile to the Soviet Union; 3 . To use the states of Eastern Europe for the Soviet Union's postwar economic recovery; 4. To deny Eastern Europe to the capitalist world; and 5. To gain new territory for socialism. ${ }^{93}$ Soviet objectives in Eastern Europe, then, combined pragmatic defense considerations with imperialistic economic exploitation and the ideological desire to spread socialism.

Brzezinski also refers to the levers of control Moscow used on the communist states of Eastern Europe. Moscow frequently intervened in the internal affairs of the communist parties of Eastern Europe especially in the selection of party leaders. Whereas in the immediate postwar years, the communist parties of Eastern Europe avoided reference to the Soviet experience due to anti-Russian or anti-Soviet sentiment in those countries, after 1948 this policy changed as they "gave way more and more to an insistence on the leadership of the Soviet Union." ${ }^{94}$ Moreover, "Two of the constitutions, those of Hungary and Poland, both products of a more ripened 
Stalinism ... actually praised the USSR in their texts - not a frequent procedure among sovereign states." Brzezinski also notes that that the states of Eastern Europe always had closer diplomatic ties with Moscow than they had with one another. Societies for promoting friendship with the Soviet Union were established in each Eastern European country which "sponsored Soviet exhibits, featured Soviet movies ... and organized Russian language classes for adults (compulsory for schoolchildren)." The teaching of Russian, according to Brzezinski, was "used as a medium for instilling devotion to the USSR and to Stalin." "95 The teaching of Russian in Eastern Europe is very similar to the language policies pursued inside the Soviet Union, and thus, reinforces the imperial nature of Moscow's relationship with the states of Eastern Europe.

Like Brzezinski, John Lewis Gaddis also highlights the Soviet Union’s security concerns in Eastern Europe and he argues that this was the primary reason Moscow sponsored the formation of communist regimes in those countries. However, Gaddis argues that Eastern Europe constituted an informal Soviet empire, just as he insists that the United States established an informal empire in other parts of the globe during the Cold War. ${ }^{96}$

As occurred in the Soviet Union, the situation in Eastern Europe changed after the death of Stalin. Khrushchev's de-Stalinization in the USSR endangered the Stalinist leaders in the Eastern European states. It was at this stage that more diversity began to appear in the Eastern European countries. Uprisings in Poland in 1953 and again in 1956 and the Hungarian Revolution of 1956 failed to remove the communist regimes in those countries, but they did succeed in beginning the process of de-Stalinization. ${ }^{97}$ As a result, Polish agriculture remained uncollectivized and Hungary was able to experiment with market socialism in the 1960s. East Germany, Bulgaria, Romania, and (until the Prague Spring of 1968) Czechoslovakia remained essentially Stalinist. After 1956, Moscow tolerated a measure of diversity within Eastern 
Europe. It was only when Czechoslovakia threatened to go too far in liberalizing its system in 1968 did the Soviet Union forcibly intervene to prevent "losing" Czechoslovakia. As the Solidarity movement grew in 1980-1981, Moscow threatened to intervene there militarily but did not when martial law was declared and Solidarity was forced underground. Thus, after 1956, Moscow retained a preponderance of power in Eastern Europe, but it did not exercise complete control there as it did in the internal Soviet Empire. Eastern Europe, then, constituted a Soviet informal empire.

The Soviet Union's relationship with the states of Eastern Europe was similar to Britain's relations with the Princely States of India. Whereas “British India was 'formal empire' (colonies under direct imperial rule) ... each headed by a British governor, lieutenant-governor, or chief commissioner”, Princely India “was ‘informal empire’ (protectorates and protected states or territories under indirect imperial rule), comprised of over 600 'native states' and tribal territories, each with its own ruler or chief overseen by a British resident or agent."98 Already in the $18^{\text {th }}$ century, "the East India Company was forging diplomatic ties with Indian kingdoms, and by the second decade of the nineteenth century virtually all the major 'country powers' had been linked to the Company by treaty." During the Great Revolt (Mutiny) in 1857, the "princely states as a body had proved remarkably steadfast during the crisis and ... their support had helped to turn the tide." The princely states, then, proved valuable to the British. ${ }^{99}$ For their part, the rulers of the princely states saw advantages to cooperating with the British as they "sought to achieve dominance in succession disputes, to establish a superior position vis a vis their kinspeople, and to gain needed support in military confrontations with other regional states." 100 
Like the indigenous rulers of the Indian Princely States, the leaders of the communist regimes in Eastern Europe were willing collaborators with the Soviet Union. And just as British agents supervised the indigenous rulers in the Princely States, Soviet ambassadors kept close watch over the functions of the ruling parties in Eastern Europe and they reported their observations to Moscow. ${ }^{101}$ To be sure, the Princely States in India predated the coming of British rule to India whereas the communist leaders of Eastern Europe were brought to power by the Soviets. But the key similarity is that Moscow allowed some freedom of action in Eastern Europe after the crushing of the Hungarian Revolution in 1956. Moreover, the leaders of Eastern Europe benefitted from Soviet informal empire in ways similar to the rulers in the Princely States, primarily in the fact that it gave them power that they did not have before World War II. Moscow did indeed exercise great power over the states of Eastern Europe, but given the diversity that appeared among the Eastern European countries after 1956 and the recalcitrance displayed by Romania’s Nicolae Ceausescu beginning in the mid-1960s, Eastern Europe’s relations with the Soviet Union were more characteristic of informal empire.

\section{Conclusion}

The anti-imperialist Soviet Empire came about due to the tsarist historical legacy and Stalin's policies that ended korenizatsiia in favor of centralizing the Soviet Empire and promoting Russian as the vehicle for internationalization. The Bolsheviks initiated korenizatsiia to promote local national identities and to combat great Russian chauvinism, which, in their view, had been one of the essential flaws in Tsarist policies. Thus, korenizatsiia can be explained as an effort by the Bolsheviks to curry favor with the non-Russian peoples of the former Tsarist empire and thereby prevent the further loss of territory after Poland and the Baltic 
states gained independence. Moreover, korenizatsiia indicates that the Bolsheviks believed nations and national identities were malleable; their formation and development could be controlled to serve the broader purpose of building socialism in the Soviet Union. Through promoting non-Russian national identities, the Bolsheviks believed that the non-Russian peoples would develop their own cultures within a socialist context and eventually they would merge into an all-encompassing Soviet national identity. However, in this respect, korenizatsiia failed and instead promoted the development of a decolonization process which led Stalin to end korenizatsiia policies in favor of consolidating the Soviet Empire. In addition, early Bolshevik policies aimed at engineering the creation of nations and national identities where they either did not exist or were very weak, were not unlike other policies carried out in the British and French empires in the early $20^{\text {th }}$ century. Korenizatsiia set in motion a decolonization process that, despite Stalin's efforts, could not be eradicated. Instead, it boiled beneath the surface and received further encouragement under Khrushchev, as will be discussed in Chapter Two. It was thus up to Brezhnev to keep the lid on this decolonization process. Chapters Two and Three will show that the Brezhnev leadership relied on the tools used by Stalin - minus the terror - to maintain the empire, while also relying on the tenets of Leninist theory to educate its citizens on the merits of proletarian internationalism and the magnanimous qualities of the Russian elder brother. 


\section{CHAPTER TWO}

\section{BREZHNEV'S ANTI-IMPERIALIST EMPIRE}

In Chapter One, I argued that the Soviet Union formed as an anti-imperialist empire due in large part to the Bolsheviks' revolutionary zeal, which prevented them from willingly losing more territory to the enemies of their revolution. The Bolsheviks also inherited the tsarist imperial heritage along with the historical and nationalistic baggage that came along with it. In part to lighten the load of this baggage, Lenin and Stalin created a federal Union of Soviet Socialist Republics and enacted the policies of korenizatsiia in an effort to co-opt the forces of nationalism that threatened to destroy the unity of the new socialist country. As stated in Chapter One, Terry Martin argues that Stalin by 1929 began to fear that korenizatsiia had gone too far in promoting the non-Russian national cultures, thus he rolled back the more ambitious elements of korenizatsiia and turned to promoting the "friendship of peoples" and reliance upon the Russian people as the most reliable in order to reign in the centripetal forces which threatened both the Party and the state. It is important to remember, however, that Stalin never completely abandoned korenizatsiia; he merely sought to keep it under closer control while simultaneously rehabilitating the more nationalistic aspects of Russia's tsarist past. The nadir of korenizatsiia came when Stalin ordered the wholesale deportation of many of the peoples of the North Caucasus as well as the Volga Germans and the Crimean Tatars to Central Asia in 1944. After 1930, Stalin's approach to the nationality question meant a scaling back of korenizatsiia, the rehabilitation of Russian national identity and the tsarist past, the promotion of the "friendship of peoples", and the use of terror and mass violence to deal with those peoples - such as the Chechens, for example - whom Stalin suspected of covert anti-Soviet activity. One of the 
aims of this chapter will be to show that the leaderships of Nikita Khrushchev and Leonid Brezhnev continued some aspects of Stalin's nationality policy, with the primary difference being that never again would the Soviet regime resort to the tactics of mass violence and terror that Stalin used. Korenizatsiia was revived by Khrushchev and continued by Brezhnev through his policies toward state and party officials, though not to the extent to which it had been implemented in the 1920s. Khrushchev's Thaw reignited the decolonization process, which, as will be discussed in this chapter created trouble for the regime. The Thaw initially continued into the early years of the Brezhnev era, but Brezhnev worked to contain the decolonization process that Khrushchev had reignited in places such as Ukraine, yet Brezhnev's policies also contributed to the decolonization process in the Central Asian republics.

This chapter begins with a review of the Khrushchev period to demonstrate that Khrushchev's de-Stalinization policies had the effect of reigniting the decolonization process that korenizatsiia had begun in the 1920s and that Stalinist violence had effectively driven underground by the late 1930s. It must be emphasized here that Stalin was the last Soviet leader who actually devoted considerable time to the nationality question, though even under Stalin, economic questions were always deemed more important. Thus, Khrushchev and Brezhnev inherited the inertia of Soviet nationality policy from Stalin. They tweaked it from time to time, but they never devoted nearly as much attention to it as they did to economic and foreign policy concerns. In many respects, as will be demonstrated in this chapter, Khrushchev's "nationality policy" really was just the byproduct of his overall de-Stalinization program.

After reviewing Khrushchev's impact on Soviet nationality policy, this chapter then turns to the main focus of this study: the Brezhnev era. This section begins with a review of the historiography of the Brezhnev era as it pertains to the nationality question. Above all, the 
historiographical review will show that this is a period that has been overlooked by historians in the last 25 years and that the works that do exist are divided on the issue of Brezhnev-era nationality policy. My work fits into this historiography as it seeks to understand the ideological and pragmatic basis of Brezhnev's policies, it places the Soviet Union into a broader world history context, and it will demonstrate that the Brezhnev leadership had contradictory policies that both sought to consolidate further the Soviet Empire, yet contributed to the decolonization process.

Next, this chapter will discuss the ideological basis of Soviet nationality policy. This will be done for three main reasons: first, this is necessary in order to be able to see the world through the Kremin's eyes. Such a view will enable us to understand why the Soviet leadership pursued policies that to outsiders look decidedly imperialistic, but to the Marxist-Leninist mind it is the height of democracy. Secondly, the ideological discussion will help to illustrate the changing nature of the Brezhnev leadership; we witness a regime that largely continued Khrushchev's more liberal outlook until around 1968, when the Brezhnev leadership grew increasingly conservative and Brezhnev began to formulate his Developed Socialism theory, which in the 1970s forms the basis of Brezhnev's nationality policy. Finally, the ideological aspect of Brezhnev's Developed Socialism theory will culminate in the adoption of the new Soviet Constitution in 1977, which will enshrine into the fundamental laws of the Soviet Union a further consolidation of the Soviet Empire. An analysis of the new USSR Constitution and the new Union Republic constitutions will be provided in Chapter Six. 


\section{Khrushchev's Anti-Imperialist Empire}

Stalin's death in 1953 ushered in great changes in the Soviet Union. Gone were the days of arbitrary state violence and mass purges that characterized the Stalinist Era. Gone too, at least for a short time, was the cult of personality. The Soviet Union would now be led by a collective leadership that would seek legitimacy through continued economic progress and through building socialism, which ultimately (by 1980 Khrushchev had once promised) would propel the Soviet Union into the Communist stage of history. According to Ronald Suny, after Stalin, the "Soviet government would never again turn into an autocracy; it had become a bureaucratic oligarchy." Power, under Khrushchev's leadership, would now be more decentralized "and a wider range of people would be included in politics and administration."

Again, it must be remembered that for Khrushchev and his successors, the nationality issue in the Soviet Union had assumed a secondary importance. The Soviet regime placed higher priority on further economic development - in the 1950s, postwar rebuilding still dominated much of this effort - as well as on competition with the United States in the context of the Cold War. Moreover, Khrushchev thought that the nationality issue had largely been solved. According to Suny, Khrushchev "firmly believed that ultimately the various peoples of the USSR would grow closely together culturally until they blended into a single nation."2 Emphasis now was placed on the coming of the new "Soviet man" - a supranational, a-national citizen who was an amalgamation of all Soviet peoples, but of course spoke Russian and thereby was probably more Russian than anything else. But this Soviet man was the logical product of socialist internationalism, itself the result of a few decades of socialist social engineering. But to Khrushchev, according to Ben Fowkes, the new Soviet people "had a common motherland - the 
USSR - and a common economic base and class structure. The Soviet people, of whatever nationality, had a 'second native tongue' - the Russian language. The rapprochement (sblizhenie) of the Soviet nations, which had previously been seen as taking place after their 'blossoming' (rastsvet), was now to be concurrent with it."' Assimilation, then, was the official watchword, not too unlike French assimilationist efforts in Algeria and in West Africa.

Yet, the nationality issue in the Soviet Union had not been solved. The new Soviet man still existed only in the imaginations of the most ardent supporters of socialist internationalism. In fact, some of Khrushchev's policies contributed to the development of nationalism in the Soviet Union, which naturally worked against the birth of the new Soviet man. Chief among these policies are Khrushchev's attempt to decentralize decision making in the Soviet system and his language policies that continued to favor the Russian language.

Khrushchev's administrative reforms centered on economic change. To boost further economic growth as well as to promote higher levels of Party activism, Khrushchev created regional economic councils known as sovnarkhozy. These councils theoretically would decentralize many aspects of economic decision making thereby bringing "the 'center of gravity' of public administration 'closer to production.' This would make possible the 'tapping of reserves that are latent in the socialist economy." To counteract any "localist tendencies" that such a reform would likely bring, Khrushchev argued that greater Party activism at both the central and local levels would root out such deviant behavior. ${ }^{4}$ Thus, the sovnarkhozy would solve two problems at once: it would foster greater economic and political participation at the local and regional levels while simultaneously reinvigorating Party activism, which could further consolidate the building of socialism and ultimately hasten the coming of communism. This reform would also be accompanied by greater emphasis on the Soviet Union's persistent 
agricultural problems - an area of expertise for Khrushchev. His most famous scheme for increasing agricultural output was his Virgin Lands program, which encouraged thousands of young Party activists to plow up the grasslands of Kazakhstan and establish permanent agriculture. Despite initial success in the first years of the Virgin Lands Campaign, native Kazakhs resented the influx of thousands of new Russians onto their native territory, which helped to foster a growing anti-colonial sentiment among many Kazakhs. On the surface, the influx of Russian and other Slavic workers into the virgin lands of northern Kazakhstan appears imperialistic - foreigners were colonizing the ancient grasslands of native Kazakh nomads. Yet, this was not Khrushchev's intent. His zeal for fixing the Soviet Union's persistent agricultural problems blinded him to the effects this policy would have on inter-national relations in the Soviet Union. Indeed, this episode is perhaps the best example of Khrushchev's policy making nationality policy took a back seat to Khrushchev's primary goals of de-Stalinization and economic reform. But the byproducts of these policies served to reignite the decolonization process.

Khrushchev's decentralization plans came largely as a result of the power struggle between himself and Malenkov, Molotov, and Beria from 1953 to 1956. Martin McCauley suggests that Khrushchev's decentralizing tendencies grew out of his need to secure a base of political support against his rivals. Khrushchev needed a patronage network and that his "orbit of patronage embraced republic, oblast, and krai government leaders" among others. Because his opponents derived their support from within the central government structures in Moscow, Khrushchev realized that decentralization of the economic decision making process could help him in two important ways: it "would undermine the political bases of his challengers, and, because there was no intention to move to a market economy, an organization would be needed 
to allocate resources and control, coordinate and resolve the conflicts which would inevitably rise." This organization would be the Communist Party. While his opponents would use the government apparatus to base their support, Khrushchev would turn to the Party and its nomenklatura system to "facilitate the placing of the right people in government and local authority or soviet jobs."5 This emphasis on decentralization would serve to reignite the decolonization process in the Soviet Union as will be explained below.

As stated above, Khrushchev believed that the nationality issue had largely been solved. Therefore, nationality policies took a back seat to his economic policies. When he did mention nationality affairs, he focused on the new Soviet man, internationalism, and on linguistic policies. Helene Carrerre d'Encausse suggests that Khrushchev in some ways reinvigorated the korenizatsiia policies of the 1920s. On May 30, 1956, the CPSU Central Committee and the Council of Ministers issued a joint decision that transferred a number of federal enterprises to the various Union Republics. In 1957, decisions were taken that enhanced the judicial and legislative powers of the republics while also giving more power to the councils of ministers in the republics. Encausse argues that for Khrushchev's reforms to have real meaning, "a real place had to be given to the national cadres - hence a return to the "indigenization" practiced in the 1920s. At every level, in every sphere, the late 1950s were marked by an increased number of indigenous cadres and by a decline in the representatives of the central government."6 Perhaps not unexpectedly, these reforms prompted displays of nationalism throughout the Soviet Union. In August 1956, the Supreme Soviet in Azerbaijan declared Azeri to be the only official language in the republic - a slap in the face to Khrushchev's pro-Russian language pronouncements. This is also surprising as it reveals that nationalist sentiments survived the years of Stalinist repression. Other instances of "local chauvinism" appeared as well. Such 
displays of nationalism, Encausse suggests, were "encouraged by Soviet concessions and a foreign policy that supported nationalist movements." Khrushchev attempted to counter these developments with a renewed official insistence on internationalism. Khrushchev claimed that Soviet achievements in cultural and economic progress since the 1920s had completely changed the multinational character of the country. Therefore, Khrushchev summed up the history of Soviet nationality development in three points: “(1) The egalitarian course charted by Lenin had led to the 'flowering' of national consciousness and national cultures; (2) economic and cultural progress, as well as the trust generated by Lenin's policy, had produced the 'rapprochement' of the nations; and (3) this stage of the march toward Communism would also lead toward the 'fusion' of those nations, creating a new type of community in which the memories of past inequality or injustice would disappear."7 Thus it would appear that Khrushchev’s hopes called for assimilation of the Soviet peoples similar to Laurentie's plan at Brazzaville to restructure the French Empire. Only Khrushchev hoped to take the project further in his country by completely eradicating all national differences while maintaining the integrity of the Soviet Union. However, his policies ultimately had more of a centrifugal effect rather than consolidation.

As Khrushchev predicted the end of national differences in the Soviet Union, he also enacted or supported policies that favored the Russian language over the non-Russian languages. Suny makes the contradiction clear when he states that "Khrushchev increased emphasis on Russian-language teaching and allowed those living in non-Russian republics who did not wish to study the local language to choose not to. Thus, a double standard for language learning was enforced: everyone had to learn some Russian but Russian-speakers did not have to learn another Soviet language, even if they lived in a non-Russian republic." ${ }^{\circ}$ But in promoting the Russian language, Khrushchev was not necessarily promoting Russian nationalism. Judging from 
Khrushchev's actions and pronouncements during his time in power, he was devoted to internationalism and the idea of the fusing of nationalities into an overarching Soviet national identity. But he did believe that the language of the Soviet nationality would be Russian - it was the language of Lenin and the early Bolsheviks and therefore it was the language of progress and the carrier of advanced culture and knowledge. But above all, Russian was the language of convenience. It had served as the lingua franca of the former Russian Empire, it was spoken by the majority of the Soviet population. To select arbitrarily a new common Soviet language or to enact measures to require all business to be conducted in over 100 different languages simultaneously would have been enormously difficult and woefully inefficient, if not downright impossible.

Khrushchev's policies raise a vital question: were they imperialist in nature or did they promote decolonization? Before answering this question, it is important to remember that because the Soviet Union was an anti-imperialist empire, the leaders themselves did not consciously promote imperialist or non-imperialist policies. But the effects of such policies can still be analyzed for their imperialist or non-imperialist qualities. The historiography that addresses this question is divided. John Keep suggests that these policies were more imperialistic in their effects. When discussing accusations that Khrushchev pursued harsh Russification measures in the Soviet Union, particularly in the western borderlands, Keep reminds us that "one has to distinguish between russification and sovietization. Russians, too, were victimized by the regime's repressive policies." If the Soviet Union constituted an empire and its leaders were decidedly imperialistic, then “theirs was a 'neo-imperialism' of an unconventional type. It was designed to bring about a utopian supranational order based on Marxist-Leninist ideology, not just to ensure Russian hegemony over 'lesser breeds." "9 Keep 
argues further that Khrushchev's decentralizing policies allowed for the creation of a new indigenous elite in the non-Russian republics. Because this new republic elite had a vested interest in maintaining the system (and thus the empire), then "a growing proportion of the native elite was being co-opted into the ruling Party. This can be taken to indicate a greater measure of support for its policies, although of course careerist motives were also present." ${ }^{10}$ Moreover, Keep notes that 'Khrushchev stood for the principle of 'internationalization of cadres', which in practice meant that outside the RSFSR the second Party secretary was usually a Russian with more power than his nominal superior, a native." 11 This, then, was a Soviet imperialism, not necessarily a Russian imperialism.

Ben Fowkes has a somewhat different interpretation. He points out that in Uzbekistan, "The life of the local community... was regulated by a Council of Elders rather than by the local soviet; but no clash between the two authorities, traditional and modern, took place because the Senior Elder was none other than the chairman of the soviet." This fact, along with Khrushchev's internationalization of cadres policies, meant that “Quietly, by imperceptible stages, a non-Russian elite came to the top in the union republics, thus introducing an irreversible process of decolonization within the Soviet Union...The maintenance of the multinational Soviet empire came to depend on the loyalty of these elites." ${ }^{12}$ Add to this situation the national dissident movements of the 1960s and 1970s and decolonization seems to be firmly in place by the Brezhnev period.

Finally, Suny is somewhere in the middle of these two interpretations. He points out that Khrushchev promoted and encouraged the Russian language and culture in the western borderlands, the Baltic Republics and Ukraine in particular, but "in the south the major nationalities in the Central Asian and Transcaucasian republics increasingly became dominant in 
their home republics." ${ }^{\prime 13}$ Suny highlights an important distinction that appeared during the Khrushchev period and one that would extend and intensify under Brezhnev - Moscow’s approach differed between the western borderlands and the Central Asian and Transcaucasian republics. Russification and Soviet "neo-imperialism" appear to have been pursued with more rigor in the western borderlands.

It is at this point that we can see the continuation of the regional variation in terms of nationality policy that, as indicated in Chapter One, has deep roots in the tsarist legacy of the Soviet Union. Recall that in the late tsarist period, nationality policies varied depending on location within the empire and which people were being dealt with. Since the $19^{\text {th }}$ century, the western peoples of the Russian Empire - the Slavs in particular such as the Ukrainians, Belorussians and Poles - received "harsher" treatment from St. Petersburg, whereas Russian policy tread a bit more lightly in Transcaucasia and lighter still among the Muslim peoples of Central Asia. The Bolsheviks inherited this legacy. As explained in Chapter One, early Bolshevik rhetoric was couched in terms of perceived levels of development, which, as Martin argues, led to a dichotomy of peoples: those deemed more "advanced" were considered Western, while the more "backward" peoples were considered Eastern. And, according to Martin's Piedmont Principle, foreign policy concerns influenced early korenizatsiia policies; the Bolsheviks promoted Ukrainian and Belorussian culture in an attempt to lure those Ukrainians and Belorussians living in the new Polish state, Moldavians received their own ASSR to attract those Moldavians living in Bessarabia, a region that Romania seized from Russia in the tumultuous aftermath of World War I.

These elements continued into the Khrushchev period albeit in a different form and for slightly different reasons. If in the 1920s, we can speak of two broad Soviet Unions (East and 
West) with smaller subsets within each, by the 1950s we can see the emergence of four Soviet Unions: the Western USSR (the Baltic States, Belorussia, Ukraine, and Moldavia), the Transcaucasus (Georgia, Armenia, and Azerbaijan), Central Asia (Uzbekistan, Turkmenistan, Tajikistan, and Kyrghizstan) and finally the RSFSR and its multitude of autonomous republics, oblasts and regions. These four Soviet Unions emerged during the late Stalinist period as World War II and the onset of the Cold War contributed to their formation, particularly in regard to the Western Soviet Union. It was here that Stalin had added to the Soviet patrimony by annexing the Baltic States, parts of Eastern Poland, Western Ukraine, and Moldavia. Because of the manner in which these territories were added (especially the three Baltic republics) and because of the recent history of these regions, nationalism was an ongoing threat in the Western Soviet Union. Indeed, Stalin assigned Khrushchev the task of incorporating the Western Ukraine into the Soviet Union and nationalist bands continued to clash with the Red Army here into the early 1950s. These events combined with the onset of the Cold War, which made the Western Soviet Union the front line against possible "imperialist invasion" led to Moscow's heightened sensitivity to manifestations of nationalism in the Western Soviet Union, whereas such manifestations were more tolerated in the other Soviet Unions.

Overall, Khrushchev's policies were generally imperialist, though not to the degree of Stalin and not as imperialist as Brezhnev's policies would be during his tenure. Khrushchev promoted the Russian language at the expense of non-Russian languages. But his decentralizing policies did promote the coming to power of local indigenous elites, especially in the Central Asian republics. Moreover, Khrushchev's policies differed based on which region of the Soviet Union is in question. Thus, Khrushchev had imperialist tendencies, but he was not the imperialist that Stalin was nor was he as imperialist as his successor. 


\section{Leonid Brezhnev's Anti-Imperialist Empire}

Leonid Il'ich Brezhnev assumed the position of First Secretary of the Communist Party of the Soviet Union in October 1964 as the result of a coup that ousted Nikita Khrushchev. Accusing Khrushchev of hatching "hare-brained" schemes and increasingly wary of his cavalier approach to foreign policy, the Party replaced the often erratic Khrushchev with the more conservative Brezhnev. It is at this point, in the fall of 1964, that the Soviet Union enters the Brezhnev era - the period of peace and stability and the time at which the Soviet Union reached its height and its maturity. For the first time in Soviet history, the next 18 years would not be marked by devastating wars or revolutions from above. It is for this reason that the Brezhnev era should be studied - it is the only time that we can observe the Soviet Union as a mature socialist state that is not fighting a major war or undergoing radical reforms. Yet, recent literature on this crucial period is relatively sparse when compared to the vast, wide-ranging historiography of the previous periods of Soviet history.

Since 1970, much has been written about the nationality question during the Brezhnev years, although virtually none of these works focus exclusively on the Brezhnev era in particular. The books written since 1970 most often treat the Brezhnev years as just one period in the overall Soviet experience. Many journal articles exist that examine the Brezhnev era, but these typically only delve into a particular aspect of the nationality question during this period. The works that have been produced on the nationality question during the Brezhnev years do provide some very useful analysis, yet they often ignore or downplay certain important elements within the nationality question under Brezhnev. 
The historiography of the nationality question under Brezhnev can be broadly divided into two main categories: first, what I will call the "Cold War" approach, and secondly what I would consider the more nuanced approach. Both of these categories have their merits and their shortcomings as do any historical study. These labels will show the primary differences in approach that has been taken regarding the study of the nationality question.

I call the first category the Cold War approach because it is representative of the nature of the works produced by Western historians during the Cold War and of Russian and other exSoviet scholars written both during and after the Cold War. Much of these studies are influenced (whether knowingly or unknowingly) by the ideological rhetorical battle between the West and the Soviet Union during the Cold War. As such, these works most often focus on the repressive nature of the Soviet Union in all aspects, especially in the realm of the nationality question. These studies can be of great value in that they often contain very detailed accounts of the various dissident movements within the Soviet Union after World War II and they examine the regime's response to these movements. However, as with all works of history, they do contain shortcomings. The Cold War approach suffers especially from the lack of an overall perspective. In other words, by focusing almost exclusively on the repressive actions taken by the Soviet regime, this category of the historiography tends to ignore the regime's strategies for dealing with the nationality issue and the rationale for those strategies. Moreover, the Cold War approach, like many of the works of the more nuanced variety, also fails to take into account the foreign policy and economic ramifications of the nationality question during the Brezhnev period.

Perhaps the most thorough study belonging to the Cold War category is Soviet Disunion: A History of the Nationalities Problem in the USSR by Bohdan Nahaylo and Victor Swoboda. 
Basing their arguments largely on samizdat publications, they maintain that the Brezhnev regime's chief goal was to Russify the non-Russians and to do so while hiding behind the rhetoric of building the new "Soviet" man. Nahaylo and Swoboda claim that by the early 1970s the regime's "thinking seems to have been that while the Soviet people was being forged, the Ukrainians and Byelorussians would be moulded to form part of the Russian-speaking Slavic core of this entity." This thinking then explains the severe crackdowns on nationalist dissent in Ukraine and the more lenient attitude toward Central Asia. ${ }^{14}$ Finally, Nahaylo and Swoboda argue that the Brezhnev regime's nationality policy consisted almost entirely of Russification efforts, which explains the official support given to the emerging neo-Slavophile movement among writers as evident in literary journals such as Molodaia gvardiia.

Nahaylo and Swoboda provide an excellent and thorough review of the budding nationalist movements within the Soviet Union during the Brezhnev period as well as of the regime's responses to these movements. And they are correct to point out that much of the Brezhnev regime's approach to the nationality question seems painfully contradictory. After all, promoting proletarian internationalism while also promoting the study of the Russian language would appear to be contradictory. However, as will be discussed later in this chapter, Leninist theories on imperialism and nationality actually provide rationale for such a contradiction. Nahaylo and Swoboda seem to indicate that the Brezhnev regime used repression simply for repression's sake, and there is a kernel of truth to this assertion. But in reality, repression and the concomitant Russification efforts had sound ideological roots.

Closely related to Nahaylo and Swoboda's analysis of nationality issues is Lyudmila Alexeeva's chronicle of nationalist movements Soviet Dissent: Contemporary Movements for National, Religious, and Human Rights. While Alexeeva does not overtly attack the Soviet 
regime as Nahaylo and Swoboda do in their study, she does focus on the various nationalist movements taking place in the Soviet Union during the Brezhnev period and the regime's repressive response to those activities. The value of the studies by Alexeeva and Nahaylo and Swoboda lies in their analysis of the responses of the various Soviet peoples to the policies of the regime. Yet they oversimplify the regime's policies by dismissing them as purely repressive in nature.

Finally, Victor Zaslavsky views the Soviet Union as an empire, but again tends to focus on the repressive qualities of Moscow's nationality policies. Zaslavsky argues that "Prior to Gorbachev, the ruthless suppression of nationalist and separatist movements was the centerpiece of Soviet nationality policy." 15 Zaslavsky does, however, suggest that the repression of nonRussian peoples was accompanied by increasing homogenization of the Union Republics, largely through population transfers. Moreover, he argues that regional inequalities in the Soviet Union began to fade in the 1970s as "the standard of living in the Central Asian and Caucasian republics was higher than that of the industrially developed Russian center."16 He is quick to point out, though, that this was not due to conscious efforts by Gosplan to develop these republics' economies, but rather it was the existence of the black market that raised living standards. Thus, for Zaslavsky, the lot of the non-Russian republics improved not through any conscious efforts from Moscow, but due to black market economics.

Zaslavsky makes some very intriguing points about the imperial nature of the Soviet Union and he is largely correct. However, as with Nahaylo and Swoboda, he misses the point by claiming that repression served as the only tool in the Soviet nationality question toolkit. These authors are most certainly correct in that repression was one of the methods used by Moscow to enforce nationality policy and that Russification was another goal of nationality policy. But 
again, this is an incomplete picture that paints the Brezhnev regime as simply a gang of thugs using brute force to get their way not too unlike mafia godfathers. Indeed, as will be shown, there were other concerns and approaches at play here.

Ben Fowkes perhaps best represents the nuanced approach to the study of the nationality question under Brezhnev. His article "The National Question in the Soviet Union under Leonid Brezhnev: Policy and Response” along with his earlier book The Disintegration of the Soviet Union: A Study in the Rise and Triumph of Nationalism provide a more balanced analysis of the nationality question through seeking to explain some of the regime's rationale behind its nationality policy. Fowkes acknowledges that repression did form a key part of the Brezhnev regime's handling of the nationality question, but he is careful to note that repression was not the only method used. In "The National Question in the Soviet Union”, Fowkes argues that "Leonid Brezhnev pursued a policy of corporatist compromise, ethnic equalization, and masterly inactivity, and this was sufficient to allow the Soviet way of dealing with the national question a few more years of calm, unthreatened existence." ${ }^{\prime 17}$ Thus, Fowkes agrees with the corporatist approach detailed by Valerie Bunce and John Echols. In their article "Soviet Politics in the Brezhnev Era: ‘Pluralism' or 'Corporatism'?”, Bunce and Echols present the clearest description of the Soviet Union's corporatist system during the Brezhnev years. They write that "Essentially, corporatism refers to a decision-making structure in which major functional interest groups are incorporated into the policy process by the state and its leaders." More specifically, Bunce and Echols note that in a pluralist, democratic system, conflict among competing interest groups is the order of the day, whereas in a corporatist system, "consensus and cooperation" among various groups prevails rather than competition. Moreover, in a corporatist system such as that of the Soviet Union during the Brezhnev era, "Groups do not compete with one another 
through the state to obtain more for themselves. Instead, they are brought together by the state in active cooperation to achieve more for all; harmony is the watchword of a corporatist regime."18 Using this approach, Fowkes argues that a policy aimed at achieving compromise prevailed in the Brezhnev regime's approach to the nationality question. Whereas Bunce and Echols maintain that corporatism explains the overall political model for the Brezhnev regime, Fowkes applies this theory specifically to the nationality question in that corporatism "implied striking a compromise between the center and the periphery of the empire. This involved handing over a considerable amount of power to the local elites." 19

Fowkes' argument that the Brezhnev regime sought compromise above all else directly challenges the analyses presented by Nahaylo and Swoboda, Zaslavsky, and others. For example, Fowkes maintains that "The early Brezhnev years saw considerable equalization through inter-republic transfers of wealth and balanced investment" whereas Zaslavsky, it will be recalled, argued that the black market, not conscious efforts on the part of the regime, brought about such equalization. Moreover, Fowkes observes that the Russification efforts as detailed by Nahaylo and Swoboda did not take place evenly across the Soviet Union; rather Russification was more concentrated in Ukraine, Belorussia and Moldova than in Central Asia or the TransCaucasus. $^{20}$

More so than most of the other historians who have studied the Soviet nationality question, Fowkes discusses the Soviet Union in terms of empire and decolonization. In The Disintegration of the Soviet Union, for example, Fowkes argues that by the Brezhnev period, "a non-Russian elite came to the top in the union republics, thus introducing an irreversible process of decolonization within the Soviet Union in the later stages of its existence. The maintenance of the multi-national Soviet empire came to depend on the loyalty of these elites." 21 As a result, 
Fowkes writes, the "dissident national movements of the 1960s and 1970s were not very effective" because their "demands were in practice defused by allowing the titular nations to rule themselves." ${ }^{22}$ This is most applicable in the Muslim Central Asian republics where leaders such as Sharaf Rashidov in Uzbekistan had free reign to do as they wish so long as they paid proper homage to Brezhnev and the Soviet regime in Moscow. In contrast, Brezhnev removed Petro Shelest from his post as Party leader in Ukraine for being too tolerant of Ukrainian nationalism.

Finally, Fowkes writes that the Brezhnev regime did indeed take a more hard-line approach to the language issue after 1977 as "more stress was being laid on the promotion of the Russian language, less on the non-Russian language."23 Overall, however, Fowkes argues that Brezhnev's search for consensus also characterized the regime's approach to the nationality question and that partly because of this policy, a "creeping decolonization" began to penetrate the Soviet Union, particularly in Central Asia. Thus, the regime did not resort exclusively to repression to solve the nationality issue, many more factors were also in consideration.

Throughout the Brezhnev period, the regime consistently promoted the concept of a new "Soviet" nation that in theory meant the end to national differences within the Soviet Union. The regime also celebrated the application of scientific principles in important decision making, especially with regard to economic policies. Some historians dismiss the Soviet nation as mere propaganda whereas others have suggested that there was more substance to this idea. Overall, many of the "nuanced" historians argue that the regime balanced ideological goals with more pragmatic concerns in the area of nationality policy. John Keep suggests that the Soviet man concept was nothing more than propagandistic window dressing as Moscow took a more repressive line against cultural nationalism "that led its exponents to become more active politically, which in turn called forth even tougher police reprisals" yet at the same time the 
regime allowed and encouraged "limited expressions of Russian national consciousness, which in the long run would also help to undermine the system." 24 Above all, however, Keep argues that Brezhnev himself 'took a 'centrist' line between the left-wing zealots, or 'fusionists', and the pragmatists who sought to avoid provoking the minorities by pressing forward too rapidly with the [Soviet nation] grand design."25

The notion of the new Soviet nation presents an obvious contradiction in that the regime promoted the Russian language above the others and the regime's passport policy prevented citizens from choosing "Soviet" as their official nationality. If the "new Soviet man" was the goal, then why must that imaginary character speak Russian and why is that not an option on the internal passport? Keep suggests that the regime promoted the Russian language for pragmatic reasons; every empire needs a lingua franca. As will be shown in Chapter 3, I argue that this language policy was rooted in both pragmatism and in ideology.

As for the coming of the new Soviet nation, this too was rooted in Leninist ideology. Many writings from the early Soviet period make note of the eventual merging of all the nationalities into a single Soviet nation that would be internationalist in its outlook. By the Khrushchev period, the regime proclaimed the coming merger (sliianie) of all the nations into a single Soviet nationality. Brezhnev also used this term early in his tenure. But, as Martha Brill Olcott explains, by the 1970s "official pronouncements carried an implicit acceptance of the continued existence of the multi-national Soviet state with distinct, yet integrated nationalities. After the 1973 reference, the term sliianie disappeared from official parlance and sblizhenie, a term generally used to describe a process which integrates people yet preserves their national uniqueness, came into vogue." 26 The catchphrase by the 1970 s consisted of rastsvet (blossoming) and sblizhenie (rapprochement). In other words, the regime by this point claimed 
that the various nations were able to blossom and develop their own identities while at the same time they would move closer together.

At first glance it seems contradictory that nations could "blossom" and develop further their own identities while at the same time they are moving closer together. And while all this is going on, a new "Soviet man" was being born. Several possible explanations exist for these contradictions. First of all, the Soviet Union was a form of dictatorship in which leaders did not have to explain themselves to the public. But aside from that, Dina Zisserman-Brodsky suggests that pragmatic concerns drove the regime to herald the Soviet nation while continuing to promote the Russian language. She writes that this allowed the Brezhnev regime to preserve "ethnic stratification" which "seems to have been envisaged by the Soviet elite as the most effective safeguard of political stability. ${ }^{27}$ Helene Carrere d'Encausse agrees that pragmatism carried the day, but for a slightly different reason. She argues instead that by the time Brezhnev assumed his leadership position, the Soviet elite believed that they "had accomplished a remarkable historical task by providing for the flowering and equality of the nations. In doing so, it had demonstrated the importance and permanence of the national reality. Trying to weaken the nations, challenging their existence, meant challenging the regime's most notable success." ${ }^{28}$ I would add that the abandonment of the use of the term sliianie by the early 1970s is a direct result of Brezhnev's Developed Socialism doctrine. Developed Socialism allowed Brezhnev to back away from Khrushchev's prediction of communism by 1980 without abandoning the regime's ideological reason for existence. If we extend Developed Socialism to the nationality question, sliianie can be abandoned in favor of a less-radical, more pragmatic goal of allowing the nationalities to develop their identities while following a path toward rapprochement with one another. 
Two basic approaches, then, exist in the historiography of the Soviet nationality question under Brezhnev. The "Cold War" approach tends to emphasize the repressive nature of the Soviet regime and chronicles in great detail the development of the dissident groups within the USSR through the 1960s and 1970s. While this approach has contributed valuable research to the field, it tends to ignore the regime's rationale for its nationality policy and it dismisses the regime's ideological writings as merely pointless propaganda. The nuanced approach correctly acknowledges the repressive nature of the regime while also seeking alternative explanations for the regime's response to the nationality question. Some of the "nuanced" authors such as John Keep or Ben Fowkes take a top-down approach to their studies while others such as Rasma Karklins attempt more of a subaltern analysis. All of these works are valuable to our understanding of the nationality question during the Brezhnev years, yet they also tend to overlook or to ignore completely the many factors affecting nationality policy-making during the Brezhnev years such as the Cold War pressures, economic concerns, and the real ideological basis of the Brezhnev regime's nationality policy.

\section{The Essence of Brezhnev's Anti-Imperialist Empire}

At this point, it is necessary to provide an overview of the major tenets of Brezhnev-era nationality policy. Overall, Brezhnev-era nationality policy chiefly concerned itself with maintaining the Anti-Imperialist Empire - as noted above, the Brezhnev leadership inherited from Khrushchev a reignited decolonization process which itself was a byproduct of deStalinization. To achieve the goal of maintaining the empire, the Brezhnev leadership relied on several basic strategies which I will outline here and discuss in detail in Chapter Three: Trust in Cadres; the concept of Developed Socialism; increasing education and propaganda efforts; and 
the promotion of the study of the Russian language and the related theme of the Great Russians acting as the "elder brother" for the non-Russian peoples. These four themes remain a constant strategy throughout the Brezhnev era, but certain aspects of them, such as the promotion of the Russian language and culture, varied according to the four Soviet Unions model; these efforts were most serious in the Western Soviet Union and then were pursued in lessening degrees in the other Soviet Unions. Motivating and influencing these four basic strategies were the influence of the Soviet Union's ideological heritage and the Soviet Union's foreign policy in the 1960s and 1970s. In terms of foreign policy, Moscow's strong anti-imperialist rhetoric and its constant pronouncements in support of decolonization efforts worldwide led to a "softer" policy in areas such as Central Asia and, to a lesser extent, in Transcaucasia. Closely related to the foreign policy issue is the Soviet Union's effort to forge close ties with the Arab states of the Middle East throughout the Brezhnev era. These efforts also contributed to Moscow taking a more cautious approach in Central Asia when compared to the other Soviet Unions. These issues will be explored in detail in Chapter Three.

I recognize that the use of repression is missing from the outline provided above. In no uncertain terms, the Brezhnev leadership did use repression as one of its tools to maintain the empire. Yet, repression was used to target any form of dissent within the Soviet Union and thus was not specific to the carrying-out of nationality policy. I will refer to the use of repression in Chapter Three, but the evidence indicates that the regime applied repression mainly to dissidents who were few in number and the Brezhnev leadership instead focused more on educational and ideological methods to maintain the empire. I in no way intend to dismiss or downplay the use of repressive tactics; but it should also be remembered that the essence of the Brezhnev leadership was that of peaceful compromise. By Brezhnev's tenure in office, the use of mass 
violence and terror had long since ceased being a viable tool for enacting the regime's policies. Moreover, it is likely that the Brezhnev leadership recognized that the broad use of repressive tactics would have gone too far in upsetting the apple cart; they were satisfied with relying on less-forceful means for maintaining the empire. Brezhnev's tactics certainly did not solve the nationality issue, but they did succeed in keeping the peace until Gorbachev unintentionally opened the nationality can of worms in the 1980 s.

When Brezhnev took office in October 1964, he immediately set about reversing some of Khrushchev's more radical policies. This is especially true in respect to those policies relating to the Communist Party and its personnel. Moreover, the top echelon of the Party specifically chose Brezhnev to replace Khrushchev because of Brezhnev's reputation as a congenial man who sought compromise over conflict, slow, reasoned change over brash, hasty change. Brezhnev's style is evident when in October 1964 he laid out his plans that have become known to historians as the "trust in cadres" policy. William Tompson notes that at the October 1964 Party Plenum, "it is noteworthy that Brezhnev stressed not the leading role of the party but the leading role of party organs. He promised more than once to 'stick up for cadres', beginning to develop the themes of 'trust in cadres' and 'stability of cadres'..." 29 At the most basic level, "trust in cadres" essentially translated into enhanced job security for Party officials at all levels. Brezhnev's insistence on "trust in cadres" ensured greater stability in the Party ranks and therefore a greatly reduced level of job turnover among Party officials. In one respect, this idea is a rejection of Khrushchev's policies. One of the biggest complaints against Khrushchev had been his proposal of forced retirement for Party officials upon reaching a certain age. Brezhnev immediately reversed Khrushchev's term limit policy in favor of "trust in cadres." Most importantly for Brezhnev's personal political security, the stability of cadres ensured that 
Brezhnev would acquire and maintain a rather large base of support from within the Party especially from those Party officials serving in the republic and local Party committees. Most likely, this was Brezhnev's primary goal. But, as Tompson points out, the stability of cadres concept "both reduced the scope for introducing new people - and hence new ideas - into the leadership and created greater opportunities for corruption that had previously existed, particularly in outlying republics with long-serving leaders. ${ }^{30}$ Thus, Brezhnev's promise of job security to his Party colleagues in some sense created a certain air of stagnation in that Party members from the Kremlin on down to the oblast committees aged along with Brezhnev and it did do much to prevent the entrance of new ideas into the Party and its leadership. However, for the purposes of this study, trust in cadres allowed republic leaders to remain in office for long periods of time, especially in Central Asia. As will be discussed in Chapter Three, these longtenured republic leaders were the ones who had to operate in the conditions of the reignited decolonization process, again, especially in Central Asia. As a result, these leaders often functioned as the intermediaries between Moscow and the developing decolonization processes in their respective republics, which often led to these leaders seeking to harness the forces of nationalism and decolonization thereby causing them to at times seek to oppose certain aspects of Moscow's policies. It also led to rampant corruption, much of which went uncovered until the Gorbachev years.

If trust in cadres contributed to the reignited decolonization process in many areas of the Soviet Union, then Brezhnev's concept of Developed Socialism in part worked to try to counterbalance decolonization. At the $24^{\text {th }}$ Party Congress held in Spring 1971, Brezhnev officially introduced the concept of Developed Socialism. While this is not a major shift in the Communist Party's ideological outlook, it is an important revision that sought to explain the 
then-current stage of Soviet development in Marxist-Leninist terms. Developed Socialism primarily concerns the level of economic development reached in the Soviet Union by the early 1970s, but in some ways it also was carried over into other areas of the Soviet Union, particularly in the emphasis placed on scientific decision-making and in the realm of nationality affairs. In essence, Developed Socialism sought to scale back Khrushchev's famous declaration that the Soviet Union would achieve communism by 1980 . Firmly rooted in Marxist-Leninist theory, the concept of Developed Socialism allowed Brezhnev to postpone the Soviet Union's arrival to the communist stage of history while still allowing the regime to tout the economic advancements of the country and to retain the Soviet Union's leadership of the global Communist movement. While Brezhnev intended Developed Socialism primarily for the economic realm, it did have great implications regarding nationality policy. Developed Socialism marked the regime's turn toward a more "conservative" nationality policy outlook and it provided further ideological basis for the Brezhnev leadership's attempts at further consolidating the empire to counteract the forces of decolonization. Developed Socialism culminated in the passage of the new Soviet Constitution in 1977; sometimes referred to as the Brezhnev Constitution. As will be discussed in Chapter Three, the 1977 Constitution was drafted to reflect the Soviet Union's status as an advanced socialist country, preparing for the building of communism. What this meant for nationality policy is that the Constitution sought to consolidate further the Soviet Empire in part through new language policies, but these efforts had to be abandoned after popular protest.

The Brezhnev leadership relied most on education and propaganda to pursue its imperial maintenance strategy. The pages of the Soviet press, the speeches delivered at all-Union and republic-level Party congresses, and the pages of academic journals and books are full of 
pronouncements on the need to further educate the working class on the merits of proletarian internationalism and the need to eradicate the remnants of feudal-bey customs in Central Asia or the bourgeois Ukrainian nationalist lackeys of American imperialism. Chapter Three will demonstrate that the nature of education and propaganda changed over time during the Brezhnev era, essentially growing more conservative by the 1970s. Moreover, the rhetoric promoting the further study of the Russian language by non-Russians and the idea of the Great Russians as the "elder brothers" of the non-Russian peoples intensifies as time progresses. Finally, as will be discussed in the next chapter, subtle differences in this sort of rhetoric can be observed within the transcripts of the various Party congresses at the republic level. The Brezhnev leadership's pronouncements regarding education and the promotion of the Russian language reveal the Kremlin's growing concern for the decolonization process, particularly in Central Asia. Rather than resort to mass terror of the Stalinist variety, the Brezhnev leadership instead relied on intensifying the propaganda in an effort to educate the masses on the merits of Leninist nationality policy and the dangers of bourgeois nationalism.

These four strategies, then, formed the basic core of Brezhnev-era nationality policy. Moreover, foreign policy concerns - most notably the Soviet Union's involvement in the Middle East and the 1979 invasion of Afghanistan - had important nationality policy ramifications. One of the key purposes of the present study is to show that nationality policy in the Soviet Union did not occur in a vacuum; the Cold War did much to influence thinking in this policy realm. Finally, although the Brezhnev leadership did adopt the four-prong approach to the nationality issue as outlined above, it should always be remembered that nationality policy was always of secondary concern to the Soviet leadership. As I stated earlier, Stalin was the last Soviet leader who devoted considerable time to the "resolution" of the nationality question. Despite the fact 
that the Brezhnev leadership made countless speeches regarding nationalities, their overriding concerns were the economic development of the Soviet Union and the foreign policy concerns posed by the Cold War.

Before delving in to a detailed analysis of Brezhnev-era nationality policy, it is necessary to gain an understanding of the theoretical roots of the Brezhnev leadership's strategies. The next section examines the ideology behind Soviet thinking on issues such as the nation, nationalism, and imperialism. The point will be to demonstrate that the concepts discussed in Chapter Three are largely based on sound Marxist-Leninist ideals - therefore while Soviet nationality policies appear to us as imperialistic, to the Soviet leadership they were anything but imperialistic.

\section{The Theoretical Roots of Brezhnev's Anti-Imperialist Empire}

In a speech to the Conference of European Communist and Workers' Parties in April 1967, Brezhnev stated that "the threat to peace in Europe is brought by the aggressive forces of American and West German imperialism" [my emphasis added]. ${ }^{31}$ This statement is typical of Soviet officials throughout the Cold War; the denunciation of imperialism (usually American imperialism) is a common theme in official statements. But the reference to "West German imperialism" seems odd when considering traditional Western ideas of empire and imperialism. Based on the definition of empire discussed in Chapter One, it would appear that West Germany is a decidedly unlikely candidate for the imperial label. West Germany, after all, was one of the tidy nation-states of Western Europe with no colonial possessions. Even by 1967, it was becoming increasingly difficult to label West Germany's neighbor France as imperialist as it was then in the process of relinquishing control over most of its former imperial possessions. 
To be sure, there is an element of propaganda in Brezhnev's statement: he followed up his proclamation with the observation that "American imperialism is in collusion with the ruling circles of the FRG..."32 Moreover, he argued in this speech that the West Germans, unlike their socialist counterparts in the GDR, had failed to rid their country of Nazi elements, which meant that German militarism lives on in West Germany aided by their American imperialist allies. But more than propaganda is evident in Brezhnev's speech. Imperialism is a common theme in not only Brezhnev's speeches and writings during this period, but in all sorts of Soviet literature. A key part of this is due to propaganda, but a larger part is due to the Marxist-Leninist ideological heritage. In this section, I will review the relevant works of Lenin and Stalin on questions of the nation and imperialism and then compare these views with Western, nonMarxist-Leninist positions on these important issues. The purpose here is to show that the Soviet leadership had slightly different views on the nation and imperialism, which does much to help explain the rationale of the Anti-Imperialist Empire.

Marxism and Marxism-Leninism, it is well known, are ideologies rooted in economics and class conflict. To the Marxist, human history can be understood primarily through investigating the economic relations between classes in a given society. Moreover, Marxism has always declared itself as scientific - Karl Marx claimed to have discovered the scientific nature of history in that history naturally moves through stages based on economic relations and conflicts between classes. Therefore, a key way in which Marxist and non-Marxist analyses of the nation differ is that Marxism and Marxism-Leninism claim that the nation and nationalism are only temporary phases of bourgeois class ideology and that they will decline with the international development of capitalism. 
A common idea in most Western analyses of the nation is that the nation exists first and foremost in the imagination of its members. Benedict Anderson, for example, writes that a nation "is an imagined political community - an imagined as both inherently limited and sovereign." He argues further that the nation is "imagined because the members of even the smallest nation will never know most of their fellow-members, meet them, or even hear of them, yet in the minds of each lives the image of their communion." Anderson states that the nation is "imagined as limited because even the largest of them, encompassing perhaps a billion living human beings, has finite, if elastic, boundaries, beyond which lie other nations. No nation imagines itself coterminous with mankind." Finally, Anderson reminds us that the nation is imagined as a community "because, regardless of the actual inequality and exploitation that may prevail in each, the nation is always conceived as a deep, horizontal comradeship."33

Whereas much of the Western discourse on the nation tends to focus on the imaginary nature of the community, Soviet discourse is based on a more concrete definition of the nation. In 1913, Stalin wrote his famous essay "Marxism and the National Question" in which he formulates a definition of the nation and he explains how Marxism should properly deal with the nation and the forces of nationalism. The theories Stalin outlined in this essay formed the ideological basis of Soviet nationality policy and are readily apparent in the writings produced during the Brezhnev era. This essay, along with Lenin's writings, provides the basic Soviet worldview on the nation, the development of the nation, and the future course of national development.

Stalin defined the nation as "a historically constituted, stable community of people, formed on the basis of a common language, territory, economic life, and psychological make-up manifested in a common culture... it is sufficient for a single one of these characteristics to be 
lacking and the nation ceases to be a nation." ${ }^{34}$ Stalin did not explicitly reject the imaginary features of the nation, but he did shy away from it when he wrote that "a nation is not a casual or ephemeral conglomeration, but a stable community of people." ${ }^{35}$ Moreover, his prior statement regarding the "psychological make-up manifested in a common culture" is not an admission of the nation as an "imagined community" as he does not indicate that the common culture is something that is manufactured artificially over a relatively short period of time. Further evidence that Stalin did not endorse the imaginary qualities of the nation can be seen in his claim that historically the Georgians did not constitute a nation because they were "split up into a number of disconnected principalities, they could not share a common economic life..."36 Finally, Stalin declared that the Russian, Galician, American, Georgian, and Caucasian Highland Jews could not constitute a nation because they lacked common economic ties as well as a common homeland and language.

For Stalin, then, a nation can only exist if it shares a common culture, common territory, common economic ties, and a common language, among other shared attributes. It is also a community that has arisen only during the capitalist stage of history and it will continue into the socialist stage of history. This then raises the issue of the future of the nation, particularly what will happen to the nation after the elimination of the bourgeoisie and the nation enters into socialism. Both Stalin and Lenin offered explanations for this process. Above all, Stalin and Lenin emphasized the importance of national self-determination. Stalin wrote that "the right of self-determination is an essential element in the solution of the national question" because a minority nation "is discontented not because there is no national union but because it does not enjoy the right to use its native language. Permit it to use its native language and the discontent will pass of itself." Even more, Stalin argued that national self-determination will not lead to 
outbreaks of nationalism or national oppression. He explained that regional autonomy may create the fear that "the minorities will be oppressed by the national majorities" but "give the country complete democracy and all grounds for fear will vanish." ${ }^{37}$ In other words, the conditions of class conflict under capitalism is what breeds nationalism and national oppression; under conditions of socialism, or "complete democracy", the causes of such hatreds will disappear, although the nations themselves will continue to persist.

More so than Stalin, Lenin expounded upon the future of the nation under socialism. In his essay "Critical Remarks on the National Question", Lenin wrote in 1913 that the "slogan of national culture is a bourgeois (and often also a Black Hundred and clerical) fraud. Our slogan is: the international culture of democracy and of the world working-class movement." ${ }^{38}$ The main focus of Lenin's essay is that of the assimilation of nations. He argues that even under capitalism, the world's nations were already going through a process of assimilation. This will continue under socialism. Lenin states that "Even if we assume that, in time, there will be a state frontier between Great Russia and Ukraine, the historically progressive nature of the 'assimilation' of the Great-Russian and Ukrainian workers will be as undoubted as the progressive nature of the grinding down of nations in America." More specifically, Lenin explains that "If the majority of the Ukrainian workers are under the influence of Great-Russian culture, we also know definitely that the ideas of Great-Russian democracy and Social Democracy operate parallel with the Great-Russian clerical and bourgeois culture. In fighting the latter kind of 'culture', the Ukrainian Marxist will always bring the former into focus and say to his workers: 'We must snatch at, make use of, and develop to the utmost every opportunity for intercourse with the Great-Russian class-conscious workers, with their literature and with their range of ideas..." But is this not Great Russian chauvinism, which Lenin constantly denounced 
as bourgeois nationalism? No, because, as Lenin explains, if a "Ukrainian Marxist allows himself to be swayed by his quite legitimate and natural hatred of the Great-Russian oppressors to such a degree that he transfers even a particle of this hatred...then such a Marxist will get bogged down in bourgeois nationalism. Similarly, the Great Russian Marxists will be bogged down...if he loses sight, even for a moment, of the demand for complete equality for the Ukrainians, or of their right to form an independent state." ${ }^{39}$ Finally, Lenin argues that the proletariat "supports everything that makes the ties between nationalities closer and closer, or tends to merge nations." ${ }^{40}$ Thus, because nationalism is only possible under the conditions of capitalism, nations naturally will assimilate under conditions of socialism. Under socialism, all nations are equal in stature, but they differ in their levels of development. Less-advanced nations will naturally assimilate the progressive qualities of the more advanced nations, which is why the peoples of the Soviet Union, it is reasoned, will voluntarily assimilate the progressive qualities of the Russian nation and will desire to speak their tongue.

In 1914, Lenin wrote "Is a Compulsory Official Language Needed?" In this essay, Lenin stated that "the closest possible intercourse and fraternal unity should be established between the oppressed classes of all the nations that inhabit Russia, without any discrimination. And we, of course, are in favor of every inhabitant of Russia having the opportunity to learn the great Russian language" [emphasis added]. ${ }^{41}$ Lenin is very careful, however, to point out that there should be no compulsory learning of the Russian language on the part of the non-Russian peoples. Rather, he is stating that in Russia, capitalism is "tending to bring all nations closer together" and this process will only continue once socialism is established. Again, the emphasis is that because the Russians are the most progressive (i.e., are the leading Marxists in the country), the non-Russian peoples will naturally and voluntarily acquire the progressive qualities 
of the Russian nation, including the Russian language. This thesis will, of course, be a guiding principle in Soviet nationality policy, particularly during the Brezhnev era. Brezhnev-era Russian language promotion and policies were simply viewed by the leadership as the fulfillment of Leninist prophecy - the peoples are voluntarily assimilating and learning Russian. Unfortunately during the Brezhnev era, realities on the ground did not match Lenin's predictions. In 1929, Stalin further theorized on the state of nations and their future under the conditions of socialism. In his essay "The National Question and Leninism", Stalin argued that "with the elimination of capitalism, the old bourgeois nations will be eliminated." But this does not mean the immediate disappearance of nations, rather, new, Soviet nations took the place of the old bourgeois nations. "National oppression", Stalin wrote in 1929, "in our country was abolished long ago, but it by no means follows from this that national differences have disappeared and that nations in our country have been eliminated." What's more, Stalin continued, "I affirmed (and continue to affirm) that the period of the victory of socialism in one country does not create the necessary conditions for the merging of nations and national languages, that, on the contrary, this period creates favorable conditions for the renaissance and flourishing of the nations that were formerly oppressed by tsarist imperialism and have now been liberated from national oppression by the Soviet revolution." ${ }^{, 2}$ Furthermore, Stalin cautions that to "attempt to bring about the merging of nations by decree from above, by compulsion, would be playing into the hands of the imperialists, it would spell disaster to the cause of the liberation of nations." ${ }^{43}$ Stalin's use of terror notwithstanding, successive Soviet regimes relied primarily on education to achieve these goals.

Soviet views on the nation, then, based on the works of Stalin and Lenin, emphasized the scientific, concrete nature of the nation. Unlike many Western views, Soviet analyses of the 
nation downplayed the imaginary nature of the nation in favor of more concrete characteristics such as common territory, language, and economic ties. Soviet analyses also pointed out that nations undergo change, particularly the changes associated with the transition from capitalism to socialism. But the primary point to make is that according to the Soviet worldview, nations under socialism will naturally assimilate the qualities of the more advanced nation and they will naturally merge together. Thus, the Brezhnev-era discourse on the Soviet man should not be dismissed as mere propaganda. Soviet ideology taught that such a "nation" would eventually emerge in the advanced stages of socialism and that all national aspects, along with class distinctions and the state, would wither away in the transition to communism. However, as will be discussed later, Brezhnev-era discourse was contradictory on the issue of the Soviet nationoften it was implied that the Soviet man already existed, whereas in other speeches or writings, it seemed as if the Soviet man would arrive at a later date, perhaps on the eve of the arrival of communism.

Naturally, the precepts set forth by Stalin and Lenin on the nation and on the resolution of the nationality question continued into the Brezhnev era. Brezhnev-era theorists continued to debate and refine the theories set down by Stalin and Lenin. Vivid evidence of this discourse can be seen in the pages of the Soviet journal Voprosy Istorii from the mid 1960s to the early 1970s. The theoretical arguments and debates that appeared in these issues provide a glimpse into the contemporary thinking among Soviet academics on the important issue of the nation and national relations. And because they were published, these ideas received at least tacit approval from elements in the power structure.

In his 1967 article "Nekotorye Problemy Teorii Natsii” [Certain Problems on the Theory of the Nation], academic V.I. Kozlov further refined the definitions of the nation as outlined 
above by Stalin. Citing the need for further research into the theory of the nation, Kozlov stated that "a nation is not simply a group of people, but a large group of people. If the average number of a tribe [plemia] measures itself by a few hundred or thousand persons, then the average number of a nation measures hundreds of thousands or millions of persons, for only such measures of them are able to ensure internal divisions of labor, corresponding development methods of production [and] of particular importance in these relations, in our opinion, is the founding of a national intelligentsia." ${ }^{44}$ The crux of Kozlov's argument, however, is the importance of economic connections and political centralization to the development of a nation, while downplaying the significance of a common territory in defining the nation. For Kozlov, "economic commonality of the nation means the economic connection of all parts of the nation in a united economic whole, the union of its local markets with the overall national market." Therefore, according to Kozlov, "The nation is a social category arising in the capitalist epoch and for capitalism, the characteristic development of economic connections, and the rise of the population's economic commonality." ${ }^{45}$

As an example of the importance of economic connections to the formation of the nation, Kozlov cites the history of the non-Russian peoples in comparison to their Russian counterparts. He notes that Russian national formation "as with the major peoples of Western Europe, followed the path of political centralization of separate formerly independent lands accompanied by the establishment of close economic and cultural connections among the Russians." However, Kozlov explains, "as for the other peoples of Russia, their development acquired highly specific forms. The slow pace of social-economic development of the majority of the peoples of Russia and the state-economic connections of them with the ruling nation and with 
each other impeded the process of the development of the peripheral (in terms of their relations with the Great Russians) nations..."46

Here, then, Kozlov continues Stalin's emphasis on the importance of economic relations in the formation of nations. Moreover, Kozlov provides evidence that the Russians were more advanced than the other peoples of the Russian Empire, at least in terms of economic development. This, then, continues the theme outlined by Lenin that the nations of the former tsarist empire would naturally assimilate qualities of the more advanced nation. The Russians were the more advanced nation, according to Kozlov. The lack of proper economic relations impeded the formation of the nation among the non-Russian peoples.

Kozlov takes his argument a step further by analyzing the current circumstances in the Soviet Union. He notes that "At present, it would be strange to look for some Tatar or, for example, Bashkir economic community that is different from the economic community of the Russian population of the same territory. It would be wrong to define the internal economic relations and the internal markets of the USSR population only by natural boundaries..."

[emphasis added]. ${ }^{47}$ This last statement is significant because Kozlov is suggesting that the Soviet Union in 1967 had reached a sufficient stage in its socialist economic development to begin to render boundaries (i.e., those between Union Republics or those delineating ASSRs, etc.) irrelevant. Although Kozlov does not state this, the growing irrelevancy of boundaries is a phase in the development of a Soviet nation. If the peoples of the USSR have become so economically integrated with one another as to make boundaries increasingly irrelevant, then the Soviet nations must be entering the process of their merging into a single nationality, though presumably this would still be sometime in the future. But it does provide a theoretical rationale 
for the Brezhnev leadership's consistent promotion of Russian-language education in the nonRussian regions.

A common theme in the Soviet discourse on the nation is that of the evolutionary nature of national development. In his article "Natsiia kak Sotsial'no-etnisheskaia Obshchnost' Liudei" [The Nation as a Social-Ethnic Community of People], M.S. Dzhunusov borrows heavily from Stalin's definition of the nation when he writes, "the nation is a large group of people distinguished by a stable community of language, ethnic territory, national identity and specific national features of culture and character that evolved during the formation of both capitalist and socialist economic relations. $" 48$ Just as Stalin had suggested in 1929, Dzhunusov argues that "Nations are structural elements of the capitalist socio-economic formation and of the first period of the establishment of the global communist socio-economic formation."49 However, Dzhunusov expands upon this definition of the nation by outlining the evolutionary path of the development of the nation. He states that the "categories of 'tribe', 'nationality' [narodnost'], and 'nation' express the stages of development of an ethnic society of people. Between them are not only differences, but also commonalities." In essence, according to Dzhunusov, the nation has its origins as a family-based clan, which then becomes a tribe once it has achieved a suitable size. The tribe has its own territory, cultural rituals, religious ceremonies, and presumably its own language. With time, Dzhunusov states, the tribe may grow into a nationality and from there, into a nation. Population seems to be the only factor distinguishing a tribe from a nationality and a nationality from a nation: "Thus, if a tribe numbers one or two thousand...then the nationality consists of 10,000 or a million people. Contemporary nations include ten or a hundred million.",50 
Dzhunusov's numbers appear arbitrary to be sure, but he does highlight a very important characteristic of the Soviet view of the nation - the development of the nation is an evolutionary process not unlike that of the entire course of human history as outlined in Marxism. As Marx concluded that history evolves through stages driven by class conflict, the nation too evolves through stages, in this case from tribe to nation. Dzhunusov agrees with Kozlov in that economic relations within the nation are crucial to that nation's development. Moreover, Dzhunusov notes that "During the transition from a tribal society of people to a nationality and from there to a nation, there is not lost the characteristic signs of all types of ethnic societies (language, ethnic territory, ethnic consciousness, etc.)." Likewise, when a nation transforms from a bourgeois to a socialist nation, it still does not initially lose its national characteristics. ${ }^{51}$ Ultimately, under socialism, the Soviet nations will continue to evolve into still higher national formations. Dzhunusov writes that the "Soviet socialist economy simultaneously is the base for the development of such multinational social communities of people as the Soviet people [sovetskii narod] and for the development of national communities of people (nations and nationalities). The commonality of economic life in all Soviet nations and nationalities appears as the largest part of the highest community of people - the Soviet people." ${ }^{.52}$

Thus, in Dzhunusov's view, national development is teleological - the deepening economic ties developing among the peoples of the Soviet Union under the conditions of advanced socialism will result in the formation of an all-encompassing nation, the Soviet nation. And, as Lenin had indicated, should this Soviet nation take shape, Russian would likely be its language as it is the language of the most advanced of the Soviet peoples.

Language plays a vital role in the evolution of nations, according to the Soviet discourse of the Brezhnev era. In his article "Nekotorye Voprosy Poniatiia 'Natsiia"' [Certain Issues in the 
Understanding of the Nation], N.A. Tavakalian notes that the "socialist nation inherits all the characteristic preconditions of the bourgeois nation. But these, especially the economic community and the national character, undergo radical changes and become completely filled with other contents that acquire a new quality in connection with the character of the building of socialism." Of crucial importance, Tavakalian states that "the socialist nation does not create for itself a new national language [that is] completely different from the language of its predecessors the bourgeois nation or nationality." Instead of the national language going through fundamental change in the transition from capitalism to socialism, "the language of socialist nations is continually enriched in accordance with the themes of gigantic progress which continuously takes place in all areas of science and technology..." This linguistic enrichment takes place, according to Tavakalian, through the "logical process of the mutual influence of languages. Thus the main and basic source of such enrichment in our country is the rich and mighty language of the Great Russian people, particularly for the so-called recently literate [mladopis 'mennyi] peoples. In these languages there are many words borrowed from the Russian language." 53 Under socialism, languages "draw together" [sliianie] "naturally giving rise to the need and desire to voluntarily study the Russian language, which has become in the USSR an international language and a second language for the non-Russian nations.. ${ }^{\text {, }}$ Again, Lenin predicted this would happen as the nations under socialism would naturally be drawn to the more advanced nation.

It should be noted that the theoretical articles in Voprosy Istorii grew increasingly conservative through the late 1960s and early 1970s. Articles published from 1964 to about 1967-68 are of a less-propagandistic nature whereas by 1970, these articles are using the same terminology as the writings and speeches made by the Brezhnev leadership. Therefore, I 
recognize that the articles discussed above do contain a sharp element of propaganda. However, they should not be dismissed as mere propaganda, nor should the public pronouncements of the Brezhnev leadership be dismissed as such. It should be remembered that the Communist Party always stressed the importance of propaganda for educating the masses even before the October Revolution. Therefore, propaganda in the Soviet sense of the term differs from the Western sense - in the West, the term carries a negative connotation implying that it is nothing more than window-dressing by the progenitor of the message. But in the Soviet Union, propaganda was seen as a form of education and of carrying the Party's message and ideology to the people. To be sure, the Brezhnev leadership did use this kind of propaganda to paper over the shortcomings in its nationality policy and as a cover for some of the more repressive aspects of that policy. But at the same time, the Brezhnev leadership believed in the ideological message. Based on the theoretical arguments outlined above, the Brezhnev leadership did not view such actions as promoting the study of the Russian language as imperialistic. Rather, language policy was part of the ongoing task of building socialism and the start of the new task of building communism. Unfortunately, however, the ideology did not match the realities that the leadership faced.

Just as Soviet views of the nation differed from the common Western view, the Soviet definition of imperialism also bears striking differences. Western discourse on empire and imperialism, as indicated in Chapter One, focuses on the relations between the metropole and the periphery; essentially an empire is an entity in which a central government rules directly over a number of peripheral regions which may be contiguous to the central heartland - as in the case of land-based empires like the Ottoman or Soviet empires - or these regions may be scattered across the globe as exemplified by the British or French empires. Western discourse also recognizes the existence of informal empires - those in which the imperial regime may not have 
direct political control of the periphery, but it does dominate the periphery's economy or foreign policy, etc. Soviet discourse on empire and imperialism agrees with that of the West on these basic issues, but it also tightly links imperialism to economics, particularly capitalism.

Soviet discourse on imperialism is based on Lenin's famous pamphlet Imperialism as the Highest Stage of Capitalism written in 1916 during the throes of World War One and on the eve of the 1917 Russian Revolution. In this essay, Lenin explicitly links imperialism to advanced capitalism. Lenin argues that capitalism itself moves through stages, chiefly it evolves from what Lenin called the stage of completely free enterprise during which relatively small business concerns dominated, to the stage of monopoly capitalism during which large cartels dominate their respective industries. He states that the transition from free enterprise to monopoly capitalism occurred in the nineteenth century: "the principal stages in the history of monopolies are the following: 1) 1860-70, the highest stage, the apex of development of free competition; monopoly is in the barely discernible, embryonic stage. 2) After the crisis of 1873, a wide zone of development of cartels; but they are still the exception. They are not yet durable. They are still a transitory phenomenon. 3) The boom at the end of the nineteenth century and the crisis of 1900-03. Cartels become one of the foundations of the whole of economic life. Capitalism has been transformed into imperialism." ${ }^{55}$ Monopoly capitalism, in Lenin's mind, manifests itself in the form of imperialism. Ironically, Lenin argues that monopoly capitalism results in the "complete socialization of production" as the means of production become increasingly concentrated into the hands of only a select few. Presumably, this then paves the way for socialism.

Lenin argues further that monopoly capitalism gives rise to the concentration of banking, or the development of finance capital, which is also increasingly monopolized. It is the rise of 
finance capital that leads to imperialism, which is the highest stage of capitalism. Because not all of the finance capital can be invested in the home country and produce the desired level of profit, Lenin argues that the finance capitalists turn to investing their capital into the resourcerich, yet undeveloped parts of the world. Imperialism, then, is the act of finance capitalists seeking to enhance their profits. As proof, Lenin argues that "four of the richest capitalist countries" control "securities to amounts ranging from 100 to 150 billion francs. Two of these countries, England and France, are the oldest capitalist countries, and, as we shall see, possess the most colonies; the other two, the United States and Germany, are in the front rank as regards rapidity of development and the degree of extension of capitalist monopolies in industry."56 Thus, according to Lenin, "It is beyond doubt, therefore, that capitalism's transition to the stage of monopoly capitalism, to finance capital, is bound up with the intensification of the struggle for the partition of the world." 57 Lenin sums up his argument with his own definition of imperialism. He writes, "Imperialism is capitalism in that stage of development in which the dominance of monopolies and finance capital has established itself; in which the export of capital has acquired pronounced importance; in which the division of the world among the international trusts has begun; in which the division of all territories of the globe among the great capitalist powers has been completed." ${ }^{, 58}$ Imperialism, then, is a manifestation of capitalism in its most advanced stage; the stage of monopoly capitalism.

Lenin's theory on the development of imperialism suggests that modern imperialism can only arise under the conditions of advanced capitalism. Therefore, socialist countries cannot be classified as imperialist. Because, as Lenin theorized, modern imperialism is predicated upon the economic exploitation of colonial possessions by finance capital, a socialist state like the Soviet Union in theory cannot be called imperialist because it lacks finance capital; it has moved on 
from advanced capitalism into the stage of building socialism. Additionally, the Soviet Union in theory did not exploit colonial possessions; indeed during the Brezhnev era, Central Asian leaders considered it a "patriotic duty" to deliver cotton to the rest of the USSR. Only advanced capitalist countries can practice imperialism, according to Lenin's theory and the overall Soviet discourse. This is why Brezhnev in his speech to the European Communist and Workers' Parties could call West Germany an imperialist country, even though it lacked colonial possessions. According to Soviet discourse, based on Lenin's teaching, West German capitalism had achieved the stage of advanced capitalism and, naturally, West Germany was in cahoots with the American imperialists.

Again, it should be noted that propaganda did play a role in the Soviet discourse on the nation, nationalism, the heralding of the Great Russians, and imperialism. In the midst of the Cold War, the Soviet leadership had to make such pronouncements to win allies in the competition with the United States. Yet the Soviet discourse on the nation and especially on the promotion of the Russian language and of the Great Russians as the "elder brothers" did have a firm Marxist-Leninist ideological basis. What appeared as Russification (or imperialism) to outsiders or internal dissidents was regarded by the Soviet leadership as the natural progression of history as detailed by Marx and Lenin and serves as the Soviet Empire's civilizing mission. This, then, is the essence of the Anti-Imperialist Empire - the Marxist-Leninist approach to nationality affairs taught that nations naturally would come together and acquire the best qualities of the most advanced nation while bourgeois nationalism disappeared. Under the conditions of capitalism, such policies and processes would be imperialist, but under the conditions of socialism, they are decidedly anti-imperialist. 


\section{CHAPTER THREE}

\section{DEVELOPED SOCIALISM AS SOVIET IMPERIALISM}

\section{Introduction}

In 1964, in one of his first major speeches as Chairman of the CPSU, Leonid Brezhnev declared "The national problem - one of the most acute and difficult problems that we inherited from capitalism - has been successfully resolved in our country. Now all the nations and peoples of our country live as a single, fraternal family." ${ }^{1}$ Yet, over the next eighteen years, the Brezhnev leadership would continue to work to resolve the nationality problem in the Soviet Union. Although the nationality problem remained unresolved at the time of Brezhnev's death in November, 1982, he may have been the most successful of all Soviet leaders in handling this complicated issue. Yet, Brezhnev's strategy for maintaining the Soviet Empire ultimately contributed to the unravelling of the empire during the Gorbachev years.

This chapter addresses the primary components of the Brezhnev leadership's efforts to keep a handle on the Soviet nationality problem and thereby to maintain the Soviet Empire. It begins with an overview of the situation the Brezhnev leadership inherited from Khrushchev in 1964 and discuss the ways in which the new Brezhnev leadership maintained some of Khrushchev's policies while discarding others. Essentially, the Brezhnev leadership retreated from certain of Khrushchev's more ambitious policy statements while keeping intact many of Khrushchev's policies in this realm.

By the late 1960s, however, a shift in policy is apparent regarding the nationality problem. The Party's rhetoric promoting the Russian language and the Russian people as first among equals is stepped up along with more forceful calls to educate the Soviet people in a true 
internationalist fashion. This stage is the prelude to the theory of Developed Socialism, formally introduced by Brezhnev at the $24^{\text {th }}$ CPSU Congress in 1971. As will be demonstrated in this chapter, Developed Socialism forms the crux of Brezhnev's strategy of maintaining the Soviet Empire. Though Developed Socialism was primarily intended as an economic theory and as a careful way to step back from Khrushchev's earlier grandiose pronouncements, it is also indirectly applied to the nationality problem. Developed Socialism really meant a further consolidation of the Soviet Empire at the expense of Union Republic sovereignty. Because Developed Socialism as a theory is so significant to understanding the Brezhnev era (yet it tends to be overlooked in the historiography), the bulk of this chapter will be devoted to discussing and analyzing this theory. I will explain the primary components of Developed Socialism based on the writings of prominent Soviet officials and theorists. In the next chapter, I will then demonstrate how Developed Socialism was applied to the nationality problem. Developed Socialism in practice culminated in the ratification of the new USSR Constitution in 1977 and new Union Republic constitutions in 1978. Extensive discussion of these new constitutions in the next chapter will reveal that the ultimate goal of Developed Socialism, and of the Brezhnev leadership, was further consolidation of the Soviet Empire at the expense of republic sovereignty, yet rooted firmly in Leninist doctrine.

Throughout these discussions, I will be mindful of the continued existence of regional diversity in terms of nationality policy as well as of the developing decolonization process taking shape in the Soviet Union through the 1970s. These issues will be added to the analysis as they become relevant. Moreover, the foreign policy component of Soviet nationality policy will be analyzed as well, especially as it concerns the continuance of regional diversity in nationality policy. 
It should be stressed again, however, that as with the other Soviet leaders after the 1930s, nationality policy appeared to be of secondary importance to the Brezhnev leadership. There is no document or speech in which Brezhnev or his colleagues explicitly declare the official nationality policy. Instead, nationality policy during the Brezhnev period is the byproduct of the historical legacy inherited from the previous five decades, the immediate legacy of Khrushchev and the circumstances of his removal from office, and, most importantly, of the issues confronting the Soviet Union in the 1960s and 1970s such as the country's economic conditions, foreign policy concerns, and Party policies. Because there is no official roadmap for addressing the nationality issue, some contradictions arise and on occasion the Brezhnev leadership is forced to retreat from pursuing certain of its stated goals. Such problems will be addressed in this chapter as they arise.

\section{Khrushchev's Legacy}

As noted in Chapter Two, Khrushchev's approach to the nationality issue consisted of a measure of decentralization particularly in the form of the sovnarkhozy while also calling for the rapprochement [sblizhenie] and fusion [sliianie] of the nationalities. In addition, Khrushchev proclaimed the coming of the Soviet man and he promoted the use of the Russian language as the lingua franca of the Soviet Union. Until 1971, the Brezhnev leadership mostly kept Khrushchev's policies intact. The Soviet man continued to be promoted in speeches and in the press along with the promotion of the Russian language and the concept of the rapprochement of nations. Gone, however, were the sovnarkhozy and official statements regarding the fusion of the nationalities into a single Soviet nation. Instead, the Brezhnev leadership emphasized trust in cadres - leaving many Party officials in office for long tenures - and the insistence that the 
Soviet people be given a proper internationalist upbringing. After 1971 and the formal introduction of Developed Socialism, these concepts were maintained by the Brezhnev leadership but were strengthened in the name of building communism.

Through most of the 1960s, the Brezhnev leadership in Moscow and the various republic leaders tended to emphasize different aspects of nationality relations in their writings and in their speeches. During this time, all-Union officials in Moscow highlighted the friendship of peoples, the rapprochement of nations, the coming of the Soviet man, and the promotion of the Russian language as a means for inter-nationality communication within the USSR. Republic leaders, on the other hand, placed greater emphasis on the friendship of peoples and on the success of Leninist nationality policies, with less mention of the Soviet man and of the Russian language as a means of inter-nationality communication.

In his speech commemorating the anniversary of the October Revolution in November 1964, Brezhnev proclaimed "Now all the nations and peoples of our country live as a single, fraternal family. Friendship of peoples has entered into the flesh and blood of our public life. Russians, Ukrainians, Belorussians, Uzbeks, Kazakhs, Georgians, Azerbaijanis, Lithuanians, Moldavians, Latvians, Kirgiz, Tajiks, Armenians, Turkmenians, Estonians - all the peoples of our motherland - see one another as comrades and comrades-in-arms, help one another, work together, and participate together in the struggle to build communism. Such is the majestic outcome of the Leninist national policy."2 Later, Brezhnev announced "A new man is being raised in our country - a man of noble ideals and the lofty moral principles expressed in the moral code of the builders of communism. The concept of 'Soviet man' is synonymous with courage and staunchness, heroism in labor and arms, and lofty consciousness of social duty." Thus, Brezhnev's emphasis early in his tenure was the friendship of peoples and the coming of 
the new Soviet man, concepts that had also been important during the Khrushchev years. Other Party officials and theorists, however, focused on the Russians as the first among equals in the Soviet Union and on the issue of the Russian language. For example, Nikolai Podgorny stated to an Azerbaijani audience in 1965 that "With the help of the brother peoples, first and foremost the Russian people, the working people of Azerbaijan have traversed the equivalent of a centurieslong path in a brief historical period. From a backward outpost of tsarist Russia, Azerbaijan has been transformed into a highly developed socialist republic."3

Perhaps the most comprehensive statement outlining Moscow's stance on the nationality issue in the early Brezhnev period is an editorial in Kommunist entitled "Friendship of the Peoples who are Building Communism" published in November 1965. The primary focus in this article is the friendship of peoples. In this editorial, it is stated that "The economic basis of the friendship of peoples of the USSR is the public ownership of the means of production, the socialist system of economy." Through mutual assistance, it is argued, "the peoples of our country have joined firmly in a single close family and have become full-fledged masters of their lives, of their destinies." Additionally, the editorial states "The political basis of the friendship of the peoples of the USSR is the Soviet state system, our Soviet democracy." By guaranteeing the sovereignty of the Union republics, the equality of all Soviet peoples is ensured. Moreover, Marxism-Leninism unites the Soviet peoples "ideologically in the struggle for achievement of the common communist ideal, it inculcates a spirit of loyalty to proletarian internationalism..." The editorial then uses the example of the Great Patriotic War to demonstrate the "true friendship of the peoples of the Soviet Union" and their unbreakable bonds in the face of the Nazi aggressors. Next, the editorial states "Today, at the new stage of the development of national relations in the USSR that large-scale communist construction represents an increasing 
rapprochement of nations is in progress, prepared by the flowering of their material and spiritual forces under socialism and based on the stable and unbreakable friendship of the Soviet people, on the principles of proletarian internationalism." Due to the ongoing rapprochement of nations, the editorial states, greater social, ideological and economic unity is developing within the Soviet Union. As will be discussed later in this chapter, the latter statement in the editorial anticipates one of the primary components of Developed Socialism.

The Kommunist editorial discussed above did not mention the language issue as a component of the nationality question, but another article in Kommunist which appeared in September 1965 analyzed the language issue thoroughly. This article, entitled "The Development and Mutual Enrichment of the Languages of the USSR" ${ }^{35}$ written by Iu. Desheriyev, M. Kammari, and M. Melikyan, states that "in the process of the full-scale construction of communism, the task arises in all its urgency of studying the state of the languages of the Soviet peoples and the prospects for their further development, interaction and mutual enrichment." The focus in this article, then, is what happens to languages in the Soviet Union during the process of the rapprochement of nations. Desheriyev et.al. argue that Karl Kautsky was wrong in predicting that one nation will assimilate all other nations and that one language will assimilate all other languages as well. Instead, they argue, Lenin was correct in that he "always upheld the Marxist idea of the future merging of nations in a higher, internationalist unity of mankind. But he did not raise the problems of the merging of national languages. The established literary languages of nations show no tendency to merge into a single language." The strengthening friendship of peoples, according to Desheriyev et.al., will naturally lead to the development and mutual enrichment of the languages within the USSR. Forced assimilation of language, they argue, is simply racist and is a policy followed by the 
imperialist powers in Africa and Asia. Yet despite denouncing a forced assimilation of language as a form of imperialist oppression, Desheriyev et.al. argue that in the Soviet Union "The processes of the mutual enrichment of the languages of the USSR are revealed most clearly in the development of their lexical composition through common words formed chiefly on the basis of internationalization of the vocabulary and word stock of the Russian language...” Just as the Russian language enriches the non-Russian languages through borrowed vocabulary, so do the non-Russian languages enrich the Russian language. This is mutual linguistic enrichment made possible by the process of the rapprochement of nations, they argue. But Desheriyev et. al. assert that even through the Russian and non-Russian languages enrich each other, it is clear that only the Russian language is suitable for inter-national communication in the Soviet Union. They outline four characteristics of the Russian language that make it the most suitable for international communication: first, "Russian is the native tongue of more than half the population of the USSR"; second, "the Ukrainians and Belorussians...usually know the Russian language, which is closely akin to Ukrainian and Belorussian"; third, "a large part of the non-Russian population of our country knew Russian even before the October Revolution.”; fourth, "the outstanding vanguard role of the Russian people in overthrowing tsarism and casting off the yoke of tsarist and 'homegrown' oppressors and the fraternal assistance of the Russian people...greatly helped the Russian language to fulfill the functions of a language of internationality communication..."; and finally, "historically established traditions, the historical role played by Russian culture and science in the development of the cultures of the peoples of the USSR were of great importance for promoting Russian as the language of inter-nationality communication." Yet despite all of these attributes, Desheriyev et.al. are careful to note that the 
Russian language does not enjoy a privileged place within the Soviet Union. It is on an equal footing with the other languages of the USSR.

While the focus of the rhetoric coming from Moscow during the early years of the Brezhnev era was placed on the rapprochement of nations, the friendship of peoples, and on promoting the Russian language as a means of inter-national communication, the rhetoric from the Union republics often had a slightly different emphasis. A good example of this different focus is the stenographic report of the $14^{\text {th }}$ Kirgiz Party Congress held in March 1966. In his speech delivering the Kirgiz Central Committee report to the Congress, Kirgiz First Secretary T.U. Usubaliev heralded the CPSU's Leninist nationalities policy and the friendship of the peoples of the USSR. Usubaliev stated "The victory of socialism in Kirgizia is the brilliant triumph of the Marxist-Leninist idea, of the Leninist nationality policy of the Communist Party and the Soviet government. It is an example of the great, life-affirming forces of Soviet social and state construction and the brotherly friendship of the Soviet peoples. Kirgizia is now one of the bright lighthouses of the East, calling the peoples of Asia and Africa to the great revolutionary achievements." Usubaliev also stated to the Congress that "We must continue to spare no effort to strengthen the unshakable brotherly friendship of peoples, and strongly resist even the slightest manifestation of national narrow-mindedness, the remnants of nationalism, and lead the struggle against anything that could weaken our unity."7 At no point in Usubaliev's report to the $14^{\text {th }}$ Kirgiz Party Congress did he refer to the Russian people or to the Russian language. His speech is truly "internationalist" in nature with special emphasis on the friendship of peoples and the successes of the Leninist nationality policy. As will be discussed later in this chapter, Usubaliev's speeches will take on a more pro-Russian tone in the 1970s as a result of Developed Socialism. 
Other speeches at the $14^{\text {th }}$ Kirgiz Party Congress echo Usubaliev's internationalist sentiments. In his speech delivering the report of the Credentials Commission, A.V. Samosudov praised Leninist nationality policy and "proletarian internationalism" as its "unshakable basis". He added "Reflection of the triumph of this policy is the composition of the delegates to the $14^{\text {th }}$ Congress in which 26 nationalities are represented. The multinational composition of the Congress reflects the party's concern for the raising and care of cadres from all nationalities. At this Congress there are 378 Kirgiz, or 46.2\%; 277 Russians - 33.9\%; 66 Ukrainians - 8.1\%; 39 Uzbeks $-4.8 \%$; 10 Kazakhs $-1.3 \% .^{\text {" } 8}$ These statistics make the $14^{\text {th }}$ Kirgiz Party Congress's decidedly internationalist tone all the more striking - there were 378 Kirgiz delegates and 343 Slavic delegates (Russians and Ukrainians combined). Indeed, the Kirgiz themselves comprised less than half of the delegates to the Congress. And again, the internationalist tone of this Congress must be viewed in contrast to the internationalist, yet subtly pro-Russian, rhetoric coming from Moscow at the time.

While Usubaliev and other speakers at the $14^{\text {th }}$ Kirgiz Party Congress did not praise the Russian people nor speak of the need to educate the Kirgiz in the Russian language, some speakers at the $14^{\text {th }}$ Kirgiz Party Congress did. T. Kulatov, the Chair of the Presidium of the Kirgiz Supreme Soviet, stated to the Congress that "The main aspect of the successes of our republic is the constant paternal care of the Communist Party and Soviet government for the development and flourishing of Soviet Kirgizstan in the great multinational family of Soviet peoples. Our successes are the triumph of Leninist nationality policy, the resulting solidarity and aid of the Soviet Union, and the result of the brotherly and selfless assistance of the great Russian people and all of the peoples of the Soviet Union." ${ }^{9}$ In a similar vein, S. Tabyshchaliev, the rector at Kirgiz State University, announced that a "group of Kirgiz youth are specializing in 
teaching the Russian language and Russian literature. Many pupils are taught in the Russian language." 10

Thus a mixed message emerged from the $14^{\text {th }}$ Kirgiz Party Congress. Party First Secretary Usubaliev avoided the Russian language issue and refrained from praising the Russian people in his report, while other delegates at the congress did address these issues. As will become clear, this was a common occurrence at certain republic party congresses, most notably in the Central Asian republics. Such mixed messages are evidence that during the Brezhnev period, republic party first secretaries had carefully to counterbalance the centralizing tendencies of Moscow and the developing national interests of their home republics. This balancing act grew more pronounced as authorities in Moscow placed greater emphasis on the principles of Developed Socialism through the 1970s.

\section{Developed Socialism as Theory}

In some respects, the $24^{\text {th }}$ CPSU Congress, held in 1971 , is to Brezhnev what the $20^{\text {th }}$ CPSU Congress was to Khrushchev in that it signaled an important shift in Party policy, albeit without the fanfare of the $20^{\text {th }}$ Congress. It is at the $24^{\text {th }}$ CPSU Congress that Brezhnev officially unveiled his theory of Developed Socialism, the theory that will guide the Soviet Union throughout the remainder of Brezhnev's tenure and will dominate official discourse until the Gorbachev era.

In his speech delivering the Central Committee's report to the $24^{\text {th }}$ Congress, Brezhnev stated that "In our country, it will be recalled, socialism triumphed back in the latter half of the thirties. This was followed by more than three decades of the Soviet people's heroic labor and struggle. Our economy of that time and our present-day economy are based on the same type of 
relations of production, on the same economic laws, the laws of socialism." Brezhnev then explained that the Soviet economy and Soviet society of the early 1970s had reached even higher stages of development than those of the previous three decades. Therefore, Brezhnev reasoned, "The developed socialist society to which Lenin referred in 1918 as to the future of our country has been built by the selfless labor of the Soviet people. This has enabled us to tackle in practice the great task set by the Party Program...that of building the material and technical basis of communism."

In essence, for Brezhnev, Developed Socialism meant that the Soviet Union had completed the task of building socialism and now could prepare for building communism. Much of Brezhnev's report to the $24^{\text {th }}$ Congress, then, was devoted to discussing the economic implications of this transition period, with emphasis placed on modernizing the Soviet economy, enhancing agricultural output, and on improving the production of consumer goods. Yet, as Brezhnev explained, Developed Socialism has implications that reach deeper into Soviet society than economic development and modernization. Developed Socialism also has very important social, class, and nationality ramifications. Brezhnev emphasized that "The Party's policy is directed towards helping to bring the working class, the collective-farm peasantry, and the intelligentsia closer together, and gradually erasing the essential distinctions between town and countryside and between mental and physical labor. This is one of the key sectors in the building of a classless communist society." ${ }^{\prime 2}$ Fusing the working class, peasantry, and intelligentsia is of course not a new concept in Soviet ideology, but Developed Socialism placed an even greater emphasis on the theme of fusion than previous Soviet discourse. Not only did Brezhnev stress the importance of class fusion, but he also placed great emphasis on the drawing together of nationalities in the Soviet Union as a vital process for building the basis of a communist society. 
Brezhnev declared that "All the nations and nationalities of our country, above all, the great Russian people, played their role in the formation, consolidation and development of this mighty union of equal nations that have taken the road to socialism. The revolutionary energy, dedication, diligence, and profound internationalism of the Russian people have quite legitimately won them the sincere respect of all the other peoples of our socialist motherland." Brezhnev continued by announcing that "Further progress along the road of the all-round development of each of the fraternal Soviet republics, along the road of the further gradual drawing together of the nations and nationalities of our country, has been made during the past few years under the Party's leadership. This drawing together is taking place under conditions in which the closest attention is given to national features and the development of socialist national cultures." Moreover, Brezhnev stated that "The Party shall continue to strengthen the Union of Soviet Socialist Republics, consistently pursuing the Leninist line of promoting the florescence of the socialist nations and securing their gradual drawing together." Finally, Brezhnev declared that "A new historical community of people, the Soviet people, took shape in our country during the years of socialist construction... Our people are welded together by a common MarxistLeninist ideology and the lofty aims of building communism. The multinational Soviet people demonstrate this monolithic unity by their labor and by their unanimous approval of the Communist Party’s policy."13

The essential theme of Developed Socialism, then, is that of consolidation; the drawing together of the workers, peasants, and intelligentsia; the ending of the differences between town and country, and, above all, the drawing together of the nations and nationalities into a "new historical community of people, the Soviet people." As will be demonstrated later in this chapter, the theory of Developed Socialism really called for a further consolidation of the Soviet 
Empire through its emphasis on "monolithic unity", the economic consolidation of the various Union Republics, the far-more prevalent statements in the Soviet press praising the Russian people and promoting the use of Russian as a means for inter-nationality communication, and finally, the erosion of Union Republic sovereignty in the new 1977 USSR Constitution and the 1978 Union Republic constitutions. Developed Socialism therefore represents the Brezhnev regime's primary strategy of approaching the nationality question - that of tightening the bonds between the Soviet center and periphery.

Despite the importance of Developed Socialism for understanding the Brezhnev regime's approach to the nationality question and its apparent call for further consolidating the Soviet Empire at the expense of Union Republic sovereignty, the concept remains relatively obscure in the historiography. Indeed, George Breslauer ignores Developed Socialism in his study of Khrushchev and Brezhnev. Nor does Ronald Suny mention Developed Socialism in The Soviet Experiment. Alfred B. Evans, Jr. has written the most extensive studies on Developed Socialism in the form of two articles published in 1977 and 1986. For Evans, Developed Socialism represents a retreat by the Brezhnev regime from Khrushchev's ambitious declaration that the USSR will have begun building communism by 1980 as well as a new emphasis on social unity. Evans argues that "Brezhnev ignored Khrushchev's promise of the achievement of communism in the 1980s. But the caution of Soviet leaders left a vacuum of ideological guidance. The leaders faced a dilemma." To fill this ideological vacuum, Evans explains that Developed Socialism meant "a new periodization of the Soviet experience, and of post-capitalist progress." Whereas Marx envisioned two periods of post-capitalist progress, Lenin outlined three, while Brezhnev's theory of Developed Socialism identified four periods: Building Socialism (19171936), a Socialist Society after 1936, the period of Developed Socialism beginning in the early 
1960s, and then eventually the building of Communism. ${ }^{14}$ Thus, Evans argues that Developed Socialism, in part, was a clever way for the Brezhnev leadership conveniently to ignore Khrushchev's earlier ambitious promise while still adhering to the ideological goal of building communism.

But more than simply delaying Khrushchev's promise of a communist society, Evans argues that Developed Socialism also called for greater social unity and cohesion. He writes, "Perhaps the principal criterion of the developed stage of socialist social relations is a high level of social unity...Homogeneity will be manifested by the communist society of the future, but unity is an accomplishment appreciated in the present stage. According to the Soviet argument of many years, the basis of social unity is socialism, eliminating exploitation and class antagonisms. In addition, a basic assumption of Soviet social theory and policy is that the economic modernization of diverse areas of society will result in growing cultural integration. Still another familiar means of national and ideological unification in the USSR, to which writers on developed socialism frequently refer, is the use of educational institutions as socializing agencies." Evans adds that "When authors define a high level of social unity as a criterion of developed socialism, they appear to place a subtle stress on moral and political unity, the sharing of common values, rather than the elimination of differences between social strata." ${ }^{15}$ Evans is correct in his overall evaluation of Developed Socialism as an ideological retreat from Khrushchev's grand ambitions and as a call for greater unity within the Soviet Union. However, Evans, like other authors on the theory of Developed Socialism, ignores the impact Developed Socialism had on Soviet nationality policy in the 1970s. While most Soviet theorists and Party officials emphasized the economic ramifications of Developed Socialism, some carefully and more subtly applied the theory to the nationality question. What follows is a review of Soviet 
literature on Developed Socialism from the 1970s which will demonstrate that Developed Socialism formed an integral part of the Brezhnev leadership's approach to the nationality question. Indeed, Developed Socialism meant the further consolidation of the Soviet Empire, with the new USSR Constitution and the new Union Republic constitutions adopted in 19771978 as the theory's crowning achievement.

The most comprehensive and substantial theoretical discussions of Developed Socialism appeared in Kommunist, the Party's theoretical journal, in 1972-1974. Almost every issue of Kommunist during this three year span contained articles relating to Developed Socialism, many of them written by prominent Party members such as Aleksei Kosygin or by the secretaries of the Union Republic parties. Still other articles were written by economists or linguists. These articles explain seven basic components of Developed Socialism: the Soviet Union as a "single economic complex", the cultural unity of the Soviet Union due to the benevolent assistance of the Russians, the flowering of nations and nationalities and their ongoing rapprochement [sblizhenie] due to the success of the Party's Leninist nationality policy, the development of the Soviet people as a new historic community of people, the importance of the Russian language as both a means for inter-national communication within the USSR and as a vital carrier of culture and high learning to the non-Russian peoples, the building of a communist society primarily through the issues listed above and through continued economic modernization, and lastly a strong emphasis on the internationalist upbringing of the people. A key overriding principle in all of these seven facets of Developed Socialism discussed by intellectuals and prominent Party officials is that of increasing the unity of the Soviet Union, which is a subtle euphemism for consolidating the Soviet Empire. Not all authors address all seven aspects of Developed Socialism, and I will not discuss all of them in detail. Rather, some aspects are emphasized over 
others. As will become clear, though, Developed Socialism made the Soviet Union more imperialist, in some respects more imperialist than the Stalin years. Although never concretely stated as such, Developed Socialism became the Brezhnev leadership's primary strategy for solving the nationality question. And, as will be discussed later, while the principles of Developed Socialism called for the further consolidation of the Soviet Empire, certain other existential factors acted to impede the process of consolidating the empire and actually contributed to a developing decolonization process, namely Brezhnev's own trust in cadres policy regarding Party personnel, and foreign policy pressures that came to the fore in the 1970s. Illustrative of the economic unity facet of Developed Socialism is an article in Kommunist by Antanas Snechkus, the First Secretary of the Lithuanian Communist Party. In his article "Velikaia Sila Sotsialisticheskogo Internatsionalizma", Snechkus states that "The economic development of Lithuania is accompanied by a comprehensive expansion and deepening of mutual connections with the fraternal republics... The Russian Federation, Ukraine, Belorussia, and Azerbaijan supply us with metal and steel pipes, oil and raw materials for the chemical industry, equipment for power stations, automobiles, tractors, and combines." Moreover, he writes that Lithuania "contributes to the economy of the entire country...Increased economic cooperation promotes the unification of all of the soviet republics and economic regions of the country into a single economic organism. On the basis of economic connections lie the rational distribution of productive forces, the development of specialization and cooperation in production, and the full use of the experiences of the assistance of the other fraternal peoples." As a result, for Snechkus “The development of comprehensive economic ties between the republics is an objective law, the most important objective factor contributing to the consolidation of the friendship of peoples, to their rapprochement." ${ }^{16}$ Finally, it should be noted 
that Snechkus singles out the Russian people as "the culture and art of the great Russian people" played a vital role in developing the socialist culture and art of Lithuania. The Russians also provide "great assistance to the Lithuanian people in the construction of a communist society."

Developed Socialism's focus on unity and the benefits of this unity for the nationalities of the USSR is perhaps best illustrated in Petr Masherov's article "O Nekotorykh Chertakh i Osobennostiakh Natsional'nykh Otnoshenii v Usloviiakh Razvitogo Sotsializma” [Some Features and Peculiarities of National Relations in the Conditions of Developed Socialism] ${ }^{17}$. Masherov was the First Secretary of the Byelorussian Communist Party. He outlines the main principles of what he calls the scientific program for the Party's nationality policy. These main principles include "the self-determination and complete equality of nations; the unity of the workers and all laborers of the various nationalities in the struggle for democracy and socialism; the close voluntary political, military, and economic union of peoples embarking on the socialist path of development; the guarantee of the factual equality of nations through the development of the joint forces of their economies and cultures on the basis of fraternal mutual-assistance and comprehensive cooperation; the flowering and rapprochement of socialist nations." Moreover, Masherov explains that the factors inherent in a mature socialist society such as the Soviet Union include "the transformation of the all-union economy, reaching a high level of development, to an internally coherent, well-coordinated inter-connected national economic complex which includes the national economy of all Soviet republics developing according to a single state plan in the interests of the entire country and of each republic individually." For Masherov, then, Developed Socialism means, in part, an ever-rising level of unity among the peoples and classes of the Soviet Union. 
In addition to rising unity, though, Masherov also extensively explains the meaning of the rapprochement of nations in a mature socialist society. Masherov claims that the process of the rapprochement of nations goes hand in hand with ever-increasing levels of the internationalization of the populace. According to Masherov, "Contemporary Soviet reality convincingly demonstrates that in the conditions of developed socialism, both trends - to the flowering and rapprochement of nations - are given full scope with the trend toward rapprochement acquiring the leading role, resulting in an increased role for the internationalization of all areas of national development." Additionally, Masherov writes, “The objective of this development is the dialectic that the strengthening of the international becomes an indispensable condition for the further flowering of the national, and the growing rapprochement, cooperation and mutual enrichment of nations leads to new and higher economic, political, and spiritual development of each nation." Thus, as the peoples of the USSR grow more internationalist in their worldview, this process will inevitably lead to the further development and enrichment of the cultures of each nation. In other words, Masherov is arguing that nations bloom only in the soil of internationalism.

If Masherov's argument seems contradictory, this is no accident. In the rhetoric of Developed Socialism, internationalism can be read as a code word for russification, primarily linguistic and cultural russification. This is why Developed Socialism is an inherently imperialist policy and why it will breed resistance in the 1970s. Masherov and other officials writing on the merits of Developed Socialism were always very careful to avoid the term assimilation. Recall that in the Kommunist article on the language issue by Desheriyev, et.al. the authors denounced assimilationist language policies as racist, a tool used only by bourgeois imperialists. Leninist theory also pointedly condemned forced assimilation as a bourgeois 
imperialist practice. So while Developed Socialism called for assimilation, in the Soviet mind such assimilation was really internationalist - the nations of the Soviet Union were voluntarily learning the Russian language and were voluntarily undergoing the process of rapprochement. Admittedly, this is an issue of semantics, but western scholars have agreed that wording reflected official attitudes and behind-the-scenes political disputes. Assimilationist policies are bourgeois imperialist. Internationalism is a natural product of the building of socialism and is voluntary and inherently democratic. That the two both lead to the same general result - some form of cultural or linguistic imperialism - did not matter to Soviet theorists.

In the discussions of Developed Socialism, the continued consolidation of the Soviet Union into a single economic complex was couched in terms of economic development deemed beneficial to the individual republics. For example, N. Baibakov, the Chair of Gosplan, wrote in 1972 that "Our multinational state - the Union of Soviet Socialist Republics - is developing as a united whole. Its achievements are the result of uniting the forces of all peoples, big and small." More specifically, Baibakov notes that "The social-economic changes undertaken in our country under the leadership of the Communist Party have led to the emergence of a fundamentally new historical community of people - the Soviet people. The main economic prerequisite for its formation has been the establishment of the public ownership of the means of production. The creation and development of the socialist method of production is the most solid foundation of the relations of fraternal friendship, the mutual-assistance and cooperation between the classes and social groups, of all nations and nationalities, the constituent parts of the Soviet people, has united the economy of all republics into a single national-economic complex." Baibakov, then, championed the results of the consolidation of the USSR into a single economic unit. 
However, Baibakov is careful to point out that this does not mean that the individual economies and concerns of the Union Republics are being ignored. On the contrary, Baibakov asserts that the further consolidation of the USSR into a single economic complex is very beneficial to the republics as it allows them to specialize in particular economic activities. He notes that "The half-century experience of the USSR convincingly demonstrated the advantages of the centrally-planned guidance of the economy in guaranteeing the high rate of development of all of the republics and regions of the country, the full use of the objective possibilities of the socialist economic system, the increased effectiveness of production, and the growth of the material well-being and of the cultures of the people." In addition, "the national economy of the country represents the unity of the economies of all of the republics and regions, characterized by a certain territorial division of social labor. The preferential development of individual sectors and industries in different republics and economic regions creates the conditions for the territorial concentration of production and for more effective use of the resources of each republic and region." Because of this, Baibakov explains, "each republic has the ability routinely to specialize in those sectors and industries which for it are more effective and at the same time necessary for the complex development of the national economy of the country as a whole. Such economic specialization ensures the rational combination of the republic's economic interests with those of the national economy of the USSR and it allows us to achieve a high rate of development of social production."

As an example of the benefits of the republics' ability to specialize in certain economic sectors, Baibakov cites Uzbekistan. He argues that "In the republics, there are created industrial, technological and economic connections based on industrial specialization. Thus, Uzbekistan became a major producer of farm machinery for cotton production; here are the construction 
bureaus and factories engaged in the design and building of machines for all domestic cotton production. The Uzbek SSR not only grows cotton, it also processes it. The needs of the textile industry led to the development of textile machine-building in Uzbekistan." The economic specialization of the republics, made possible by the further development of the USSR as a single economic complex, results in the further economic development and diversification in the individual republics, according to Baibakov. The creation of the national-economic complex also enabled the republics to assist each other financially - such "pooling of resources" as Baibakov refers to it, allowed for places such as the Central Asian republics to develop more quickly than they otherwise would have. ${ }^{18}$

Aleksei Kosygin echoed Baibakov's analysis of the benefits of the USSR as a single economic complex. Kosygin wrote that "The developed socialist society in our country has been built as a result of the selfless labor of all the nations and nationalities that comprise the Soviet Union. Through the creation of a single multinational socialist state, the assertion of socialist ownership of property, and the liquidation of the exploiting classes in the USSR generally and in each republic individually, guarantees the higher pace of economic development, implements broad social transformations and has achieved a high standard of living for the people and the flowering of culture.” More so than Baibakov, however, Kosygin linked the economic development of the USSR as a whole to the nationality issue. For example, Kosygin argued that "the construction of the material-technical base of communism contributes to the further strengthening and improvement of the voluntary union of socialist nations, their flowering and their rapprochement.” Moreover, according to Kosygin, “The Soviet Union's progress in economic, scientific and cultural development, its defensive might, and its international authority are all the result of the Leninist nationality policy of the Communist Party, expressing the native 
interests of all peoples, rallying the fraternal union of republics into a single multinational socialist state."19 Just as internationalism is used as a code word for assimilation and is presented as beneficial to the nations of the USSR, Kosygin and Baibakov also couch the economic imperialism inherent in Developed Socialism as mutually beneficial for the nations of the Soviet Union.

In 1973, Iunus Desherievich Desheriev, a Chechen linguist who belonged to the Chechen Academy of Sciences, published 'Razvitie Natsional'nykh Iazykov i Iazyka Mezhnatsional'nogo Obshcheniia" [The Development of National Languages and the Language of International Communication] in Kommunist. Like the earlier work he co-authored with M. Kammari and M. Melikyan in 1965, in this article Desheriev continues the argument that the Russian language naturally serves as a language of inter-national communication and as a vehicle for culture and knowledge to the non-Russian peoples. He begins his analysis by pointing out the "evils" of assimilationist language policies pursued by imperialist powers. He writes, "The imperialist policy of the suppression of the cultures and languages of national minorities, of the oppressed peoples, of the violent assimilation of the small nations by large nations were opposed by the idea of the comprehensive development and brotherly cooperation of the great and small nations and nationalities and the mutual enrichment of their cultures and languages." Such policies, Desheriev notes, resulted in "A dismissive attitude to national development and identity of peoples received practical expression in the policy of 'freezing' the culture and languages of oppressed nations and ethnographic groups in colonized and in free countries carried out by the imperialist powers." Assimilationist policies still permeate the bourgeois parts of the globe, according to Desheriev, as "The modern capitalist world is characterized by an increasing assimilationist policy in the area of solving the language problem. In the USA, for example, 
many millions of Italians, Germans, and representatives of other nationalities do not have their own state autonomy within which to develop their national cultures and language. As a result of strong political and economic pressure from the ruling classes, they undergo intense assimilation." Thus, the Soviet Union is superior as its national minorities have varying forms of autonomy and can freely use their native languages, whereas the Italians of northern West Virginia or in Brooklyn are oppressed as they lack national autonomy within the United States. Desheriev, then, is making the same argument as the other authors discussed above, especially Masherov, that assimilation is imperialist, internationalism is not.

Desheriev's argument is more clearly stated when he writes, "In the conditions of fraternal friendship and of the mutual trust of the peoples, national languages are developing on the basis of equality and mutual enrichment. The voluntary study of the Russian language - the language of international communications and cooperation for all the peoples of the Soviet Union - by the representatives of each nation and nationality of our country promotes the mutual exchange of experience, their access to the cultural achievements of all of the other peoples of the USSR and to world culture." Because the non-Russians voluntarily learn the Russian language, the languages and cultures of the peoples of the Soviet Union are mutually enriched. Desheriev and all other authors on this subject are silent as to whether Russians learning nonRussian languages achieve the same degree of mutual enrichment. In essence, language is one of the keys to the further internationalization of the peoples of the USSR and of the continued rapprochement of nations. Desheriev explains that "The process of the interaction and mutual enrichment of languages complementing the main source of the development of literary language is its internal resources and promotes the further development of the languages of the USSR...the successful solution of one of the important sociological problems is mastery by the 
non-Russian population of our country of the Russian language, the language of international communication. All of this is in the interests of the comprehensive development and rapprochement of nations, nationalities and the objectives of the mutual enrichment of languages" (emphasis added). To be sure, Desheriev does point out that the Russian language itself has been enriched by the non-Russian languages mainly through borrowing certain terms from various languages. But the overriding message is that Russian is a progressive language in the Soviet Union, the natural choice for a lingua franca. Moreover, Desheriev argues that further development of Russian as the language of inter-national communication within the Soviet Union actually will promote the further rapprochement of nations. He explains, "In the process of creating the conditions for the free and unhindered development of the national languages in our country, there has been taken into account the need to improve the social role of the Russian language as a general language for international communication among the peoples of the USSR. Expansion of its role in the development and rapprochement of the nations and nationalities and their cultures is due to social factors and to the objective laws of socialist and communist construction.” Linguistic unity, along with economic and cultural unity, are key components of Developed Socialism. Tightening the bonds between Moscow and the periphery, then, is the chief aim of Developed Socialism and thus forms the basis of the Brezhnev leadership's nationality policy.

As has probably become apparent, many of the most staunch proponents and theorists of Developed Socialism were non-Russians. Snechkus was Lithuanian, Masherov was Byelorussian, Desheriev was a Chechen. Note that the three men listed above are either from Western Soviet Republics or from an ASSR within the Russian Republic. This fact is evidence that regional diversity existed in terms of nationality policy. The leaders of the Western 
Republics were devoted followers of Brezhnev and thus of Developed Socialism and its concomitant tightening of the Soviet Empire. To not faithfully support the Party line in the Western Republics could mean removal from office. Indeed, in 1972, Brezhnev removed Petro Shelest from his position as First Secretary in Ukraine ostensibly for Shelest's alleged tolerance of manifestations of Ukrainian nationalism. Shelest's replacement, Volodymyr Shcherbitskii, was a more faithful colleague for Brezhnev and more faithfully endorsed the precepts of Developed Socialism. On the other hand, in Transcaucasia and Central Asia, resistance to the further consolidation of the Soviet Empire became evident in the 1970s. It is resistance in these areas that forced the Brezhnev leadership to back away from their most ambitious efforts to consolidate the empire in the late 1970s as will be discussed later in the next chapter. Thus, while Developed Socialism called for greater unity and uniformity within the Soviet Union, not all officials will comply. Such noncompliance was evidence of a budding decolonization process in some parts of the Soviet Union during the 1970s and ultimately led to the problems Mikhail Gorbachev faced in the 1980s. 


\section{CHAPTER FOUR}

\section{REPUBLIC LEADERS AND DEVELOPED SOCIALISM}

As Chapter three indicated, Developed Socialism formed the theoretical basis of Brezhnev's nationality policy. The tenets of Developed Socialism encouraged the further consolidation of the Soviet Empire through their emphasis on the continued rapprochement of nations within the Soviet Union, the development of the USSR into a single economic complex in which each republic specialized in certain economic sectors, the promotion of Russian as the logical language for inter-national communication within the Soviet Union, the continued "internationalization" of the workers' worldview, and finally the formation of a new Soviet national identity which exhibited decidedly Russian attributes. It must also be remembered, however, that the centralizing tendencies of Developed Socialism were rooted in Leninist ideology, as indicated in Chapter Two. Thus Brezhnev served as an anti-imperialist imperialist. Moreover, it must be stressed that Developed Socialism continued the Leninist theme of nationality convergence as an evolutionary process. The rapprochement of nations was never intended to be fully accomplished overnight, rather it was a long process similar to the lengthy transition from socialism to communism. Thus, while Brezhnev-era rhetoric heralded the coming of the Soviet people, it was recognized that this new supra-national nationality had not yet fully formed but it will eventually through the rapprochement of nations and the internationalist upbringing of the working class.

Yet while Developed Socialism and Brezhnev's policies generally envisioned a further consolidation of the Soviet Empire at the expense of peripheral sovereignty, others of Brezhnev's policies acted to impede the process of empire consolidation and instead worked to enhance the 
decolonization process in certain areas of the Soviet Union. Brezhnev's trust in cadres policy, which he enacted upon assuming power in 1964 to gain the support of Party functionaries and to end the Party upheavals of the Khrushchev period, acted as a brake on the empire consolidation called for in the tenets of Developed Socialism. Because Brezhnev was reluctant to remove local Party leaders except in extreme circumstances, he contributed to the decolonization process as long-serving republic first secretaries were able to establish local power bases and, especially in Central Asia, they were tolerant of manifestations of local nationalism. Finally, the pressures of foreign policy furthered the existence of regional diversity in terms of nationality policy and forced Moscow to continue to take a softer line on Central Asia than on the western Soviet Union.

\section{Developed Socialism in Action}

Although Developed Socialism is key to understanding the Brezhnev leadership's approach to the nationality question, it is important to note that the policy was only applied incompletely. As has already been discussed and will be discussed further in this section, much attention to Developed Socialism was devoted in the speeches and writings of various officials and academics in Moscow and in the republics. But as will become clear in this section, not all republic authorities bought in to Developed Socialism entirely. And for the most part, those republic officials who did little more than pay lip-service to the precepts of Developed Socialism appear to have not faced any repercussions from Moscow, save for Petro Shelest in Ukraine. Rather it appears that as long as republic officials paid proper homage to Moscow and did not tolerate too much nationalism in their home republics, their tenure in office remained safe, due in large measure to Brezhnev's trust in cadres policy. Moreover, the incomplete acceptance of Developed Socialism among republic officials is further evidence of the continued existence of 
regional diversity in nationality policy - Shelest was removed in Ukraine, while Rashidov of Uzbekistan and Rasulov of Tajikistan were allowed to remain - and it is evidence that foreign policy concerns were at play. The Western republics were more tightly controlled as they formed the front line in the Cold War, especially after the Soviet invasion of Czechoslovakia in 1968, while the Central Asian republics were permitted more leeway, likely because this region (especially Uzbekistan and its capital Tashkent) was used as a model by the Soviet Union to demonstrate to the Muslim world the advancements attained by Soviet Muslims through Soviet communism. What follows, then, is a discussion of the acceptance of Developed Socialism in the republics drawn primarily from republic party congress reports and certain writings by republic officials. Not all fifteen republics are represented here, only select republics to serve as an example of the varying degree of the acceptance of Developed Socialism in the republics.

In his speech delivering the Central Committee's report to the $15^{\text {th }}$ Congress of the Kirgiz Communist Party in 1971, First Secretary T.U. Usubaliev devoted much attention to the friendship of peoples and the process of the rapprochement of nations in the Soviet Union. He noted "There are representatives of many nationalities among the republic's leading cadres. This is one of the bright examples of the triumph of the CPSU's Leninist nationality policy." Later, Usubaliev cited Brezhnev and declared "the building of communism in our multinational country assumes the consistent carrying out of the line for the comprehensive rapprochement of nations, the strengthening of their mutual cooperation and assistance. The path to this is in the further development of the economies and cultures of all of our republics, the improvement of mutual exchanges... and of course continuing the work on overcoming residual nationalism and chauvinism." Aside from the extensive discussion of the new Five Year Plan, which always dominated the proceedings at party congresses, Usubaliev at the $15^{\text {th }}$ Kirgiz Party Congress 
noted several times the continuing friendship of the Soviet peoples and the need to promote their further rapprochement. Yet in only one instance did Usubaliev mention the Russian people. He stated to the Congress that the successful development of Kirgizstan's politics, economy and culture is due to the "care of the CPSU Central Committee, the Party's Leninist nationality policy, and the unshakable friendship and mutual assistance of the Soviet peoples, first of all the assistance of the great Russian people."1 As Developed Socialism progressed as a theory and policy, praise for the Russians by the non-Russian peoples became commonplace. But as will be discussed below, not all republic officials will comply with this standard.

In striking contrast to the $15^{\text {th }}$ Kirgiz Party Congress, the $16^{\text {th }}$ Kirgiz Party Congress held in 1976 contains numerous praises for the Russian people and urgently highlights the need to improve the teaching of the Russian language in Kirgizstan. In his speech delivering the Central Committee's report to the $16^{\text {th }}$ Kirgiz Party Congress, Usubaliev declared, “The outstanding success in all areas of social-economic progress by the Kirgiz people is due to the Party's wise nationality policy, and to the generous fruits of the friendship and the selfless assistance from the fraternal peoples, primarily the great Russian people" (emphasis added). Usubaliev then repeated himself, "Allow me to also express, in the name of our congress, deep gratitude to the great Russian people, and to all of the fraternal peoples, for the constant selfless assistance to the Kirgiz people in economic and cultural development and in the raising of its well-being (Stormy Applause)."2 Thus in the space of a few passages in his speech, Usubaliev at the $16^{\text {th }}$ Kirgiz Party Congress praised the Russian people far more than he had five years earlier at the $15^{\text {th }}$ Kirgiz Party Congress.

In addition to heaping greater praise on the Russian people, Usubaliev went to great lengths at the $16^{\text {th }}$ Kirgiz Party Congress to highlight the need for improving the teaching of the 
Russian language in Kirgizstan. He stated to the congress, "I would like to emphasize the importance of such issues as improving the study of the Russian language in Kirgiz schools. The Russian language plays a tremendous role in the training and education of the younger generation in preparing qualified specialists and in international education... More than half of the scientific and technical literature and the best works of world literature are published in Russian." In this passage, Usubaliev was being pragmatic - in the Soviet Union of the 1970s, a thorough knowledge of the Russian language was necessary for higher education and for career advancement. But Usubaliev also waxed sycophantic when he referred to "the best works of world literature" as being in the Russian language. And Usubaliev went even further in his emphasis on the importance of the Russian language. He stated to the congress "It should be added that the study and knowledge of the Russian language, which is one of the richest contemporary languages, has become a vital necessity for all of the USSR's nations and nationalities. The Russian language has become the second native language of the Kirgiz people... and has become the most important means of international communication." In this statement, Usubaliev is signaling his compliance - and possibly his approval - of one of the key precepts of Developed Socialism - that of Russian as the means of inter-national communication within the USSR. He added that "The Kirgiz people study it [Russian] on their own, voluntarily. The massive desire to master the Russian language has become for us a truly new nationwide phenomenon that has had a huge impact on all aspects of life in our society. Knowledge of the Russian language opens wide possibilities for spiritual growth..."3 Thus, Usubaliev seemed to suggest that learning Russian had become a pop phenomenon in Kirgizstan, like rock and roll in the West. 
Yet despite all of the praise for the Russian language and the need to improve upon the teaching of Russian in Kirgizstan, Usubaliev and others at the $16^{\text {th }}$ Kirgiz Party Congress also note the need for developing the teaching of the Kirgiz language. Usubaliev stated that "Along with the further improvement in the study of the Russian language in the national schools, we must also develop the Kirgiz language, to improve its teaching, to make fuller use of the Russian language's beneficial effects on the enrichment of the Kirgiz language."4 In this statement, Usubaliev is again in technical compliance with the precepts of Developed Socialism. After all, Developed Socialism as a theory called for the mutual enrichment of cultures and languages as part of the ongoing process of the rapprochement of nations. It is also possible that Usubaliev is placating the more nationally-oriented members of his own party. As will be noted several times in this section, the republic first secretaries - especially in Central Asia - had to balance delicately the interests of their constituencies within their own republics with the mandates coming from Moscow. Unfortunately, with the materials available, it is impossible to discern with complete accuracy Usubaliev's motives in these statements regarding the Russian language.

K.G. Karakeev, the President of the Kirgiz Academy of Sciences, also noted the greatness of the Russian language at the $16^{\text {th }}$ Kirgiz Party Congress. Karakeev told the congress that "The Central Committee's report highlights the tremendous role of the Russian language in introducing the Kirgiz people to the riches of great Russian and world science and culture. Indeed, it is thanks to voluntary study that the Russian language has become the means of international communication among the peoples of the USSR." Like Usubaliev, then, Karakeev is complying with the precepts of Developed Socialism and its emphasis on Russian as a means of inter-national communication within the USSR. He is also careful to point out that learning Russian is voluntary. Recall that academics such as Iu. Desheriev emphasized that learning 
Russian must be voluntary, otherwise language policy would become assimilationist, which is a bourgeois imperialist policy. But while learning Russian is invaluable for the Kirgiz people, Karakeev also was quick to point out that "The study of the Russian language does not in any way harm the interests of the Kirgiz language, rather it promotes the further enrichment and development of the Kirgiz literary language"5 (emphasis added). As if to illustrate this point, Karakeev then recited to the congress part of a poem by Kirgiz poet Temirkul Umetaliev in the Kirgiz language.

S. Tabyshaliev, the rector at Kirgiz State University, echoed Usubaliev and Karakeev's sentiments regarding the Russian language and its teaching. He even noted that "the poor knowledge of Russian among the youth - especially in remote regions - is one of the reasons for the high drop-out rates of students. This is why we take special care to improve the teaching of Russian." But Tabyshaliev added, "If Russian is the means for international communication, then the Kirgiz language is the indispensable means of internal communication. Bilingualism does not divide nations; it brings them together."6

It is evident then that at the $16^{\text {th }}$ Kirgiz Party Congress, far more attention was paid to the study of the Russian language and praise of the Russian people than was seen at the $15^{\text {th }}$ Kirgiz Party Congress. This raises the question as to why so little was mentioned of these issues at the $15^{\text {th }}$ Kirgiz Party Congress yet so much was mentioned at the $16^{\text {th }}$ congress. Part of the reason why is that in 1971, Developed Socialism as an officially stated policy was still in its infancy. At that time, the rhetoric's primary focus still lie on the friendship of peoples, the mutual enrichment of cultures and languages, and the rapprochement of nations. By 1976, a renewed emphasis on uniformity and orthodoxy had entered Soviet officialdom. But another reason why there is such a shift at the Kirgiz party congresses is the issue of foreign policy. Usubaliev and 
other speakers at the $16^{\text {th }}$ Kirgiz Party Congress made references to continued problems with China. In his report, Usubaliev noted that "Religion causes great harm to the international solidarity of the workers. We must bear in mind that nationalist and religious remnants mutually feed off of each other...We must deeply and vividly show the triumph of Leninist nationality policy in concrete examples from our Soviet activities..." Soon after making this argument, Usubaliev then attacked the "anti-communist and anti-Soviet actions" of Mao and the Chinese. Moreover, A. Dvisheev, the First Secretary of the Issyk-kul Obkom, also attacked China, accusing it of being in league with Western imperialists. Dvisheev also noted that "Special Chinese radio broadcasts constantly produce anti-Soviet ideologically harmful propaganda in the Russian, Uighur and Kazakh languages." ${ }^{, 7}$ Likewise, Army General N.G. Liashchenko from the Central Asian Military District declared "The Maoists are our country's number one enemy." Therefore, the perceived threat and apparent provocations from China may help to explain why the $16^{\text {th }}$ Kirgiz Party Congress was so much more devoted to promoting the Russian language and the Leninist nationality policy than the $15^{\text {th }}$ congress five years earlier. The intent at the $16^{\text {th }}$ Kirgiz Party Congress may have been to tighten the bonds between Kirgizstan and Moscow to counteract any problems the Chinese may have been fomenting there.

The $17^{\text {th }}$ Kirgiz Party Congress held in 1981 was essentially a repeat of the $16^{\text {th }}$ Party Congress. Usubaliev again noted the importance of studying the Russian language and praised the Russian people for their "invaluable support". A slight difference, however, is that at the $17^{\text {th }}$ Party Congress, Usubaliev made more references to Developed Socialism and to Leonid Brezhnev as the author of nationality policy. He noted that "The period of developed socialism is characterized by the increasing role and importance of the Communist Party as the leading and guiding force of Soviet society."9 Moreover, Usubaliev stated "In reports and speeches, 
Comrade L.I. Brezhnev has deeply developed the important problem of the development of the multinational Soviet state and the CPSU's national policy. In these, he emphasized that in our country, the national question has completely been solved in the aspects that were inherited from the pre-revolutionary past. But national relations in a society of mature socialism is a reality that is constantly evolving, providing new challenges." Usubaliev's remarks at the $17^{\text {th }}$ Kirgiz Party Congress, then, continued the earlier theme of heralding the success of Leninist nationality policy and of paying homage to the principles of Developed Socialism.

It is apparent that at the $16^{\text {th }}$ and $17^{\text {th }}$ Kirgiz Party Congresses, Usubaliev was performing a delicate balancing act to placate both the imperialist policies coming from Moscow in the form of Developed Socialism and the more nationalist currents running through the Kirgiz Communist Party itself. Further evidence of Kirgiz officials working to balance Moscow's interests with Kirgiz nationalist interests is found in the speeches of Chingiz Aitmatov, the Chair of the Union of Cinematographers of the Kirgiz SSR. Aitmatov, who died in 2008, is regarded today as one of the great heroes of Kirgiz literature. His obituary in the New York Times noted that Aitmatov "gave a voice to the people of the remote Soviet republic of Kyrgiz[stan]."10 Tyntchtykbek Tchoroev, writing for Radio Free Europe/Radio Liberty, noted that Aitmatov's father, a prominent Kirgiz Party functionary, fell victim to Stalin's purges and that during the 1960s and 1970s, Aitmatov's writings defied “the ideology of mature socialism that promoted and glorified the merger of the USSR's smaller ethnic groups with the Russian people as their only path to a "bright future," albeit one in which their sense of national identity was lost."11 Aitmatov later served as Soviet ambassador to Luxembourg and became a close ally of Gorbachev in the 1980s. At the $16^{\text {th }}$ Kirgiz Party Congress, Aitmatov remarked "Of course, behind every people is its best traditions and artistic values accumulated during its previous history. Of course, every 
people brings from the depths of the ages its own native language... which sealed its knowledge of the world and the memories of generations." Aitmatov then declared "One of the monumental works of world literature is the immortal epic Manas, born of the genius of the people [naroda]. And we are proud of it and of our national heritage. We study it, we derive from it the treasures of the Kirgiz language.” Manas is an epic Kirgiz poem that historians believe is at least 1,000 years old. At over 500,000 lines, it is one of the longest poems in world literature and is regarded as a key storehouse of the Kirgiz language and culture. ${ }^{12}$ Aitmatov, then, was celebrating a key component of Kirgiz national identity.

But just as Usubaliev was quick to praise the Kirgiz language after calling for the need to study the Russian language, Aitmatov was quick to recognize the importance of the Soviet experience to his people. He stated "But nothing can compare with the experience we have gained of the new culture and knowledge mastered and multiplied during the years of Soviet power in the epoch of the October revolution. This is our greatest wealth, our highest intellectual climb in the entire history of all our compatriots, especially the Turkestanis including the Kirgiz people." Then, as if to placate further the interests of Moscow, Aitmatov spoke of "socialist internationalism" and the development of Soviet culture, concluding that "For us, this highly developed culture is, of course, the Russian Soviet culture, which appeared in the $20^{\text {th }}$ century leading the frontier of modern world civilization."13

Aitmatov continued his message at the $17^{\text {th }}$ Kirgiz Party Congress in 1981. At that congress, he again referred to Manas, calling it a "truly a great cultural event, a celebration of the Kirgiz poetic word - and yet another confirmation of the success of Leninist national policy. Its artistic heritage has been swept through the dark and stormy history by word of mouth from generation to generation. The Kirgiz people did not allow its poetic luminary to fade away on 
the winds of adversity." After his paean to Manas and the Kirgiz literary heritage, Aitmatov again was very careful to acknowledge the Soviet system's assistance to the Kirgiz: he remarked "Only in the Soviet era have we managed to affix the first elements [of Manas] to paper. Now the epic Manas is in the general treasury of the world's cultural monuments." He concluded by proclaiming "From a political standpoint, the epic Manas today represents a very important point against the hegemonic ambitions of Beijing."14

As is evident from the Kirgiz Party Congresses, a delicate balance had to be found by the local Kirgiz officials between Moscow's interests in the form of Developed Socialism and a nationalist current running through the Kirgiz Party. As such, it is difficult to discern whether Usubaliev was serious in his call to improve the teaching of the Russian language in Kirgizstan, his claim that studying Russian had become a "phenomenon" among the Kirgiz people, and in his praise for the Russian people and their role as the Kirgiz people's "elder brother." What is evident, however, is that the manifestations of Kirgiz nationalism demonstrated by Aitmatov's comments at the $16^{\text {th }}$ and $17^{\text {th }}$ Kirgiz Party Congresses would not have been allowed in the western republics such as in Ukraine. Due to a rising sense of Kirgiz national identity and to apparent provocative actions from China, Usubaliev had to make those comments to placate Moscow, yet Moscow could not take extreme measures to curb these displays of Kirgiz nationalism as it could result in provoking Kirgiz outrage. ${ }^{15}$

In neighboring Uzbekistan, longtime Party leader Sharaf Rashidov did not go to the extensive lengths that Usubaliev did in calling for the study of the Russian language or in praising the Russian people. Instead, Rashidov focused on other aspects of Developed Socialism, such as Uzbekistan's role in the single economic complex of the Soviet Union, the internationalist education of Uzbekistan's workers, and on the issues of the blossoming and 
rapprochement of nations in the Soviet Union. For example, in his speech delivering the Central Committee's report to the $19^{\text {th }}$ Uzbek Party Congress in 1976, Rashidov proclaimed in the opening portions of his report that "There has been a further blossoming [ rastsvet] and rapprochement of the socialist nations. The great friendship and brotherhood of peoples are the life-giving source of the mighty force of our state and are the foundation and key to the successful building of communism. In the USSR, there is firmly established a new historical community of people - the Soviet people, monolithically united behind its militant vanguard, the Communist Party." The only reference Rashidov made to the Russian language and to the Russian people came toward the end of his report to the $19^{\text {th }}$ Uzbek Party Congress. Here, Rashidov stated "The Russian language - the language of our elder brother, the great Russian people - functions as an important means of international communication and for the international education of the people." He added that "It is necessary to further develop and improve work on the education of the workers in the spirit of internationalism and the fraternal friendship of the peoples of the USSR." ${ }^{16}$ As with the speeches of Usubaliev in Kirgizstan, Rashidov in Uzbekistan is at least addressing the primary components of Developed Socialism the rapprochement of nations, the friendship of peoples, and the importance of the Russian language and of the Russians as the Uzbeks' “elder brother." But unlike Usubaliev, Rashidov does not go to great lengths to urge the study of Russian nor to attribute Uzbek successes to Russian assistance. Indeed, at the $19^{\text {th }}$ Uzbek Party Congress, it is the Chair of the Uzbek Writers' Union, K. Nugmanov, who goes to great lengths to praise the Russians. He stated to the congress "Without exaggeration, we can say that if we have achieved a rapid blossoming of all forms of spiritual culture, it is a direct result of the beneficial effects of good Russian literature and Russian art. If our novels and stories, verses and poems are read in many languages by the 
peoples of the world, it is due to the intermediary mission of the great and mighty Russian language..." He concluded his speech by stating "Allow me from this podium in the name of all of the workers of literature and art in Uzbekistan to express deep and sincere thanks to the great Russian language, to the advanced Russian culture, to our elder brother - the talented and generous Russian people." ${ }^{\prime 17}$ Nugmanov's speech to the $19^{\text {th }}$ Uzbek Party Congress, then, reads like a colonized people thanking their colonial masters for bringing to them the fruits of advanced civilization. And this is one of the primary messages of Developed Socialism and indeed of the entirety of Soviet nationality policy dating to the 1920s. Yet in practice, it appears that Nugmanov's task at the $19^{\text {th }}$ Uzbek Party Congress was simply to pay lip service to Moscow.

As noted above, Sharaf Rashidov only made passing reference to the Russian language and people in his report to the $19^{\text {th }}$ Uzbek Party Congress. Yet he spent a considerable amount of time discussing Uzbekistan's cotton industry and cotton production. To be sure, this is to be expected as the main task of all-Union and republic party congresses was to discuss the successes and shortcomings of the previous Five Year Plan and to set the goals for the next Five Year Plan. But Rashidov consistently used Uzbekistan's cotton monoculture as a rallying cry for patriotism. In his report to the $19^{\text {th }}$ Uzbek Party Congress, Rashidov stated “The republic's workers see their patriotic international duty to the Motherland in the increasing production of 'white gold."' This sentiment is reflected in the pages of Pravda Vostoka, the primary newspaper published in Tashkent. Almost every issue contained headlines and stories heralding the production of "white gold" and its invaluable contribution to the overall Soviet economy. Moreover, Rashidov declared in an article published in Kommunist in 1973 that "Increasing cotton production and providing the country with this valuable resource in increasing numbers is 
the primary patriotic and international duty of farmers and of all the republic's workers, our main line in economic construction."18

Rashidov's sentiments toward the Russian language and toward the Russian people remained unchanged at the $20^{\text {th }}$ Uzbek Party Congress held in 1981. This congress was a virtual repeat of the $19^{\text {th }}$ Uzbek Party Congress in that the primary focus of Rashidov's report to the Congress was cotton production and the importance of increasing this production. And as he had done at the previous congress, Rashidov only made cursory reference to the Russians while emphasizing the friendship of peoples. He stated to the Congress that the ratification of the new USSR Constitution in 1977 and of the new Uzbek SSR Constitution in 1978 "resulted in a vivid demonstration of the triumph of the unfading idea of Marxism-Leninism, the worldview of the historic victory of socialism, the global revolutionary process, the genuine democratization of Soviet society, and the unbreakable friendship and brotherhood of the peoples of the USSR led by the great Russian people." He later added that "It is the direct responsibility of the Party organizations to achieve the deeper mastery of the Russian language by all of the republic's workers. Studying Russian is not only the path to the heights of science, technology, culture, and art, but also to the vital needs of the most important economic and political tasks and it is the key to further success in all ideological work. ${ }^{19}$ In the resolutions adopted by the $20^{\text {th }}$ Uzbek Party Congress, Resolution 14 stated "The Congress commits the Party, soviet, professional union, and Komsomol organizations to strengthen work on the formation in the workers of high communist morality, acceptance of the socialist way of life, and to resolutely fight against remnants of the past in the consciousness and behavior of the peoples." The Congress also instructed the Party "to ensure the continued improvement of work for educating the workers in the spirit of Soviet patriotism and socialist internationalism, of the unbreakable Leninist friendship and brotherhood 
of the peoples of the USSR and of the deep mastery of the Russian language - the language of international communication." 20 That the instruction to the Party to improve work on teaching the Russian language only comes in Resolution 14 - out of a total of 24 resolutions issued by the Congress - suggests that the $20^{\text {th }}$ Uzbek Party Congress did not attach paramount importance to this issue.

If Usubaliev in Kirgizstan made strident calls to improve the teaching of the Russian language in his republic and heaped praise on the great Russian people simply to placate Moscow and Rashidov in Uzbekistan was simply ambivalent toward these issues, then Dzhabbor Rasulov, the First Secretary of the Tajik Party, appeared completely dismissive toward them. At the $18^{\text {th }}$ Tajik Party Congress held in 1976, Rasulov - near the end of his report to the Congress stated "We must also bear in mind that having better trained professionals in all disciplines largely depends on the youth of the native nationality having knowledge of the Russian language..." He then went on to praise the CPSU's nationality policy and Brezhnev's leadership for the successes in Tajikistan, but at no time in his speech did Rasulov herald the Russians as the Tajiks" "elder brother" or acknowledge their assistance in the economic successes in the republic. $^{21}$ At the $18^{\text {th }}$ Tajik Party Congress, the only substantial reference to the teaching of Russian in the republic came in the speech delivered by R.D. Dadaboev, the Tajik Minister of Education. He stated to the Congress that "Among the most important problems in the training and education of youth is educating them in the spirit of patriotism, internationalism, and the friendship of peoples and there is the question of further significant improvement of the teaching of the great Russian language in the schools of Tajikistan." ${ }^{22}$ Dadaboev's tone in this speech is very pragmatic - Russian must be taught to Tajik students as it is the best avenue for their educational advancement. M. Tursun-zade, the Chair of the Tajik Writers' Union, noted that the 
Russian language is the vehicle for bringing advanced culture to the Tajiks, but not before he praised the Tajiks themselves: "'Nonetheless, I want to emphasize that the peoples of the Soviet East, including the Tajiks, have not lost their national identity. On the contrary, they carefully preserve it enriching the ancient culture of the people with the best traditions of world culture especially with the great traditions of Russian culture. Thanks to the Russian language, the masterpieces of world science, art, and literature have become available to us." ${ }^{23}$ Again, the tone in Tursun-zade's speech indicates that the reference to Russian language and culture is only cursory; his real emphasis is on celebrating Tajik literature and culture. Strikingly, in the resolutions adopted by the $18^{\text {th }}$ Tajik Party Congress, there is no resolution instructing the Tajik Party to improve the teaching of Russian in the republic. Instead, there is only this resolution in relating to nationality issues: "Adopt measures for the further cohesion of multinational workers in the spirit of respect for all nations and nationalities and in the spirit of solidarity with workers from all countries. Give a principled assessment to any manifestations of national narrowmindedness or conceit. Educate all workers, especially the youth, in a feeling of love and devotion for the socialist Motherland..." 24 This resolution is likely adopted by the $18^{\text {th }}$ Tajik Party Congress to placate Moscow as it appears to be only a half-hearted commitment to live up to the principles of Developed Socialism and to attempt to root out manifestations of local nationalism.

Although Rasulov refrained from making any reference to the great Russian people and made only passing comments regarding the teaching of the Russian language in his report to the $18^{\text {th }}$ Tajik Party Congress in 1976 , his rhetoric changed slightly at the $19^{\text {th }}$ Tajik Party Congress in 1981. At this congress, Rasulov opened his report with the now-obligatory homage to Brezhnev, but in the middle of his speech he remarked, "Today we can say with pride that 
everything in our rich mountain region, everything we are proud of is a visual confirmation of the wisdom and foresight of the Leninist national policy of our party." Rasulov continued, "It is, so to speak, a sort of hymn to the materialized friendship and brotherhood of the Soviet peoples. This is the best material for educating the people of all generations in the spirit of boundless loyalty to the idea of internationalism, in the indissoluble love and loyalty to the Motherland, the native Communist Party, and in the deepest respect and gratitude to all of the fraternal peoples, and above all to our elder brother the Russian people" (emphasis added). Here, finally, Rasulov pays respect to the Tajiks' colonial power, the Russians, in the same terms used by his colleagues in the neighboring republics. But he is careful to add the phrase "the native Communist Party" and the importance of educating the Tajik people to have loyalty for this party before recognizing the Tajiks" "elder brother." Shortly after making these comments, Rasulov adds "Today, we would like to emphasize the importance of studying, along with the native language, the Russian language -- the mighty means of international communication and of strengthening the international brotherhood." 25 For the first time, then, Rasulov highlighted the need to improve the teaching of Russian in the Tajik Republic, but he is careful to point out that Russian must be studied "along with the native language." Rasulov, like Usubaliev in Kirgizstan, had to balance the interests of Moscow with the concerns of his own people. Note also that Rasulov did not refer to the necessity of teaching Russian nor to the Russians as the Tajiks' "elder brother" until the $19^{\text {th }}$ Tajik Party Congress in 1981. That he made these comments in 1981 suggests that Rasulov was responding to added pressure from Moscow as a result of the Soviet war in Afghanistan, which began in 1979. As will be discussed below, the Afghan war further complicated the Soviet nationality issue as many Soviet Muslims opposed Soviet actions in Afghanistan. Tajikistan was at the forefront of this issue as it borders Afghanistan and ethnic 
Tajiks comprise a sizable portion of the population of Afghanistan, particularly near its border with Tajikistan. Thus, in response to the Afghan war, Moscow attempted to reign in Rasulov and the Tajik Party, yet it only elicited half measures from the Tajiks as Rasulov's comments on these issues are not that extensive.

In Central Asia, the nationality components of Developed Socialism - its focus on the rapprochement of nations, the coming of the Soviet man, the Russians as the "elder brother" offering selfless assistance to the non-Russian peoples, and the emphasis on the Russian language serving as the means for inter-national communication within the Soviet Union clashed with Brezhnev's trust in cadres policy, which, it will be recalled, is in many respects a resurrection of korenizatsiia policies from the 1920s. This is because while the pronouncements coming from Moscow centered on further consolidating the Soviet Empire through economic, ideological and linguistic means, Brezhnev's reluctance to replace republic Party leaders allowed those leaders - particularly in the Central Asian republics - to entrench themselves in power, leading to the formation of quasi-fiefdoms in Central Asia. James Critchlow notes that in Uzbekistan, Rashidov "was given extensive liberty to run the republic as he saw fit, in return for his effectiveness in delivering ever more cotton to the center."26 This explains Rashidov’s comments at Uzbek Party congresses and in the press describing cotton production as a patriotic duty for Uzbeks. Critchlow adds that despite Rashidov's dictatorial rule in Uzbekistan and his suppression of his own enemies there, Rashidov's rule "opened the way for Uzbek intellectuals to write and publish, especially in the late 1960s and early 1970s, works glorifying the Uzbek nation...,27 Moreover, Critchlow states that the 1960s was "characterized by a current of derussification in such areas as language, cadres, and history. There were some efforts to expunge Russian vocabulary from the Uzbek language... and preferential treatment began to be given to 
the use of Uzbek for communications..." Furthermore, in Uzbekistan, "De-russification became overt and official, implemented through such devices as conferences held in Uzbekistan and other Muslim republics to discuss 'speech culture." Critchlow cites one Uzbek participant at such a conference held at Tashkent in 1969 as stating that the conference's purpose was "to rectify linguistic injustices of an earlier period, when numerous native words were purged from the Uzbek language in favor of Russian ones." As justification for this, Critchlow states, the Uzbek participant asserted that "the Russians themselves had purified their language through elimination of such foreign borrowings as aeroplan and gelikopter."28 Thus Rashidov's comments at the Uzbek Party congresses calling for greater emphasis on teaching the Russian language were empty words intended to placate Moscow so that he may remain in power.

\section{Resisting the Empire - The Case of Petro Shelest}

Petro Shelest served as the First Secretary of Ukraine from 1963 until his removal in 1972. During this time, he also served as a member of the CPSU Politburo. Brezhnev and his allies on the Politburo removed Shelest from power because they believed him to be too tolerant of Ukrainian nationalist manifestations. But Shelest's downfall illustrates in clear detail the persistence of regional diversity in nationality policy, the continued presence of the historical legacy from the tsarist period among the top Soviet leadership, the existence of a budding decolonization process in Ukraine, the Brezhnev leadership's reliance upon ideology to maintain the empire, and the role of inter-party politics in the realm of nationality issues.

At the $24^{\text {th }}$ Ukrainian Party Congress in 1971, First Secretary Petro Shelest made contradictory remarks regarding the nationality issue. At the beginning of his report ${ }^{29}$ to the Congress, Shelest made the standard comments heralding the virtues of proletarian 
internationalism: "The Communist Party has done and is still doing everything necessary to unite the international Communist and workers movement on the principles of Marxism-Leninism and proletarian internationalism. It is resolutely and uncompromisingly fighting against opportunism and revisionism of all kinds and against any manifestations of nationalism and chauvinism." Shelest noted later that "Inspired by the ideas of Soviet patriotism and proletarian internationalism and the wholesome sense of a united family, Ukrainian writers and artists have added many pages to the annals of the friendship of the Soviet fraternal peoples." In this section of Shelest's report, he carefully praises Ukrainian writers and literature, but nowhere in his report does Shelest mention the importance of the Russian language, nor does he even refer to the Russian people. Yet he does single out "bourgeois Ukrainian nationalists" for attack. He stated to the Congress, "In the dirty anti-Soviet chorus, a shameful role is assigned to the sworn enemies of our people - the Ukrainian bourgeois nationalists who are dastardly traitors to the Motherland, outcasts who, like dust, are dispelled by the winds of history." Shelest then implied that Zionist organizations are "especially active" and that Zionism is "a reactionary, racist, nationalist ideology that fully serves imperialism."

Shelest denounced bourgeois nationalism at the $24^{\text {th }}$ Ukrainian Party Congress in a most damning fashion. Yet Shelest did tolerate, and even encourage, manifestations of Ukrainian nationalism during his tenure as First Secretary. At the $24^{\text {th }}$ Ukrainian Party Congress, author Iu. K. Smolich stated "It is significant that many of the works by Ukrainian writers have been translated into Russian and into the languages of the other fraternal peoples. Meanwhile, we publish in the Ukrainian language the best works of writers from all socialist nations. This is the effective manifestation of the internationalist forces of our Soviet literature." That Ukrainian literature is published all over the world, Smolich claimed is "vivid evidence of the development 
of national cultures in the Land of Soviets and a demonstration of the triumph of Leninist national policy." Finally, Smolich praised Shelest: "Petr Efimovich Shelest very rightly stated the need to nurture the native language and its nation. It must be said that our literary youth lovingly refers to the Ukrainian language. And that is fine. We, men of letters, should in the first place develop and widen respect for the language." Smolich added "The enrichment of the modern Ukrainian language should take place through innovation and trade-offs with all languages of the socialist nations..." 30 In their praise for the Ukrainian language and for the Ukrainian people, Shelest and Smolich were embodying the rapprochement of nations - a key principle of Developed Socialism - but they were ignoring another key component of Developed Socialism - the Russian language as the means for inter-national communication within the Soviet Union. Neglecting the Russians and the Russian language while promoting certain manifestations of Ukrainian nationalism ultimately cost Shelest his position as Ukrainian Party First Secretary.

Shelest's public pronouncements, as illustrated by his speeches at Ukrainian Party Congresses, demonstrate that Shelest was indeed tolerant of at least limited displays of Ukrainian national sentiment, though no more tolerant than Rashidov in Uzbekistan, for example. But Shelest's true sentiments are revealed in his memoirs which were published in 1995, a year before his death. Shelest's memoirs provide the most detailed glimpse into the inner workings of the Brezhnev Politburo and into the varying attitudes of Politburo members that is yet available. Until archives from the Brezhnev era become available, Shelest's memoirs will serve as the best source, but they must be treated with some caution as his reports on the proceedings of Politburo meetings come from his recollections and are thus indirect. 
Shelest's memoirs suggest that he was a proud Ukrainian patriot who firmly believed in what he deemed "true Leninist nationality policies." He promoted the study of Ukrainian history as well as the use of the Ukrainian language, yet he strongly opposed "bourgeois" Ukrainian nationalism. He also keenly recognized that the Soviet nationality question was a complicated issue that could not easily be solved - a view that others on the Politburo shared. Yet Shelest's memoirs demonstrate that the Brezhnev leadership focused on consolidating the Soviet Empire at the expense of republic sovereignty and at the expense of native languages, particularly the Ukrainian language.

Shelest's political difficulties with Moscow began in 1965. In his memoir, Shelest writes that at the September 1965 Central Committee Plenum, Shelepin, Demichev, Suslov, and Kosygin sharply criticized Shelest and the Ukrainian leadership for not doing enough to combat bourgeois Ukrainian nationalism. Shelest writes, "But when the speeches began to mention issues related to the fact that in Ukraine there is supposedly a weak struggle against manifestations of bourgeois nationalism and that ideological work, especially among the youth, is weak and that propaganda on the friendship of peoples and that internationalist education is poorly delivered, it became clear. It was all a fabrication, just shameless lies." Shelest adds that "Whether intentional or said in the heat of the moment, it was utter nonsense and insulting. These were unfounded accusations against the leaders of the republic. It has been argued that supposedly Ukraine claims a special status and displays localism ... Some have even gone so far to say that too many people in Ukraine speak the Ukrainian language and that even the signs on the shops and street names are in Ukrainian." Moreover, Shelest states that at the September 1965 Plenum, some complained that "Sevastopol is a city of Russian fame, yet it has inscriptions in the Ukrainian language ... In general, some declared that the Ukrainian language was only a 
distortion of the Russian language. In all of this, there was shown the most rabid chauvinism, especially in the speeches by Shelepin, Suslov, Demichev, and Kosygin.” Shelest accuses Brezhnev of organizing this "libel against the Ukrainian people" for political reasons. ${ }^{31}$

Shelest's summary of the events of September 1965 suggests that he and the Ukrainian leadership were singled out for criticism primarily for political reasons. Shelest often denounces what he calls "political intrigue" in his memoirs of these proceedings. Yet Shelest's observations reveal that more than simply inter-party politics were behind the Brezhnev leadership's attack on the Ukrainian leadership. First, Shelest states that some of Brezhnev's allies were critical of the use of the Ukrainian language in public places, especially in Sevastopol. This strongly suggests that the historical legacy inherited from tsarist times were still persistent. During the $19^{\text {th }}$ century, some tsarist officials denied the very existence of a separate Ukrainian language, instead dismissing it as merely a dialect of Russian. Shelest claims that "some declared that the Ukrainian language was only a distortion of the Russian language." This attitude toward the Ukrainian language is clearly imperial in nature and is a holdover from tsarist times.

Second, Shelest's entry from 2 September 1965 further illustrates the existence of regional diversity in terms of nationality policy and republic sovereignty. Shelest writes, "Meanwhile, the case shows that the interests of Ukrainian foreign policy were ignored. Whereas in Uzbekistan and in Kazakhstan and in the Turkmen, Tajik, Kirgiz, Georgian, Armenian and Azerbaijani republics, trade bureaus had been established in 1961, they did not dare to address this in Ukraine."32

Throughout Shelest's tenure as First Secretary in Ukraine, there had been a rising tide of Ukrainian national sentiment both among the Ukrainian leadership and from the intelligentsia. 
Nahaylo and Swoboda report that in August 1965, Iurii Dadenkov, the Minister of Higher and Secondary Specialized Education in Ukraine "unsuccessfully attempted to introduce measures aimed at the gradual Ukrainization of higher education in the republic." They state that although this move came from "national Communists" in Ukraine, it was nevertheless blocked. More overt manifestations of Ukrainian nationalism came later in 1965, according to Nahaylo and Swoboda, when "a group of Ukrainian communists had issued an appeal to communists in the outside world in which they had protested against 'the Russification and colonialist policies of Moscow". They claimed further that Ukraine had become no more than a "colonial administrative-territorial region of the Russian empire." 33 Presumably, it is these manifestations of Ukrainian nationalism that prompted the Brezhnev leadership's sharp criticisms of Shelest in September 1965.

The most overt display of Ukrainian national sentiment - and the main factor that ultimately cost Shelest his position as First Secretary and his Politburo membership - came with the publication of Ivan Dziuba's book Internationalism or Russification? in 1965. In this book, Dziuba claims that Soviet nationality policy is characterized by "chauvinism, great-power ideology, national liquidationalism, national boorishness, and bureaucratic standardization.” Moreover, according to Nahaylo and Swoboda, Dziuba asserted that "Territorial unity and sovereignty are being gradually and progressively lost through mass resettlement ... and through the doubtful sovereignty of the government of the Ukrainian SSR over the territory of the Ukraine. ${ }^{, 34}$ Nahaylo and Swoboda further state that Dziuba in his book advocated for more openness on the nationality issue. While Dziuba stopped short of supporting Ukrainian independence and wrote his book from a Marxist-Leninist perspective, he did criticize the 
imperial nature of Soviet nationality policy and he hinted at the lack of clarity from Moscow on nationality issues, a point that Shelest also made in his memoirs.

It was the manifestations of Ukrainian nationalism as illustrated by Dziuba's book and other acts throughout Ukraine that ensured Shelest's downfall. The most illuminating discussion of Soviet nationality policy in Shelest's memoirs is in his recounting of a crucial Politburo meeting on March 30, 1972. At this meeting, Iurii Andropov, the KGB Chief, presented a report on "hostile propaganda" and other anti-party and anti-Soviet activities across the country. Discussion of Andropov's report quickly turned into an attack on Shelest, with each member taking turns criticizing Shelest and the Ukrainian leadership, not too unlike the Politburo meeting at which Khrushchev was removed in October 1964. Shelest himself gave a lengthy speech defending himself and his Ukrainian colleagues. He admitted that there were problems with bourgeois nationalism in Ukraine - for example he noted that "The NTS ${ }^{35}$ is closing ranks with bourgeois nationalist elements of all kinds as well as with the Zionists." Moreover, Shelest noted that "China has been working to revitalize and support émigré Ukrainian bourgeois nationalists." This comment reveals that foreign policy issues did indeed cause concern in nationality issues. Shelest also defended the Ukrainian leadership's handling of the Dziuba affair, suggesting that Kiev received mixed signals from Moscow on how to deal with Dziuba. Shelest also stated that the KGB “could not determine how and through what channels Dziuba's work got abroad" until it arrested a Belgian tourist who had been acting as an intermediary between Dziuba and other dissidents with the West. ${ }^{36}$

Shelest concluded his speech at the March 1972 Politburo meeting by stating "Nationality policy is a very complex and delicate issue that must be approached very carefully and prudently. After all, an irrational form of Russophilism [rusitsizm] can turn into anti-Sovietism. We are 
against all unhealthy manifestations and we have the power and the authority [to eradicate them]. But what kind of power is it if you do not use force and the law?"37 These final comments by Shelest are revealing. First, they demonstrate that Shelest has a fundamentally different view of the nationality issue than the rest of the Brezhnev leadership. He criticizes Russophilism as potentially dangerous (possibly imperialistic), yet none of the other Politburo members even mentioned the issue of growing Russian nationalism at this meeting. Second, Shelest's comments demonstrate that while he approves of a healthy revival of Ukrainian national sentiment, he also does not want such manifestations to go too far - he seems perfectly willing to "use force and the law" to eradicate what he deems as bourgeois Ukrainian nationalism.

The remainder of the speeches at the March 1972 Politburo meeting reveal that the Brezhnev leadership were aware that nationalism is a problem in the Soviet Union, but that they are very cautious in how to handle it. Indeed, if Shelest's reporting is correct, they are unsure of precisely how to control rising nationalism other than to step up ideological work among the youth. V.V. Grishin noted that "We need to develop practical proposals to strengthen our activities. The people do not support the hostile attacks and actions, but we cannot be complacent ... Nationalism is the greatest danger for our country." Virtually all of the Politburo members agreed with Grishin's assertion that nationalism is the greatest danger and that increased ideological work was necessary to counter this danger. There were also displays of what Shelest calls "great Russian chauvinism" at this meeting. Solomentsev declared that "Internationalism is our greatest achievement, we need more substantive work with our youth. Patriotism is the main force in the struggle for the cohesion of our people. The negative mood and the unhealthy manifestations are formed on the basis of nationalism." Solomentsev added, according to Shelest, that "In Ukraine, a lot of the signs and announcements are in the Ukrainian 
language. And how does it differ from Russian? It is only a distortion of the latter, so why do it?" Shelest notes at this point in his memoir that Solomentsev "insulted the Ukrainian people, their language, and hence their culture. He showed his great Russian chauvinism and got away with it!"

Ponomarev agreed that the "manifestation of anti-Sovietism is often connected with nationalism." He also concluded that "We need to strengthen ideological work." Conversely, Suslov was more forthright and took a harder line on the issue of nationalism in the USSR. He declared, "Different scum raise their heads and the danger of their actions should not be underestimated ... We need to tighten up our attitude with our enemies, to resolutely crack down on them, and in particular it is necessary to decide the issue with Iakir and Solzhenitsyn." Volodymyr Shcherbitskii, who would replace Shelest as First Secretary in Ukraine later in 1972, stated to the Politburo "It should be noted that in Ukraine there are manifestations of nationalism. There is a so-called correlation of 'democrats' with Zionists and Ukrainian nationalists. We have not sufficiently battled manifestations of nationalism." Shcherbitskii suggested that "Ideological work among students and the youth needs to be strengthened." Then he noted, "We inadvertently come to advance cadres who, as a rule, are Ukrainian." Shcherbitskii's speech is a direct attack on Shelest's policies of defending local Ukrainian party officials and their tolerance of Ukrainian national sentiments. Shelest in his memoir denounces Shcherbitskii's speech as "treacherous - he revealed himself to be a sycophant, a careerist, and as an unprincipled person." 38

The language issue and the equal status of the union republics were also mentioned at the March 1972 Politburo meeting as reported by Shelest. As noted above, Solomentsev criticized the use of Ukrainian on signs and announcements in the republic and degraded the language as 
only a "distortion" of Russian. But not everyone on the Politburo seemed to agree with Solomentsev's observations. Masherov stated that "The language issue is an acute problem and it must be approached with caution without affecting the national feelings of the people ... There must be respectful relations with the other peoples." Demichev's sentiments were more in line with Solomentsev: "Regarding the Russian language, it is the chief language of our country. We cannot allow a revived Skrypnikshchina in Ukraine." Demichev's comments are not as inflammatory as Solomentsev, but it is clear that he attaches great importance to the Russian language, presumably at the expense of the non-Russian languages. Yet Demichev may also have simply reiterated the already entrenched Party policy that declared Russian as the lingua franca of the USSR, a view that also is in keeping with Developed Socialism and its focus on consolidating the empire's powers in Moscow. Kosygin echoed this sentiment. He noted that "Nationality policy is a very important and complicated ideological issue ... We had a major trump card in the fight against fascism - the union of our nations." But Kosygin concluded, "It is not clear why it is necessary to study the Ukrainian language in the schools in Ukraine." Shelest added, "Here I must say that Kosygin absolutely agreed with great-power chauvinism. Under such a 'principle' study of the native language must be stopped in every union republic."

Here it should be noted that Shelest recounts a conversation he had with Brezhnev in November 1969. In a diary entry dated 3 November 1969, Shelest writes, "Brezhnev raised to me questions about alleged acts of nationalism in the republic and that allegedly the CC CPSU received a lot of letters on this issue. From the conversation, I realized that the main 'national' issue was really a language issue." According to Shelest, "Brezhnev asked me, "Why do your Politizdat and Molod' not publish literature in the Russian language?' I replied, 'Because there is the Ukrainian language and $75-80 \%$ of the population of the republic speaks it."' Shelest then 
asked Brezhnev, “And if we produce literature only in the Russian language, then who will publish it in Ukrainian? Moscow? And why is this question not placed before the other republics?" Shelest reports that Brezhnev answered these questions only with silence. But Shelest was irate - he writes, "It felt like there was some force trying to sow discord among the nations. This formulation of the question on language is a manifestation of egregious chauvinism. Is it possible that the 'boss' does not understand the bankruptcy and the harm of this question? I was upset and outraged by all of this." Shelest concluded this entry in his diary with the observation "There is a lot of 'philosophical fog', confusion, and of course the distortion of the Leninist concepts in nationality issues." From this diary entry, it is apparent that Shelest disagreed with Brezhnev's approach to the Soviet nationality issue. The Brezhnev leadership's basic strategy of addressing the nationality question through greater ideological work and a further consolidation of power in Moscow differed fundamentally from Shelest's ideas on the nationality issue. Instead, Shelest favored greater decentralization of power to the republics and believed that non-Russian languages and cultures should be allowed to develop further, albeit in the proper Leninist context.

Shelest's reporting on the March 301972 Politburo meeting makes it clear that all of the Politburo members, including Brezhnev, recognized that the nationality issue was very complex and had to be treated with care, though there were some differing opinions on the language issue as noted above. In general, all agreed that greater ideological work was necessary to combat the problem of nationalism in the Soviet Union. Though Shelest does not mention whether or not anyone provided concrete proposals as to precisely what this ideological work would entail, it is evident that the concepts of Developed Socialism would lie at the core of this ideological work. As is apparent in the speeches and articles published in the Soviet Union at this time, the 
Brezhnev leadership's ideological work focused on the principles of Developed Socialism Russian as the lingua franca of the Soviet Union, the continued flowering and blossoming of national cultures, and the preparation for the coming of communism. In essence, the Brezhnev leadership approached the nationality question through a greater emphasis on Soviet unity, which in reality meant a further consolidation of the empire. Shelest opposed this process, which ultimately led to his removal.

Moreover, Shelest's memoirs shed further light on the continued existence of regional diversity in the area of nationality policy. As was discussed in the previous section, Rashidov and Moscow - tolerated manifestations of Uzbek nationalism in his republic. Indeed, Rashidov embraced nationalist sentiments and tried to control them by declaring cotton production as a patriotic act, though many in the Uzbek intelligentsia did not share this view of cotton production. Islam was allowed to exist and develop further throughout Central Asia. Nahaylo and Swoboda report that outbreaks of nationalism were on the rise in Central Asia from the late 1960s. They note that "In April and May of 1969 ethnic disturbances were reported to have broken out in several places in Uzbekistan with rioters demanding: 'Russians, get out of Uzbekistan!' Troops had to be sent to Tashkent to restore order." There was also unrest among the Tajik population in Uzbekistan which resulted in the murder of a number of Russian administrators there. ${ }^{39}$ Yet Rashidov kept his job as First Secretary of Uzbekistan, while Shelest lost his.

The revival of national feeling in Uzbekistan and the concomitant development of Islamic culture there and elsewhere in the Central Asian republics was likely at the same level as that which developed in Ukraine under Shelest's leadership. Shelest's removal from power demonstrates that the Brezhnev leadership continued the practice of maintaining tighter control 
of the western republics than on the Central Asian republics. Shelest himself alluded to this when he complained that Ukraine was not permitted to open its own trade bureau while the Central Asian and Caucasus republics were. Moreover, Shelest also fell victim to inter-party politics. John Keep explains that Shelest "was a 'reform Communist' not wholly unsympathetic to Ukrainian national aspirations" who rose to power through Khrushchev's patronage. After Khrushchev's removal from power, conservatives within the Soviet establishment distrusted Shelest. Keep notes that "Shelest protected certain regional officials who were in trouble for their national leanings and pushed the republic's economic interests at Party forums." ${ }^{40}$ Shelest himself makes passing references throughout his memoirs to the "political intrigues" within the Brezhnev leadership and it is made clear that he was not generally favored within the Politburo.

Rashidov, on the other hand, was favored by Brezhnev and his allies on the Politburo. Yegor Ligachev, who served on the Politburo from 1985 until his dramatic break with Gorbachev in 1990, wrote in his memoirs that Rashidov "had considerable influence in Moscow. Brezhnev had shown him every imaginable kindness. The Uzbek Republic was 'sacrosanct'; only flattering articles about it were allowed in the press." In 1983, Iurii Andropov gave Ligachev the task of investigating corruption in Uzbekistan; this resulted in Ligachev inviting Rashidov to his office in Moscow and presenting him with a stack of letters from Uzbekistan complaining of the state of affairs in that republic. Ligachev describes the Rashidov leadership in Uzbekistan as a "mafia" that abused power for twenty years, culminating in the gross falsification of cotton production records during that period. ${ }^{41}$ Therefore, Rashidov had much more leeway to act in Uzbekistan than Shelest had in Ukraine due to his strong political alliance with Brezhnev. Inter-party politics played a role, then, in the perpetuation of regional diversity 
in nationality policy, but the other stronger influences from historical legacy and foreign policy concerns did more to continue such disparities in nationality issues.

Shelest's replacement in Ukraine was Volodymyr Shcherbitskii, who Keep describes as “a Brezhnev associate (and Ukrainian)" who "turned out to be an enthusiastic russifier." Keep adds that "He encouraged the 'exchange of cadres', i.e. the appointment of non-Ukrainians, and even referred to his compatriots as 'blood relatives' of the Russians." ${ }^{42}$ In his Memoirs, Mikhail Gorbachev states that Shcherbitskii's "personality was not extraordinary, he commanded prestige as someone who 'led' his republic firmly. Even more important, he was, in his own words, a steadfast follower of Bogdan Khmelnistky: a symbol of Ukraine’s unity with Russia.” Moreover, Gorbachev states "Shcherbitsky was greatly respected in Ukraine. Morally, he was one of the decent people...he resented nationalism: his internationalism would have been praiseworthy had it not gone to extremes...Under him, Ukraine produced no political leader of stature."43 Thus Brezhnev found a suitable replacement for Shelest, a Ukrainian who would uphold the more imperialist aspects of Developed Socialism.

That Shcherbitskii was a far more willing participant in Brezhnev's nationality policy is evident in his report to the $25^{\text {th }}$ Ukrainian Party Congress in 1976. In his report, Shcherbitskii noted that the previous five years have "been marked by the further strengthening of the ideological-political unity of our people, by the blossoming of the unbreakable fraternal friendship of the nations and nationalities of the Soviet Union and by the strengthening of internationalism in all spheres of social life." Shcherbitskii denounced Shelest for having "lost all contact with the republic's party organizations, the trust placed in him was not justified and he lost the moral right to be in the Central Committee of the Communist Party of Ukraine." Shcherbitskii then proclaimed the Ukrainian Party's adherence to the principles of Developed 
Socialism. He stated to the congress, "In all of this work, we proceed from the Marxist-Leninist thesis that the further rapprochement of nations and nationalities in our country is an objective process. The Party is opposed to forcing this process artificially. There is no need to as this process is due to the entire course of Soviet life." Shcherbitskii then issued a subtle warning to any remaining nationalist elements leftover from the Shelest years: "At the same time, the Party considers as unacceptable attempts to constrain the process of the rapprochement of nations under any pretext to artificially create national seclusion.” Furthermore, Shcherbitskii emphasized "The consistent implementation of the Leninist principles of the CPSU's national policy is essential to the further strengthening of the ideological-political unity of our society and to the development of a new historical community - the Soviet people - and the establishment of feelings of national pride among the Soviet people" (original in bold). Shcherbitskii reinforced his insistence upon conforming with Moscow's policy at the end of his report when he declared, "Today, from the podium of our congress, on behalf of the Communists and on behalf of all of the workers of Soviet Ukraine, we declare that we will continue to relentlessly strengthen the international unity, unbreakable friendship, and fraternal bonds of the Ukrainian people with the great Russian people and with all of the peoples of our socialist Motherland." ${ }^{, 4}$ With these remarks, orthodoxy had returned to Ukraine.

The tenets of Developed Socialism were applied unevenly across the Soviet Union in the area of nationalities policy. In the Central Asian republics, so long as republic Party leaders paid lip service to Brezhnev and to the assistance of the "great Russian people", then a certain degree of nationalism in these republics could be tolerated. Rashidov created his own fiefdom in Uzbekistan and tolerated manifestations of Uzbek nationalism, but the Brezhnev leadership allowed this to occur if proper homage was paid to Moscow. Conversely, Shelest's removal 
from his post in Ukraine reveals that Moscow would not tolerate any manifestation of Ukrainian nationalism. The continued existence of a Russian chauvinistic attitude toward the Ukrainians, inherited from tsarist times, meant that the Russians in Brezhnev's leadership would not allow much leeway in the toleration of Ukrainian nationalist sentiment. Moreover, as Ukraine lie on the western border of the Soviet Union, and thus on the front line of the Cold War, Moscow had to keep a tighter rein on this vital republic. Soviet imperialism as exercised through the policies of Developed Socialism, then, perpetuated the existence of regional diversity. 


\section{CHAPTER FIVE \\ DISSENT AND DECOLONIZATION}

\section{Introduction}

With the death of Stalin in 1953 and the subsequent thaw under Khrushchev, a growing dissident movement emerged in the Soviet Union in the 1950s and 1960s that continued into the 1980s. In general, the dissident movement in the Soviet Union involved Russians and nonRussians alike and was primarily concerned with the human rights situation in the USSR. This concern with human rights culminated in the formation of several Helsinki Watch Groups in various parts of the western Soviet Union after the signing of the Helsinki Final Act in 1975 and its requirement that the signatory states "respect human rights and fundamental freedoms" of their citizens. ${ }^{1}$

Along with human rights demands, the postwar dissident movement in the Soviet Union also had a nationalist element. Nationalist dissent can be divided into two broad categories: one, moderate opposition that focused on demands for greater cultural autonomy and opposition to Russification, and two, radical movements that demanded independence from the Soviet Union and thus the dissolution of the Soviet Empire. Moderate movements in the former category could be found all over the Soviet Union among those nations with Union-Republic status as well as among the smaller nations, especially those nations which had been deported in 1944 and had not been permitted to return to their homeland such as the Crimean Tatars and the Volga Germans. The Soviet Jews were also in this category as they simply wanted leave the Soviet Union. Dissent in the first category did not advocate for independence. 
Radical dissent in the second category, however, did call for the independence of their respective nations and was concentrated in the western Soviet Union and in parts of the South Caucasus. This more extreme form of nationalist dissent was most widespread in the three Baltic republics and in western Ukraine with some activity also taking place in Moldavia and Armenia. Independence movements were concentrated in the western regions of the Soviet Union for several reasons. First, the three Baltic republics, the western regions of Ukraine, and Moldavia were acquired as a result of the Secret Protocols attached to the Nazi-Soviet Non-Aggression Pact of 1939 and thus Soviet power in these areas was imposed by Soviet aggression and not through the conditions of the October Revolution and subsequent civil war. The Baltic republics enjoyed a period of independence, whereas the other areas annexed in 1940 had been separated from Russia. Therefore, the imposition of Soviet power here was regarded by the peoples in these regions as Soviet colonialism, especially in the Baltic republics. Second, as has been discussed throughout this study, Moscow always retained a tighter control over the western republics, which, combined with the more imperial nature of the acquisition of the three Baltic republics, western Ukraine, and Moldavia, provoked more nationalist sentiment. In contrast, no independence movements existed in the Central Asian republics where Moscow's control was a bit looser, though, as Chapter 4 demonstrated, nationalist dissent did exist there, particularly in Uzbekistan.

This chapter will focus on the nationalist dissent movements in the western Soviet Union and in the South Caucasus as these dissident movements were the most anti-colonial in nature. I will begin with a discussion of the imposition of Soviet power in the Baltic republics and the subsequent development of nationalist dissent in these republics to demonstrate that a decolonization movement was forming in these republics throughout the Brezhnev period. 
Subsequent sections of this chapter will focus on nationalist dissent movements in Ukraine, the South Caucasus and in Moldavia.

This chapter will conclude with an evaluation of the Brezhnev leadership's response to the nationalist dissident movement. In general, the Brezhnev leadership appeared relatively unconcerned about the nationalist dissident movement; they did not regard it as a major threat to the Soviet regime and they were largely correct in this assessment. The Brezhnev leadership's strategy for dealing with nationalist dissent consisted of a two-pronged approach that relied on repression and arrests as well as continued focus on the tenets of Developed Socialism, which called for the greater consolidation of the Soviet Empire. In addition, the Brezhnev leadership often blamed foreign influences whether from Western intelligence agencies or from émigré groups for manifestations of nationalism in the USSR. Notably, the authorities regarded nationalist dissent in general as "ideological subversion", which suggests that further educational work on "internationalism" would help stem the problem. In part, the Brezhnev leadership's response to nationalist dissent - and to dissent focused on human rights - culminated in the drafting of a new USSR Constitution in 1977 and of new Union-Republic constitutions in 1978, which will be discussed in the next chapter.

This chapter is not intended to be an all-encompassing review of dissent in the Soviet Union. The focus will be on case studies of nationalist dissent to show how they can be interpreted as a component of the general pattern of decolonization occurring in the Soviet Union during the Brezhnev years. Therefore, dissidents who belonged to Helsinki Watch Groups and others who protested against the Soviet system for reforms addressing human rights issues will not be examined. Moreover, the focus of this chapter will be on nationalist dissent that opposed Russification and other policies that were regarded as degrading to non-Russian cultures and 
peoples as well as dissent that demanded independence from the USSR. Therefore, the efforts of Soviet Jews to emigrate to Israel will not be examined at length as they wanted to leave the USSR and thus they did not demand autonomy or the territorial breakup of the Soviet Union as other nationalities did.

\section{The Baltic States \& Soviet Imperialism}

The three Baltic republics of Estonia, Latvia, and Lithuania have been described as "modern creations with histories of less than a hundred years." 2 Since the Middle Ages, the Estonians, Latvians, and Lithuanians were subjected to foreign rule, either by the Germans (Estonians and Latvians), the Danes (Estonians), the Swedes (Estonians), and later the Poles and the Russians. Only the Lithuanians enjoyed independence in the early Middle Ages before accepting a personal union with Poland in $1386 .^{3}$ By the nineteenth century, all three Baltic peoples had come under Russian rule.

The chaos of World War I and the Russian revolutions of 1917 created the opportunity for Estonia, Latvia, and Lithuania to declare independence in 1918. For the first time in their respective histories, the three Baltic nations were independent and could build nation-states. However, with the rising power of Nazi Germany and the Soviet Union through the 1930s, the Baltic states' independence would be short-lived. As a result of the Secret Protocols of the NaziSoviet Non-Aggression Pact signed in August 1939, the Soviet Union was free to annex the three Baltic republics along with eastern regions of Poland, and Bessarabia. By the end of 1940, all of these regions had been absorbed into the Soviet Empire.

The Soviet takeover of the three Baltic republics followed a similar pattern in all three cases. Already by fall 1939, all three republics had been pressured to sign mutual assistance and 
defense pacts with Moscow. This was accompanied by the stationing of Soviet troops on the territories of the three Baltic republics - 30,000 in Latvia, 25,000 in Estonia, and 20,000 in Lithuania. The Soviet military contingents in Latvia and Estonia were larger than the national armies in these republics. ${ }^{4}$ By early 1940 , Moscow began accusing all three Baltic governments of violating their defense treaties with the Soviet Union, though Moscow stopped short of accusing them of colluding with the Germans. This gave Moscow the pretext for beginning the formal annexation of the three Baltic republics.

In each republic, the Soviet takeover began with the Moscow-imposed formation of “transitional 'People's Governments'. Cabinet lists were presented by the Soviet emissaries, who refused to sanction even minor changes." Because the Communist Party in each republic was small (and had been declared illegal in all three republics in the 1920s), the Soviets had to create coalition governments of leftist forces "including several prominent opponents of the previous regimes." Theoretically, these coalition governments were formed according to the constitutions still in force in all three countries, though in Lithuania the legality of the Sovietimposed coalition government was in most doubt as the Lithuanian President had fled the country without formally resigning and the Acting President - Antanas Merkys - had previously resigned as Prime Minister. This raised the constitutional question as to whether Merkys really was serving as President. The Soviets circumvented this difficulty by claiming that the Lithuanian President had resigned by virtue of his fleeing the country. In Estonia and Latvia, the process was simpler; the presidents of both countries refused to endorse the Soviet-proposed cabinet lists, which 'led to the organization of 'popular' demonstrations by the 'masses' - a mélange of Communist sympathizers, some of the recently released prisoners, civilian Soviet 
workers at Soviet bases, and Soviet military and naval personnel specially lent out and accompanied by armored cars for the occasion."

Once the Soviet-backed cabinets had been formed in each country, the former leaders of Estonia, Latvia, and Lithuania were arrested and deported to the USSR. But the Soviets were careful to avoid the appearance that they were taking over these states. Indeed, Andrei Vyshinskii - Moscow's representative in Latvia - ended an address to pro-Soviet demonstrators in Riga by proclaiming in Latvian, "Long live free Latvia! Long live the unbreakable friendship between Latvia and the Soviet Union!" ${ }^{6}$ Soviet pretentions of maintaining the independence of the Baltic states were short lived, however. After much persistence, the Lithuanian Foreign Minister, Vincas Kreve-Mickevicius met with Viacheslav Molotov in Moscow on June 30, 1940. At this meeting, Molotov indicated that Moscow intended to absorb the Baltic region and he told Kreve-Mickevicius "You must take a good look at reality and understand that in the future small nations will disappear. Your Lithuania along with the other Baltic nations, including Finland, will have to join the glorious family of the Soviet Union."

In July 1940, elections were held for People's Assemblies in all three Baltic states. By all accounts, these were sham elections conducted by the Soviet occupation forces. In all three states, threats were used to force people to vote in order to ensure as high a turnout as possible "and thus legitimize the new system." Despite such threats, in Lithuania, turnout was so low that the Lithuanian cabinet extended voting for one day. Official results showed that in Lithuania, the Soviet-backed candidate list won 99.2 percent of the vote; in Latvia, 97.6 percent; and in Estonia, 92.2 percent. With the election of these new People's Assemblies, the incorporation of the three Baltic states into the Soviet Union was openly proposed and discussed. By late July, 1940, the assemblies in all three states established Soviet-style governments and formally 
requested incorporation into the Soviet Union. On August 3-6, all three had been granted entry into the Soviet Union thus completing the process of the Soviet takeover of the three Baltic states. $^{8}$

The Sovietization of the economy, culture, and society accompanied the imposition of Soviet power to the three Baltic states. The nationalization of industry and the beginning steps of the collectivization of agriculture took place in the Baltic republics starting in the summer of 1940. Sovietization also included repression and mass deportations of undesirable elements, which sparked the first resistance movements to Soviet rule. While arrests of prominent pre1940 leaders began as early as during the elections of summer 1940, mass waves of deportations occurred in 1941. The largest wave of deportations came on the night of June 13-14, 1941, just a week before the German invasion of the USSR. It is estimated that 15,081 Latvians, 10,205 Estonians, and 34,260 Lithuanians were deported to labor camps in June 1941. 9 Moreover, “The general estimates of population losses from all causes - deportations, mobilizations, massacres and unexplained disappearances during the first year of Soviet rule - hover around 60,000 for Estonia ... 35,000 for Latvia; and 34,000 for Lithuania.” If this is correct, the losses amount to 4 percent of Estonia's population, 1.5 percent of Latvia's population, and 2 percent of Lithuania's population. $^{10}$

The brutality of the first year of Soviet rule engendered resistance in the Baltic states. Most opposition was passive, involving boycotting political activity. The most organized resistance group was the Lithuanian Activist Front, which formed in October 1940 and, with German approval, established contact with the former Lithuanian ambassador to Germany. When the Germans invaded in summer 1941, they were often greeted with flowers by the Baltic peoples. Most Baltic peoples, however, welcomed the Germans more passively and the "feeling 
seems to have been pervasive that the overthrow of the Soviet yoke by the Germans would enable the Baltic peoples to reassert their national independence." ${ }^{11}$ Ultimately, German rule was not an improvement over Soviet rule as the German occupation forces mobilized Baltic labor and the Germans had no intention of granting independence to the Baltic peoples.

The return of Soviet rule in 1944 brought a new wave of repression, deportations, and a reinvigorated push to Sovietize the three Baltic republics. Between August 1945 and February 1946, some 100,000 people were deported from Lithuania, an estimated 60,000 were deported from Latvia over the same period. ${ }^{12}$ Romuald Misiunas and Rein Taagepera argue that "If the goal of the deportations was to break national resistance, the results were mixed. Expectations of being next in line for deportation made many desperate people join the guerillas in order to die fighting on native ground rather than of starvation in Siberia." ${ }^{\prime 13}$ Guerilla movements, known as the Forest Brothers, developed in all three republics in 1945. At their peak, 0.5 to 1 percent of the population fought in Forest Brothers detachments, forcing tens of thousands of MVD and Red Army troops to be stationed in the three republics, especially Lithuania, for several years after the war. ${ }^{14}$ In Lithuania, armed resistance against Soviet rule continued until $1953 .{ }^{15}$

The guerilla fighting against the imposition of Soviet rule in the Baltic states is similar to other guerilla movements against imperialism in other parts of the world. In 1832, a guerilla movement arose in Algeria against the imposition of French rule there that lasted for fifteen years. Extreme violence against French rule erupted again in Algeria in 1954, ultimately leading to Algeria's independence. Similarly, Ho Chi Minh's Vietminh movement initiated guerilla warfare against the re-imposition of French rule in Vietnam in 1945, which also ultimately led to Vietnam's independence, though not without first defeating American troops. While the activities of the Forest Brothers in the Baltic republics did not lead to independence (at least not 
immediate independence), it was similar to other violent independence movements around the world in the twentieth century. ${ }^{16}$

The period from 1945 to Stalin's death in 1953 was marked by the re-Sovietization of the Baltic republics including the collectivization of agriculture, rapid industrialization, the rebuilding of the Communist Party in each republic, and the Sovietization of culture. These activities set the stage for postwar resistance in each of the Baltic republics. Industrialization in Estonia and Latvia, for example, was accompanied by an influx of Russian and other Slavic immigrants to work in the new factories. As a result, in the decades after the war, up to 40 percent of the population of Estonia was non-Estonian while in Latvia, the Latvians only comprised 50 percent of the population. ${ }^{17}$ As will be discussed in the next section, the influx of Russian and other Slavic immigrants in Estonia and Latvia and the accompanying Russification of culture provoked much protest in the 1960s and 1970s. Economic changes and the formation of settler communities was also the pattern in Algeria and in other colonies around the world.

Party membership and leadership also posed problems in the Baltic republics after the war. To begin with, party membership in each republic was low and a sizable proportion of these party members were either "foreign", i.e. Russians or Ukrainians, or were members of the titular nationality who had emigrated to Russia before 1918 and were therefore Russianized. The best example of this was in Estonia where after the war, a large contingent of "Yestonians" came to implement the Sovietization of the republic. Native Estonians referred to these imported Party officials as Yestonians "because that was how their Russian accent made them pronounce the word eestlased (Estonians)."18 Yestonians and their counterparts in Latvia only reinforced the attitude among Estonians and Latvians that the Soviet regime was an occupation regime and thus lacked legitimacy. 
Given the nature by which the Soviet Union absorbed the Baltic states, it is easy to categorize Soviet actions as purely imperialist while the Baltic peoples simply identified themselves as colonial or occupied subjects and thus all forms of Baltic nationalism resisted the "Soviet occupation." However, recent research reveals that the situation in the Baltic after World War II was not so clear-cut. An example of the complexity of the situation in the Baltic is the nature of post-war Lithuania. When the Soviet Union annexed Lithuania in 1940, it also readjusted the former Lithuanian-Polish border in order to transfer the city of Vilnius to the new Lithuanian Soviet Republic. During the interwar years, Lithuanian nationalists had declared Vilnius a Lithuanian city that should be rightfully returned to Lithuania. Ironically, Soviet imperialism achieved this goal of Lithuanian nationalists.

Violeta Davoliute describes postwar Lithuania as an "'imperial situation” - a heterogeneous space of conflicting memories and political, social, and cultural experiences created by forced and momentous geopolitical, demographic, and social changes." The process of Sovietization in Lithuania and its associated economic, social, and cultural changes, "not only crushed Lithuanian sovereignty and repressed political freedoms, but catalyzed (generally in a distorted nature) longer-term, transnational processes of modernization like urbanization and the development of mass politics and culture." Davoliute argues that Sovietization created a condition she calls the "imperial sublime" in Lithuania especially in regard to Vilnius as the Sovietization of Lithuania actually provided a link between Lithuanian national identity dating to the $19^{\text {th }}$ century and the formation of a modern Soviet Lithuanian identity. ${ }^{19}$

Although the city of Vilnius did not figure prominently in traditional Lithuanian folklore, during the interwar years, the Lithuanian regime sought to mobilize the masses "to assert its historical sovereignty vis-à-vis Poland" and "to reclaim the city of Vilnius for the building of a 
modern Lithuanian identity." ${ }^{20}$ After the war, Vilnius was used by Soviet Lithuanian authorities to build and promote a new modern Soviet Lithuanian identity. Moreover, song festivals, which were prominent features of cultural life for Estonians, Latvians, and Lithuanians, were used by the Soviet Lithuanian authorities to promote the new Soviet Lithuanian identity. ${ }^{21}$ Antanas Snieckus, First Secretary of the Lithuanian Communist Party from 1940 until his death in 1974, actively worked to preserve Lithuanian identity during the period of Sovietization and for many years after. One Lithuanian dissident actually praised Snieckus in the 1960s writing that Snieckus "is an example of the kind of statesman who attempts to preserve a sense of nationhood under the conditions of occupation."22

Soviet rule in the Baltic republics began as occupation in 1940, but as resistance to Soviet rule became futile and dissipated by 1953, the Soviet occupation evolved into a Soviet colonial system. The turning point came in the mid-1950s as "the general population in the Baltics started to collaborate with the new regime." The number of ethnic Estonians in the Estonian Communist Party, for example, rose from 9,729 in 1953 to 50,000 in 1981. This was not "because of any growing faith in communist ideology, but rather because of a growing realization that the new regime was incontestably established and would be in place for the foreseeable future." After Sovietization, "the economic, cultural, and social models at work were colonial: foreign supremacy and military control over the annexed territory, reconstruction of the economy of the territory in order to serve the interests of the colonizers, appropriation of goods and products from the colonized territories into the center of the empire, and careful screening of all cultural activities." ${ }^{23}$ A similar process occurred in Moldavia and in western Ukraine as well. 
Thus the acquisition of the Baltic states was achieved through occupation, which evolved into a Soviet colonial system. Though most Estonians, Latvians and Lithuanians grew to at least tolerate, if not accept, Soviet rule by the mid-1950s, nationalist elements remained in these republics which would develop into dissident movements in the 1960s and 1970s. As the next section reveals, nationalist dissent in the Baltic republics frequently referred to the "Soviet occupation" and the influx of Russian settlers, especially in Estonia and Latvia, acted to provoke much dissent.

\section{Nationalist Dissent in the Baltic - Russians Get Out!}

Nationalist dissent in the three Baltic republics fell into the two categories described at the beginning of this chapter - demands for cultural autonomy and calls for national independence from the Soviet Union. A common strand, however, is that nationalist dissent in the Baltic republics frequently referred to the Soviet regime as an imperialist regime that was occupying the three Baltic republics. Such rhetoric further demonstrates that the three Baltic republics represented the most imperialist aspect of Soviet rule.

On July 25 and 26, 1985, the Baltic World Conference, representing the Estonian World Council, the World Federation of Free Latvians, and the Supreme Committee for Liberation of Lithuania, conducted a tribunal in Copenhagen at which they put the Soviet Union on trial. The purpose was "to bring to the attention of the world the illegal Soviet occupation of the once free and independent Republics of Estonia, Latvia and Lithuania; to document the atrocities and genocide committed against the Baltic people; and to condemn the Soviet Union for these acts

against humanity."24 A panel of "judges" was formed to hear testimony from dissidents who had left the Baltic republics and then to present an indictment against the Soviet Union based on this 
testimony as well as on evidence in the historical record. The Tribunal was obviously not impartial - the verdict was likely already decided before it even convened - but the materials produced by the Tribunal and the witnesses who testified provide a good glimpse into the mindset of the Baltic opposition to Soviet rule. These materials also provide further evidence of the imperial nature of Soviet nationality policies and of the Brezhnev leadership's strategy of dealing with nationalist dissent.

The use of colonial language is prominent in the "indictment" against the Soviet Union in the Tribunal's materials. For example, the Tribunal accused the Soviet Union of "economically exploiting Estonia, Latvia and Lithuania. Accelerated industrialization is used to gain greater political control over the Baltic States, but not to improve their economies or to make them more efficient." Moreover, "The Soviet Union, in exercising its colonial-master's powers, discriminates against the ethnic Balts in employment, housing, education, communication, the arts, and other endeavors and services." The Tribunal also asserted that "Soviet colonial rule in Estonia, Latvia and Lithuania, based on alien Russian domination and exploitation, constitutes a violation of the United Nations Organization's Charter and is especially a violation of the Declaration on the Granting of Independence to Colonial Countries and Peoples of December 14, 1960. ${ }^{25}$ To the members of the Tribunal, then, Soviet rule in the Baltic was clearly imperialistic and thus the Soviet Union was an empire.

The Tribunal also included Soviet industrialization policies and the accompanying influx of Russians and other Slavic peoples into the Baltic republics in its indictment against the Soviet Union. Using Latvia as an example, the Tribunal noted that due to industrialization, the Latvian share of the population fell from 75.5 percent before 1940 to 53.7 percent while the Russian/Slavic share of the republic's population rose to 42.1 percent. The Tribunal concluded 
that "The politicized industry has thus served the implementation of Soviet colonization plans." The Tribunal even compared Soviet policy to Portuguese efforts in Mozambique: "A gigantic dam, known as Cabora Bassa, was built in order to create the economic preconditions for the settlement of a million or so Portuguese colonists in Mozambique who would support the colonial regime.",26

The testimony presented at the Tribunal provides evidence that nationalist opposition in the Baltic republics involved both resistance to cultural and linguistic Russification as well as demands for independence. Rita Bruvere, a Latvian, testified that "The learning and use of Russian is, through many channels, forced upon Latvians in their own country ..." She added that since the All-Union Scientific and Practical Conference on Russian - the Language of the Friendship and Collaboration of the Peoples of the USSR held in Tashkent in May 1979, "there has been a campaign for the intensification of Russian language teaching to children, starting even in kindergarten." Moreover, Bruvere testified that teachers of the Latvian language were typically Russian who had "a weak command of Latvian". She also noted that "in recent years Latvian pupils have demonstratively failed to study the Russian language, and, as a protest, have received low (failing) marks in Russian." This is an example of passive resistance to Soviet rule in Latvia.

Bruvere ended her testimony with a rather poignant observation: "disinformed Western journalists have started calling all people from the USSR Russians (or Soviet Russians, which in itself is an illogical construction), and so even here, in the free world, the feelings of the oppressed people are offended. Thus the Western news media unwittingly reinforces the Soviet efforts to convince the Baltic people that they are no longer Estonians, or Latvians, or 
Lithuanians, but instead are Russians." As will be discussed in the next section, the prominent Ukrainian dissident Ivan Dziuba made a similar accusation in the 1960s.

Bruvere's testimony serves as an example of dissent against the cultural and linguistic Russification of the Baltic republics. Other witnesses provided similar testimony. But the Tribunal also heard evidence of the existence of independence movements in the Baltic. Gunnars Rode, a Latvian, stated at the Tribunal that he was arrested in 1962 and sentenced to 15 years for "1. Holding nationalist sentiments; 2. Disseminating the idea of forming a Baltic Federation independent of the Soviet Union; 3. Anti-Soviet propaganda; 4. Organizing activities intended to foster the independence and freedom of the nations subjugated by the USSR; 5 . Drawing up plans that were perceived as undermining the Soviet Union ..." Rode also stated that between 1958 and 1962, he was one of the leaders of the Baltia underground association and that he "participated in discussions concerning the possibility of a Soviet republic to secede from the Union." 27 Along similar lines, Sergei Soldatov testified that from 1966 he participated in the Democratic Movement of Estonia, whose "goals included the restoration of the Republic of Estonia, and guarantees for a free society and human rights." In 1972, Soldatov helped write the DME's Memorandum to the UN General Assembly and the organization's Letter to the UN Secretary General. Soldatov stated that these two documents "called for the removal of Soviet forces from Estonia, the liquidation of the apparatus of colonial rule, the organizing of free elections, and the formation of a Government of the Republic of Estonia."28

Other forms of nationalist dissent were reported on in the samizdat journal Chronicle of Current Events. In 1971, the Chronicle reported the trial of Simas Kudirka, who attempted to board an American cutter in U.S. territorial waters. Kudirka delivered a speech at his trial that lasted for four hours. In his speech, Kudirka stated that "he had not betrayed Lithuania, his 
fatherland; and he did not regard Russia, now called the Soviet Union, as his fatherland." He also "made a single request of the Supreme Court and Government of the USSR - to grant Lithuania her independence." 29

It appears that by the 1970s, Lithuania had the most organized and most extensive nationalist dissent among the Baltic republics. Indeed, by 1973, the Chronicle began devoting an entire section to activities in Lithuania entitled "Events in Lithuania." Among these "events" were KGB efforts to break up the activities of "ethnographic and regional studies groups" that had formed in Vilnius. Reportedly, the KGB asked participants in certain of these groups, "Why sing only Lithuanian songs?' The charges of nationalism sometimes took on a sharper character. 'Why sing partisan songs?' 'Why gather materials on partisan battles?"30 Lithuania was also the site of more extreme displays of nationalism. On May 14, 1972, Romas Kalanta died by selfimmolation at a public square in Kaunas under a banner that read "Freedom for Lithuania." A couple weeks later, a man named Stonis also died by self-immolation in Varena, a day after he and three friends flew a Lithuanian flag in the public square. ${ }^{31}$

Most nationalist-inspired acts of dissent involved relatively simple acts of individual passive protest. An example is the arrest in November 1976 of Julius Sasnauskas. He had been arrested for lighting candles at the graves of important Lithuanian national leaders who fought for Lithuania's independence in 1919-1920. The KGB major who interrogated Sasnauskas "beat him up for refusing to speak Russian." The major then pointed to his colleague and told Sasnauskas, “This is your teacher of Russian. In a couple of days he'll teach you so that no one will realize that you're not Russian." ${ }^{, 32}$

The largest display of Lithuanian national protest came in October 1977. After a football match on October 7, a few hundred spectators took to the street near the stadium in Vilnius 
celebrating their team's victory and shouting slogans such as "Down with the Constitution!"; "Freedom for Lithuania!"; and "Russians - clear off!". The crowd also flew Lithuanian flags. That this demonstration occurred at the time that the new USSR Constitution was being adopted is no coincidence. As will be discussed in the next chapter, the new USSR Constitution adopted in 1977 and the new Union-Republic constitutions adopted in 1978 provided for greater concentration of power in Moscow at the expense of the Union Republics in keeping with the tenets of Developed Socialism. In part, the Lithuanian football protestors likely were agitated by the new provisions of the USSR Constitution. At the very least, the official propaganda unveiling the new constitution - and its emphasis on greater unity and internationalization of the Soviet peoples (a codeword for greater Russification) likely would have provoked nationalist sentiments.

A few days later on October 10, an even larger demonstration took place on the streets of Vilnius. On this day, the Vilnius football team was hosting a team from Smolensk. During the game, anti-Russian shouts could be heard from the spectators, which could also be heard on the television broadcast of the game. Once this began, the television transmission was cut off "for technical reasons." Despite a heavy troop presence around the stadium, after the game up to 15,000 spectators took to the streets of Vilnius overturning police cars. This time, unlike the event on October 7, Russian protestors were among the Lithuanians. Some Russians shouted "Russians are here with you too!" and "For your and our freedom!" The protest on October 10, then, was not exclusively driven by Lithuanian nationalism - some elements in the crowd appeared to simply protest the Soviet regime in general. During both the October 7 and October 10 protests, posters heralding the new Constitution were ripped down as were posters celebrating the $60^{\text {th }}$ anniversary of the October Revolution. 
An unknown number of people were detained after the demonstrations. Reportedly, 17 cases were heard by the Procuracy in one district of Vilnius in November. In addition, several people were expelled from institutes of higher education as well as from the Komsomol. All football matches for the remainder of October were cancelled; a match scheduled for November was allowed to be played but tickets were only available to certain enterprises and were distributed only to those deemed by the Party to be reliable. The local Vilnius newspaper denounced what it called acts of "hooliganism" and a Vilnius footballer even published an article condemning the events of early October. ${ }^{33}$

Other incidents in Lithuania in late 1977 included the slogan "Russians - get out of Zemaitija!" written on all of the posters celebrating the anniversary of the October Revolution in the town of Telsiai. Zemaitija is a region in Lithuania. On the fourth floor of the building housing the town soviet in Salcininkai was written in large letters, "Long live a free Lithuania!" and "Down with the Russians!",34

In Lithuania, the Catholic Church served as a focal point for dissent in general as well as for Lithuanian nationalist dissent. Catholicism forms a key part of Lithuanian national identity and the most prominent samizdat journal that appeared in Lithuania was The Chronicle of the Catholic Church in Lithuania. Though the Lithuanian Catholic Church, like all other religions in the Soviet Union, was under the supervision of the Council of Religious Affairs, it still remained a rallying point for Lithuanian nationalists and the Soviet state was never able to exercise effective control over the Church. The CPSU even noted that "the church portrays itself as the true guardian of the nation's cultural heritage and has frequently accused priests of instigating nationalism among the faithful. In turn, some Catholics insist that only believers can be Lithuanian patriots." 
Lithuania performed a similar function as Islam did in Central Asia. As discussed in Chapter 4, due to its de-centralized nature and its pervasiveness in the cultures there, Islam remained an important part of identity among the peoples of Central Asia that the Soviets were never able to control fully. Although the Catholic Church was far more visible and centralized in Lithuania than Islam was in Central Asia, the Soviet authorities could never bring the Church firmly under their control or influence.

Since the establishment of Soviet rule in Lithuania, the Soviet authorities tried to eradicate or to control the Catholic Church. These efforts included restricting Catholic education, the arrest and deportation of priests and other Church officials, efforts aimed at preventing children from learning the catechism, the closing of monasteries and the closing of churches across Lithuania. ${ }^{36}$ Moreover, at various times, Moscow sought either to attach the Lithuanian Catholic Church to the Russian Orthodox Church, or to sever the Lithuanian church's link with the Vatican and to create a national church in Lithuania.

Just as the Soviet authorities closed mosques and madrassas in Central Asia, while allowing a limited number of "official" mosques and madrassas to remain open, similar steps were taken in Lithuania vis-à-vis the Catholic Church. In Lithuania, only one seminary was permitted to remain open but all students admitted to the seminary had to be approved by the LSSR KGB. Moreover, the KGB worked to recruit seminary students as well as clergy to collaborate with KGB surveillance activities. KGB harassment led to the formation of an underground seminary in Lithuania in $1971^{37}$, just as underground imams were providing illegal religious instruction to Muslim students in Central Asia. Thus, Catholicism in Lithuania performed similar functions as Islam did in Central Asia as both belief systems evaded Moscow's complete control. 
The Chronicle of the Catholic Church in Lithuania was devoted primarily to reporting acts of Soviet repression against the Church such as the arrest of priests and other clergy or the harassment of believers. But it also contained reports of dissent in Lithuania, some of which were of a national character. The best example of this is a letter addressed to KGB Chair Iurii Andropov entitled "Way of Calvary" and written by Antanas Terleckas. ${ }^{38}$

In his letter, Terleckas recounted years of harassment at the hands of Soviet authorities dating to the 1940s. He also informed Andropov of problems in relations between Russians and Lithuanians. Terleckas began working at the Lithuanian branch of the USSR State Bank in 1954 where he was the only Lithuanian working in his department. He writes, "Russians who had worked here for ten or more years ... knew not a single word of Lithuanian and nothing about Lithuania. I could not convince them that the Lithuanian language was not a German dialect ..." He added "I had to explain that the national consciousness of Lithuanians was superior to the national awareness of the nomads of the Soviet North." Terleckas then lectured his co-workers on Lithuanian history; they were incredulous when he told them that Lithuania had once ruled cities such as Kiev, Minsk and Smolensk. At this point, "the rumor started that I was a nationalist. Complaints began to flow to the KGB. The bureaucrats persuaded Manager Knyva to remove me from the office."

After serving a sentence in the labor camps for his alleged participation in an underground Lithuanian nationalist group, Terleckas returned to Lithuania where he attempted to pursue a doctoral degree in history. Upon his return to Lithuania, Terleckas continued to be detained and questioned by the KGB. During one interrogation, the KGB captain again accused Terleckas of being a nationalist. Terleckas then asked his interrogators, "why Russians, Arabs and Africans are proud of their nationalism, but a Lithuanian must be ashamed of his. Why love 
of Russia is considered Soviet patriotism, but love of Lithuania a bourgeois nationalist?" He did not receive an answer; instead, he was instructed to publish an article in the local press recanting his views. Terleckas refused.

On another occasion in which the KGB interrogated Terleckas, this time on charges that he had financed "the nationalist underground", Terleckas engaged in a conversation with his interrogator on the subject of nationalism. Terleckas "agreed that small countries must be assimilated. But the loss of their identity will take place over several centuries and, therefore, I saw no need to accelerate it by artificial means." His interrogator, Major Lashchenko, disagreed. He stated to Terleckas, 'the natural process of assimilation is 'painful,' and for that very reason all means used to accelerate the blending of nations is justified." Lashchenko ended the conversation with the statement: "You did not see how we crushed the Hungarian uprising. If you had seen it, you Lithuanians would not raise your heads. Lithuania! Your Lithuania is like a flea, see (he made an expressive gesture with his thumbnail) and it is gone!" Terleckas's letter to Andropov, then, reveals not only the tensions that existed in Lithuania between Lithuanians and Russians, but also the imperial nature of Soviet rule in Lithuania.

Nationalist dissent in the Baltic republics, then, consistently decried what the dissidents regarded as the imperial nature of Soviet rule in Estonia, Latvia, and Lithuania. Dissidents in Estonia and Latvia resented the influx of Russian and other Slavic immigrants to their republics that accompanied the industrialization component of Sovietization after 1945. Thus, "in Latviaas in all of the other Baltic states - slogans appear on walls both inside and outside official buildings: "Russians, get out of Latvia!" "Russians go home!” These slogans were written in Russian "so that occupiers can read them." Moreover, "The desire for independence is manifest also by flying the national flag, particularly on November 18, Memorial Day."39 Similar 
sentiments prevailed in Lithuania as well, though Russian/Slavic immigration to that republic was not as extensive as it was in Estonia and Latvia. Moreover, the Catholic Church served an important role in the Lithuanian dissident movement.

\section{Ivan Dziuba and Marxist-Leninist Dissent in Ukraine}

Nationalist dissent in Ukraine, as elsewhere in the western Soviet Union, involved resistance against Russification and the concomitant defense of national culture and language, along with overt acts of seeking independence. Alexeyeva notes that among those nations with Union Republic status, "the first movement to emerge in the 1960s was the Ukrainian movement. Its aspiration was to resist the Russification of the republic and to insist on equal rights and democratization for the Ukraine. ${ }^{, 40}$ Complicating matters in Ukraine, however, was the dichotomous nature of the Ukrainian republic. The western regions of Ukraine, including the city of Lviv, were incorporated into the Soviet Union at the same time that the Baltic republics and Moldavia were absorbed. Moreover, eastern Ukraine had a large Russian population whereas western Ukraine did not. As a result of these factors and as a result of the legacy of World War II in western Ukraine, most of the demands for Ukrainian independence came from the western regions, whereas those groups and individuals centered in Kiev and in the east were more interested in defending Ukrainian culture and the Ukrainian language from Russian encroachment. The latter form of dissent was at least tolerated by some Ukrainian Party leaders such as Petro Shelest, as was discussed in Chapter Four. Additionally, there was a strong strain of "national communism" among the dissidents interested in defending Ukrainian culture and the Ukrainian language from Russification. These dissidents did not support Ukrainian 
independence per se, but merely demanded that Moscow adhere to what the dissidents considered to be true Leninist nationality policy.

This section will examine Marxist-Leninist national dissent in Ukraine. It will begin with a discussion of Ivan Dziuba and his important work, Internationalization or Russification? Dziuba's work will be used as the primary example of the Marxist-Leninist national form of dissent that became prominent in the 1960s and 1970s. It will also be shown that Dziuba was just the latest in a line of such Marxist-Leninist national thought that existed in Ukraine since before 1917. Dziuba's work can be classed as an example of anticolonialist thought that had become prevalent among colonial peoples throughout the world in the twentieth century. Dziuba's Marxist-Leninist critique of Soviet imperialism was similar to other nationalists around the world such as Ho Chi Minh who fused nationalism with Marxism-Leninism to lead decolonization movements in their respective colonies.

The Ukrainian national movement re-emerged in the 1960s. Participants in this movement were known as the "generation of the sixties" - they "renewed Ukrainian cultural life, which had almost died out in the Stalin period, and brought to it a sincerity lacking in officially inspired art." This generation of the sixties also "accepted the values of Soviet society, although in an idealized way. For them socialism was inseparable from internationalism, democracy, and humanism, and they defended these values from the dead hand of bureaucracy." ${ }^{41}$ Much of this form of dissent in the 1960s had been fuelled by the "momentum of de-Stalinization" and was led by intellectuals, mainly literati. ${ }^{42}$ The sixties generation, then, worked to defend Ukrainian culture and language. For example, in 1963 the Conference on Culture and Language held at Kiev University "turned into an open demonstration against Russification." It was also at this time that Ukrainian students began making regular pilgrimages to the Shevchenko statue in Kiev 
to celebrate the renowned poet's works and "to criticize the regime's cultural policies." 43 Ivan Dziuba belonged to this milieu and his work reflects many of the attitudes of the generation of the sixties.

Ivan Dziuba was a Ukrainian writer who was incensed at the arrests of about two dozen protesters in a KGB crackdown on dissent in Ukraine in $1965 .^{44}$ The genesis of his book Internationalism or Russification? came when he submitted a draft of it in 1965 as an appendix to a statement he wrote on national policy addressed to the Ukrainian Central Committee. It has been suggested that Andrei Skoba, the Secretary of Ideological Affairs in the Ukrainian Central Committee, encouraged Dziuba to publish this appendix as a book. Once the book was written, it was distributed "among a few top-ranking Party officials on the level of regional secretaries." This edition soon disappeared and Dziuba's book was published as samizdat as well as abroad as tamizdat. $^{45}$

In his book, Dziuba attacks Soviet nationality policy from a decidedly Leninist perspective. He writes, "Marxism-Leninism defines a nation as an historically evolved community characterized by unity of territory, economic life, historic fate, language, and mental mould as revealed in its culture. In all of these aspects the Ukrainian nation today is not experiencing a 'flowering', as is officially proclaimed, but a crisis, and this must be admitted if one takes even a moderately honest look at actual reality." The "crisis" of the Ukrainian nation, Dziuba argues, has been created due to the loss of "territorial unity and sovereignty" through the mass resettlement of Ukrainians into other parts of the Soviet Union and due to the fact that Ukrainian culture was being treated as "second rate." The Ukrainian language, according to Dziuba, "has also been pushed into the background and is not really used in the cities of the Ukraine." Ultimately, Dziuba blames the Ukrainian nation's "crisis" on "the violation of the 
Leninist nationalities policy, from its replacement by Stalin's Great-Power policy and Khrushchev's pragmatism, all irreconcilable with scientific communism." ${ }^{46}$ Dziuba claims, then, that the Soviet regime had abandoned true Leninist principles with regard to nationality policy and that this has created a crisis for the Ukrainian nation.

Dziuba also argues that it was erroneous to declare that the nationality problem had been solved in 1917. Instead, he insists that even Lenin did not declare the problem to be solved in 1917. Indeed, Dziuba writes, Lenin claimed that the revolution was only the first step toward solving the nationality problem. Moreover, Dziuba argues that Lenin insisted on the importance of open discussion for finding proper ways to solve the nationality problem. Yet Stalin's crimes began the systematic violation of Leninist principles in nationality policies.

Dziuba is especially critical of the official policy of the assimilation of nations in the Soviet Union, which, as has been discussed throughout this study, was one of the more imperialistic aspects of Soviet nationality policy and which formed a key part of Brezhnev's Developed Socialism. Dziuba writes, "Among the overwhelming mass of the population the notion prevails that the next, perhaps even the immediate, task of communists is the creation of a nationless society, an 'amalgamation of nations', and that therefore national languages and cultures are something moribund, backward, second-rate and even reactionary, at any rate, something suspect and pitiable." He then asks what the source of this idea is. He points out that the concept of the assimilation of nations is officially presented as scientific communism, but Dziuba disagrees: "The idea of the assimilation of nations, the idea of a future nationless society is not an idea of scientific communism, but of that kind which Marx and Engels called 'barracks communism'. This is also the idea of revisionists, social-democrats of the Second International. Kautsky, in particular, made much of it." Dziuba argues that while Lenin before the revolution 
wrote about the assimilation of nations, after the revolution, "having taken up the practical task of nation-building, Lenin substantially shifted his emphasis and did not say one more word about the benefit of any kind of assimilation, but directed the whole force of the struggle against Russification, Great Russian chauvinism and Great-Power ideology, that is to say, in fact, against assimilation." Moreover, Dziuba cautions that such assimilationist policies in a state with an imperial past such as the Soviet Union, "would unfailingly bring about a whole series of deep injustices toward the nationalities of that state and the rebirth, in new forms, of the old imperialist relations within that state, and would greatly harm the cause of communism and freedom in the whole world. This is what Lenin opposed." ${ }^{\prime 47}$ Finally, Dziuba equates assimilation to colonialism: "assimilation (on the basis of a single national culture or in some other way except on the basis of universal culture) it is identical with colonialism (since it deprives other peoples in advance of the essential condition of equality - the right to an equal contribution to universal culture, and condemns them to cultural dependence with all its consequences for the psychological nature of individuals belonging to this nation and for their resulting status in society)." ${ }^{48}$ For Dziuba, then, Soviet assimilationist policies were simply a return to the Russian imperial past.

Dziuba is also critical of what he calls the rehabilitation of the tsarist Russian Empire. Associated with this rehabilitation of the past was the constant heralding of the Russian people as the carriers of internationalism and enlightenment to the non-Russian peoples. More specifically, Dziuba states that official pronouncements claim that it was not the Russian Empire but the Russian people who brought these "blessings" to the non-Russian peoples. Dziuba argues, however, that "this 'correction' is of the kind that would allow us to justify the conquest of India by saying that the English people is a great people and it will not do to offend it by 
reminding it of its colonies." This "correction", according to Dziuba, in part is what led the Soviet regime to begin rehabilitating the tsarist past during the Stalin period.

Dziuba argues further that early Bolshevik policies of korenizatsiia (Dziuba actually refers to Ukrainization) were correct and would have produced positive results. He notes that after the October Revolution, the Bolsheviks “stressed Russia’s historic guilt towards these peoples and regarded their action of decolonizing, among other things, as reparation for this historic guilt. This is a perfect ... parallel to the way in which Marx and Engels formulated the question of the historic debt of the English working class to Ireland."49 Here, Dziuba actually refers to korenizatsiia policies as an act of decolonization initiated from the center. According to Dziuba, Ukrainization included 12 main categories including promoting the "development of national consciousness and dignity" among the Ukrainian working class, encouraging the Russian population in Ukraine "to acquaint themselves with Ukrainian culture, history, and language", the Ukrainization of all Party and soviet activity, the Ukrainization of the economy and of cities, the "safeguarding of an essential minimum of economic self-government and initiative for the Ukraine", and other areas for promoting Ukrainization. Dziuba concludes that these policies are "just how it should have been formulated by the communists of the Ukrainian Soviet Republic, whose people had lived for 450 years under colonial oppression (Polish for over 150 years, Russian for about 300) and, having finally won their freedom, had to repossess themselves of their elementary rights." Had these policies been fully implemented, Dziuba claims, Ukraine "would undoubtedly have achieved immeasurably more" and it would have served as a "compelling example for all the young national states of Asia and Africa, and for all national liberation movements, of the fruitfulness of the Leninist approach to the national problem.",50 
Dziuba argues that the Ukrainization policies of the 1920s were replaced by a reinvigorated Russification of Ukraine in the 1930s. He writes that the Russification of Ukraine led to social stratification in Ukraine as well as the degrading of the Ukrainian language and of Ukrainian culture. For example, he writes, "Where 'the authorities' speak Russian, soon everybody will also be forced to start speaking Russian. The language of the "commanding elements' gradually triumphs over the whole environment ..." As a result, Russian became the language of "the 'higher', 'more educated' strata of society" while Ukrainian was relegated to the rural lower strata. Moreover, as Russification seeped into the smaller towns and into the countryside, Party officials and bureaucrats attempted to speak Russian and encouraged their subordinates to do likewise. This, Dziuba states, resulted in the development of "a language which is neither Ukrainian nor Russian but a hideous mixture, popularly called surzhyk; there is developing not a culture but a vulgar ersatz, a shoddy mass product with pretensions to 'the city style." "51 By the 1960s, Russification policies gave rise to Ukrainophobia, according to Dziuba, which only further degraded Ukrainian cultural life.

Ivan Dziuba, then, equated Soviet nationality policies since the 1930s as imperial in nature and he decried Ukraine's colonial status within the Soviet Union. But he criticized Soviet nationality policy from a Marxist-Leninist perspective, in effect warning the Soviet authorities that the Soviet Union of the 1960s was not necessarily what Marx or Lenin had envisioned in terms of nationality policy. While Dziuba was critical of Moscow, he stopped short of calling for Ukraine's independence; he merely wanted a return to Ukrainization policies of the 1920s. But he also compared Russian-Ukrainian relations to those between the English and the Irish. And his use of Marxist-Leninist theory to attack Soviet policies placed Dziuba in a line of 
Ukrainian Marxists dating to before the October Revolution to use Marxism as a weapon against Russian or Soviet imperialism.

Since at least 1911, Ukrainian Marxism was characterized by a strong anticolonialist current, which was revived by Dziuba's work in the mid 1960s. Before 1917, "Ukrainian leftist intellectuals combined Marxism with nationalism to theoretically justify national liberation." Moreover, like Ho Chi Minh, Mao and others, Ukrainian Marxists “'nationalized' Marxism much the way Lenin created a Russian national version of Marxism. But, unlike Lenin, Ukrainian Marxists, as representatives of a ruled nationality, regarded Bolshevism as a renewed Russian imperialism; an imposed local nationalized communism rather than a universal norm to emulate." By the 1920, "national communism" had become a dominant theme among Ukrainian left SDs and left SRs who were skeptical of the Bolsheviks as they regarded the Bolsheviks as new agents of Russian imperialism. Just as the Algerian Communist Party reflected the interests of French settlers in Algeria and thus did not advocate for Algerian independence, the Communist Party of Ukraine, formed in 1918 as a branch of the Bolshevik Party, was regarded as the party of Russian settler-colonists and therefore another extension of Russian imperialism. Ukrainian "anti-colonialist" communism survived through the 1920s, but died out in 1931 when two prominent "anti-colonialist” Ukrainian Marxists, Mykola Skrypnik and Mykola Khvlovyi, committed suicide when it became apparent that "under Stalin, revolutionary universalism, proletarian internationalism, and national revival were impossible."52 Thus, Ivan Dziuba revived the Ukrainian tradition of Marxist anti-colonial thought that dated to pre-revolutionary days.

Dzuiba's use of Marxism-Leninism also is analogous to the general wave of MarxistLeninist anticolonial thought that had permeated colonial peoples around the world through the $20^{\text {th }}$ century. Since the 1920 s, figures such as Ho Chi Minh in Vietnam, Kwame Nkrumah in 
Ghana and M.N. Roy in India had fused the anti-imperialist principles of Leninism with nationalism and became prominent leaders in their respective countries' independence movements.

Since his youth, Ho Chi Minh had been a Vietnamese nationalist opposed to French imperial rule. In the 1920s, Ho had been instrumental in forming the French Communist Party as he railed against the French Socialist Party's apparent refusal to address the colonial problem. He also spent considerable time in the Soviet Union where he studied at Stalin's School for the Toilers of the East. It was during his time in the Soviet Union that Ho began fusing his nationalist beliefs with Marxism-Leninism. He also became a member of the Comintern where he constantly reminded his fellow delegates to pay close attention to the colonial peoples of the East, often to little or no avail. ${ }^{53}$

Perhaps the best example of Ho's fusion of nationalism with Marxism-Leninism is "Report on the Draft Amended Constitution" in 1959. In this report, Ho writes, "the Russian October Revolution broke out and won glorious victory. The Union of Soviet Socialist Republics was founded. The colonial system of imperialism began to collapse." He adds that the "oppressed peoples of the world saw that only by relying on socialist revolution and following the line of the working class was it possible to overthrow the imperialists, win back complete national independence and realize genuine equality among the nations." Later, Ho emphasizes that after Dien Bien Phu, the Vietnamese people realized a great victory against imperialism and that this victory "proves that even a small and weak nation can most certainly defeat the imperialist aggressors, if it is closely united under the leadership of the working class and its Party and correctly follows the Marxist-Leninist line.” ${ }^{, 54}$ Thus Ho, like Dziuba, championed Marxism-Leninism as a liberating force that enables the establishment of the 
equality of nations. The key difference, however, is that Dziuba used his interpretation of Marxism-Leninism to attack what he considered to be Soviet imperialism, whereas Ho looked to the USSR as the leader in the global anti-imperial struggle.

Ho did more than other colonial Marxists to fuse nationalism with Marxism-Leninism. Other prominent leaders in decolonization movements around the globe were either influenced by Marxism-Leninism and the Soviet model of modernization (such as Kwame Nkrumah in Ghana), or actually belonged to Communist parties in their respective countries (such as M.N. Roy in India). Most often, leaders such as Nkrumah attacked imperialism on an economic basis, borrowing heavily from Lenin's writings on imperialism. ${ }^{55}$ Communism also played a role in the decolonization process in French West Africa after World War II just as the French government was focusing on rooting out Communism both at home and in its colonies. ${ }^{56}$ Thus, Ivan Dziuba in the 1960s was part of a global trend of employing Marxism-Leninism as a weapon against imperialism. The great irony, of course, is that Communists in the Third World looked to Moscow as a liberator whereas Dziuba and other like-minded non-Russian peoples in the USSR saw Moscow as their imperial oppressor. And, just as the French saw Communism as a threat to their empire, Moscow saw what it termed "Western imperialism" as the threat to its empire.

\section{Independence Movements in Ukraine}

Although Dziuba did not demand Ukrainian independence, a number of organizations and individuals did advocate for independence in the 1960s and 1970s. The vast majority of these were centered in western Ukraine, which had been annexed by the Soviet Union in 1940. Comprising only 16 percent of Ukraine's population, western Ukraine was home to 10 of 17 
underground organizations uncovered in the 1960s and 1970s. ${ }^{57}$ The underground nationalist organizations that existed in western Ukraine during the Brezhnev period continued the fight against Soviet rule which had started during World War II and was led by the Organization of Ukrainian Nationalists (OUN). Indeed, one such group uncovered by the KGB in the 1960s called itself the OUN-North, presumably claiming itself to be a successor to the OUN of the 1940s and 1950s.

The organizations found in western Ukraine were small yet very active and they were subjected to numerous arrests and constant KGB harassment. Most activities involved publishing "programs" calling for the peaceful secession of Ukraine from the USSR in accordance with Article 17 of the USSR Constitution which provided for the secession of Union Republics. The Union of Workers and Peasants was one such organization that sought Ukrainian secession under Article $17 .^{58}$

Most nationalist activities in Ukraine or involving Ukrainians outside of the republic as reported by Chronicle of Current Events concerned personal acts of defiance rather than mass demonstrations such as those that took place in Lithuania. A common form of protest took the form of hunger strikes among Ukrainian prisoners in the Mordovian prison camps. For example, in 1970-71, Dmitry Kvetsko, who had been sentenced to 15 years for participating in the Ukrainian National Front, staged a hunger strike as did Roman Semenyuk who was serving a 25 year sentence for his membership in the OUN and Iosif Tereza, who had been sentenced to eight years in the camps for possessing Ukrainian nationalist propaganda. ${ }^{59}$ Additionally, in 1970 , Ukrainian national dissidents began publishing in samizdat the journal Ukrainian Herald, whose "aim is to inform the public about violations of human rights in the Ukraine, [and] about cases of chauvinism and Ukrainophobia."60 
However, as in Lithuania but perhaps on not as grand a scale, more overt acts of nationalism occurred in Ukraine in the 1960s and 1970s. Alexeyeva reports that on November 5, 1968, Vasily Makukha, a Ukrainian teacher from Dnepropetrovsk who had been a political prisoner under Stalin, set himself on fire and ran down a main street in Kiev shouting "Long live a free Ukraine!" He died two hours later. ${ }^{61}$ There were also more organized activities. Issue 26 of A Chronicle of Current Events, published in July 1972, reports that for several years, May 21 - Shevchenko Day - had been observed "by laying wreaths at the Shevchenko memorial in Kiev, and by singing and dancing around the statue." However, in recent years, the authorities had tried to coopt Shevchenko Day in order to give it a more "official character." These attempts to rein in Shevchenko Day involved police seizing "persons trying to approach the Shevchenko memorial, those trying to sing Ukrainian songs, and even those dressed in Ukrainian embroidered shirts or wearing Shevchenko badges on their chests.",62

In January, 1972, Jaroslav Dobosch, a resident of Belgium, was arrested by the KGB and accused of coming to the USSR "to carry out an assignment for the foreign anti-Soviet center of the Bandera-ites of the OUN ... and that in connection with his case criminal proceedings had been started against I.O. Svitlichny, V.M. Chornovil, Ye. O. Sverstyuk and others.”,63 On June 5, Dobosch held a press conference which was televised on Ukrainian television in which he stated "In 1967 I joined a nationalist organization - the Ukrainian Youth Association (SUM). This organization consists of young people who ... are fighting ... for the creation of an independent Ukraine ... In fact this organization is directed by the OUN [Organization of Ukrainian Nationalists]."64

Some Ukrainian dissidents also referred to Ukraine's "colonial status" and heralded the possibility of decolonization in the Soviet Union. Valentyn Moroz, a prominent member of the 
Ukrainian Helsinki Watch Group, delivered a speech to the National Press Club in Washington, DC in 1979 in which he stated, "The tragedy of the Ukraine lies in the fact that the world's attention is focused on the struggle of Blacks for the decolonization of Africa." Instead, Moroz stated that "the arena of decolonization should shift to Eastern Europe and the USSR where we have dozens of subjugated nations as well as the largest colony in the world - Ukraine - a nation of 50 million people." 65

National dissent in Ukraine, then, comprised both efforts to call for an end to Russification but to remain within the USSR as advocated by Dziuba and calls for outright independence for Ukraine, which were mostly concentrated in western Ukraine. And at least some Ukrainians, such as Valentyn Moroz, saw Ukraine as a colony within the Soviet Empire and directed their activities toward the decolonization of Ukraine.

\section{Dissent in Moldavia and Armenia}

National dissent in Moldavia and Armenia also reveals the presence of a decolonization movement in parts of the Soviet Union during the Brezhnev period. As in the Baltic republics and in Ukraine, dissent in Moldavia and Armenia resisted Russification and in some cases called for secession from the Soviet Union. The key difference, however, is that incidents of dissent in these two republics appear to have been less frequent, owing probably to the fact that these were the two smallest Union Republics and to the possibility that available sources are more focused on dissent in Ukraine and the Baltic.

Moldavia was a special case in the Soviet Union for two main reasons: first, in the way that it was incorporated into the Soviet Union. Like the Baltic republics and western Ukraine, the Soviet Union annexed Moldavia from Romania in 1940. But unlike the Baltic republics, the 
Soviet annexation of Moldavia appeared to be less traumatic as Moldavia was not an independent state before 1940. Second, the Moldovans were a new nation, one created by the Soviets. In language especially, the Moldovans were indistinguishable from Romanians. Thus, as will be discussed, Moldovan nationalist dissent focused its efforts on reunification with Romania.

The region of Bessarabia, which would come to be known as Moldavia (and, after 1991, Moldova), had since the $16^{\text {th }}$ century formed part of three different states: the Ottoman Empire, the Russian Empire, and, after 1919, the state of Romania. Linguistically and culturally, most regarded the Moldovans as simply "an eastern offshoot of the Romanians" whose dialect was virtually the same as Romanian but used more words borrowed from neighboring Slavic languages. ${ }^{66}$ However, beginning in the 1920s, the Soviets launched a concerted effort to create a Moldovan nation with an identity separate from that of Romanian. Key to this effort was the formation of the Moldovan Autonomous Soviet Socialist Republic (MASSR) on the western end of Ukraine in 1924. In the years that followed, "Moldovan histories, textbooks, grammars, newspapers, and other publications were hailed by the Soviet authorities as the first fruits of a Moldovan nation in the making." ${ }^{\text {.67 }}$ The Soviets created the MASSR and invented a new Moldovan nation for two reasons, both of which involved foreign policy concerns. First, "the new republic facilitated the penetration of Soviet propaganda into the kingdom of Romania, thus paving the way for a Romanian socialist revolution." Second, it made sure that "the Bessarabian question remained a topical issue in international politics and a thorn in the side of Romanian diplomats at the League of Nations." Concerns related to korenizatsiia policies in the 1920s also facilitated a process of "moldovanization" similar to Ukrainization efforts in Ukraine. ${ }^{68}$ Moldovanization policies came to an abrupt end in 1930. 
Unlike in the Baltic republics where the Soviets had to coopt existing national governments and then Sovietize what had been independent states before 1940, in the case of Moldavia, the Soviets simply annexed it in 1940 from Romania under the terms of the Secret Protocols of the Nazi-Soviet Non-Aggression Pact. On June 26, 1940, Moscow sent an ultimatum to the Romanian government demanding Bessarabia under the pretext that Northern Bukovina (which formed part of Bessarabia) "would be taken as recompense for the hardship experienced by the Bessarabians since 1918." Surprisingly, the Moldovans were not mentioned at all in the ultimatum. Instead, Moscow claimed that the population of Bessarabia was "for the most part Ukrainian" and thus linked to Ukraine "by shared historical destiny and by shared language and national composition." Thus on August 2, 1940 (the same week as the Baltic republics), the Moldavian Soviet Socialist Republic came into existence. After border changes and the effects of World War II, the MSSR emerged with a population that was 68.8 percent Moldovan. ${ }^{69}$

Like the Baltic republics, the new Moldavian SSR was Sovietized after the return of Soviet rule in 1944. This involved rapid collectivization of agriculture and the deportation of those Moldovans who were classed as "collaborators" either with the German occupiers or with the pre-war Romanian state. Also, just as Ukrainians had been encouraged (or forced) to emigrate to other regions of the Soviet Union, up to 40,000 Moldovans "volunteered" to emigrate to eastern regions of the Soviet Union in the 1950s. The Moldavian Communist Party also had a membership that was overwhelmingly Ukrainian or Russian, which reflects further the imperial nature of Soviet rule in Moldavia and which was also seen in the Baltic republics. By 1989, only 47.8 percent of Moldavian Communist Party members were Moldovan, while 20.7 percent were Ukrainian and 22.2 percent were Russian. ${ }^{70}$ Moreover, linguistically, by 1989, 
"Moldovans were the third most russified nationality in the Soviet Union; only in Ukraine and Belarus did a higher proportion of the titular nationality report Russian as their native language."71

After World War II, a gradual Romanization of the Moldovan intelligentsia took place. Unlike before the war when Moscow was trying to cultivate a Moldovan nationality in part to spread revolution to Romania, after the war, with the establishment of a socialist Romania, Soviet policy shifted to "simply stating that Moldovans and Romanians were different, without really trying to make them so." Thus, by the 1960s, the only real difference between the Moldovan and Romanian languages was their alphabets - Moldovan used a Cyrillic alphabet. Meanwhile, during and after Nicolae Ceausescu's rise to power in Romania, Romanian leaders and intellectuals began denouncing the Soviet annexation of Bessarabia as Ceausescu embarked on a path that was more independent of Moscow at least in terms of foreign policy. ${ }^{72}$

It was in this context of the developing Romanization of Moldovan intellectuals and of Ceausescu's intransience in Romania that incidents of Moldovan dissent were reported in Chronicle of Current Events. On June 22, 1976, Georg Gimpu, a Moldovan prisoner in Perm Camp No. 35, wrote a letter to the Chairman of the Presidium of the USSR Supreme Soviet. In this letter, Gimpu did not mention the Moldovan nationality; instead he referred to himself and his fellow Moldovans as Romanians. Gimpu wrote, “As a Romanian from Bessarabia and as a political prisoner, I demand that the Presidium of the USSR Supreme Soviet should resolve in the near future to return Bessarabia to Romania, thus giving the Romanian people the opportunity to unite, all the more so as the same socio-political system exists in both Bessarabia and Romania." He then announced that if his demand is not met, he would go on hunger stroke beginning on June 28, the anniversary of the Soviet annexation of Bessarabia in $1940 .{ }^{73}$ Along 
similar lines, in 1967 Yakov Vladimirovich Odobescu, a bee keeper from Moldova, was arrested for writing a letter to Moldavia's First Secretary Bodiul and to other Moldavian Party officials demanding that Moldavia be protected from Russification and that it be re-united with Romania. He also allegedly circulated leaflets stating, "Moldavia for the Moldavians, for the Russians Russia". For his efforts, Odobescu was sentenced to a seven year term in strict-regime corrective-labor camps by the Moldavian Supreme Court. ${ }^{74}$

Thus nationalist dissent in Moldavia opposed Russification, which is similar to dissent in the Baltic republics and in Ukraine, but there were no demands for Moldovan independence. Rather, dissent in Moldavia sought reunification with Romania. This indicates that in the 1960s and 1970s, Soviet efforts to forge a new Moldovan nation had not really succeeded; most Moldovans seemed to share a Romanian identity. However, Moldovan national consciousness would grow in the 1980s during glasnost' and perestroika. $^{75}$

Whereas the Baltic republics, Moldavia, and western Ukraine were added to the Soviet Union through annexation some twenty years after the formation of the USSR, Armenia was one of the original republics of the Soviet Union. Yet, Armenia was a complicated matter. The Armenians were a diaspora nation - a large percentage of Armenians lived outside of the Armenian SSR either in other parts of the Soviet Union or in Turkey or in parts of the Middle East. As a result of this, Armenian nationalist dissent often demanded Armenian independence along with a rearrangement of Armenia's borders. Mount Ararat, a powerful symbol of Armenian national identity, is actually in Turkey, and Armenian nationalists always wanted this landmark to be located in Armenia. Indeed, the state seal of the Armenian SSR had Mt. Ararat placed prominently in the center ${ }^{76}$, though Moscow never intended to annex the region around Ararat from Turkey. Moreover, the Armenians during World War I were caught between Russia 
and the Ottoman Empire and they were forced to choose sides. The Dashnaks, an Armenian nationalist group formed in 1890 , initially decided to cast their lot with the Turks, but then switched to support Russia as they believed the Allies had a better chance of winning the war. ${ }^{77}$ Finally, Armenian nationalist dissent not only opposed Russification but they also fought against the Azerbaijanis, particularly over the status of Nagorno-Karabakh, a region with a large Armenian population but located within the Azerbaijani SSR.

Several underground organizations appeared in Armenia in the 1960s. The most independent-minded of these organizations was the National Unification Party (also referred to as the National United Party) which formed in 1966. The NUP published a newspaper, Paros (The Beacon), as well as a journal, In the Name of the Homeland. NUP members called for the formation of an independent Armenia and distributed leaflets bearing the title "We Can No Longer Keep Silent."78

In 1968, Paruyr Ayrikyan became the head of the NUP and he was arrested in 1969. In 1974, while still serving his sentence in a prison camp, Ayrikyan along with other NUP members reformulated the party's program. The new program rejected the anti-Marxist stance of the previous program as well as the former program's support for extremist actions. The new NUP program's emphasis, however, was on Armenian independence. The NUP called for the Armenian SSR to exercise its right to secession as provided by the USSR Constitution and to accomplish this through an all-Armenian referendum in which all Armenians, even those living outside of Armenia, could vote. The NUP program also suggested that such a referendum be conducted under UN supervision. ${ }^{79}$

Between 1968 and 1975, 18 members of the NUP were arrested and tried, usually on the charge of anti-Soviet agitation. ${ }^{80}$ Among those tried, was Ayrikyan, who had been paroled from 
the camps after his initial arrest and prosecution in 1969 and then arrested again in 1974 and sentenced to two years for "breaking the rules of surveillance" (he had been under KGB surveillance since his release). At his 1974 trial, Ayrikyan was accused of writing letters to the UN and to the Armenian Supreme Soviet as well as the distribution of leaflets. The prosecutor also charged Ayrikyan with writing letters to his parents during his first prison term in which he stated that the $50^{\text {th }}$ anniversary of the formation of the Armenian SSR was a "tragic day" for him as it was on that day that Armenia "had ceased to exist."

At his trial, Ayrikyan spoke in his own defense. In his speech, Ayrikyan commented that he still supported a free Armenia and that he still wished for Armenia to secede from the USSR based on the provisions of the USSR Constitution. He also told the court, "Up to now there has been no country in which they try people for patriotism" but "until there is an independent Armenia, my place will be in a prison cell." He then accused the Soviet authorities of being weak, for "Only the very weak fear words, and answer words with brute force." Ayrikyan concluded his speech by declaring, "Long live a free Armenia! My goal is not class struggle. I am interested only in achieving an independent Armenia." With that, Ayrikyan was convicted and sentenced to seven years in a strict-regime labor camp with another three years of exile. ${ }^{81}$ In December 1976, a group of seven political prisoners, none of whom bore Armenian names, wrote a letter addressed to the NUP. In this letter, they wrote that the desire of Armenian independence in accordance with the secession provision of the USSR Constitution aroused their sympathy. They continued, "The desire of every people to have its own home, not contented with the communal flat of Soviet togetherness, is completely natural." They then stated that the friendship of Soviet peoples is only possible "between worthy partners." Then the authors of the letter attacked the imperial nature of the Soviet Union: "Only the de-imperialization of the USSR 
can return to every people the inalienable feeling of its own worth, will free it from the constant feeling of its incompleteness; this process will cleanse the psychology of a certain part of the Russian people from imperial complexes, which are strangely combined with a national inferiority complex." The seven authors of this letter, then, characterized Soviet nationality policy as imperialistic. They claimed that decolonization would be beneficial to the peoples of the Soviet Union.

Decolonization would not simply be beneficial to the non-Russian peoples, however. The letter also argued that decolonization would also help the Russian people. They write, "We think the opinion is mistaken that Russia, having lost the Ukraine, the Baltic states, the Caucasus or Central Asia, will be a loser - this mistaken opinion is just as insulting to Russians as it is to Ukrainians, Lithuanians, and Armenians." 82 This statement is the most direct reference made to decolonization in the Soviet Union. It is evidence that such a process was developing in the USSR during the Brezhnev period. Interestingly, this statement is also relevant in the $21^{\text {st }}$ century. Vladimir Putin's annexation of Crimea in 2014 and the subsequent separatist conflict in eastern Ukraine seems to prove this letter wrong - Putin, at the very least, appears to believe that Russia was indeed "a loser" when it "lost" Ukraine after the dissolution of the Soviet Union in 1991.

\section{The Brezhnev Leadership's Response to Dissent}

Clearly, as this chapter has shown, nationalist dissent manifested itself throughout the Soviet Union during the 1960s and 1970s. Much of this nationalist dissent formed part of a broader decolonization process developing during the Brezhnev period as evidenced by the incidents and statements from the Baltic republics, Ukraine, Moldavia and Armenia. This 
section will examine how the Brezhnev leadership dealt with this dissent and will argue that due largely to ideological reasons, the Brezhnev leadership failed to recognize nationalist dissent as a decolonization process. Instead, the Brezhnev leadership simply thought of this dissent as nationalism, often instigated by outside Western forces.

In 1983, the CIA estimated that there were nearly four times as many reports of civil unrest in the Soviet Union in 1972-1982 than there were in 1953-1963, and this number appeared to be growing after 1979. At least 280 incidents of civil unrest were reported by the CIA from 1970 to 1982 . Most incidents of civil unrest involved simple protests or small-scale work stoppages in response to economic difficulties, especially after the crop failure of 1975 . But there was a sizeable nationalist dimension to these cases of civil unrest. The CIA reported that “Two causes [of protest] - expressions of ethnic nationalism and the pursuit of exit visas account for 60 percent of reported demonstrations ... Nationalism has figured most prominently in demonstrations in Estonia and to a slightly lesser degree in Lithuania and Georgia." 83 In the same report, the CIA noted that riots had occurred in the Baltic republics and in Central Asia, with the eight known riots occurring in the Baltic republics serving as the "clearest cases of ethnic nationalism inspiring major civil disturbances - or fueling them if the outbreaks result from other causes such as food shortages." Moreover, there were attempts to assassinate four republic First Secretaries in the 1970s: P. Grishkavichyus in Lithuania in 1976, K. G. Vaino in Estonia in 1979 (three attempts were made on his life), A.E. Voss in Latvia in 1977 and 1979, and against E. Shevardnadze in Georgia in 1973 and $1976 .^{84}$

The Brezhnev leadership's response to what the CIA identified as a rising tide of dissent was multifaceted, but of course refused to admit that the nationalist dissent was of an anticolonial nature or that its nationality policy was somehow flawed. The Brezhnev leadership's response 
involved repression, often by arresting dissidents and/or harassing members of dissident groups, a continuing focus on modernization to equalize living and education standards among the Soviet nationalities, blaming nationalist dissent on anti-Soviet elements who were either inside the USSR or were in cahoots with foreign (Western) agents, shortcomings in the work of Party or KGB officials, calling for greater educational/ideological work among the Soviet population, and continued reliance through the 1970s on promoting the tenets of Developed Socialism.

Repression was the strategy most often used to disrupt the activities of nationalist dissidents and has been written about elsewhere. ${ }^{85}$ This section will instead focus on the other responses by the Brezhnev leadership.

Aside from repression, the Brezhnev leadership's most common response to dissent was simply blaming outside forces for agitating the Soviet population. At a meeting between KGB and East German Stasi officials in East Berlin in November 1969, the Soviets and the East Germans discussed the issue of ideological subversion in the Soviet Union and in East German and strategies to deal with such subversion. ${ }^{86}$ At this meeting, KGB deputy Zvigun thanked his East German counterpart for the Stasi's efforts to break up nationalist and other anti-Soviet activities originating from West Germany. Zvigun then stated that at a Central Committee Plenum in April 1968, Brezhnev emphasized the importance of ideological subversion in the Soviet Union. Zvigun added that "the issue of ideological subversion represents the most important form of imperialism's fight against the Soviet Union and the other socialist states. It is a part of imperialism's global strategy." Moreover, Zvigun blamed Western intelligence agencies for fomenting ideological subversion especially in Czechoslovakia. Inside the USSR, Zvigun also assigned blame to Western intelligence services as well as Western radio broadcasts and radio broadcasts originating in China. 
Zvigun also blamed émigré communities for fomenting and supporting anti-Soviet activity among the non-Russian peoples of the USSR. He informed his East German counterpart that "émigré organizations of Ukrainian, Latvian, Estonian, Lithuanian and Armenian activists are very active. They have recruited their cadres especially from traitors who collaborated during the war with the fascists and moved with them to the West." These émigré organizations, according to Zvigun, were working with Western intelligence agencies to broadcast "the vilest slander in Russian and the different languages of the Soviet peoples." Note that Zvigun singled out Ukrainian, Latvian, Estonian, Lithuanian and Armenian émigré circles as the most active. This further demonstrates that nationalist activity was strongest in these republics.

Zvigun noted that while "There is strong unity between the party and the people" in the USSR, a nationalist problem did exist and that Moscow was working to defeat it. He stated, "We are devoting major attention to nationalist organizations. The focus of ideological subversion is nationalism, the exploitation of national feelings, and their utilization by all those diverse nationalist émigré organizations to undermine the Soviet Union's policies towards ethnicities." Zvigun, then, highlighted to his East German counterparts that nationalism in the Soviet Union was a problem that had to be dealt with, although it did not pose any real threat to the Soviet regime itself. Moreover, Zvigun attributed the nationalist problem not to any potential defects in Soviet nationality policy, but to ideological subversion and the influence of foreign elements.

The KGB, however, must have recognized that nationalist dissent was a growing problem across the USSR. Zvigun told his East German counterparts that the KGB formed a new $5^{\text {th }}$ Directorate "for the fight against ideological subversion." The new $5^{\text {th }}$ Directorate had already established a network of agents to keep an eye on the 10,000 tourists from capitalist countries that were staying in Moscow on a daily basis. Zvigun also noted that "We increasingly organize 
the work against domestic hostile centers. It is important here for the KGB headquarters to use the potential of KGB facilities in the Soviet republics, in particular for infiltration of these hostile centers." Zvigun also hinted that the KGB was stepping up its efforts to overcome the "lagging behind of previous years."

Ten years later in 1979, M.A. Yuzbashyan, the Chairman of the Armenian KGB, also blamed "ideological subversion" and foreign influences on nationalist activities in Armenia. ${ }^{87}$ Yuzbashyan claimed that "the most aggressive forces of imperialism" led by the United States and also including the leadership of the People's Republic of Cambodia (due to its "aggression" against Vietnam earlier in 1979) constituted "an attempt by our enemies to create a united antiCommunist front." He added that "One would like to especially emphasize the fact that the enemy ... has adjusted its tactics and focused on conducting ideological subversion which has as its goal 'exploding' socialism from within.” Such ideological subversion, Yuzbashyan maintained, was the result of the influence from "hostile Western propaganda" and thus it was the job of the KGB to protect "Soviet society from the overtures of the reactionary imperialist forces ..." Ultimately, Yuzbashyan claimed, the bombings of the Moscow Metro and at two grocery stores in Moscow in November 1977 by Armenian nationalists were the result of the ideological subversion carried out by hostile foreign elements. In addition to the 1977 Moscow bombings, Yuzbashyan stated that "Over the last 12 years, the Armenian KGB has uncovered and liquidated more than 20 illegal anti-Soviet nationalist groups created under the influence of hostile Western propaganda." Thus for Yuzbashyan, and for Zvigun ten years earlier, nationalism in the USSR was due to ideological subversion as the result of hostile foreign influences. 
But in addition to Western influence, Yuzbashyan also identified Armenian émigré organizations, which, according to Yuzbashyan, "represent a special concern for us." He continued, "The enemy, primarily the United States, actively works with the foreign Armenian colonies - they use all means to encourage persons of Armenian nationality to move and establish permanent residency in their country. Today already 600,000 Armenians reside in the United States." Yuzbashyan claimed that the United States had plans to increase the Armenian population there to one million and that the Dashnaks were the "best organized force in the foreign Armenian colonies." He also explained that American efforts to encourage the Armenian diaspora prompted the CPSU Central Committee to pass a resolution on December 27, 1978 to strengthen work among Armenians residing outside of the USSR. Ultimately, Yuzbashyan attributed nationalist activity in Armenia and Dashnak propaganda originating outside of the USSR to ideological subversion. Therefore, it was the task of the Armenian KGB to infiltrate and disrupt nationalist activities within the republic and to ensure that only "well-educated" Communists were working for the Armenian KGB as "only politically well-prepared Communist members of the security organs can carry out the demanding tasks of ensuring state security ..." Not only must such ideological subversion be countered, but continued ideological work among Party and security personnel was required as well in Yuzbashyan's assessment of the situation in Armenia.

Nationalist activity in Ukraine was also blamed on ideological subversion and on the influence of Ukrainian émigrés abroad. A CPSU Central Committee document from 1979 instructed the USSR Foreign Ministry to provide guidance to Soviet embassies in countries with large Ukrainian émigré communities - especially the United States, Canada, England, France, 
and Australia - on measures to "strengthen the work to counteract the activities of bourgeoisnationalist organizations." 88

Declassified CIA documents reveal that the United States was involved in encouraging dissent at least in Ukraine since the 1950s. In 1953, the CIA began supporting QRDYNAMIC, an operation that published "a Ukrainian-language journal, books and pamphlets, and other forms of printed and recorded materials for distribution into the Soviet Ukraine and other Eastern Bloc countries." The primary purpose of QRDYNAMIC was "to exploit and increase nationalist and other anti-Soviet dissident tendencies in the Soviet Ukraine.” Moreover, QRDYNAMIC activities also involved the publication of a pamphlet on Soviet nationality issues for distribution to Third World countries in order to show that "the USSR is, in fact, a colonial empire where the non-Russian nations find themselves in a subjugated role." The CIA claimed many successes for QRDYNAMIC including provoking attacks in the Soviet press against writings published under the auspices of the QRDYNAMIC operation. ${ }^{89}$

Finally, there were international and ideological components to the Soviet response to dissent of all forms in the USSR. On the international front, the Brezhnev leadership was concerned about the Soviet Union's image, especially after the signing of the Helsinki Accords in 1975. They were also concerned about maintaining unity within the global Communist movement and with the ongoing Cold War confrontation with the West. The CIA reported in 1977 that Moscow had been placing "pressure on the Eurocommunists to cease their 'carping' about human rights violations in bloc countries" and that Moscow was growing increasingly upset with American "interference" in the internal affairs of the Soviet Union. The Soviets even threatened the West European Communist parties with a reduction in Soviet funding and "the 
threat of compromising some West European parties by revealing details of their past collaboration with Moscow."90

Moscow also pursued more concrete measures to try to enhance its global image. Christian Peterson argues that in 1977 and 1978 during preparations for and meetings at the Belgrade Conference, the Brezhnev leadership decided to allow one dissident to go abroad for needed medical treatment and they "made a conscious decision not to put well-known Helsinki monitors ... on trial until this conference ended." He adds that the number of dissident arrests made in 1977 were the lowest since $1965 .{ }^{91}$

Along with international concerns, the Brezhnev leadership also took on an ideological response to dissent. The CIA reported in 1977 that "the Soviet approach to issues of ideology and social control has been increasingly conservative." Moreover, the CIA stated that Mikhail Suslov and other high-ranking members of the Brezhnev leadership favored "a harder ideological line at home." 92 By 1977, such a "harder ideological line" would have meant further reliance on the principles of Developed Socialism. Related to this issue is the adoption of the new USSR Constitution in 1977, which will be examined in depth in the next chapter. Peterson argues that the new USSR Constitution was ratified in 1977 due largely to international and domestic pressures placed on the Brezhnev leadership by the Helsinki Accords. He writes, "To show the Soviet Union's commitment to the 'Helsinki process', the new constitution defined the nation's approach to foreign relations (Article 29) in terms of a truncated version of the Final Act's ten principles regulating relations between signatories." And to detract dissidents from using the USSR Constitution to attack the actions of bureaucrats, "Article 59 indicated the exercise of rights and freedoms 'is inseparable from the performance of ... duties and obligations' to the 
state as defined by the CPSU." $" 93$ Peterson argues, then, that the new USSR Constitution in part was ratified in response to dissent in the Soviet Union.

As the next chapter will demonstrate, the 1977 USSR Constitution was also the culmination of the Brezhnev leadership's doctrine of Developed Socialism. The provisions in the new federal constitution and in the new Union Republic constitutions ratified in 1978 provided for a greater concentration of power in Moscow at the expense of the republics. Thus, the ideological conservatism noted by the May 1977 CIA report was likely a reference to the increasing reliance upon the tenets of Developed Socialism and its emphasis on greater unity at the expense of the political rights of the Union Republics and its continued emphasis on more Russification.

If the new 1977 USSR Constitution was ratified in part due to the pressures of dissent in the Soviet Union, an analogous development took place in the French Empire in 1958. On September 28, 1958 a referendum was held in France and in its colonial possessions to adopt a new constitution and to legitimize de Gaulle's return to power. However, the "immediate cause for the referendum was the crisis of French rule in Algeria and the inability of the Fourth Republic to deal with the conflicting demands of Algerian nationalists and colonial interests."94 The new constitution provided for greater autonomy for France's overseas colonies, but it stopped short of independence. However, pressure from African leaders forced the de Gaulle government to insert a clause in the proposed constitution to provide for independence, though the de Gaulle government had no intention of allowing this to happen. Thus, a vote against the new French constitution would have meant a vote in favor of independence for the colonies. ${ }^{95}$ Through the intervention of the French metropole in parts of West Africa such as Guinea and 
Niger, the "no" vote failed, and when independence did come to those colonies, it came on terms more favorable to France.

Thus the pressures created by a developing decolonization process in part caused France to draft a new constitution in which greater autonomy was given to the colonies, with independence coming to many parts of the French Empire in the 1960s through both violent and peaceful means. But in the Soviet Union, the opposite occurred. As the decolonization process developed in the USSR in the 1970s, the Brezhnev leadership responded with increased reliance on the tenets of Developed Socialism and more propaganda heralding the unity and internationalization of the Soviet peoples, led by their "elder Russian brother." As the next chapter will show, this culminated in the new 1977 USSR Constitution, which, unlike the 1958 French Constitution, called for less autonomy for the Soviet periphery.

\section{Conclusion}

Nationalist dissent in the Soviet Union in the 1960s and 1970s reveals that a decolonization process had been developing during the Brezhnev period. Nationalist dissent in this period consisted of moderate opposition to Soviet policies that promoted the Russian language and culture at the expense of non-Russian languages and cultures. Moderate dissent did not demand independence from the Soviet Union but instead wanted to reform Soviet policies to make them more consistent with the dissidents' interpretation of Leninist nationality policies, as was the case with Ivan Dziuba. This Marxist-Leninist opposition had long historical roots in the Soviet Union, particularly in Ukraine, and it fused nationalism with MarxismLeninism in ways similar to prominent decolonization leaders globally such as Ho Chi Minh. 
Radical nationalist dissent, however, did demand independence from the Soviet Union. Underground guerilla movements such as the Forest Brothers in the Baltic republics actively fought against Soviet forces in the years following World War II. While guerilla movements had been defeated by 1953, independence movements re-emerged in the 1960s that continued into the 1980s. Although the renewal of independence movements did not bring the return of guerilla warfare against Soviet forces, there were acts of mass protest such as those in Lithuania in the 1970s. All nationalist dissent movements remained underground during the Brezhnev period with occasional public outbursts, but they would emerge above-ground in the late 1980s and early 1990s as a result of Gorbachev's reforms, particularly in the Baltic republics.

The Brezhnev leadership did not consider the developing decolonization process to be a major concern. While episodes of moderate and radical nationalist opposition did take place, they did not involve large segments of the non-Russian population and therefore did not pose an immediate threat to the Soviet regime. In March 1976, Iurii Andropov reported to the CPSU Central Committee that the number of people distributing anti-Soviet propaganda fell in 1975 , but the volume of propaganda had increased over the previous year due to better access to copying machines. But only 33, or 2.5 percent, of those arrested for distributing anti-Soviet propaganda had prepared documents of a nationalistic nature. ${ }^{96}$ The Brezhnev leadership's strategy for dealing with nationalist dissent, then, focused primarily on repression but also on continued reliance on the tenets of Developed Socialism and its emphasis on promoting the greater unity of the Soviet Union. This culminated with the ratification of the new 1977 USSR Constitution and new Union-Republic Constitutions in 1978 that concentrated more power at the center at the expense of the Union Republics. 


\section{CHAPTER FIVE}

\section{ALL-UNION AND REPUBLIC CONSTITUTIONS}

After several years of public discussion dating to the Khrushchev era, the Soviet Union in 1977 ratified a new constitution, often referred to as the Brezhnev Constitution. This document is the crowning achievement of the Brezhnev leadership's economic and ideological policies as it enshrined into the fundamental law of the Soviet Union the basic principles of Developed Socialism. The stated purpose for drafting a new constitution was in essence to recognize that the Soviet Union had undergone tremendous change since the ratification of the Stalin Constitution in 1936. The Brezhnev leadership argued that the Soviet Union had successfully completed the building of socialism by the 1970s and now had entered the stage of Developed Socialism, thus preparing the country for the next stage of history - the building of communism. As such, the new 1977 Constitution in theory reflected this change and therefore focused primarily on updating the basis of the USSR's economic system in order to recognize officially the coming of Developed Socialism. But in doing so, the new 1977 USSR Constitution also led to the further consolidation of the Soviet Empire by tightening centralized authority in a number of ways. This chapter will show that the Brezhnev leadership had ideas for consolidating the empire even more, but was forced to retreat. Despite some minor setbacks, however, the 1977 USSR Constitution did result in at least a de jure tightening of centralized authority in the Soviet Empire even if this did not necessarily translate to a real consolidation of power on the ground.

This chapter will begin with a summary of the relevant sections of the 1936 USSR

Constitution $^{1}$ in order to provide a basic understanding of the Soviet Union's constitutional status prior to the ratification of the new document. Next, this chapter will review the Brezhnev 
leadership's reasoning for drafting a new constitution based on public speeches, articles in the Soviet press, and speeches delivered at the May 1977 CPSU Central Committee Plenum. This will provide insight both into the regime's thought process as well as into the methods used to sell the idea of a new constitution to the Soviet public. This chapter will then discuss the May 1977 CPSU Central Committee Plenum during which members of the Central Committee reviewed one of the final drafts of the new constitution and provided commentary on proposed changes to the draft. The May 1977 Draft Constitution then will be compared with the final version of the 1977 USSR Constitution. Such a comparison will reveal some relatively minor changes that are of great importance to Soviet nationality policy. Indeed, it will be shown that Developed Socialism as enshrined in the 1977 USSR Constitution also included an attempt by Moscow to tighten control over the Soviet periphery. This chapter concludes with a comparison of the 1936 Union Republic constitutions with the new Union Republic constitutions ratified in 1978 both to show that overall Moscow attempted to tighten control, but failed to do so on occasion and to show that the new Union Republic constitutions maintained the principle of regional diversity in terms of nationality policy.

\section{The 1977 Constitution - Consolidating the Empire}

Compared with the 1977 USSR Constitution, the 1936 USSR Constitution is a relatively basic document that establishes the foundation of the Soviet economic and political system. Article 1 of the 1936 USSR Constitution states that "The Union of Soviet Socialist Republics is a

socialist state of workers and peasants." Article 2 states "The political basis of the USSR is the Council of Workers' Deputies, which grew and became strong as a result of the overthrow from power of the landlords and capitalists and the establishment of the dictatorship of the 
proletariat." Article 4 explains that "The economic basis of the USSR is the socialist economic system and the socialist ownership of the means of production, firmly established as a result of the liquidation of the capitalist economic system..." Articles 5 through 12 of the 1936 USSR Constitution further explain the Soviet economic system with Article 11 stating that "The economic life of the USSR is determined and directed by the state national-economic plan in the interests of increasing public wealth, the steady rise of the workers' material and cultural level, and the strengthening of the independence of the USSR and reinforcing its security." These first articles, then, outline the fundamental structure and character of the Soviet economy, naturally stating that this is a socialist economy based on the "state national-economic plan", better known as the Five Year Plan. But curiously absent from these first 12 articles of the 1936 USSR Constitution is any reference to Marxism-Leninism or to the Communist Party of the Soviet Union. As will be discussed later in this section, the 1977 USSR Constitution strongly emphasizes that the Soviet Union is based on Marxist-Leninist ideology and is led by the Communist Party.

Section II of the 1936 USSR Constitution outlines the state structure of the Soviet Union. Article 13 establishes that "The Union of Soviet Socialist Republics is a federal state, formed on the basis of the voluntary union of the various Soviet Socialist Republics." Article 13 (revised after the incorporation of the three Baltic republics and Moldavia) then lists the union republics in the following order: Russia, Ukraine, Byelorussia, Uzbekistan, Kazakhstan, Georgia, Azerbaijan, Lithuania, Moldavia, Latvia, Kyrgizstan, Tajikistan, Armenia, Turkmenistan, and Estonia. Official Soviet publications always list the union republics in this order, with the three Slavic republics listed first. This ordering of the republics reinforces the concept of regional 
diversity in nationality policy in that the Slavic republics receive first mention, implying that these are the most important union republics.

The principles of Soviet federalism are established in the remaining articles of Section II of the 1936 USSR Constitution. Article 14 lists the powers of the federal government, which include "a) The representation of the USSR in international relations, the ratification and denunciation of the treaties of the USSR with other states, the adoption of a common procedure [obshchego poriadka] governing the mutual relations of the union republics with foreign states..." In addition, Article 14 grants the federal government the authority to admit new union republics into the USSR, the right to approve changes to the borders of the union republics, the approval of a "single state budget of the USSR" including the education budget for the USSR as well as for the union republics and localities, and other questions such as declaring war and establishing laws on citizenship.

Articles 15 through 18 list the powers retained by the union republics. Article 15 states "The sovereignty of the union republic is limited only to the extent specified in Article 14 of the Constitution of the USSR. Outside of these limits, each Union republic exercises state power independently. The USSR protects [okhraniaet] the sovereign laws of the union republics." Moreover, according to Article 16, "Each Union republic has its own constitution, taking into account the peculiarities of the republic and in full compliance with the Constitution of the USSR.” Of greater significance for Soviet federalism is the provision in Article 17 that states "Each Union republic is guaranteed the right to freely leave the USSR." Article 18-a states that "Each Union republic has the right to enter into direct relations with foreign states and to conclude with them agreements and to exchange diplomatic and consular representatives" while Article 18-b allows each union republic the right to establish its own military formations. In 
theory, then, according to the 1936 USSR Constitution, the union republics retained much sovereignty including the rights to establish direct foreign relations, to secede from the USSR, and to maintain their own military formations. Later in this section, it will be shown that these rights are mostly retained in the 1977 USSR Constitution (except for the right of each union republic to maintain its own military formations), but the wording of these rights will be altered slightly in such a way as to weaken the sovereignty of the union republics.

Other sections of the 1936 USSR Constitution outline the structure of the USSR government and the governments of the union republics and the autonomous republics. Article 30 establishes the USSR Supreme Soviet as the highest organ of state power in the Soviet Union. The USSR Supreme Soviet is the legislative body of the Soviet Union consisting of two houses: the Soviet of the Union and the Soviet of Nationalities. Article 34 states that the Soviet of the Union is elected by districts with each deputy representing 300,000 citizens. Article 35 concerns representation in the Soviet of Nationalities with deputies distributed as follows: 25 deputies from each union republic, 11 from each autonomous republic, five deputies from each autonomous oblast, and one deputy from each national okrug. The 1977 USSR Constitution will slightly alter these numbers. Article 40 stipulates that laws passed by the USSR Supreme Soviet "shall be published in the languages of the union republics over the signatures of the Chairman and the Secretary of the Presidium of the USSR Supreme Soviet." Finally, Section IV of the 1936 USSR Constitution establishes the republic Supreme Soviets as the highest organs of state power in each union republic. Legislatively, then, the lower house of the Supreme Soviet, the Soviet of the Union, is elected solely on the basis of population without regard to the Soviet Union's constituent territorial units while the upper house, the Soviet of Nationalities, affords 
equal representation to the union republics and to the lower-level autonomous units such as autonomous republics and oblasts.

Section V of the 1936 USSR Constitution details the organs of state administration for the Soviet Union. Article 64 states that the USSR Council of Ministers is the highest organ of state administration in the Soviet Union. Of interest in Section V is Articles 68, 77, and 78. Article 68 outlines the powers and duties of the USSR Council of Ministers, which includes "Coordinates and directs the work of of all-union and union republic Ministries of the USSR and other insitutions subordinated to it..." Articles 77 and 78, interestingly, determine which ministries are all-union ministries and which ones are republic-level ministries. Article 77 gives to the all-Union Council of Ministers the ministries of Internal Trade, Navy, Railways, Medium Machine Building, Electric Power, and Transportation. According to Article 78, the union republic ministries include Internal Affairs, High and Secondary Specialist Education, Geology and Natural Resources, Health, Foreign Affairs, Culture, Defense, Communications, Rural Economy, and Finance. Article 78, then, seems to provide some wide-ranging autonomy to the union republics by entrusting to them such ministries as Internal Affairs, Natural Resources, Foreign Affairs, and Defense. It therefore appears that the 1936 USSR Constitution allowed the union republics to retain a considerable amount of sovereignty. But it should be emphasized that many of the provisions of the 1936 USSR Constitution (as well as the 1977 USSR Constitution) existed only as de jure rights and never became de facto rights and privileges. It must also be remembered that the Communist Party's monopoly of political power in the Soviet Union and its principle of democratic centralism ensured that many of the rights and privileges afforded to the union republics in the constitution would never actually be practiced in fact. Despite this reality, however, neither the provisions of the 1936 USSR Constitution, nor the provisions of the 1977 
USSR Constitution, should be ignored or dismissed because they provide insight into the changing nature of Soviet law and the Kremlin's attitude toward the principles of Soviet federalism and toward overall nationality policy.

Section IX of the 1936 USSR Constitution concerns the Soviet judicial system. This section reveals some interesting nuances found in Soviet federalism and which will be points of debate and discussion in 1977. Article 104 states that the USSR Supreme Court is the Soviet Union's highest judicial organ. Article 105 states that the Supreme Court members are chosen by the USSR Supreme Soviet with the chairmen of the union-republic supreme courts serving as ex officio members of the USSR Supreme Soviet. Thus the union republics were guaranteed equal representation on the high court. The rights of nationalities and of national minorities are protected in Article 110 which states "Judicial proceedings are conducted in the language of the Union or Autonomous Republic or autonomous oblast, with provision for those who do not know that language to be fully apprised of the case through an interpreter, as well as the right to address the court in their native language."

An interesting feature of Soviet federalism, however, concerns the office of procurator, the equivalent of the office of attorney general in the United States. Article 114 states that the USSR Procurator General is to be chosen by the USSR Supreme Soviet for a term of seven years. But interestingly, Article 115 states "The republic, krai, and oblast procurators, as well as the procurators of the autonomous republics and the autonomous oblasts are appointed by the Procurator General of the USSR for a term of five years." Article 115 ensures central control over the Soviet Union's law enforcement and the execution of those laws. The provisions in Article 115 would be similar to a provision in the United States Constitution allowing the United States Attorney General to appoint the attorneys general for each of the fifty states. Article 115, 
then, reserves much legal authority to Moscow by preventing the union republics or the autonomous republics from appointing their own procurators general. As will be discussed later in this section, the provisions of Article 115 will be a point of discussion and debate at the May 1977 Central Committee Plenum, which will result in the retention of these provisions in the 1977 USSR Constitution.

Section X of the 1936 USSR Constitution can be thought of as the Soviet Union's Bill of Rights. The articles contained in Section X outline the fundamental rights and responsibilities of each Soviet citizen. Several of these articles have a direct or indirect impact on Soviet federalism and Soviet nationality policy. Article 121 guarantees to Soviet citizens the right to an education, including the right to "training in the native language." Article 122 declares women to be equal to men under Soviet law. Article 123 directly addresses the Soviet nationality question by declaring "The equal rights of the citizens of the USSR, regardless of their nationality and race, in all areas of economic, state, cultural, and social-political life is a fundamental law. Any direct or indirect restriction of rights or, on the contrary, the establishment of direct or indirect privileges for citizens based on race or nationality, as well as any advocacy of racial or national exclusion, hatred, or contempt is punishable by law."

As noted at the beginning of this section, there had been discussion regarding the necessity of drafting a new constitution since the Khrushchev days. As the 1960s progressed and through the 1970s, the reasons why the Soviet Union needed a new constitution became more clear. Such reasoning culminated in a speech delivered by Brezhnev to the May 1977 Central Committee Plenum at which members of the Central Committee reviewed the latest draft of the proposed new constitution and suggested changes to the draft. In this speech, Brezhnev said, "First question: why was it necessary to draft a new constitution? Because, comrades, over the 
last four decades in our country, our society has undergone deep change." He then stated that when the 1936 USSR Constitution was ratified, the Soviet Union had only just begun building the basis of socialism. But, Brezhnev stated, "Today in the Soviet Union, there has been built a developed, mature socialist society. Major, fundamental changes have affected all aspects of social life." More specifically, Brezhnev said, "There has been developed and successfully implemented a single, powerful national economic organism."3 Later in Brezhnev's speech to the May 1977 Plenum, he announced to the members of the Central Committee that "It is also stated in the Draft of the new Constitution that there has been established in the USSR a developed socialist society and that the highest goal of the Soviet state is the building of communism. It is emphasized that ours is an all-national [obshchenarodnyi] state reflecting the will and the interests of the working class, the collective farm peasantry, the national intelligentsia, and all of the nations and nationalities of the country." ${ }^{4}$ In essence then, Brezhnev is arguing that much has changed in the Soviet Union since the mid-1930s, the country has finished building socialism and has achieved the stage of Developed Socialism which allows the Soviet Union to begin the road to communism. Thus, the primary purpose of the 1977 USSR Constitution is to enshrine into the Soviet Union's basic law Brezhnev's theory of Developed Socialism.

Moreover, Brezhnev also applied the precepts of Developed Socialism to the nationalities issue in his speech at the May 1977 Plenum. He emphasized that "We have established not only de jure, but the de facto equality of nations. All of our republics, including those that previously lagged behind in economic and cultural relations, have now reached high levels of development. At the same time, the economy of each republic has become an integral part of the single national-economic complex." Brezhnev's last assertion regarding a "single national-economic 
complex" is significant as it implies a slight erosion of the union republics' sovereignty within the Soviet system and of course is one of the central tenets of Developed Socialism. This will be discussed in greater detail later in this section. But despite alluding to the Soviet Union as a single national-economic complex without delving into precisely what this means regarding nationality policy, Brezhnev later asserted, "Comrades! The Soviet Union is a multinational state. Experience has shown that the main features of the Soviet Union's federal system have fully justified themselves. Therefore, there is no need to make any fundamental changes to the forms of the soviet socialist federation. The draft reflects a new stage in the development of our national economy. It shows that the economy of the USSR has been transformed into a single national-economic complex, encompassing all links in social production, distribution, and exchange in the country's territory."6 Here, Brezhnev is answering earlier calls from some within the Communist Party suggesting that the nationality issue had been so resolutely solved that there was no longer any need to retain the Soviet Union's federal structure; the union republics and other nationality-based territorial units could be abolished, according to some Party officials. But abolishing the union republics and Soviet federalism would be putting the cart before the horse. Presumably, as the rapprochement of nations continued and the Soviet man continued to mature as predicted by Developed Socialism, such a radical transformation of the Soviet structure could occur. But Brezhnev was not ready to take such a major step in 1977. Yet, he repeats the idea that the Soviet Union had evolved into a "single national-economic complex", which again implies a certain erosion of the principle of Soviet federalism.

Finally in his speech to the May 1977 Plenum, Brezhnev claimed that "A new historical community of people has been formed - the Soviet people." ${ }^{\text {, }}$ This, he claimed, was the natural result of the ongoing process of the rapprochement (sblizhenie) of the peoples of the Soviet 
Union, a theme the Soviet leadership had been emphasizing since the late 1960s. Brezhnev also announced a fundamental change in the administrative structure of the Soviet Union when he said, "Unlike in the present Constitution, the draft does not list union and union-republic ministries and agencies. Given that, as experience has shown, their composition varies from time to time, it was considered more appropriate to place the list in a special law on the USSR Council of Ministers, the adoption of which is provided for in Article 132 of the Constitution." 8 While on the surface, eliminating the differences between union and union-republic ministries does seem to be an appropriate "house-cleaning" measure for the new constitution, as Brezhnev indicated, it is yet another act of eroding the de jure sovereignty of the union republics. Again, as noted previously, while many of the de jure aspects of republic sovereignty never existed de facto, the act of eroding even the de jure nature of republic sovereignty is an important symbolic act as it signals an attempt by the Kremlin to consolidate its power over the Soviet periphery.

The materials from the May 1977 Central Committee Plenum are important for understanding the development of the 1977 USSR Constitution as they offer a glimpse into the intra-party discussion that took place shortly before the final draft of the constitution was adopted. Most importantly, the materials from the May 1977 Plenum contain the latest draft of the Constitution as well as remarks and notes from Central Committee members suggesting revisions to this draft in addition to stenographic reports of the various speeches delivered at the end of the Plenum. In light of this, I will discuss the May 1977 Plenum in some detail along with the draft constitution that the Central Committee worked on at this crucial meeting. The materials from the May 1977 Plenum reveal some important changes between the Draft Constitution and the final version of the Constitution as well as some of the internal thought process among some Central Committee members. Overall, the May 1977 Plenum reveals that 
there was at least some push-back against the Brezhnev leadership's moves to centralize authority in Moscow and the leadership's efforts to tighten control over the Soviet periphery. Most attempts to curb the centralizing trend failed, but the mere fact that the attempts were made reveals that some in the CPSU were at least concerned with the Brezhnev leadership's efforts to consolidate further the Soviet Empire and thus not fully convinced of the correctness of Developed Socialism.

Unlike the 1936 USSR Constitution, the 1977 USSR Constitution contains a rather lengthy Preamble that summarized the history of the Soviet Union and declared that the country had now entered the stage of Developed Socialism. ${ }^{9}$ The Preamble in the Draft Constitution presented to the May 1977 Plenum drew the attention of Nikolai Shchelokov, the USSR Minister of Internal Affairs. Contained in the materials of the May 1977 Plenum is a letter from Shchelokov in which he offers his thoughts and commentary on the Draft Constitution. In the Draft Constitution's Preamble, it states “The Great October Socialist Revolution, completed [sovershennaia] by the workers and peasants of Russia under the leadership of the Communist Party led by V.I. Lenin, overthrew the capitalists and landlords, broke the shackles of oppression and created the Soviet state..." Shchelokov took issue with the wording in this passage. In his letter to the Constitutional Commission of the Central Committee, Shchelokov wrote, "In the Preamble, it should read 'the revolution in Russia, completed by the workers and peasants...' and not 'the revolution, completed by the workers and peasants of Russia.' It demeans the role in the revolution of the workers and peasants of the national borderlands of Russia." ${ }^{11}$ Here, Shchelokov seems to disagree with the policy of elevating the Russian people to the status of first among equals among the peoples of the Soviet Union. Indeed, the Preamble is the only place in both the Draft and in the final version of the 1977 USSR Constitution in which the word 
Russia appears, other than in a later article where all 15 union republics are listed. Shchelokov is correct, though, that the proposed wording of this passage in the Preamble does suggest that the Russian workers and peasants are of higher status than the non-Russians, which would be in accordance with the tenets of Developed Socialism. Moreover, it is significant that the Minister of Internal Affairs - a man who would likely have been intimately familiar with the nationalities issue in the Soviet Union - would suggest that the Preamble's wording "demeans the role in the revolution of the workers and peasants of the national borderlands of Russia." Although it is uncertain because Shchelokov does not further explain his reasoning in his letter to the Constitutional Commission, it is likely that Shchelokov took such a position regarding the passage in the Preamble because he himself was from the national borderlands, having been born in Eastern Ukraine. Whatever the motivation behind Shchelokov's protest, the Central Committee did not take his advice and that passage's wording remained unchanged in the final version. Despite Shchelokov's failure to convince the Central Committee to change the wording of the Preamble, his commentary is still significant as it reveals at least some disagreement within the Brezhnev leadership regarding the nationalities issue. Though Shchelokov did not seem to take issue with the overall trend in the 1977 USSR Constitution of further consolidating the Soviet Empire, his commentary on the Preamble does at least reveal some resistance to the Brezhnev leadership's course of elevating the status of the Russian people.

As discussed earlier in this section, Article 115 of the 1936 USSR Constitution provided that the Procurator General of the USSR appoints the procurators of each union republic, which, as noted above, allowed Moscow to retain much control over the Soviet Union's legal system. The topic of the procedure by which union republic procurators should be chosen presented itself at the May 1977 Plenum. At the Plenum, Candidate Member of the CPSU Central Committee 
and the Chairman of the Moldavian Supreme Soviet Kirill F. Il'iashenko proposed an argument in favor of changing the procedure by which republic procurators are selected. Within the packet of materials at the May 1977 Plenum labeled "K.F. Il'iashenko" is a short note in which Il'iashenko apparently defends a proposal that would allow the republic Supreme Soviets to have greater input and control over the appointment and activities of the republic procurators. Unfortunately, the materials for the May 1977 Plenum do not contain a specific proposal from anyone in attendance at the Plenum recommending such a change. The only reference is this short note from Il'iashenko. Il'iashenko's note, however, is rather enlightening.

Il'iashenko's note is entitled 'Explanation of the Proposed Presentations in Articles 162 and 164." In his note, Il'iashenko apparently references proposed changes to two specific articles in the Draft Constitution: Article 162 and Article 164. Article 162 of the Draft Constitution states "The Procurators of the union republics, autonomous republics, krais, oblasts, and autonomous oblasts are appointed by the USSR Procurator General. The Procurators of the autonomous okrugs and the regional and city procurators are appointed by the procurators of the union republics with the approval of the USSR Procurator General." ${ }^{12}$ Article 162 of the Draft Constitution, then, simply combines Articles 115 and 116 of the 1936 USSR Constitution and so therefore does not change the procedure for appointing republic and local procurators. Article 164 of the Draft, referenced in Il'iashenko's note, states “The Procurators exercise their powers independently of any local government organ, obeying only the Procurator General of the USSR." Article 164 of the Draft is identical to Article 117 of the 1936 USSR Constitution. Based on Il'iashenko's note, it is apparent that there was a proposal at the May 1977 Plenum to change Articles 162 and 164 of the Draft to allow the republics to have greater input into the selection of republic procurators and to have greater local control over the activities of 
the republic procurators. Whereas Article 164 of the Draft states that the republic-level procurators are independent of any local control, Il'iashenko writes in his note that the proposed change to this article would simply provide that the procurator and the procurator organs "are guided only by law subject to the General Procurator of the USSR. Thus, the Supreme Soviet of the republic may influence the activities of the prosecutors only through their laws." Il'iashenko explains that this proposed change would not be problematic because "If the laws of the republics do not comply with the Union [laws], according to Article 72, in the event that republic laws conflict with all-union laws, the all-union laws apply."13 Thus, Il'iashenko argues, the basic provisions of Soviet federalism would protect Moscow's interests in the event that the republics are given greater control over their respective procurators. Moscow need not fear losing influence in the legal systems of the republics.

Il'iashenko also defends proposed changes to Article 162 of the Draft. Apparently, based on Il'iashenko's note, the proposed change to Article 162 would have allowed the republics themselves to select their own procurators. Il'iashenko defends this suggestion, writing that "The appointment of Union Republic procurators by the republic Supreme Soviet and, therefore, their accountability to the Supreme Soviets does not prevent their subordination to the General Procurator and the exercise of their powers independently from the local organs. Also the accountability of the republic Supreme Courts to the republic Supreme Soviets does not place the courts into any kind of dependence upon local organs in the exercise of justice as Article 151 stipulates such independence." In essence, Il'iashenko is arguing that the country can have it both ways - the republic Supreme Soviets can select their own procurators while the USSR Procurator General can still exercise influence. 
But Il'iashenko's most important argument in favor of allowing the republic Supreme Soviets to appoint procurators concerns the role of the Party and the nomenklatura system for selecting cadres. Il'iashenko writes, "The appointment of Union Republic procurators by the corresponding Supreme Soviets does not prevent the Procurator General from having influence on the selection of cadres. Also, the Union Ministries are not excluded from the selection of ministers of the Union Republic ministries, although this is not written in the Constitution. With the ever-increasing role of the party and the entrenched practice of the recruitment and selection of cadres by party organs, there is no place for such fears [emphasis added]." Here, Il'iashenko admits that the Party's system for selecting cadres - which is not found in the USSR Constitution - will ensure that the center retains much influence on the selection of procurators at the republic level. Thus, Il'iashenko is attempting to allay the fears of Party members who may fear Moscow's losing control of the local-level legal system in the Soviet Union. But Il'iashenko goes even further to defend the proposed change to the procedure of appointing procurators. He also defends the proposal on the basis of the republics' sovereignty - likely a novel argument in the overall atmosphere of eroding the republics' sovereignty. Il'iashenko writes, "The necessity of the establishment of the proposed procedure for the appointment of Union Republic procurators arises both from the standpoint of sovereignty and of the principle that the republic Supreme Soviet, as the highest legislative organ, should promote and respect the laws of the country on its territory and therefore there must be provided a special organ that would exercise direct supervision over the implementation of laws in the republic." ${ }^{14}$ Il'iashenko, then, is defending the principles of republic sovereignty and of Soviet federalism in this argument.

Il'iashenko's note is the most candid defense of the union republics' sovereignty found in the materials of the May 1977 Plenum. Most of the other materials - especially the speeches 
delivered at the end of the Plenum - are largely propagandistic in nature, as will be discussed below. That Il'iashenko wrote his note as the Chairman of the Moldavian Supreme Soviet strongly suggests that Il'iashenko supported a power grab on the part of the union republics, albeit a rather weak one. It is also evidence again of an attempt - however weak it was - at the May 1977 Plenum to scale back the overall trend found in the final version of the 1977 USSR Constitution of further centralizing power in the Soviet Empire through subtle alterations that at least symbolized an erosion of union republic sovereignty. As will be discussed in the next section, however, the strongest resistance to the Brezhnev leadership's attempts to erode union republic sovereignty came in the adoption of new union-republic constitutions in 1978.

As noted above, most of what is found in the May 1977 Plenum materials is propagandistic in nature, particularly the speeches delivered. Yet the propaganda does yield some insight into the nature of the Brezhnev leadership's thinking on the nationalities issue. The notes and speeches from Central Committee members from the Central Asian republics and from Ukraine reveal a uniformly propagandistic support for the Draft Constitution. Indicative of this apparently strong support for the new Constitution is a letter from F. Shamsudinov, First Secretary of the Fergana Oblast Party Committee in Uzbekistan. Here, Shamsudinov simply writes, "I have carefully studied the Draft of the new Constitution of the USSR. The text of the draft of the basic law of our state corresponds with the internationalist spirit of a developed socialist society and for the further legal measures for the building of communism in the USSR. I do not have any comments on the draft Constitution of the USSR." ${ }^{\prime 15}$ Fellow Uzbek Party Member M.M. Musakhanov, First Secretary of the Tashkent Oblast Party Committee, delivered a speech at the May 1977 Plenum in which he went out of his way to praise the new Draft Constitution. In his speech, Musakhanov noted that "In our country, a developed socialist 
society has been built and the Soviet state has become all-national [obshchenarodnyi]." As a result of this, Musakhanov emphasized, "The workers of Uzbekistan, as well as all of the Soviet people, warmly approve and unanimously support the internal and external policies of the party..." Musakhanov then detailed what the Draft Constitution meant for Soviet nationality policy: "The new Soviet Constitution conforms to the fundamental interests of the Soviet people, their hopes and aspirations, and it guarantees the further development of socialist democracy, the expansion of the rights and freedoms of citizens, and the comprehensive flowering and steady rapprochement of all of the nations and nationalities of the country." More specifically, Musakhanov emphasized Uzbekistan's place in the USSR of Developed Socialism when he stated that "Soviet Uzbekistan today is an inextricable part of the single national-economic complex of the country, is mighty socialist industry, the highly developed and diversified rural economy, and advanced science and culture." He then added the now-obligatory acknowledgement of the aid Uzbeks have received from the Russians by stating that "The progress of the republic's workers is a brilliant example of the triumph of our party's national policy, of the unbreakable brotherhood, unity, friendship and assistance of all of the Soviet peoples and above all from our elder brother, the Great Russian people." Finally, Musakhanov noted, "The participants of this Plenum from the Communist Party of Uzbekistan, in the name of the more than half-million strong army of communists of the republic, entirely approve of all of the provisions of the articles of the new Constitution and express sincere thanks to the Politburo and to Leonid Il'ich Brezhnev for their great and hard work on the design and creation of the draft Constitution."16

Along with Musakhanov, V.V. Shcherbitskii, the First Secretary of the Ukrainian Communist Party, who had recently replaced the ousted Petro Shelest, also highly praised the 
Draft Constitution and the successes of the Party's Leninist nationality policy. In his speech to the May 1977 Plenum, Shcherbitskii declared, "Comrades! The new Constitution is certainly the triumph of our party's Leninist national policy and of the unbreakable friendship of all of the nations and nationalities of our country and, it can be said, is the theme [gimn] of our great brotherhood. The draft emphasizes that the USSR is a single federal multinational state that embodies the united Soviet people and rallies all of the nations and nationalities to the joint building of communism." Shcherbitskii added that "The single national-economic complex consists of the economy of our country, which also serves as a reliable foundation for the dynamic development of each republic and is the key to the successful fulfillment of all economic and political tasks...we will always cherish and strengthen our single federal state and the unbreakable friendship of the Ukrainian people with the Russian people and with all of the fraternal peoples of our country."17 Thus, like Musakhanov of Uzbekistan, Shcherbitskii pays homage to the Russian people as the first among equals of Soviet nations. This praise of the Russian people is further evidence of both the Brezhnev leadership's attempt through the new Constitution to consolidate further Moscow's control over the Soviet periphery as well as the continuation of regional diversity in regard to nationality policy. Because Shelest had been removed for tolerating too much Ukrainian nationalism, Shcherbitskii had to be careful to praise both Brezhnev and the Russian people. In this respect, the Brezhnev leadership has successfully retained its tighter control over a Slavic republic. In the case of Musakhanov's praise of the Russian people and of Uzbekistan's inextricable place within the Soviet single-economic complex, it is likely that he was simply following Rashidov's example of heaping disingenuous praise on the Russian people and the successes of Leninist nationality policies. Because Uzbekistan belonged to the distant periphery of the Soviet Empire and was not Slavic, Rashidov 
and his comrades in the Uzbek Party could pay lip service to the Great Russian people while still maintaining a degree of autonomy within the Soviet Empire.

Perhaps the greatest praise at the May 1977 Plenum for the Draft Constitution came from E.N. Auel'bekov, First Secretary of the Kokchetavskii Oblast Party Committee in Kazakhstan. As with Shcherbitskii's speech, Auel'bekov's speech highlighted the positive aspects of the Soviet Union as a single economic complex. Auel'bekov declared, "Comrades! Due to the correct social-economic policy of the party, all of our fraternal republics have developed and are developing a single national-economic complex that effectively promotes both the confident and inclusive growth of the country as a whole and each republic separately. Tremendous changes have taken place in our country which are reflected in the document in question and can be clearly demonstrated with the example of multinational Soviet Kazakhstan.” Due to these “tremendous changes", Auel'bekov noted, "During the years of Soviet power, relying on the selfless assistance and support of the Great Russian and other fraternal peoples, the previously destitute Kazakh people was revived to light and creation, and rose to the heights of potential progress. As correctly pointed out by Leonid Il'ich in his brilliant keynote speech to the partyeconomic aktiv in Alma-Ata on 3 September 1976, Kazakhstan today is one of the basic granaries of the Soviet Union, the largest livestock base of the country. Kazakhstan today is hundreds of modern industrial enterprises, which are making a great contribution to the economic development of the country."18 Here, Auel'bekov's speech takes on a religious tone as the Great Russian people led the "destitute Kazakhs" to "light and creation."

The USSR Supreme Soviet officially adopted the new 1977 USSR Constitution on October 7, 1977. While the new 1977 USSR Constitution retained most of the basic features of the 1936 USSR Constitution, it did add some additional concepts that either are not found in the 
1936 USSR Constitution or are only vaguely referred to in the 1936 version. The most obvious change is the inclusion of the Preamble in the 1977 USSR Constitution. As noted above, the Preamble essentially states the purpose for the new Constitution and it contains a brief history of the Soviet experience to support the purpose for the new Constitution. More specifically, however, the Preamble introduces several new concepts into the Soviet Union's basic law that were absent from the 1936 Constitution. First, the Preamble in a rather vague way introduces the concept of Russia as first among equals. As discussed above regarding the discussions at the May 1977 Central Committee Plenum, the Preamble states “The Great October Socialist Revolution, completed by the workers and peasants of Russia under the leadership of the Communist Party led by V.I. Lenin, overthrew the capitalists and landlords... and created the Soviet state..." It will be recalled that Il'iashenko, the Chairman of the Presidium of the Supreme Soviet of Moldavia, objected to this particular language as in his opinion it "demeaned" the role of the non-Russian peoples in the Revolution. Yet, Il'iashenko's objections were rejected. To be sure, this passage does not overtly declare the Russian people to be the first among equals, but as Il'iashenko convincingly argued at the May 1977 Plenum, it seems to infer as much.

Secondly, the Preamble declares that "a developed socialist society has been built in the USSR." A developed socialist society is "a society of mature socialist social relations, which is the basis of the rapprochement [sblizhenie] of all classes and social strata, the juridical and de facto equality of all nations and nationalities, and their fraternal cooperation has created a new historical community of people - the Soviet people [Sovetskii narod]." The Preamble also states that, among other things, the developed socialist society is "a natural stage on the path to 
communism." This, then, is the primary purpose of the 1977 USSR Constitution - the insertion of Brezhnev's theory of Developed Socialism into the Soviet Union's fundamental law.

The third and final new concept introduced by the Preamble is that of the Soviet people (Sovetskii narod). The Preamble states that the Soviet people are "guided by the ideals of scientific communism and is true to their revolutionary traditions."

Overall, the primary difference between the 1977 USSR Constitution and the 1936 USSR Constitution is that the 1977 USSR Constitution erodes certain aspects of the Union Republics' sovereignty. Moreover, the 1977 USSR Constitution explicitly gives the Communist Party of the Soviet Union sole power in the Soviet political, social, and economic systems, a concept that is curiously missing in the 1936 USSR Constitution. For example, Article 3 of the 1977 USSR Constitution states that "The organization and activities of the Soviet state are built in accordance with the principles of democratic centralism...Democratic centralism combines central leadership with local initiative and creative activity with the responsibility of each state organ and official for the work entrusted to them." Democratic centralism, of course, had always been one of the guiding principles of the Communist Party, but this is the first time that democratic centralism had been associated with the functioning of the Soviet State. This can be interpreted as a subtle - and perhaps even an unintended - way to consolidate further the Soviet Empire. If democratic centralism is now a guiding principle for the functioning of the state, this in theory would mean that the periphery of the Soviet Empire would have even less leeway in implementing the state's policies. To be sure, because of the Communist Party's de facto monopoly on political power in the Soviet Union, democratic centralism had always therefore been in force, which is one reason why the Soviet Union had always functioned as an empire. 
But enshrining the principle of democratic centralism in the Soviet political system officially declares the further consolidation of the Soviet Empire.

Article 6 of the 1977 USSR Constitution introduces a vital concept that is curiously absent in the 1936 USSR Constitution. Article 6 states that "The leading and guiding force of Soviet society and state, the leading core of the political system and of state and social organizations is the Communist Party of the Soviet Union. The CPSU exists for the people and serves the people." Thus, the 1977 USSR Constitution legally recognizes the Party's role in the Soviet state and society. Moreover, Article 6 states "Guided by Marxism-Leninism, the Communist Party determines the general perspective of the development of society, the line of the USSR's internal and external policies, guides the activities of state and social organizations, and gives a systemic, scientifically based character to the Soviet people's struggle for the victory of communism." For the first time, the Soviet Constitution declares that the Communist Party is the sole authority in the Soviet Union and for the first time, Marxism-Leninism is referenced in the Soviet Constitution. The Party's role in the Soviet Union as well as Marxism-Leninism are not referenced at all in the 1936 USSR Constitution.

But of greater significance than the Constitution's recognition of the Party's predominant role in the Soviet state and society is the 1977 USSR Constitution's erosion of the Union Republics' sovereignty, which results in the de jure consolidation of the Soviet Empire. Evidence for the de jure erosion of Union Republic sovereignty is apparent in Section II of the 1977 USSR Constitution. Section II describes the Soviet Union's economic system. As expected, the articles contained in Section II state that the "basis of the economic system of the USSR is the socialist ownership of the means of production" (Article 10) and that "State ownership is the common heritage of the entire Soviet people and is the primary form of socialist 
property" (Article 11). But Article 16 is the most significant in terms of Soviet nationality policy. Article 16 states that "The economy of the USSR is a single economic complex comprising all elements of social production, distribution and exchange in the country." For the first time in Soviet history, the Soviet Union is described as a single economic unit. Therefore, Article 16 can be construed as an effort to consolidate further central control of the Soviet Union's economy and thus, further consolidation of the center's control over the Soviet periphery. If the Soviet Union is now constitutionally considered to be a single economic complex, that therefore suggests that the Union Republics have less autonomy in economic policy-making. Moreover, Article 16 suggests that ideas such as Khrushchev's regionally-based sovnarkhozy would now be rendered unconstitutional as they would seem to violate the concept of the Soviet Union as a single economic complex. Although subtle and most likely the result of the Brezhnev leadership's ongoing efforts to promote the theory of Developed Socialism, Article 16 's provisions indicate a further erosion of Union Republic sovereignty.

Section VIII of the 1977 USSR Constitution delineates the federal structure of the Soviet Union and describes the functioning of Soviet federalism. Interestingly, the 1977 USSR Constitution relegates this very important issue to Section VIII - in the middle of the Constitution - whereas the 1936 USSR Constitution placed the federal system in Section II, near the beginning of the document. While no mention of the change in the placement of this section is made at the May 1977 Plenum, given the general atmosphere at that Plenum it can be suggested that relegating the 1977 Constitution's section on the federal system to the middle rather than near the beginning reflects the attitude that the concept of Soviet federalism is not as important in 1977 as it was in the 1930s. That some within the Party suggested that federalism be done away with altogether is evidence of this change in focus. Nevertheless, the 1977 USSR 
Constitution's description of the Soviet federal system is largely similar to that found in the 1936 USSR Constitution, though with certain subtle, yet important differences.

Article 13 of the 1936 USSR Constitution states that "The Union of Soviet Socialist Republics is a federal state formed on the basis of the voluntary union of the equal Soviet Socialist Republics.” Article 13 then lists the Union Republics in this order: Russia, Ukraine, Byelorussia, Uzbekistan, Kazakhstan, Georgia, Azerbaijan, Lithuania, Moldavia, Latvia, Kirghizia, Tajikistan, Armenia, Turkmenistan, and Estonia. In contrast, Article 70 of the 1977 USSR Constitution states "The Union of Soviet Socialist Republics is a united, federal multinational state, formed on the fundamental principle of socialist federalism, as a result of the free self-determination of nations and the voluntary association of equal Soviet Socialist Republics. The USSR embodies the state unity of the Soviet people and it unites all nations and nationalities for the joint construction of communism." Article 71 then lists all fifteen Union Republics in the same order as the 1936 USSR Constitution. Article 70 of the 1977 USSR Constitution, then, retains the same basic principle as described in Article 13 of the 1936 USSR Constitution, but the 1977 version adds some vital details such as the USSR as a "multinational state", the reference to the "free self-determination of nations", and "the fundamental principle of socialist federalism" - important phrases that are missing in the 1936 USSR Constitution. These additional phrases are largely of a Leninist nature in that Lenin consistently referred to national self-determination. Moreover, the additional details contained in the 1977 USSR Constitution are contradictory. Article 70 emphasizes the federal nature of the Soviet state yet it also notes the "state unity of the Soviet people" and the uniting of "all nations and nationalities for the joint contruction of communism." Article 70, then, suggests that the Soviet Union is both a multinational state yet is striving for the unity of all nations into a single Soviet people. 
Article 73 of the 1977 USSR Constitution is the equivalent to Article 14 of the 1936 USSR Constitution in that both articles delineate the authority of the federal government in Moscow. The powers given to the all-Union government are very similar in both constitutions. Yet, the 1977 USSR Constitution contains additional provisions that are missing from the 1936 USSR Constitution. For example, Article 75 of the 1977 USSR Constitution states "The territory of the Union of Soviet Socialist Republics is one and includes the territory of the union republics. The sovereignty of the USSR extends to its entire territory." The language of the 1936 USSR Constitution regarding the USSR's sovereignty is not nearly so explicit. Instead, the 1936 Constitution merely states that federal laws apply to all Union Republics and that federal law supersedes Union Republic law. Thus, the 1977 USSR Constitution more clearly and more forcefully describes the nature of the USSR's sovereignty. Article 75, then, can be viewed as a further strengthening of the center's powers over the periphery. In addition, Article 77 of the 1977 USSR Constitution is much more clear than the 1936 Constitution on the Union Republics' relations with the all-Union government in Moscow. This article states, inter alia that "The Union Republic shall ensure comprehensive economic and social development in its territory and facilitates the exercise on its territory of the powers of the Union SSR and enforces the decisions of the highest organs of state power and administration of the USSR." While the Union Republics had always enforced all-Union laws and policies in their respective territories, Article 77 is far more explicit in this area of federalism than the 1936 USSR Constitution.

Finally, the 1977 USSR Constitution contains two more fundamental differences from the 1936 USSR Constitution. Article 18-b of the 1936 USSR Constitution states "Each Union Republic has its own military formations." This provision is not found in the 1977 USSR Constitution. That the 1977 USSR Constitution eliminates the right of the Union Republics to 
maintain their own armed forces is a direct erosion of Union Republic sovereignty compared to the 1936 Constitution. Secondly, Article 18-a of the 1936 USSR Constitution states "Each Union Republic has the right to enter into direct relations with foreign states and to conclude with them agreements and to exchange diplomatic and consular representatives [emphasis added]." The 1977 USSR Constitution retains the right of the Union Republics to have relations with foreign states, but it changed the wording slightly. Article 80 of the 1977 USSR Constitution reads "The union republic has the right to enter into relations with foreign states, to conclude treaties with them and to exchange diplomatic and consular representatives with them..." Note that Article 80 of the 1977 USSR Constitution merely provides the Union Republics with the right to "enter into relations" with foreign states, not to enter into direct relations with foreign states. Admittedly, this is only a subtle change in wording, but it does carry some importance as it seems to place further limits on the Union Republics' abilities to engage with foreign states. To be sure, the 1936 USSR Constitution's guarantee of the right of Union Republics to enter into even direct relations with foreign states was always a fiction; no Union Republic ever established embassies in foreign capitals. But the importance here lies in the fact that overall, the 1977 USSR Constitution represents a de jure erosion of Union Republic sovereignty, which is of great symbolic significance even if it did not necessarily mean a change in the reality on the ground.

The differences described above notwithstanding, the 1977 USSR Constitution did retain many of the fundamental concepts of Soviet federalism found in the 1936 USSR Constitution. For example, according to Article 76 of the 1977 USSR Constitution, "The union republic is a sovereign soviet socialist state which has been united with the other soviet republics in the Union of Soviet Socialist Republics. Outside the limits specified in Article 73 of the USSR 
Constitution, the union republic independently carries out state power in its territory. The union republic has its own constitution, in accordance with the Constitution of the USSR, taking into account the particular nature of the republic." This is virtually identical to Articles 15 and 16 of the 1936 USSR Constitution. Moreover, Article 81 of the 1977 USSR Constitution states "The sovereign rights of the union republic are protected by the USSR." This provision is similar to a statement contained in Article 15 of the 1936 USSR Constitution.

In the area of the rights of citizens - in particular those rights that pertain in some manner to the nationalities issue - the 1936 and 1977 USSR Constitutions are very similar. One key difference, however, can be seen in comparing Article 123 of the 1936 USSR Constitution with Article 36 of the 1977 USSR Constitution. Article 123 of the 1936 USSR Constitution provides that "The equal rights of the citizens of the USSR, regardless of their nationality and race, in all areas of economic, state, cultural, and social-political life is a fundamental law. Any direct or indirect restriction of rights or, on the contrary, the establishment of direct or indirect privileges for citizens based on race or nationality, as well as any advocacy of racial or national exclusion, hatred, or contempt is punishable by law." In comparison, Article 36 of the 1977 USSR Constitution states "Citizens of the USSR of various races and nationalities have equal rights. The exercise of these rights is guaranteed by the comprehensive policy of the development and rapprochement [sblizhenie] of all the nations and nationalities of the USSR, the upbringing of the citizens in the spirit of Soviet patriotism and socialist internationalism, and the ability to use the native language and the languages of the other peoples of the USSR." Article 36 concludes with the same language as Article 123 regarding the prohibition of the restriction of rights or the provision of privileges based on nationality or race. Thus, Article 36 of the 1977 USSR Constitution provides the same rights as Article 123, but states further that these rights are the 
result of the process of sblizhenie and of the education of the Soviet people in the principles of Soviet patriotism and internationalism. Article 36 of the 1977 USSR Constitution, then, incorporates into the USSR's fundamental law the primary strategies of Brezhnev's nationality policy: the insistence on the rapprochement of nations and the education (or propaganda) of the Soviet people in the spirit of Soviet patriotism. As discussed earlier in this chapter, the Brezhnev leadership relied heavily on propaganda touting Soviet patriotism and internationalism in managing the nationality issue.

Beyond the differences discussed above, the 1936 and 1977 USSR Constitutions are similar in the rights afforded to citizens. Rights retained by the 1977 USSR Constitution include the right to an education and to schooling in one's native language (Article 45), the freedom of religion as well as the freedom to disseminate atheist literature (Article 52), and the "duty of each citizen of the USSR to respect the national dignity of other citizens, to strengthen the friendship of nations and nationalities of the Soviet multinational state" (Article 64) among other provisions. Finally, as discussed above in relation to the May 1977 Plenum, the 1977 USSR Constitution retained the provision that the USSR General Procurator has the power to appoint the Union Republic procurators, a right that was kept despite the protest from the Chairman of the Moldavian Supreme Soviet.

The 1977 USSR Constitution, then, was the crowning achievement of Brezhnev's tenure. It enshrined into the Soviet Union's fundamental laws the theory of Developed Socialism as well as Brezhnev's primary strategies for dealing with the Soviet nationality question such as reliance on education and propaganda and an effort to consolidate power at the center at the expense of the periphery. The 1977 USSR Constitution therefore is the culmination of the effort to strengthen the Soviet Empire both directly and indirectly. It must be emphasized, however, that 
in many respects the 1977 USSR Constitution merely reflected the realities of the Soviet system as it existed in the 1970s. For example, as noted above, democratic centralism had always been the norm in the Soviet political system and the Communist Party always had a monopoly on political power in the Soviet Union. The new Constitution merely gave these decades-old practices official legal standing. But it also must be remembered that even though the new Constitution did not necessarily make great changes to the everyday functioning of the Soviet Empire, it did contain significant symbolic changes. Symbolically, the 1977 Constitution reflects an effort by the Brezhnev leadership to tighten Moscow's control over the Soviet periphery by eroding Union Republic sovereignty through largely subtle changes in the phrasing of the new Constitution. This symbolism is a reflection of the Brezhnev leadership's approach to the Soviet nationality question. In the face of a developing decolonization process in many parts of the Soviet periphery, the Brezhnev leadership sought to counter this process through education and propaganda along with economic and constitutional policies that attempted to give Moscow greater control over the periphery. Ultimately, these efforts failed to consolidate more power in the hands of Moscow, as will be discussed in the next section, but generally Brezhnev's nationality policy did succeed in maintaining the Soviet Empire.

\section{Resisting the Empire: Union Republic Constitutions}

In this section, I will analyze the 1936 Union Republic constitutions and the new constitutions ratified in 1978 with particular focus on the 1978 documents. Each Union Republic, Autonomous Republic and Autonomous Okrug in the USSR had its own constitution. These constitutions were adopted in 1936 (or 1940 in the three Baltic Republics and Moldavia) and then new constitutions were ratified in 1978 to coincide with the new 1977 USSR 
Constitution. Because the Union Republic constitutions were very similar to one another (in many articles, they used the exact same phraseology), I will use the Russian Republic Constitutions as the example to discuss the primary features of the 1936 and 1978 Union Republic Constitutions and how these common features changed over time. The commonalities of the Union Republic constitutions will again reveal that the Brezhnev leadership in 1977-1978 used the new USSR and Union Republic Constitutions as an attempt to consolidate more power at the center of the Soviet Empire, in keeping with the goals of Developed Socialism. I will then analyze the differences between the 1978 Union Republic constitutions. The differences between the 1978 constitutions will reveal two important developments: first, the differences among the Union Republic constitutions show that there was some resistance in the Union Republics to the Kremlin's attempt to consolidate more power at the center. This resistance is especially evident in the three Caucasian republics. Second, the differences between these 1978 constitutions reinforce the regional diversity thesis, which becomes quite clear when analyzing the preambles to the 1978 Union Republic constitutions as well as the language provisions in the constitutions of Georgia, Armenia, and Azerbaijan. Thus, while the 1977 USSR Constitution and the 1978 Union Republic constitutions reveal the Kremlin's attempts to consolidate more power at the center, it must be remembered that these attempts to erode republic sovereignty were primarily symbolic in nature; the changes enacted in 1977-78 did not radically change the functioning of the Soviet system, the changes faced resistance from the Union Republics and finally, the new constitutions continued the practice of applying slightly different nationality policies in the various regions of the Soviet Union.

The 1936 RSFSR Constitution, as well as the other Union Republic constitutions, in many respects is a copy of the 1936 USSR Constitution, particularly in the articles describing the 
RSFSR's economic system. For example, Article 4 of the 1936 RSFSR Constitution states that "The economic system of the RSFSR is the socialist economic system and the socialist ownership of the means of production, established as the result of the liquidation of the capitalist economic system..."19 Article 4 of the RSFSR Constitution is exactly the same as Article 4 of the USSR Constitution with "RSFSR" replacing "USSR". Similarly, Articles 5 through 12 of the 1936 RSFSR Constitution are also copies of the respective articles in the USSR Constitution. The other Union Republic constitutions also copy these articles from the USSR Constitution. In the area of the RSFSR's political structure and the rights of the Russian Republic, Article 13 states "For the purpose of mutual economic and political cooperation as well as for defense, the Russian Soviet Federated Socialist Republic voluntarily united with the equal Soviet Socialist Republics." Article 13 then lists the other Union Republics in precisely the same order as they are listed in the USSR Constitution. All Soviet documents that list the Union Republics adhere to this order, which again reinforces the regional diversity thesis as the three Slavic republics are always listed first. Other relevant articles in this section of the 1936 RSFSR Constitution include Article 15: "The Russian Soviet Federative Socialist Republic retains its right to secede from the Union of Soviet Socialist Republics"; Article 16: "The territory of the RSFSR cannot be changed without the consent of the RSFSR"; Article 16a: "The Russian Soviet Federated Socialist Republic has the right to enter into direct relations with foreign states, to conclude agreements with them and to exchange diplomatic and consular representatives"; and Article 16b: "The Russian Soviet Federated Socialist Republic has the right to its own republic military formations." The rights delineated in Articles 15, 16, 16a and $16 \mathrm{~b}$ are common to all of the 1936 Union Republic constitutions and coincide with those rights afforded to the Union Republics by the USSR Constitution. 
Section IX of the 1936 RSFSR Constitution concerns the budgetary authority of the Russian Republic. Article 103 states "The state budget of the RSFSR is drafted by the RSFSR Council of Ministers and is then submitted to the RSFSR Supreme Soviet for approval." Absent from this section is any reference to the USSR budget, which will be changed in the 1978 RSFSR Constitution. Moreover, the 1936 RSFSR Constitution, like all of the Union Republic constitutions, makes no mention of the planned economy nor is there any reference to the Communist Party as the leading force in the republic's political, economic, or social system.

Obviously the language issue was a fundamental component of the overall nationality question in the Soviet Union. While the 1936 and 1977 USSR Constitutions did not address the language issue directly, the Union Republic constitutions did. And it is here that some curious differences existed in the various 1936 Union Republic constitutions, many of which will carry over to the 1978 constitutions.

To begin with, all of the 1936 Union Republic constitutions provided for the right of citizens to be educated in their native languages. For example, Article 125 of the 1936 RSFSR Constitution states "Citizens of the RSFSR have the right to an education" including "the ability to train in a school in the native language." The wording of the 1936 RSFSR Constitution concerning education and the right to receive an education in one's native language is exactly the same in all of the other Union Republic constitutions. Aside from this commonality, however, the 1936 Union Republic constitutions varied considerably on the language issue.

A key provision found in most of the Stalin-era Union Republic constitutions addressed the language in which the republics' laws would be published. In general, the Soviet Union can be divided into four broad regions on this particular aspect of the language issue. In the first region, the three Slavic republics of Russia, Ukraine, and Byelorussia, the constitutions are 
mixed. The constitutions of Russia and Ukraine, for example, contain no provision indicating in which language the republics' laws are to be published. But Article 25 of the 1936 Byelorussian Constitution indicates that "Laws passed by the BSSR Supreme Soviet shall be published in the Byelorussian and Russian languages over the signatures of the Chairman and the Secretary of the Presidium of the BSSR Supreme Soviet.”

The second region consists of the three Baltic Republics and Moldavia - all four republics were acquired in 1940 as a result of the Nazi-Soviet Non-Aggression Pact. Thus, all four constitutions were drafted at the same time and contain the same wording regarding the publication of laws. For example, Article 25 of the Estonian Constitution states "Laws passed by the Estonian SSR Supreme Soviet shall be published in the Estonian and Russian languages..." The exact same provision is found in Article 25 of the Latvian, Lithuanian and Moldavian constitutions as well.

The third region consists of the three Caucasian republics of Georgia, Armenia and Azerbaijan. In this region, the relevant provisions of the constitutions are a bit more detailed and they vary from one another. For example, Article 157 of the Georgian Constitution states "Laws as well as decrees and clarifications of the Georgian SSR Supreme Soviet and the regulations and orders of the Georgian SSR Council of Ministers shall be published in the Georgian language, but in the autonomous republics and autonomous oblasts in the Georgian language and in the language of the autonomous republic or oblast." No provision, then, is made for publishing laws in Russian in Georgia. However, the republics of Armenia and Azerbaijan do provide for publishing laws in the Russian language. Article 39 of the Armenian Constitution states that laws there are to be published in the Armenian, Russian and Azerbaijani languages 
whereas Article 41 of the Azerbaijani Constitution indicates that laws are to be published in Azerbaijani, Russian and Armenian.

The fourth region consists of Kazakhstan and the Central Asian republics of Uzbekistan, Turkmenistan, Tajikistan and Kirghizstan. The provisions regarding the publication of laws are far more varied and detailed in these republics than elsewhere in the Soviet Union, due to the more complicated demographic realities in this region. Article 25 of the Kazakh Constitution states that laws are to be published in the Kazakh and Russian languages. Article 41 of the Uzbek Constitution states that laws there "shall be published in the Uzbek and Russian languages, and in the Karakalpak ASSR in the Karakalpak language.” The Turkmen Constitution, in Article 39 states that laws in Turkmenistan shall be published in Turkmen, Russian, Uzbek and Kazakh. The Kirgiz Constitution provides for laws to be published in Kirgiz and Russian whereas Article 30 of the Tajik Constitution states that laws there "shall be published in the Tajik, Uzbek and Russian languages, but in the Murab and Dzhirgatal regions, in the Kirgiz language."

Thus, the Stalin-era Union Republic constitutions vary in terms of which language is to be used when publishing the laws of each respective republic. This diversity is a reflection of the lack of complete uniformity in the application of the Soviet Union's nationality policies and it will be maintained in the new 1978 Union Republic constitutions as well.

Language was also an issue regarding court proceedings in the Stalin-era Union Republic constitutions. It is here that language policies as reflected in the constitutions were especially tailored to the particular ethnic composition of each republic and therefore it is difficult to make any broad generalities. The only similarity in this provision is that each constitution provided for court proceedings to be held in the language of the titular nationality with guarantees made for 
the availability of translators for those who did not speak that particular language. Article 114 of the RSFSR Constitution, for example, states that "Legal proceedings in the RSFSR are conducted in the Russian language or in the language of the autonomous republic, or autonomous oblast, or national okrug, with provision for those who do not know this language to become fully acquainted with the materials of the case through translation, as well as the right to address the court in their native language." Article 114 of the RSFSR Constitution is similar to most of the other Union Republic constitutions in that it addresses the linguistic diversity of the republic and provides for court proceedings in certain regions to be conducted in the majority language of that region. Examples of these particularities include Article 97 of the Tajik Constitution which states "Judicial proceedings in the Tajik SSR are conducted in the Tajik language, but in regions with a majority Russian, Uzbek or Kirgiz population, then in the Russian, Uzbek or Kirgiz language.” Similarly, Article 109 of the Uzbek Constitution provides that "Judicial proceedings in the Uzbek SSR are conducted in the Uzbek language, in the KaraKalpak ASSR in the Karakalpak language, and in the rural areas and the urban areas with a majority Russian, Kazakh, Tajik, or Karakalpak population then in the Russian, Kazakh, Tajik, or Karakalpak language.” Likewise, Article 88 of the Turkmen Constitution states “Judicial proceedings in the Turkmen SSR are conducted in the Turkmen language, but in rural regions and in regional towns with a majority Russian or Uzbek or Kazakh population, then in the Russian, Uzbek, and Kazakh languages." The only republics that did not make specific provision for court proceedings to be conducted in a language other than that of the titular nationality are Ukraine, Estonia, Latvia, Lithuania and Byelorussia.

Another key difference regarding the language issue is that the three Caucasian republics of Georgia, Armenia, and Azerbaijan declared the language of the titular nationality as the 
official state language of the respective republic. For example, Article 156 of the Georgian Constitution states "The state language of the Georgian SSR is the Georgian language. National minorities living on the territory of the Georgian SSR are guaranteed the right to the free development and use of the native language as well as their culture and in state establishments." Article 119 of the Armenian Constitution and Article 151 of the Azerbaijani Constitution contain identical wording, only substituting Armenian or Azerbaijani as the state language. That these three republics were able to declare Georgian, Armenian, or Azerbaijani as the state language is an important example of these three republics retaining a certain degree of autonomy that was not available to the other Union Republics. Moreover, these three republics were able to include this provision into their constitutions likely because the strongest resistance to the Bolshevik Revolution occurred in these republics, especially in Georgia. As will be discussed below, efforts were made in 1977-78 to remove these articles from the Georgian, Armenian and Azerbaijani constitutions to bring them in line with the other Union Republics and as part of the overall effort by the Brezhnev leadership to consolidate more power at the center. Due to massive resistance in Georgia, however, the Brezhnev leadership failed to have these articles removed from the constitutions of the Caucasian republics.

A final important difference between the Stalin-era RSFSR Constitution and the constitutions of the other union republics appears in the article stating the republic's political basis. Article 2 of each Union Republic constitution outlines the political basis of the particular republic; the Preambles to the 1978 Union Republic constitutions will expand on these issues as will be discussed below. Article 2 of the RSFSR Constitution, for example, states "The political basis of the RSFSR is the Council of Workers' Deputies, which grew and became strong as a result of the overthrow of the landlords and capitalists and the establishment of the dictatorship 
of the proletariat." The RSFSR Constitution's Article 2 is the shortest of all of these. Article 2 of the other Union Republic constitutions contains more detail as to the establishment of Soviet power in each republic. In most of the republics' constitutions, Article 2 refers to the successful liberation of the titular nationality from the oppression of tsarism and of Russian imperialism. For example, Article 2 of the Ukrainian Constitution states "The political basis of the Ukrainian SSR is the Council of Worker's Deputies, which grew and became strong as the result of the overthrow of the capitalists and the conquest of the dictatorship of the proletariat, the liberation of the Ukrainian people from the national oppression of Tsarism and the Russian imperialist bourgeoisie and the defeat of nationalist counterrevolution." Article 2 of the Armenian Constitution contains the same language but adds "the defeat of the Dashnak nationalist counterrevolution and the conquest by the dictatorship of the proletariat." In similar fashion, Article 2 of the Uzbek Constitution also adds some local flavor by inserting "the overthrow from power of the landlords and capitalists, beys, emirs, and khans, through the conquest of the dictatorship of the proletariat, the reunification of the scattered parts of the Uzbek people in the state of the workers and farmers, the liberation of the Uzbek people from the national oppression of tsarism and the Russian imperialist bourgeoisie and the defeat of nationalist counterrevolution."

Thus, Article 2 in the majority of the Union Republic constitutions declares that the dictatorship of the proletariat ended the oppression of tsarism and of the Russian imperialist bourgeoisie and that it also prevailed over local nationalist counterrevolutionaries. The only exceptions to this is found in the constitutions of the RSFSR, Estonia, Latvia, Lithuania and Moldavia. Article 2 of the RSFSR constitution did not refer to Russian imperialist oppression for obvious reasons - the Soviet regime always admitted the imperialist nature of Tsarist Russia 
so therefore the Russians themselves were the imperialists in the former empire. But that the Estonian, Latvian, Lithuanian and Moldavian constitutions lacked the language regarding Russian tsarist and imperialist bourgeois oppression and the victory over local nationalist movements is interesting. Indeed, Article 2 in all four of these constitutions is identical; Article 2 of the Estonian Constitution, for example, merely states "The political basis of the Estonian SSR is the Council of Workers' Deputies, firmly established as a result of the overthrow of the capitalists and large landowners and the establishment of the dictatorship of the proletariat." The reason for this is simple: all four of these republics were either independent states (the three Baltic republics) between 1918 and 1940 or had been absorbed by a neighboring state after World War I, as was the case with Moldavia. Thus in theory, the dictatorship of the proletariat in these four republics did not end tsarist or Russian imperialist oppression.

As with the 1977 USSR Constitution, in general the 1978 Union Republic constitutions reflect the overall trend toward consolidating more authority at the center of the Soviet Empire at the expense of the Union Republics' sovereignty. The subtle erosion of Union Republic sovereignty in the 1978 constitutions is reflected in three broad areas: an emphasis on the role of the CPSU in Soviet life; references to the USSR as an integral unit both economically and in terms of nationality; and finally slight references to the rights retained by the Union Republics in international relations, a topic which was discussed above in the section analyzing the USSR Constitution. Yet despite this overall trend toward reducing Union Republic sovereignty, the differences found among the various Union Republic 1978 constitutions reveals some resistance to this trend as well as a continuation of the rhetoric praising the Russian people as a helpful elder brother which had become so pervasive in the Brezhnev era. Thus, we see in the 1978 Union Republic constitutions a compromise between the centralizing tendency of the Kremlin 
and the efforts at the Union Republic level to retain their traditional (in a purely constitutional sense of the term) sovereignty.

Like the Stalin-era Union Republic constitutions, the 1978 Union Republic constitutions are very similar to one another, often using the same wording for many of the articles. Therefore, as with the above analysis of the Stalin-era constitutions, I will use the 1978 RSFSR Constitution as a model to highlight the similarities found in all fifteen of the Union Republic constitutions. Then I will analyze the differences by making reference to several of the Union Republic constitutions.

First, the 1978 Union Republic constitutions reflect the 1977 USSR Constitution's general trend toward consolidating additional authority at the center. Article 6 of the RSFSR Constitution states "The leading and guiding force of Soviet society, the core of its political system, its state and its social organizations is the Communist Party of the Soviet Union." In addition to this, Article 3 declares "The organization and activity of the Soviet state are built in accordance with the principles of democratic centralism..." Both of these provisions, it will be remembered, are also found in the 1977 USSR Constitution. To be sure, the CPSU had been functioning as the core body in the Soviet political system long before the adoption of the 1977 USSR Constitution, so these provisions in the federal and Union Republic constitutions are merely stating the reality. But that the Stalin-era constitutions did not explicitly state the role of the Party in Soviet political life is important in that the Brezhnev leadership in 1977-78 is enshrining into Soviet constitutional law the CPSU's monopoly on power and the doctrine of democratic centralism. Therefore, the 1977-78 constitutions changed Soviet constitutional law to provide an even greater basis for the Party's monopoly role in political life and the doctrine of democratic socialism, which indirectly means the further concentration of power at the center of 
the Soviet Empire due to the highly centralized structure of the CPSU and due to the fact that the various republic Communist Parties functioned merely as branches of the CPSU. Moreover, the enhanced role given to the CPSU in Soviet life by the new constitutions is another reflection of the doctrine of Developed Socialism. Official statements regarding Developed Socialism stressed the increased role of the Communist Party in a society of mature socialism. Articles 6 and 3 of the 1978 RSFSR Constitution and their equivalents in the other Union Republic constitutions and in the federal constitution, then, are subtle attempts to provide a constitutional legal basis for the Brezhnev leadership's ongoing efforts to concentrate more power at the center.

The general trend toward centralization is best revealed in the Union Republic constitutions' articles regarding economic affairs and the state budget of each republic. All Union Republic constitutions contain the same language regarding these issues, so again the RSFSR Constitution will serve as the model. Article 152 of the 1978 RSFSR Constitution states "The state plan of economic and social development of the RSFSR is an integral part of the state plan of economic and social development of the USSR" [emphasis added]. Moreover, Article 152 explains that "Current and future state plans of economic and social development of the RSFSR are intended to provide an integrated economic and social development on the territory of the republic in accordance with the basic goals and directives of the economic and social development of the USSR." Article 154 adds that "The state plan of the economic and social development of the RSFSR is drafted by the RSFSR Council of Ministers based on the state plan of economic and social development of the USSR..." [emphasis added]. These two articles are also found in the other Union Republic constitutions.

Articles 152 and 154 of the 1978 RSFSR Constitution and their equivalents in the other Union Republic constitutions are significant for two reasons: first, it is the first time that state 
economic planning is mentioned in Union Republic constitutions; the Stalin-era constitutions both republic and federal - were silent on the issue of state planning. Secondly, and more importantly, Articles 152 and 154 explicitly state that the RSFSR state plan is simply a component of the overall USSR state plan; a provision that applies to all of the Union Republics. Just as Articles 152 and 154 place the RSFSR state plan within the USSR state plan, Articles 158 and 161 of the 1978 RSFSR Constitution place the Russian Republic's budget within the overall USSR budget. Article 158 stipulates that "The state budget of the RSFSR is an integral part of the USSR federal state budget." Article 161 adds that "The state budget of the RSFSR is drafted by the RSFSR Council of Ministers based on the state plans of economic and social development of the USSR and the RSFSR, and the state budget of the USSR..." The provisions found in Articles 158 and 161 are not found in the Stalin-era constitutions. Indeed, the Stalin-era Union Republic constitutions make no reference to the USSR state budget and thus imply that the republic budgets are independent of the federal budget, which is more akin to the principles of federalism. That the 1978 Union Republic constitutions make it clear that the republic budgets are based on the USSR state budget is again a subtle erosion of the republics' sovereignty and thus changes the constitutional basis of Soviet federalism. This provision is also again in keeping with the precepts of Developed Socialism as it continues the integration of the Soviet Union into a single economic complex.

The most significant change to the 1978 republic constitutions is one that was proposed, but did not become enshrined in the final version. In 1977-78, it was proposed to remove the articles from the Georgian, Armenian, and Azerbaijani constitutions declaring Georgian, Armenian and Azerbaijani as the official languages of each respective republic. P.G. Pikhoia notes that when the all-Union and republic constitutions were discussed in the CPSU Politburo, 
"discussions of the new [USSR] constitution and the acceptance on its basis of new constitutions in the union republics unexpectedly ran into serious problems. The newly-accepted USSR Constitution lacked anything on a state language. This corresponded with the theoretical premise on the rapprochement of nations and nationalities in the USSR and the 'establishment of a new community - the Soviet people"” Pikhoia adds that when it was proposed to remove the statelanguage articles from the Georgian, Armenian, and Azerbaijani constitutions, CPSU Central Committee members Boris Ponomarev, Konstantin Chernenko (who would eventually succeed Yuri Andropov as CPSU General Secretary in 1984), I.V. Kapitonov, and M.V. Zimianin drafted a letter to the CPSU Central Committee observing "It is possible that the removal from the constitutions of the Trans-Caucasian republics, particularly Georgia and Armenia, of the articles on state language, which have been in those constitutions since the first days of Soviet power, may cause a negative response from certain parts of the population, as well as in the international arena. Wariness [nastorozhennost'] of this issue has been expressed in discussions in the CC CPSU and in the leadership of the various republics." ${ }^{20}$ As it turned out, drafts of these constitutions did remove the state-language articles, prompting protest. On April 14, 1978, five thousand people took to the streets in Tbilisi, Georgia, as the Georgian Supreme Soviet met to discuss the proposed changes. Recently-installed Georgian First Secretary Eduard Shevardnadze then announced to the demonstrators that the proposed changes would be revoked; the Georgian language would remain the state language of the Georgian SSR. ${ }^{21}$ Similar proposed changes to the Armenian and Azerbaijani constitutions failed as well.

The new USSR Constitution and its accompanying Union Republic constitutions represent Brezhnev's most significant contribution to the evolution of the Soviet system. These documents enshrined into the Soviet Union's fundamental laws the tenets of Developed 
Socialism. The USSR Constitution officially declared the Soviet Union to be a state of mature socialism and the articles contained therein effectively eroded the republics' de jure sovereignty in the name of Developed Socialism. With the ratification of the USSR Constitution, Brezhnev successfully elevated the Soviet Union to a new stage of socialist development characterized by the delineation of the USSR into a single economic complex, the ongoing rapprochement of nations, the coming of the new Soviet people, and thus overall, a legal consolidation of the Soviet Empire. Yet, as has been indicated, the forces of consolidation met with some resistance. Interior Minister Shchelokov opposed language that seemed to favor the Russians over the nonRussians, Moldavian First Secretary Il'iashenko proposed allowing the republics to have greater control on the appointment of republic procurators. Most significantly, the attempts to remove the articles establishing state languages in the Caucasian Republics failed in the face of popular protest. Thus, while the extremes of Developed Socialism failed to find their way into the new constitutions, the essential principles of Developed Socialism - particularly the focus on increasing the unity of the Soviet Union - did find their way into the new constitutions. Yet, as will be discussed below, while the ratifications of new constitutions can be considered an overall success for Brezhnev and his theory of Developed Socialism, Developed Socialism as it was applied to the nationality issue had only mixed results due to a variety of factors that prevented a complete consolidation of the Soviet Empire. 


\section{CHAPTER SIX}

\section{DEVELOPED SOCIALISM AS SECOND COLONIAL OCCUPATION}

The policies of Developed Socialism resulted in the further concentration of power in Moscow at the expense of the union republics which was manifested particularly in the new USSR Constitution of 1977 and the Union Republic constitutions ratified in 1978. The Brezhnev leadership's continued rhetoric regarding the rapprochement of nations and the use of Russian as the lingua franca of the Soviet Union reinforced the imperialist nature of Brezhnev's approach to the Soviet nationality question. But Developed Socialism also resembled the post-World War II second colonial occupation that took place in parts of the British and French empires. This chapter will evaluate Developed Socialism as the Soviet Union's second colonial occupation. The tenets of Developed Socialism and the initiation of grandiose construction projects such as the Baikal-Amur Mainline Railway indicate the revival of imperial power in the Soviet periphery, particularly in Central Asia similar to what took place in Britain's colonies in East Africa after World War II.

This chapter will also assess the resurgence of underground Islam in the Central Asian republics and the Brezhnev leadership's continued reliance upon Developed Socialism to deal with this issue. The Brezhnev leadership attempted to contain Islam through propaganda that continued to emphasize the rapprochement of nations as the panacea that will eventually eradicate the dangers posed by Islam and religion overall. But the Brezhnev leadership failed to appreciate that the resurgence of underground Islam was not purely a nationality issue - instead it was a movement that transcended nationality and it contained the roots of radical Islam that came to the surface under Gorbachev and triggered violence in Central Asia after the collapse of 
the Soviet Union. Moreover, foreign policy concerns, especially the Soviet Union's interests in the Middle East, the invasion of Afghanistan and the Iranian Revolution hampered serious efforts to crackdown on this resurgent Islam.

Finally, this chapter will assess the success and effectiveness of Developed Socialism as an imperial strategy. This section will show that while Developed Socialism was firmly rooted in Leninist ideology, it failed to consolidate the Soviet Empire to the degree intended by the Brezhnev leadership because other factors such as Brezhnev's reluctance to replace republic Party leaders prevented a complete consolidation of imperial power at the center.

It may be argued that the Soviet Union itself was a continuation of the former tsarist Russian Empire and that the entire period of the Soviet Union's existence constitutes a second colonial occupation. I disagree with this assessment. After the October Revolution and the ensuing Civil War, several parts of the former tsarist empire gained independence such as Finland, Estonia, Latvia, Lithuania, and Poland. Meanwhile, western Ukraine was transferred to Poland and Czechoslovakia while Bessarabia was attached to Romania. Other parts of the former tsarist empire such as Ukraine and Georgia, Armenia and Azerbaijan briefly declared independence before succumbing to Bolshevik rule. Richard Pipes and other historians who have written about the Soviet nationality question refer to the disintegration of the former tsarist empire, thereby implying that the former tsarist empire ended and the Soviet Union was a new entity. I agree with this assessment. Although influenced greatly by the tsarist imperial legacy, particularly after Stalin removed nationality policy from the center of the CPSU platform in 1938 and his rehabilitation of tsarist Russia during the same period, the Soviet Union was a separate imperial entity. The Soviet Union had a completely different political structure than the former tsarist empire, was based on a radically different ideology in the form of Marxism-Leninism, and 
it transformed the economic system, among other differences. Thus, as will be discussed in this chapter, the tenets of Developed Socialism along with Brezhnev's attempts to modernize further the economy through grandiose projects such as BAM represent the Soviet Empire's second colonial occupation.

\section{Developed Socialism - The USSR's Second Colonial Occupation}

As stated in Chapter One, after World War II, British policies in Africa and Malaya sought to reform colonial rule in these parts of the empire through a process that has been termed the second colonial occupation. This reinvigoration of empire in Africa and Malaya involved, among other things, grandiose development schemes such as the groundnut scheme in Tanganyika and efforts to modernize local colonial administrations. These efforts failed and instead resulted in renewed opposition to British rule, thus furthering the development of the decolonization process. Brezhnev's policies in the Soviet Union resemble Britain's second colonial occupation, albeit with some important differences. This section will first discuss the primary components of Britain's second colonial occupation and then it will draw parallels with policies and schemes undertaken by the Brezhnev leadership such as the Baikal-Amur Railway Project (BAM), efforts to increase cotton production in Uzbekistan which contributed to growing corruption there, and the tenets of Developed Socialism itself that, as has been highlighted in this chapter, represent a tightening of control of the Soviet periphery in ways similar to the second colonial occupation. In both the British colonies and in the Soviet Union, their respective second colonial occupations provoked continued nationalist unrest thereby furthering the development of the decolonization process in both cases. 
As was discussed in Chapter One, Britain turned to what remained of its empire in the late 1940s to help solve Britain's economic troubles and embarked on a last-ditch effort to maintain its empire in Africa and Malaya. These efforts involved such things as large-scale agrarian reforms to make the African colonies more profitable which itself necessitated a deeper involvement of colonial administrations in local agriculture. Indeed, in the late 1940s, "the colonial state would move on an unprecedented scale to act as the prime agent of agrarian change and rural development in Africa and elsewhere." By 1955, the Colonial Office listed more than "seventy major agricultural development initiatives" that included such activities as water and soil conservation and "resettlement schemes". ${ }^{1}$ The best known, and most disastrous, of these initiatives was the groundnut scheme in East Africa begun in 1947.

The East Africa Groundnut Scheme ${ }^{2}$ envisioned the clearing of over 3 million acres of land by 1952 which were expected to yield 600,000 to 800,000 tons of groundnuts each year. The scheme’s cost was estimated at $£ 24$ million with another $£ 1.25$ million allocated for a railroad and a port. Above all, as Hodge explains, "every aspect of the plan was to be fully mechanized (something unheard of before the war), from the initial bush-clearing to the plowing and planting to the lifting and harvesting of the nuts, involving a literal invasion of bulldozers and tractors and an army of African wage labor ..." Ultimately, this was to be "a showcase of what science, technology, and the state could achieve, and it all had to happen in record-breaking time in order to produce export food surpluses to help support Britain's postwar economic recovery." The East Africa Groundnut Scheme, then, resembles earlier and contemporary Soviet projects to tackle nature with science and manpower, such as Khrushchev's Virgin Lands Program. 
Ultimately, environmental and soil conditions doomed the East Africa Groundnut Scheme to failure. As Hodge explains, "the crux of the problem was that the project was premised on an entirely new approach that had never before been tried in British tropical Africa: large-scale, mechanized production of crops." In addition, the Groundnut Scheme's planners' zeal to accomplish what was theoretically possible in such a short amount of time led to inadequate planning, thus contributing to the disaster. ${ }^{3}$

In addition to the Groundnut Scheme, the Tanganyikan government at the behest of Britain, embarked on the Sukumaland Scheme which aimed at improving living standards and preventing soil exhaustion through an elaborate resettlement program. Launched in 1947, the Sukumaland Scheme called for "reducing pressures on the overcrowded and over-cultivated central areas through the opening up of previously uninhabited or under-inhabited parts to the west, east, and south, and subsequently through the adoption of improved methods of husbandry and soil conservation over the whole region."4 Moreover, farmers were to be allocated landholdings according to the Sukumaland Equation, "which was used to determine the 'ideal' human and stock population density as well as the volume of water that was needed at each watering point." This meant about twenty acres for each farming family. ${ }^{5}$

Like the Groundnut Scheme, the Sukumaland Scheme also failed by 1955 due in large measure to bureaucratic and staffing problems. Yet, as Hodge explains, "the most intractable barrier to the scheme's success was the increasing lack of cooperation of the people for whom it was intended." Farmers rejected the new farming techniques introduced under the scheme and they bitterly resented the innumerable livestock regulations imposed by the government, so much so that by 1953 , "the scheme came to resemble a police operation more than an agricultural assistance program." Ultimately, the failed Sukumaland Scheme fostered the growth of 
"antigovernment sentiment that would spread throughout the territory in the mid-1950s - and enable incipient nationalist leaders to gather mass rural support for independence" thereby "helping to precipitate Tanganyika's early achievement of independence."6 Britain's second colonial occupation in East Africa, then, with its focus on modernizing agriculture and grandiose plans, triggered anti-colonial dissent in Tanganyika and thus spurred the decolonization process there.

The Soviet Union under Brezhnev also had its grandiose projects that continued the Soviet tradition of tackling nature through science and the mass mobilization of human labor such as the White Sea Canal project under Stalin and Khrushchev's Virgin Lands Program, among many others. Brezhnev's pet project was the construction of the Baikal-Amur Mainline Railway (BAM) which blazed a trail across over two thousand miles of Siberian tundra. Begun in 1974, BAM was touted by the Brezhnev leadership as "an epic victory of humankind over nature, a forum for ethnic cooperation, and a catalyst for the economic development of the USSR's eastern reaches ..."7 Like the Groundnut Scheme, BAM sought to use modern science and technology to open the barren stretches of Siberia for economic development, primarily through the exploitation of Siberia's vast mineral resources. Moreover, the Brezhnev leadership "undertook BAM to ease tensions among a number of potentially disaffected groups, including youth, members of minority ethnic populations, and women. BAM was to be the thread that would bind these loose elements of Soviet society into a tightly knit cloth that would ensure the Soviet Union's long-term survival." ${ }^{\prime 8}$ In this respect, then, BAM represents one element of the Soviet Union's second colonial occupation experience in that it was a massive project to open up and modernize the vast expanses of Siberia and, more particularly, it was a re-assertion of Soviet 
imperial strategies with its focus on promoting the ethnic cohesion of the Soviet Union albeit under Russian leadership.

At its height, the BAM project employed at least 500,000 workers along its route with workers coming from all corners of the Soviet Union. As Christopher Ward argues in his book that examines the BAM project, "Soviet officialdom was keenly aware of the potentially disastrous consequences of ethnic tension within the railway's population and, by extension, throughout the USSR. Through its propaganda network, the state consistently proclaimed the BAM project to be a forum where the center's claims to multinationalism and ethnic equality were visible."9 Yet, as Ward points out, BAM coverage in the Soviet press touted "Russian might" in the massive size and power of the construction equipment used along the railway's route. Moreover, Slavic labor formations assumed the leadership role along the route while nonSlavic laborers were relegated to menial tasks. Thus, according to Ward, "The complex and often divisive factor of nationality contributed to BAM's ultimate failure to realize one of its main goals: namely, the improvement of relations between on the one hand ethnic Russians and other Slavs who labored on the 'path to the future' (that is, the 'majority') and the Soviet Union's non-Slavic nationalities ..."10 Despite massive amounts of propaganda heralding the multinational cohesion of the BAM labor force, in reality non-Slavic labor brigades often could not recruit enough workers to fulfill their quotas, were plagued by high rates of desertion, and they suffered from the discriminatory practices of the Slavic labor brigades and of the Komsomol itself which was in charge of the BAM project. Ward concludes that "As a result of this deliberate policy of segregation and marginalization of non-Slavic BAMers, the national tensions that BAM was supposed to ameliorate in fact grew more divisive throughout the USSR.",11 BAM did not fail to the degree of the Groundnut Scheme; it was finally completed in 1984 but at 
enormous cost and it never lived up to its primary goal of opening Siberia to tremendous levels of development. But it did serve to exacerbate ethnic tensions in the USSR and created further resentment among non-Slavs toward Soviet imperial practices similar to the ways in which the Sukumaland Scheme provoked anti-colonial sentiments in Tanganyika.

Large-scale projects also provoked nationalist sentiments in Uzbekistan. Here, Moscow's push to increase cotton production caused rampant corruption in the Uzbek Party, severe environmental damage, and growing nationalist discontent. Irrigation projects to bring water from the Amu Dar'ya and Syr Dar'ya rivers to Uzbekistan's growing cotton fields led to the shrinking of the Aral Sea, which provoked nationalist outrage. Irrigation had been practiced on these two rivers for millennia, but increased dramatically after 1960. More than three million hectares of land in the Aral Sea basin had been irrigated by 1900. In 1960, this irrigated area had grown to five million hectares and by 1980 it had grown to 6.5 million hectares. Irrigation accounted for 91\% of all water withdrawal from the Amu Dar'ya and Syr Dar'ya rivers by 1980. As a result of irrigation projects diverting water from the Amu Dar'ya and Syr Dar'ya rivers as well as periodic droughts in the Aral Sea basin, the Aral Sea's area shrank by $40 \%$ between 1960 and 1987 and the sea's volume fell by $66 \% .^{12}$

As a result of irrigation and the overuse of land for cotton cultivation, "The water level of the Aral Sea fell by fourteen meters between 1959 and 1989, leaving behind immense salt flats. Wind blown salt decreased the fertility of the already damaged soil and infiltrated the food chain to the point where the salt content in the milk of nursing mothers in the Aral region was several times higher than normal.” Many Uzbeks began blaming the Russians for the environmental degradation of their republic as well as for the lack of consumer goods available in Uzbekistan. Uzbek nationalist activities were on the rise from the late 1960s into the 1970s. In 1978, "a new 
chemical factory in Chirchik and a theater in Tashkent were blown up, apparently as a protest against Moscow." Moreover, "Placards reading 'Russians Go Home' began to appear at public rallies, while native shopkeepers began to refuse to sell to Russian shoppers. Uzbek newspapers took a growing interest in the Islamic religion ..."13 Clearly, Moscow's renewed push to increase cotton production in Uzbekistan aroused Uzbek nationalism and thus this aspect of the Soviet Union's second colonial occupation resulted in the development of the decolonization process in Uzbekistan.

But it was not until after Brezhnev's death that Moscow's second colonial occupation in Uzbekistan came to fruition. Beginning under Andropov's leadership, Moscow purged the Uzbek leadership due to the rampant corruption that took hold while Rashidov was still alive (he died in October 1983), the most egregious of which was the falsifying of cotton production numbers. According to John Staples who studied the purge in Uzbekistan, by 1986 there had been a significant increase in the number of Slavs holding top positions within the Uzbek Party. But Staples argues that Moscow's tightening of control in Uzbekistan actually began late in Brezhnev's tenure. He argues that the Uzbek leadership's "failure to increase or even maintain levels of economic output, their inability to deal with increasing manifestations of Uzbek nationalism, and their failure to deal with Moscow's demographic plans had all come to the attention of Brezhnev and his lieutenants, and there is ample evidence that the corruption purges were a part of the Kremlin's plans well before Andropov had an opportunity to intervene."14

If Brezhnev had indeed been planning to purge the Uzbek leadership before his death, then it would seem to indicate that the Brezhnev leadership did not really treat the Central Asian republics differently than the western republics as I have argued throughout this study. It is true that Moscow did attempt to tighten control over Uzbekistan, but not to the degree to which it 
tightened control over Ukraine. In Uzbekistan, Moscow was primarily concerned with economic output. As Staples suggests, so long as the Uzbek leadership increased (at least on paper) economic output, then Moscow could tolerate Rashidov's own toleration of increasing manifestations of Uzbek nationalism. Conversely, Shelest's reluctance to crack down on Ukrainian nationalism to Moscow's satisfaction could not be tolerated, regardless of Ukraine's economic performance. Thus, differences still existed on Moscow's policies toward its western republics and its Central Asian republics. And finally, Gorbachev's purge in Uzbekistan, which Andropov had started, represents a second colonial occupation in that republic as Moscow installed officials who were far more reliable.

Finally, the tenets of Developed Socialism and their focus on enhancing the unity of the Soviet Union represent a second colonial occupation in the non-Russian republics. Just as Britain sought to reassert its imperial control in Africa and in Malaya, the Soviet Union under Brezhnev reasserted Moscow's control over the republics but with varying degrees of success. As discussed in Chapter Five, the 1977 USSR Constitution eroded republic sovereignty and thus symbolized the center's tightening control over the periphery. In addition, the Brezhnev leadership's emphasis on the Soviet Union forming a single economic unit also symbolized a further concentration of power in Moscow at the expense of the republics. These policies in addition to Moscow's promotion of the Russian language provoked manifestations of nationalism in Ukraine, demonstrations of a national character in Georgia, and nationalist activities in Uzbekistan. Moscow's second colonial occupation, therefore, helped to further the decolonization process in the Soviet Empire in ways that resemble the experiences of Britain in her African colonies after World War II. 


\section{Confronting Radical Islam - The Final Phase of Brezhnev's Anti-Imperialist Empire}

Just as the Brezhnev leadership faced a developing decolonization process in the 1970s and growing manifestations of nationalism, it also was confronted by the growth of underground Islam and the beginnings of a radical Islamic movement that came to the surface in the 1980s and 1990s. By the late 1970s, the growth of underground Islam particularly in the Central Asian republics posed a challenge to the Brezhnev leadership and to the policies of Developed Socialism. The growth of underground Islam in Soviet Central Asia was similar to the familiar challenges posed by nationalism yet it was fundamentally different in that Islamic revival was not purely nationalistic in nature. Rather, it was trans-national as it attracted followers across Central Asia, particularly in Uzbekistan and Tajikistan. This section will discuss the overall Soviet strategy for containing Islam and more specifically, the Brezhnev leadership's policy for dealing with the growing challenge posed by Islam. Moscow's approach to the developing problem of Islamic revival was hampered by foreign policy and by its continued reliance on pursuing the policies of Developed Socialism which meant that Moscow treated the Islamic challenge more as a nationality issue rather than a trans-national religious movement.

Unlike the Russian Orthodox Church, the Soviet government was never able to co-opt Islam completely in the Soviet Union due in large part to Islam's inherently decentralized nature. However, in 1943, the Soviet government established the Spiritual Administration of the Muslims of Central Asia (SADUM) and delegated to it "the management of religious matters among the Muslims of Central Asia and satisfying their needs in religious issues" and “delegating representatives to the union republics to satisfy believers' needs and establish a leadership for mosques in the more distant areas of those republics." ${ }^{15}$ In the following decades, SADUM established ten mosques and two madrassas, one in Bukhara in 1945 and another one in 
Tashkent in 1971. ${ }^{16}$ Through SADUM, the Soviet government sought to control Muslim clergy and to maintain strict oversight of Islamic activity in Central Asia. SADUM, then, also represented officially sanctioned Islam in Soviet Central Asia.

However, despite severe crackdowns on religion across the Soviet Union dating to the 1920s and the establishment of "official Islam" through SADUM in 1943, unofficial mosques and clerics continued to operate underground. Martha Brill Olcott, one of the leading scholars of Islam in the Soviet Union, argues that Khrushchev's active foreign policy in the Middle East allowed for SADUM officials to study at Islamic schools in the Middle East and also encouraged Muslims from the Middle East and Africa to visit the Soviet Union. As a result, according to Olcott, spiritual literature from the Middle East, particularly from Saudi Arabia, began to be disseminated in Soviet Central Asia which fostered the further development of unofficial, underground Islam. Olcott further explains that even Soviet diplomatic officials from Central Asia who were not connected with SADUM were sent to the Middle East to study Arabic and that these officials also brought back spiritual literature. In addition, Olcott states "The Saudis, in particular, during all their visits donated literature to the library of SADUM, literature that seems to have been freely available to all those with access to this library."17 Such literature included the works of Sayyid Qutb, a prominent radical Egyptian cleric who had been executed by the Nasser regime and who is also regarded as one of the primary ideological influences on later jihadists such as Osama bin Laden.

By the 1970s, then, two forms of Islam existed in Central Asia: the officially sanctioned Islam controlled by SADUM and a growing underground Islamic movement. It was the underground Islam that attracted the attention of Moscow because of its potentially anti-Soviet 
message. It is also from this underground Islam that radical Islam began to emerge in the late 1970s and rose to the surface in the 1980s and 1990s.

Since the establishment of Soviet power in Central Asia in the early 1920s, underground Islam existed largely through the formation of clandestine study groups led by prominent Islamic scholars. In the 1970s, two clerics in Uzbekistan, Muhammadjan Hindustani and Hakimjon qori Vasiev Margilan attracted a sizeable following of students from throughout Central Asia. Born in 1892, Hindustani studied at madrassas in Kokand and Bukhara before the October Revolution and then he fled to Afghanistan and later pursued further Islamic study in India. He returned to the Kokand region in 1929 and was twice arrested in the 1930s during the Stalin purges. Hindustani was rehabilitated after Stalin's death and he began teaching Urdu at the Institute of Oriental Studies in the Academy of Sciences at Dushanbe. At this time, Hindustani "began offering illegal religious instruction ... with the tacit approval of some local authorities.",18

Fluent in seven languages, Hindustani offered his students a broad curriculum including the Quran, exegesis of the Quran, Arabic language and syntax, the Hadith, Islamic cosmology, Islamic medicine and Islamic astronomy. ${ }^{19}$ Hindustani's reputation as an Islamic scholar grew through the 1960s and 1970s so that by the early 1980s his lectures were widely circulated on audio cassette throughout Central Asia. But although Hindustani's school was illegal (yet he was well-known by local authorities), his teachings were not political. He rejected the politicization of Islam which angered many of his more radical students.

Like Hindustani, Hakimjon qori Vasiev Margilan was also a prominent Islamic cleric who taught illegally in Central Asia in the 1960s and 1970s. Margilan had been one of Hindustani's students but he left Hindustani's school over doctrinal disputes. Margilan objected to Hindustani's refusal to politicize Islam; he once remarked of Hindustani "Mullah 
Muhammadjan [Hindustani] is like a poplar in the field ... He blows in the direction of the wind." ${ }^{20}$ The dispute between Hindustani and Margilan was a reflection of a developing rift within underground Islam in Central Asia. Most Muslims in Central Asia had for centuries adhered to the Hanafi school of Islamic thought and jurisprudence that "accepted the idea that Muslims could be ruled by someone who was either a ghayr-i din (nonbeliever) or a kafir (infidel) so long as the leader allowed mosques and madrassas to remain open, allowed Muslims to observe their rituals, and allowed Muslims to be judged by Sharia law." ${ }^{21}$ The Hanafi school, then, was more amenable to Soviet rule than more conservative strains of Islamic thought. However, in the $19^{\text {th }}$ and $20^{\text {th }}$ centuries, the Salafi school of Islamic thought gained some adherents in Central Asia. The Salafi is a more conservative school of thought that only accepts the teachings of Islam dating to the first four caliphs. The dispute between Hindustani and his former student Margilan was a reflection of the differences between the Hanafi and the Salafi. Hindustani was of the Hanafi school, while Margilan was more sympathetic to the Salafi.

Despite the doctrinal dispute between Hindustani and Margilan, students of both clerics grew more radical in the 1970 s as they sought to politicize Islam. It is at this point that both Olcott and Vitaly Naumkin argue that the roots of radical Islam in Central Asia began to appear. Naumkin states that Hindustani was very critical of his former students who, in Hindustani's opinion, were furthering the split between Hanafi and Salafi Islam in Central Asia. Hindustani called his more radical students "Wahhabis" and argued that their Salafi leanings had "been imported from abroad and thus incompatible with Central Asian Hanafi Islam.” Indeed, some of Hindustani's students accused him of collaborating with the Soviet authorities and implied that he was a KGB informant. ${ }^{22}$ Both Naumkin and Olcott argue that this Hanafi-Salafi schism that 
began in the 1970s led to the politicization of Islam in Central Asia in the 1980s and ultimately to the formation of Islamist parties in Uzbekistan and Tajikistan in the 1990s.

It appears that Soviet authorities were aware of at least the revival of Islam in Central Asia as well as in other Muslim regions of the USSR, but it remains unclear whether they understood fully the growing influence of the more fundamentalist Salafi movement in Central Asia. Yaacov Ro'i states that as early as the 1960s the KGB in Tajikistan received reports “on trends and developments within the republic's Muslim community" but "it is not clear whether the danger was thought to be internal, given the vitality of Islam in Tajikistan and the physical inaccessibility of so many of its strongholds, or to have emanated from neighboring Afghanistan, in view of the vulnerability of considerable sections of the border." Moreover, in the Nakhichevan ASSR within Azerbaijan, "the KGB was blatantly concerned about the infiltration of Islamic influences from Iran, at least as of the early 1970s. It reported the persistent religious propaganda being broadcast by Iranian radio stations [and] inscriptions of a religious content which appeared on the hills in Iranian territory and were clearly visible on the Soviet side ..." By 1980 in the aftermath of the Iranian Revolution and the Soviet invasion of Afghanistan, the head of the KGB in Azerbaijan wrote "In connection with the situation in Iran and Afghanistan, the US special services are trying to use the Islamic religion as one of the factors in influencing the political situation in our country, especially in places with a Muslim population.,23

All-union and republic officials then were aware of the revival of Islam throughout the Muslim regions of the USSR, but it is uncertain as to how well they understood the revival. While local officials in Uzbekistan or Tajikistan knew of the illegal schools run by clerics such as Hindustani and therefore likely were aware of the more radical element developing among the students of those schools, it is unclear whether or not Moscow was aware of the growing radical 
influence. It is clear, however, that the Brezhnev leadership applied the principles of Developed Socialism to try to contain the revival of Islam. Soviet literature from the 1970s and official speeches in the late 1970s and early 1980s reveal that Moscow took a conciliatory tone toward Islam and sought to combat the revival of Islam with propaganda and the continuing insistence that the rapprochement of nations will ultimately solve the problem of Islam as well. The Brezhnev leadership, then, equated the revival of Islam with manifestations of nationalism. The cure for both was increased propaganda, enhancing internationalist education, and the further rapprochement of peoples. However, foreign policy concerns weakened the Brezhnev leadership's efforts to contain the revival of Islam.

Reflecting the Brezhnev leadership's strategy for dealing with the revival of Islam, N. Ashirov published a book in 1975 entitled Islam i Natsii in which Ashirov assesses Islam's relationship with the development of modern nations. The first half of Ashirov's book is a treatise on Developed Socialism and seems to have been written for a domestic Soviet audience. For example, Ashirov writes, "It is through the fraternal friendship and the international mutual assistance of the socialist nations of the peoples of the Soviet East that they stepped out of patriarchal-feudal society, bypassing the capitalist stage and into socialist society." Ashirov then quotes Mufti Ziautdin-khana ibn Ishana Babakhana's address on the occasion of the $50^{\text {th }}$ Anniversary of the formation of the USSR, who stated "Thanks to the fraternal relations and friendly cooperation and mutual assistance of the peoples of the Soviet Union, the Muslims of our country in a short historical time achieved colossal successes in all aspects of life and at the present time rightly consider themselves a fully developed, modern nation with all of the attributes of industrial, social, scientific and cultural progress." Ashirov adds that Muslims in the Soviet Union often credit Allah for fostering the unity and friendship of the nations of the Soviet 
Union, which, according to Ashirov, is a grave error on the part of Soviet Muslims. Rather, it is the Communist Party that has fostered the development of the unity and friendship of the USSR's diverse peoples. Moreover, Ashirov writes, “Islam, like any other religion, prevents the rapprochement [sblizhenie] of peoples and the unity and mutual-assistance of the workers of the various nationalities by the fact that it misconstrues the issues related to the emergence of nations, their essence and national relations. It identifies the national community with religion, it supports the nation's most conservative reactionary elements which speak out against the rapprochement of peoples and against the mutual enrichment of national cultures." As evidence for Islam's impediment to the rapprochement of nations, Ashirov asserts the claim that "some tribal remnants continue to exist. One of the factors that continues their existence is the Muslim religion. In a number of regions of the Turkmen, Kirgiz, and Kazakh SSRs, there are still cases where clergy inspire believers with the idea that Allah 'counts' only those rituals carried out by representatives of their clan." According to Ashirov, "Such actions by Muslim clergy contribute to the continuation of clan-tribal remnants, causing harm to the strengthening of the unity of the socialist nations of the Soviet East, and consequently cause harm to the further strengthening of the unity and friendship of all Soviet peoples." 24 Ashirov is asserting the argument, then, that the doctrines and teachings of Islam impede the process of the rapprochement of nations within the Soviet Union and thus run counter to the principles of Developed Socialism.

Ashirov's depiction of Islam as detrimental to the rapprochement of nations is not surprising, of course. What is striking, however, is that Ashirov appears to aim the second half of his work at Muslim readers outside the Soviet Union. He begins with an attack on "bourgeois propaganda" which, according to Ashirov, "seeks to disorient global public opinion on the position of religion and believers in the USSR, and thus tarnish the theory of scientific socialism 
and socialist activity, while at the same time finding justification for their hostility to the socialist system." Such propaganda also looks "to create within our country a political religious opposition to the Soviet system and to socialism, and to inflame nationalist sentiments on religious grounds." Ashirov then extensively defends the Soviet Union's record in its relations with Soviet Muslims. He notes that Soviet law forbids religious discrimination and that "after the victory of the proletarian revolution in Russia, the Communist Party and the Soviet government thought it possible - and even necessary - to preserve such institutions of Islam as mektebs, madrassas, Sharia courts, not to mention mosques. And this was in the period when the majority of Muslim organizations clearly took counterrevolutionary and anti-Soviet positions." Ashirov adds that "over the past few years, at the invitation of the Soviet Union, Muslim organizations annually visit the Soviet Union and many Muslim leaders from our country travel abroad. Thus, at the Tashkent conference of Muslims 'For the Unity of Muslims in the Struggle for Peace, against Imperialist Aggression' (1970), there were representatives from 24 foreign countries; the Samarkand conference 'Imam Bukhari and Modernity' was attended by Muslim religious leaders from 25 countries. After the conference began, the foreign Muslim leaders had the opportunity to tour the country and to exchange views with Muslims as well as people of other faiths and also non-believers." Finally, to emphasize his point that Soviet Muslims have benefitted from CPSU's policies, Ashirov states "More than half a century ago, the peoples of the Soviet East made their historical choice, connecting forever their fate with the fate of the workers of Russia, electing the path of building a communist society. Along this path, due to the help and cooperation of all of the country's peoples, they have achieved grandiose successes in all areas of life." 25 
The historical inaccuracies in Ashirov's book notwithstanding, Islam i Natsii demonstrates that in the mid-1970s, Soviet authorities felt the need to demonstrate to Soviet and non-Soviet Muslims the advantages of the Soviet socialist system. His work also demonstrates that during the Brezhnev period, Central Asia, Uzbekistan in particular, was used by the Soviet authorities as a model to demonstrate to Muslims and to the Third World peoples in general the successes of the Soviet system. As such, Moscow could not resort to severe crackdowns on Soviet Muslims or on nationalism in Central Asia as it would have severe repercussions for Soviet foreign policy, especially in the Middle East where Soviet prestige already sustained setbacks in the wake of Israeli victories in 1967 and 1973. Foreign policy concerns, then, combined with historical legacy and Brezhnev's trust in cadres policy to prevent the full-scale implementation of the principles of Developed Socialism in the Central Asian republics of the Soviet Union.

Foreign policy considerations also contributed greatly to the incomplete nature of the consolidation of the Soviet Empire during the Brezhnev period. Such considerations reinforce the existence of regional diversity in nationality policy as they partly explain why Moscow was more intolerant of nationalist manifestations in republics such as Ukraine and Georgia, yet tolerated nationalism and a resurgence of Islam in the Central Asian republics. Moreover, developments in Iran and Afghanistan in 1978-1979 only served to reinforce Moscow's inability to devise an effective strategy in Central Asia and even led to favorable references to the Islamic religion in the press and by Brezhnev himself.

As Soviet foreign policy became more involved in the Middle East and in other Third World countries in Africa, Central Asia and Islam became more important to Moscow, though never as important as the western republics or the Caucasian republics. In essence, Moscow's 
interests in the Third World, the Arab states in particular, led Soviet authorities to use Central Asia - especially Uzbekistan and its capital city Tashkent - as a showplace to the Muslim world and to the Third World in general as a showplace to reveal the supreme achievements of Soviet socialism in "backward" areas. These foreign policy interests also prompted Moscow to be more tolerant of resurgent Islamic activities as severe crackdowns on Islam would not play well among Moscow's Arab allies in the Middle East. Finally, problems in Afghanistan and Islam prompted Soviet officials to take public stances favorable to Islam. Such foreign policy concerns combined with historical legacy and Brezhnev's trust in cadres to prevent the more complete implementation of Developed Socialism in the Central Asian republics and contributed to the further development of the decolonization process there.

The motivations for Soviet involvement in the Third World in the 1960s and 1970s are varied according to the historiography. Three primary motivations for increased Soviet involvement in the Third World appear in the relevant literature: Cold War competition with the West, Leninist ideology and its strong anti-imperialist bent, and Soviet national security concerns in the regions close to its vast borders. Odd Arne Westad observes that upon assuming power in 1964, Brezhnev and his close colleagues had very little foreign policy experience. He writes, "Brezhnev told chief foreign policy advisor Aleksandrov-Agentov 'I never had anything to do with this damn foreign policy and know nothing about it." Westad argues that because of his lack of experience, Brezhnev's foreign policy had little to do with the Third World until 1968. In that year, Richard Nixon promised a quick American withdrawal from Vietnam and thus, Westad argues, "Third World activists within the Central Committee started using Indochina as an argument for increasing the attention paid to Asia, Africa, and Latin America. If the United States was willing to gamble with the future of South Vietnam - one of its key Third World 
allies - then the prospects for the survival of revolutions elsewhere seemed infinitely better than what they had been only a few years ago."26 Mark Webber observes that "Soviet expansion under Brezhnev certainly accorded with the inflated sense of status held in Moscow and the perception that socialism was on the march as a global force. This expansion brought with it, however, increasing costs measured in terms of economic overcommitment and political and military entanglements." Moreover, Webber argues, "that the Soviet leadership under Brezhnev increasingly thought in global terms and that Soviet foreign policy exhibited a generally expansionist predisposition toward obtaining a position of global advantage over the capitalist West. Whether or not this amounted to a carefully conceived grand design is, however, a quite different matter."27 Despite what Webber characterizes as an expansionist Soviet foreign policy under Brezhnev, other observers note that Brezhnev's primary foreign policy goal was détente ${ }^{28}$ with the United States and that "Brezhnev deeply loathed brinkmanship and the crisis-mongering that had characterized Khrushchev’s foreign policy since 1956. ${ }^{29}$

Regardless of the motivations, the Soviet Union became increasingly involved in the Third World during Brezhnev's tenure, most significantly in the Middle East. Vladislav Zubok notes that "The Politburo regarded the alliance with radical Arab regimes as the biggest geopolitical achievement of Soviet foreign policy since the end of World War II." It also proved to be the most costly in terms of money spent, the risk to the Soviet Union's prestige, and in the Brezhnev leadership's handling of the nationality issue within the Soviet Union. Zubok argues further that the Soviet Union continued to waste money in Egypt during the Brezhnev period "in a desperate attempt to maintain a Soviet presence in the Middle East. As a result, Soviet Middle East diplomacy became a hostage of Arab radicalism and demands. " ${ }^{30}$ It can be added that 
Soviet involvement in the Middle East and subsequent events in Afghanistan and Iran made Soviet nationality policy a hostage to authoritarian regimes that relied on Moscow's support.

In December 1979, the Soviet Union invaded Afghanistan to support the nascent communist regime there that was engaged in a bitter fight for its survival. Earlier that year, revolution in Iran toppled the shah and installed an Islamic state in that country. In the span of several months, then, the Soviet Union faced the growing threat of destabilization along its southern frontier. That events in both Afghanistan and Iran involved radical Islamic elements posed a threat to Soviet Central Asia, especially since large numbers of Tajiks, Uzbeks and Turkmen resided in Afghanistan and Iran. Events in both of these countries prompted Moscow to make rather surprising public statements regarding Islam that were likely intended to placate the peoples of Afghanistan and Iran, but may also have been indirectly intended for the millions of Soviet Muslims residing in Central Asia.

In regard to these developments, the KGB reported in October 1979 that "Evaluating the policy of the USSR in relation to the Iranian regime, the participants in the meeting came to the conclusion that insofar as strengthening the Islamic republic will lead to a weakening of the position of the regime in Afghanistan, exert a certain influence on the Muslim republics in the USSR and will 'be a break in the path of penetration of Communism in the region'..."31 The authorities in Moscow, then, were aware of the possible spillover of radical Islam from Iran and Afghanistan into the Soviet Union. Zubok notes that events in Afghanistan in particular were a sign that "Islamic fundamentalism had come on the scene." 32 Further evidence that the subsequent war in Afghanistan exacerbated religious issues in Central Asia is offered by Pikhoia who states, "Conscripts from the Central Asian republics - Tajiks, Uzbeks, Turkmen, and Kirgiz 
- refused to carry out orders [on the battlefields of Afghanistan], according to General B.V. Gromov, commander of the $40^{\text {th }}$ Army. They were replaced by conscripts from Russia." 33 At the $26^{\text {th }}$ CPSU Congress in 1981, Brezhnev declared, "Imperialism unleashed a real undeclared war against the Afghan revolution. This created a direct threat to the security of our southern border. This situation forced you to give the military assistance which had been requested by a friendly country." On events in Iran, Brezhnev noted "The revolution in Iran, which was a major event in the international arena in recent years, is of a special character. For all of its complexities and contradictions, it is inherently an anti-imperialist revolution, although its internal and external reaction tends to change the nature of it." He added that "The Iranian people are looking for a way to freedom and prosperity. We sincerely wish them success in this and are willing to develop good relations with Iran on the basis of equality and, of course, reciprocity." Then Brezhnev came to the substance of his analysis regarding the recent events in Afghanistan and Iran. He explained, "Recently, in some eastern countries Islamic slogans have been actively promoted. We Communists have respect for the religious beliefs of people professing Islam, like other religions. The important thing is for what purpose do these forces proclaiming certain slogans serve? A liberation struggle can unfold under the banner of Islam. This is evidenced by the experience of history, including that of recent history. But it can be said that Islamic slogans can contribute to counterrevolutionary riots. What matters, therefore, is the actual content of any movement." 34 Unfortunately, Brezhnev did not continue these thoughts on Islamic revolution. But it does appear that Brezhnev recognized the potential threat posed to the Soviet Union by the events in Iran and Afghanistan.

By the late 1970s, then, the Brezhnev leadership was confronted by the growing challenge posed by the resurgence of underground Islam and the beginnings of radical Islam in 
Central Asia. The Soviet government had never been able to eradicate Islam due largely to the religion's lack of a centralized clergical hierarchy, but it did try to control Islam through officially-sanctioned mosques and clergy administered by SADUM. Moreover, Islam is more than simply a religion, it also is deeply ingrained in the cultures of Muslim peoples. In 1979, Rasma Karklins interviewed several German emigres who had resided in Soviet Central Asia and she asked them about the continued adherence to Muslim religious traditions among the peoples of Central Asia and Kazakhstan. They stated that while many peoples in Central Asia did not overtly consider themselves Muslim, they still adhered to Islamic customs such as circumcision and the avoidance of eating pork. These interviews led Karklins to conclude that "Islam is not only a religion, but more: it is an ensemble of religious beliefs, social customs, and familial and national traditions. In short, it is a way of life." ${ }^{35}$ Even people who did not attend the official mosques sanctioned by SADUM or the underground mosques and schools still often adhered to Islamic traditions and customs. It was part of their identity.

Yet the Brezhnev leadership dealt with the resurgence of underground Islam and the retention of Islamic traditions by the Muslim peoples of the USSR in the same way that it approached the overall nationality issue. As N. Ashirov's book and the speeches of Soviet officials indicate, they believed that Islam could be contained in the same way that nationalism could be contained - through the tenets of Developed Socialism and their focus on consolidating more power at the center of the Soviet Empire at the expense of the union republics, the continued rhetoric on the rapprochement of nations, and through more internationalist atheistic propaganda. The Brezhnev leadership failed to appreciate that the resurgence of underground Islam - and the early development of radical trends within it - was not a purely nationalist movement. It was a movement that transcended the Muslim nations of the USSR and thus it was 
not the same as attempting to control or eradicate traditional nationalism such as that which existed in Ukraine or even in Uzbekistan.

\section{Assessing Developed Socialism - Mixed Results}

Marxism, and its Soviet variant Marxism-Leninism, are evolutionary theories that envision a future world free from class divisions and antagonisms in which people live and work freely without exploitation. Naturally, then, Soviet nationality policy at its heart was evolutionary, envisioning the gradual disappearance of national differences as class differences themselves withered away. Developed Socialism, as a theory and as a nationality policy, was also evolutionary. It developed in the first place as a careful way for the Brezhnev leadership to back away from Khrushchev's ambitious claims that the Soviet Union would begin the transition to communism by 1980 and that the Soviet nations would fuse together (sliianie). Developed Socialism sought to slow the evolutionary process further by proclaiming that the Soviet Union had substantially completed the building of socialism, but more was to be done before preparing for the transition to communism. The "material-technical" building of the economy had still to be undertaken before the country could transition into communism. Developed Socialism, then, was itself a transition - a transition from mature socialism to the transition into communism. In terms of nationality policy, proponents of Developed Socialism focused their efforts at promoting the rapprochement of nations, the mutual enrichment of national cultures through the process of rapprochement, the leadership of the more progressive Russian nation and its concomitant role as "elder brother" to the non-Russian peoples, particularly to the "less advanced" peoples of the Soviet East, the promotion of the Russian language as the natural means for inter-national communication within the Soviet Union, and finally the coming of the 
Soviet people (Sovetskii narod) which would eventually emerge as the result of the rapprochement of nations. Elements of Developed Socialism are imperialist in nature:

proponents naturally assumed that the Russian nation was the most advanced in the Soviet Union and displayed the best characteristics of civilization, the Russian language was viewed as the carrier of civilization to the "backward" peoples of the Soviet Union, non-Russians were encouraged and sometimes coerced into learning the Russian language while Russians were not expected to learn non-Russian languages, and finally the Sovetskii narod was expected to speak Russian and exhibit elements of Russian culture, albeit in an internationalist context. For the non-Russian peoples, then, the tenets of Developed Socialism promised more imperialism within the Soviet Union. Indeed, the focus on greater economic, social, linguistic, and cultural unity within the USSR called for by the proponents of Developed Socialism envisioned more imperialism for the Soviet Union. As indicated above, Developed Socialism's crowning achievement - the new USSR and Union Republic constitutions - enshrined into the fundamental laws of the Soviet Union a further consolidation of the Soviet Empire at the expense of republic sovereignty. Thus, to objective observers, Developed Socialism was an imperialist theory. Leonid Brezhnev and his colleagues were just as imperialist as their tsarist predecessors and just as imperialist the British colonial administrators in India, or French administrators in West Africa.

Still, to label Brezhnev-era nationality policy as imperialist is too simplistic. It must always be borne in mind that since its inception in 1917, the Soviet regime was constantly working on a major project - the building for the first time in human history of a communist future. Along the road ahead of them was the realization of this immense dream - a classless, stateless society that would enjoy the highest standard of living the world had ever seen. To the 
Soviet mind, nationality policies calling for the linguistic russification of non-Russian peoples, their rapprochement and eventual merger into a new Soviet nation (speaking Russian) were not imperialist, they were merely steps along an evolutionary path.

Recall that Lenin wrote in 1913 in "Critical Remarks on the National Question" that in the conditions of advanced capitalism, nations are undergoing a process of assimilation. Under socialism, Lenin argued, the assimilation of nations will only continue. The difference is that unlike in the conditions of advanced capitalism, nations under socialism are equal in stature, yet still unequal in terms of levels of development. All nations command equal respect, but some nations are more economically advanced than others due to the uneven development under capitalism. Lenin argued that under socialism, less advanced nations naturally will assimilate the more progressive qualities of the more advanced nations. But Lenin stressed that such assimilation must always be voluntary. Otherwise, it would be a form of great-nation chauvinism, which of course is imperialist. Moreover, Lenin wrote in his 1914 essay "Is a Compulsory Official Language Needed?" that he favors the opportunity for non-Russians to learn the Russian language and that it is only natural that non-Russians should want to learn Russian as the language forms one of the more progressive qualities of the more-advanced Russian nation. Thus, again, the less-advanced non-Russian peoples would naturally assimilate the Russian language as it is an avenue to progress. But again, Lenin stressed that linguistic russification must be voluntary or else it is imperialism.

Developed Socialism, then, is rooted in Leninist theory. When Brezhnev or a republic Party official spoke of improving the teaching of the Russian language, they always emphasized that it must be voluntary. When they described the Russian language as the vehicle for advanced culture and scientific knowledge for non-Russian peoples, they were in essence quoting Lenin. 
When they discussed the coming of the Soviet people, they were anticipating the future result of the evolutionary process of the rapprochement of nations. And finally, when they called the Russian nation the "elder brother" to the less-advanced non-Russian peoples, they did not mean to imply a colonial-type subordination. Rather, they intended for this to mean that the lessadvanced peoples naturally would borrow the best aspects of the more progressive Russian nation as Lenin had predicted. Thus, Brezhnev's imperialism was anti-imperialist. Brezhnev continued the project of building the anti-imperialist empire.

Theory aside, did Developed Socialism work as a nationality policy? This is a difficult question to answer as many of the tenets of Developed Socialism - particularly the rapprochement of nations and the forming of the Soviet people - were vague concepts to begin with and were really future goals of the Soviet system like the eventual transition to a communist society. Yet the more concrete aspects of Developed Socialism such as its focus on further consolidating the Soviet Empire at the expense of republic sovereignty and its call to improve the teaching of the Russian language in order to reinforce the Russian language as the lingua franca of the Soviet Union can be assessed with greater certainty. And the results here are mixed.

Brezhnev's primary goal of further consolidating the Soviet Empire had few successes and many more shortcomings. He succeeded in enforcing an overall ideological orthodoxy in the Soviet Union as is evidenced by the multitude of speeches and writings produced during his tenure that virtually all contain the same message. He also succeeded in enshrining in Soviet law a further consolidation of the Soviet Empire insofar as the new constitutions embodied these rather subtle, yet important changes. And perhaps most importantly of all, Brezhnev successfully maintained the integrity of the Soviet Empire and did so without sparking a large number of popular protests, a task that some of his colleagues in the neighboring Eastern 
European socialist states did not achieve and that his eventual successor, Mikhail Gorbachev, certainly failed in doing. Yet generally speaking, Brezhnev presided over a growing decolonization process that within just a few years of his passing would tear apart the Soviet Empire.

Brezhnev's efforts to consolidate further the Soviet Empire met with resistance from several existential factors, many of which contributed to the development of a decolonization process in the USSR. First, Brezhnev's own stated policy of trust in cadres allowed for the formation of an entrenched indigenous elite in the Union Republics, particularly in Central Asia. Essentially, Brezhnev's trust in cadres signaled a return to the policies of korenizatsiia and thus the return of what Terry Martin called the Affirmative Action Empire. Secondly, the continued existence of regional diversity in nationality policy contributed to the development of centripetal forces within the Soviet Empire. As has been discussed, the Brezhnev leadership exerted greater control over the western republics, a somewhat looser control over the Caucasian republics, and was largely ambivalent toward the Central Asian republics. Nationalism was allowed to develop in the Central Asian republics, so long as it did not directly pose a threat to Soviet authority or to the personal authority of republic leaders there, whereas it was barely tolerated in places like Ukraine. This therefore meant an uneven and incomplete consolidation of the empire. Third, the historical legacy inherited from tsarist times worked against a complete consolidation of the Soviet Empire. Moscow's traditional inability to co-opt Islam in Central Asia allowed for the growth of an Islamic identity there, the long history of resistance to both tsarist and Soviet rule in the Caucasus hampered Brezhnev's efforts to consolidate further those republics into the Soviet Empire, and the desire to control Ukraine economically partly explains why the Brezhnev leadership was less tolerant of nationalist manifestations there. Moreover, the recent Soviet 
acquisitions of the Baltic republics and Moldavia meant that these republics would always seem less completely "Sovietized" than their sister republics because they joined the empire late and nationalist resistance there remained strong, if still largely underground during the Brezhnev years. Fourth, population trends during the Brezhnev period favored the development of a decolonization process, especially in Central Asia and in the Caucasian republics. These trends also helped to contribute to nationalist sentiments in the Baltic republics. Finally, foreign policy pressures acted to reinforce the existence of regional diversity in terms of nationality policy. Because the western Soviet republics were on the front lines of the Cold War and bordered countries that had recently survived popular uprisings (Czechoslovakia and Poland), Moscow was keen to keep a tighter reign over these areas. Conversely, Soviet foreign policy strategies that backed anti-colonial movements worldwide and supported Arab states in the Middle East meant that the Brezhnev leadership had to be careful in its relations with the Central Asian Muslim republics. These republics were often used by Moscow as a model to Third World countries recently freed from colonial rule to demonstrate how Soviet socialism can transform "backward" feudal economies into modern miracles. Moreover, the Muslim areas of the Soviet Union were also used by Moscow as an example to show the Arab states that the Soviet Union treated its Muslims well. All of these trends, then, prevented the Brezhnev leadership from further consolidating the Soviet Empire and ultimately contributed to the development of a decolonization process that will eventually help to end the Soviet Empire.

The primary forces that acted to impede the complete fulfillment of Brezhnev's plans to consolidate further the Soviet Empire were his trust in cadres policy, demographic trends in the Soviet Union during the 1960s and 1970s, and Soviet foreign policy during the Brezhnev period. During the 18-year tenure of Brezhnev's leadership, the union republics had only one or two 
party first secretaries. In those cases where a change in the republic top leadership occurred, it was most often due to the death of the reigning first secretary. In only two cases - Georgia and Ukraine - did Brezhnev remove a party first secretary and both were at least in part due to the respective first secretaries being too tolerant of nationalism within their republics. In 1972, the longtime Georgian First Secretary Vasil Mzhavanadze was fired and replaced by Eduard Shevardnadze. Suny explains that Mzhvanadze was replaced due to "the widespread corruption in the administration of the republic, which in turn had caused consistently poor economic performances by Georgian industry and agriculture and the tolerance of nationalist tendencies within the party and intelligentsia." ${ }^{36}$ As noted above, Brezhnev removed Petro Shelest from his position as First Secretary of the Ukrainian Party because he too was too tolerant of Ukrainian nationalism to suit Moscow. Conversely, Heydar Aliev in Azerbaijan retained his post as First Secretary from 1969 to 1982 as "a successful pax sovietica was established in which dissident nationalist elements were ruthlessly suppressed, largely by a local leadership eager to retain the status quo through which relatively lavish lifestyles could be maintained through local networks of corruption." But Aliev kept his job as "He pleased his masters by expanding those sectors of the economy which were deemed to be of 'All-Union significance.",37

Brezhnev's trust in cadres was most evident in the Central Asian republics. Tajikistan's Rasulov and Uzbekistan's Rashidov both died in office in 1982 and 1983, respectively. The other three - Kirgizstan’s Usubaliev, Turkmenistan’s Gapurov and, most infamously, Kazakhstan's Kunaev - were forced into retirement by the new Gorbachev leadership after 1985 as part of Gorbachev's campaign to root out corruption. As was discussed above, Brezhnev's trust in cadres in the Central Asian republics - especially in Rashidov's Uzbekistan - fostered the development of nationalism in this part of the Soviet Union and thus contributed to the 
decolonization process there. As a result, the tenets of Developed Socialism highlighting the rapprochement of nations, linguistic russification, and the coming of the Soviet people were perhaps the weakest in Central Asia.

In addition to Brezhnev's trust in cadres policy, ongoing demographic trends worked to impede the process of consolidating the Soviet Empire and actually are the most concrete evidence of a decolonization movement in Central Asia and they help to explain in part why Moscow kept a tighter rein on the western republics than on the eastern republics. Between the 1959 and 1979 censuses, the percentage of Russians in the total population of each republic fell, except in the three Baltic republics, Byelorussia, and Ukraine. The absolute number of Russians living in each republic increased, but in the Caucasian and Central Asian republics, higher birthrates among the titular nationalities between 1959 and 1979 caused the Russians' share of the total population to decrease. This was most evident in Kirgizstan and in Turkmenistan, where the Russian proportion of the population between 1959 and 1979 fell from $30.2 \%$ to $25.9 \%$ in Kirgizstan and from $17.3 \%$ to $12.6 \%$ in Turkmenistan. ${ }^{38}$ 


\section{CONCLUSION}

\section{The Legacy of Brezhnev's Anti-Imperialist Empire}

Just a few weeks after assuming power in the fall of 1964, Brezhnev remarked in comments commemorating the anniversary of the October Revolution "We have successfully solved the nationality question - one of the most acute and difficult issues left to us from capitalism. Now all nations and nationalities in our country live in a united, brotherly family." To lengthy applause, Brezhnev later declared, "If we compare two political maps of the world, one from October 1917 and the other from today, we would see a great contrast showing the colossal change on our planet during this historic period. On the first map, the colors of the colonial powers cover the entirety of Asia and Africa. Today in the 1960s the countries of these continents fly the flags of sovereign states." ${ }^{11}$ However, the nationality problem had not been solved during Brezhnev's long tenure. By the time of his death in 1982, the rapprochement of nations had been left incomplete, the Soviet people as a new supranational nationality had not yet fully emerged, knowledge of the Russian language still languished at low levels in Central Asia and other parts of the Soviet Union, and nationalist sentiments were fomenting just below the surface all across the USSR. Indeed, due to Brezhnev's own trust in cadres policy and the historical legacy of viewing Central Asia as a distant periphery, the map of Brezhnev's own Soviet Union could have been colored with the flags of sovereign states in places such as Uzbekistan and Tajikistan. And of course Brezhnev could not have predicted that just three decades later, his own Soviet Empire would succumb to the forces of decolonization.

But this does not mean that Brezhnev's strategy for maintaining the Soviet Empire was a complete failure. To be sure, many of the facets of Developed Socialism were evolutionary in 
nature - the rapprochement of nations was intended to continue into the foreseeable future, the real appearance of the Soviet nation too was a goal for the future just like the goal of attaining communism. That Developed Socialism called for the pursuit of long-term goals should not count against Brezhnev in assessing his ability to maintain the Soviet Empire. Indeed, Brezhnev succeeded in keeping the empire together whereas his successors did not.

Though the full rapprochement of nations and the arrival of the Soviet nation did not occur during Brezhnev's lifetime, he did succeed in further consolidating the Soviet Empire both symbolically and in fact. Economically, he did further the process of making the USSR function as a single economic unit. This process did not begin under Brezhnev, but by ridding the country of Khrushchev's sovnarkhozy, Brezhnev re-centralized economic control in Moscow and reinvigorated the concept that Union Republics should specialize in certain economic sectors, Uzbekistan in cotton for example. Moreover, Brezhnev succeeded in enshrining into Soviet law the fundamentals of Developed Socialism through the ratification of the new USSR Constitution in 1977 and the new Union Republic constitutions in 1978. As demonstrated in Chapter Four, these documents represent a symbolic, but important, erosion of republic sovereignty in an effort to consolidate further the Soviet Empire.

Yet acting against the centralizing tendencies of Developed Socialism were Brezhnev’s own trust in cadres philosophy (which signaled a return to korenizatsiia policies at least as far as Central Asia was concerned), the historical legacy inherited from tsarist times that inhibited Moscow's ability to control Islam while encouraging keeping a tighter control on nationalist manifestations in the western republics, and foreign policy pressures that forced Moscow to tread lightly in Central Asia while still maintaining stronger constraints in the western republics. As a result of these pressures, decolonization proceeded in the Soviet Union during the Brezhnev 
years. Interestingly, however, multiple decolonization processes seemed to have been taking shape simultaneously in the Soviet Union during this period. As John Hargreaves and Gordon Martel have noted, decolonization often begins as the imperial power makes a conscious decision to "downsize" or restructure the imperial polity to elevate the colonized peoples to a more equal footing with the imperial power. In the case of the Soviet Union, the conscious effort to decolonize began immediately after the Bolsheviks won power. The early Bolsheviks actively encouraged the non-Russian peoples to join the Communist Party and to take a stake in their own cultural and economic development. Korenizatsiia policies led to the creation of what Terry Martin has called an Affirmative Action Empire in which indigenous elites were elevated to positions of authority. These actions, then, reflected a conscious decision on the part of the imperial power to restructure the old Russian Empire into what would become the AntiImperialist Empire. Brezhnev rekindled korenizatsiia through his trust in cadres policy which allowed indigenous elites in places like Uzbekistan, Kazakhstan, Azerbaijan, Georgia, and even in Lithuania and Latvia to entrench themselves firmly in power. Brezhnev tolerated this situation unless local corruption or the toleration of local manifestations of nationalism got out of hand and threatened Soviet interests. Thus, especially in Central Asia, nationalist sentiments were allowed to develop and even flourish - recall James Critchlow's observations that Uzbek intellectuals worked to expunge Russian terms from the Uzbek language, efforts that were encouraged by Sharaf Rashidov and tolerated by Moscow. Therefore, Brezhnev's own policies contradicted the principles of Developed Socialism and contributed to the top-down decolonization process begun by the Bolsheviks in the 1920s.

At the same time, Brezhnev's policies in other parts of the Soviet Union - Ukraine and the Caucasus in particular - clamped down on top-down decolonization and thus unintentionally 
promoted decolonization from below. Whereas the decolonization in Central Asia was "planned" in that policies dating to the 1920s and reinvigorated by Brezhnev in the 1960s and 1970s enabled indigenous leaders to do almost as they wished so long as they placated Moscow in rhetoric and economic performance, the decolonization in Ukraine and in the Caucasus was decidedly unplanned. Shelest in Ukraine was too tolerant of Ukrainian nationalism, which could pose a threat to Soviet security so Brezhnev removed him. The new boss in Ukraine, Volodymyr Shcherbitskii, was Moscow's man in Kiev and thus far more pro-Russian (and therefore a more willing supporter of Developed Socialism, particularly the tenets calling for the internationalization of the Soviet working class which meant more russification). Likewise, in Georgia, Brezhnev removed Mzhvanadze for his corrupt actions that led to the entrenchment of a decidedly Georgian power base, which potentially could threaten Brezhnev’s plans to consolidate further the Soviet Empire. Moreover, the draft constitutions of Georgia, Armenia, and Azerbaijan proposed to do away with the provisions declaring Georgian, Armenian and Azerbaijani the state languages of those republics. Street protests in Georgia and Armenia quickly ended these attempts to erode Georgian, Armenian and Azerbaijani sovereignty and thus stymied Brezhnev's attempts to bring the three Caucasian republics into closer integration with the empire. Underground nationalist movements would continue to develop in these parts of the Soviet Union which would quickly rise to the surface after Gorbachev assumed power.

Brezhnev also successfully maintained the Soviet Union's external informal empire in Eastern Europe, though not without difficulty. The Prague Spring in Czechoslovakia presented the greatest challenge to maintaining the unity of the informal empire and necessitated the invasion of that country by Warsaw Pact troops led by the Soviet Union. However, the crushing of the Prague Spring also further strained relations between Moscow and Romania as Ceausescu 
refused to allow Romanian troops to take part in the invasion of Czechoslovakia. It was also at this time as discussed in Chapter Five that intellectuals in Ceausescu's Romania began criticizing the Soviet annexation of Moldavia in 1940. Brezhnev also threatened Poland with invasion in 1980-81 in response to the growing Solidarity movement, but this was averted when Poland's leadership imposed martial law on the country. Thus, just as in the internal Soviet Empire, cracks were appearing in the Soviet Union's external informal empire in Eastern Europe, but Brezhnev was able to maintain the informal empire whereas his successors could not.

Brezhnev's nationality policy, then, was fraught with contradictions as is the entire course of Soviet history. But he still succeeded in keeping the empire together. Ultimately, it was Brezhnev's strict adherence to ideological orthodoxy and his regime's unwavering insistence on not deviating from the Party line that contributed the most to maintaining the antiimperialist empire. Party officials and academicians from all fields produced copious amounts of speeches and writings during the eighteen years of Brezhnev's reign and reading all of them would take a lifetime. When reviewing these materials, the researcher is immediately struck by the level of uniformity in these speeches, essays, and books. The conservatism of the Brezhnev period, though, was the Brezhnev leadership's most effective tool in maintaining the Soviet Empire. Gorbachev forgot this lesson, which played a large role in the unravelling of the Soviet Empire in 1991.

\section{Gorbachev and the Unravelling of the Soviet Empire}

It is beyond the scope of the present study to provide an in-depth analysis of the collapse of the Soviet Union. A myriad of books and essays have been published in the last twenty years that explore how and why the Soviet Union unexpectedly broke apart in 1991. However, in light 
of Brezhnev's strategies for maintaining the Soviet Empire, some observations on Gorbachev can be made.

First, Gorbachev, like his predecessors, did not fully appreciate the scale of the nationality problem. Indeed, Gorbachev in his Memoirs appears rather naïve on the nationality issue. He writes, "When I discussed my origins and roots in Stavropol I mentioned the special character of this place, which became part of my life: people of different nationalities living side by side." To be sure, Gorbachev states, "As I came into contact with the culture, traditions and peculiarities of life and human relationships among the dozens of peoples dwelling in the Caucasus, I recognized the delicacy of this subject. Spontaneous flareups of nationalist passions were a real danger..."2 However, although he recognized the potential dangers inherent in the nationalities issue, Gorbachev later notes that "My experience nourished the conviction that there was only one possible way to handle this problem, through cooperation! Repression was useless, since the problems remained unsolved."3 Philosophically, Gorbachev is correct that cooperation is the best way to handle the nationality problem, but given the circumstances of Soviet history and in light of the events that unfolded during his time in office, Gorbachev's insistence on cooperation appears naïve. As will be noted below, Gorbachev himself realized that force was necessary to maintain the Soviet Empire.

Secondly, a key reason the Soviet Empire collapsed is that Gorbachev abandoned first the conservatism of the Brezhnev period and later abandoned Marxist-Leninist ideological orthodoxy. The conditions created by glasnost' and perestroika opened the door for nationalist sentiments - which had largely been kept underground and in check during the Brezhnev period - to come to the forefront not only in the non-Russian republics but in Russia itself. Russian nationalism - which had already begun to emerge under Brezhnev and had been officially 
sanctioned by the Brezhnev regime to a certain extent - blamed the Soviet system generally and the existence of minorities within the Russian Republic for many of their nation's ills. Moreover, many Russian nationalists grew increasingly concerned for their co-nationals living in other Soviet republics - do "they deserve to be seen as colonialist pieds-noirs?" In addition to Russia, glasnost' and perestroika created the conditions for other nationalisms to come out into the open. Historical grudges against Russians and fellow non-Russians often developed into clashes such as in the case of Armenians and Azerbaijanis fighting over Nagorno-Karabakh. Such nationalist sentiments did not just suddenly form overnight as soon as Gorbachev assumed office. They certainly existed during the Brezhnev period and much earlier. But they quickly emerged into the open because Gorbachev abandoned the conservative orthodoxy that pervaded the Brezhnev period.

Third, Gorbachev abandoned Brezhnev's trust in cadres policy in an effort to remove corrupt Party officials and to ensure that his supporters held important Party posts. In December 1986, Gorbachev removed Dinmukhamen Kunaev from his post as First Secretary in Kazakhstan - a position he had held since 1964 - and replaced him with an ethnic Russian. Mass protests erupted across the Kazakh Republic with nine demonstrators killed and 500 arrested. Despite this violence, Keep observes that "the proportion of non-Russians in leading Party bodies tended to decline during the early years of perestroika."5 Gorbachev's abandonment of Brezhnev's trust in cadres meant also that he was abandoning korenizatsiia, which, in the case of the Kazakhs, sparked nationalist unrest. The Kunaev incident also reinforces the fact that Gorbachev was naïve in terms of nationality affairs. He writes, "I do not think that Kazakhstan was suffering from serious nationality conflicts when trouble surfaced there in December 1986." ${ }^{\circ}$ Gorbachev's mistake in Kazakhstan reveals the extent to which Brezhnev's trust in cadres policy had gone in 
fostering a decolonization process in the Central Asian republics. Although Kunaev was highly corrupt and he (like Rashidov in Uzbekistan) ran Kazakhstan as an autocrat, he had been beneficial for the Kazakhs. Under Kunaev, reforms "in higher education allowed a higher percentage of the indigenous nationalities to attend universities and to take advantage of better job opportunities. While Kunaev remained in power, the Kazakhs were over-represented in many administrative and party positions, as well as in numerous official posts."7 Thus while Kunaev should have been removed due to his corruption, the Kazakhs resented the fact that his replacement was a Russian. Gorbachev writes that he spoke with Kunaev and informed him that members of the Kazakh Party were making troubling reports about Kunaev, which prompted Kunaev to resign rather than be fired. Gorbachev further claims that it was Kunaev who suggested Gennadii Kolbin - the ethnic Russian - as his replacement as Kunaev wanted to prevent his rival Nazarbaev from being named his successor. So Gorbachev went along with Kunaev's suggestion. In his own defense, Gorbachev writes, “In spite of Kunayev’s advice and the consent of the republic leadership, we should have realized that it would be difficult for Kazakhs to accept a Russian in this position. We were at the beginning of perestroika, but to some degree we were still following the old ways." ${ }^{8}$ I would argue instead that Gorbachev was not following the old ways - Brezhnev likely would have found a Kazakh to replace Kunaev. After all, he found Shcherbitskii (a Ukrainian) to replace Shelest and he found Shevardnadze (a Georgian) to replace Mzhvanadze. Had Gorbachev adhered to Brezhnev's revival of korenizatsiia the 1986 Kazakh riots may have been avoided.

Finally, Gorbachev proved to be the ultimate anti-imperialist imperialist. He was willing to let go of the Soviet Union's informal empire in Eastern Europe and he pushed for the formation of the new Soviet parliament, the Congress of Peoples' Deputies, which gave a greater 
voice to the republics in deciding all-Union matters. But Gorbachev remained committed to the Soviet Empire, even resorting to the use of armed troops in Georgia and Lithuania to keep the empire together - something Brezhnev never had to do. When the three Baltic republics proclaimed their sovereignty in 1990, Gorbachev writes that "We could not deny the right of nations to self-determination, even to the point of secession. It was provided for in our Constitution. Nevertheless, we had to do everything possible to show the people the catastrophic consequences of this step." Moreover, when preparing the draft of a new Union Treaty, according to Gorbachev, "The role of Russia as the consolidating component in the Union was indicated in the draft, and it contained proposals to resolve the questions pertaining to the legal status of the RSFSR." Thus, Gorbachev continued to adhere to certain of the principles of Brezhnev's Developed Socialism - the nations should be allowed to develop, but the Russian nation is the tie that binds the Soviet Empire together. That Gorbachev was willing to resort to the use of force in Lithuania and Georgia to maintain the Soviet Empire is perhaps the greatest irony in the entire course of Soviet history especially in light of his democratic leanings in all other aspects of his tenure and in light of Brezhnev's strategies for maintaining the empire.

Thus the Anti-Imperialist Empire ended in spite of Gorbachev's efforts to maintain it by force. It ended largely as the result of the decolonization process unleashed by the Bolsheviks in the 1920s. The rapprochement of nations never materialized; the Soviet nation proved stillborn. Ironically, the Soviet Empire came to an end because of the success of Leninist policies that encouraged the development of nations and states where they had never before existed. In this respect, then, the Soviet Empire fell victim to its own success. 
Introduction

${ }^{1}$ John Keep. Last of the Empires: A History of the Soviet Union 1945-1991. Oxford: Oxford University Press, 1995.

${ }^{2}$ Dmitri Volkogonov. Autopsy for an Empire: The Seven Leaders Who Built the Soviet Regime. Tr. Harold Shukman. New York: The Free Press, 1998.

${ }^{3}$ One of my primary intentions for this entire study is to remain as neutral and objective as possible. As will be discussed later, much of Western Soviet historiography suffers from lack of objectivity as some historians seem to use their works to reveal the "evilness" of the Soviet Union and why it was doomed to the dustbin of history. These works are often still very useful, but 20 years after the end of the Cold War, it is now time to re-examine Soviet history through a more objective lens.

\section{Chapter One}

${ }^{1}$ For other discussions of empire and its definition, see D.K. Fieldhouse. Economics and Empire, 1830-1914. Ithaca: Cornell University Press, 1973; Herfried Munkler. Empires: The Logic of World Domination from Ancient Rome to the United States. Malden, Mass.: Polity, 2007; John Darwin. "Imperialism and the Victorians: The Dynamics of Territorial Expansion" The English Historical Review, Vol. 112, No. 447 (June 1997).

${ }^{2}$ Michael W. Doyle. Empires. Ithaca: Cornell University Press, 1986. 45.

${ }^{3}$ Doyle, 45.

${ }^{4}$ Doyle, 128-29.

${ }^{5}$ Doyle, 135.

${ }^{6}$ Doyle.

${ }^{7}$ Doyle, 96.

${ }^{8}$ Doyle.

${ }^{9}$ John D. Hargreaves. Decolonization in Africa. New York: Longman, 1988. xv.

${ }^{10}$ Gordon Martel. "Decolonisation after Suez: Retreat or Rationalisation?" Australian Journal of Politics and History, Vol. 26; No. 3 (2000). 403.

${ }^{11}$ Nicholas J. White. "The Business and the Politics of Decolonization: The British Experience in the Twentieth Century." Economic History Review, Vol. LIII; No. 3 (2000). 544-545.

${ }^{12}$ Robin W. Winks. "On Decolonization and Informal Empire.” The American Historical Review, Vol. 81; No. 3 (June 1976). 540-542.

${ }^{13}$ William Roger Louis \& Ronald Robinson. “The Imperialism of Decolonization” in The Decolonization Reader. Ed. James D. LeSueur. New York: Rutledge, 2003. 49-50.

${ }^{14}$ Joseph Morgan Hodge. Triumph of the Expert: Agrarian Doctrines of Development and the Legacies of British Colonialism. Athens: Ohio University Press, 2007. 207-208.

${ }^{15}$ Hodge, Triumph of the Expert, 208.

${ }^{16}$ See Nicholas J. White. "The Frustrations of Development: British Business and the Late Colonial State in Malaya, 1945-57." Journal of Southeast Asian Studies Vol. 28, No. 1 (March 1997).

${ }^{17}$ A.J. Stockwell. "Imperialism and Nationalism in South-East Asia" in The Oxford History of the British Empire, Vol. IV: The Twentieth Century. Judith M. Brown \& William Roger Louis, Eds. Oxford: Oxford University Press, 1999. 483-484.

${ }^{18}$ As will be discussed in Chapter Four, Brezhnev's policies in the 1970s closely resembled Britain's second colonial occupation.

${ }^{19}$ Tony Chafer. The End of Empire in French West Africa: France's Successful Decolonization? Oxford: Berg, 2002. 31.

${ }^{20}$ Chafer, 32-33.

${ }^{21}$ Chafer, 33.

${ }^{22}$ Chafer, 56.

${ }^{23}$ Chafer, 63.

${ }^{24}$ Hargreaves, 81.

${ }^{25}$ Chafer, 76. 
${ }^{26}$ Martin Shipway. Decolonization and its Impact: A Comparative Approach to the End of Colonial Empires.

Malden, Mass.: Blackwell Publishing, 2008. 116.

${ }^{27}$ Shipway, 122-23.

${ }^{28}$ Clive Whitehead. "The Medium of Instruction in British Colonial Education: A Case of Cultural Imperialism or Enlightened Paternalism?" History of Education, Vol. 24, No. 1 (1995). 3-4.

${ }^{29}$ Whitehead, "The Medium of Instruction in British Colonial Education", 7.

${ }^{30}$ Whitehead, "The Medium of Instruction in British Colonial Education", 12.

${ }^{31}$ Shipway, Decolonization and its Impact, 32.

32 Olakunle A. Lawal. "From Colonial Reforms to Decolonization: Britain and the Transfer of Power in Nigeria, 1947-1960." Journal of the Historical Society of Nigeria Vol. 19 (2010). 41.

${ }^{33}$ James Onley. "The Raj Reconsidered: British India's Informal Empire and Spheres of Influence in Asia and Africa" Asian Affairs, Vol. XL, No. 1 (March 2009). 44.

${ }^{34}$ Andreas Kappeler. The Russian Empire: A Multiethnic History. Tr. Alfred Clayton. Harlow, England: Longman, 2001. 26-27.

${ }^{35}$ Geoffrey Hosking. Russia: People and Empire, 1552-1917. Cambridge: Harvard University Press, 1997. 5.

${ }^{36}$ Hosking, 14.

${ }^{37}$ Kapeler, 78-80.

${ }^{38}$ Kappeler, 193.

${ }^{39}$ Kappeler, 193.

${ }^{40}$ Kappeler, 29.

${ }^{41}$ Mehmet Tepeyurt. Bashkirs Between Two Worlds, 1552-1824. Ph.D. Dissertation. Morgantown: West Virginia University, 2011. 29-34.

${ }^{42}$ Kappeler, 29.

${ }_{43}^{43}$ Kappeler, 168.

${ }^{44}$ Kappeler, 175.

${ }^{45}$ Kappeler, 253.

${ }^{46}$ Terry Martin. The Affirmative Action Empire: Nations and Nationalism in the Soviet Union, 1923-1939. Ithaca: Cornell University Press, 2001. 19.

${ }^{47}$ Richard Pipes. The Formation of the Soviet Union: Communism and Nationalism 1917-1923 Revised Edition. Cambridge: Harvard University Press, 1997. 10-11.

${ }^{48}$ Pipes, 22.

${ }^{49}$ Pipes, 23. Pipes notes, however, that Luxembourg did support the movements of small nationalities, in particular those in the Balkans who were fighting for their independence.

${ }^{50}$ Helene Carrere d'Encausse. The Great Challenge: Nationalities and the Bolshevik State 1917-1930. Tr. Nancy Festinger. New York: Holmes \& Meier, 1992. 13.

${ }^{51}$ d'Encausse, The Great Challenge, 14.

52 d'Encausse, The Great Challenge, 15-16.

${ }^{53}$ d'Encausse, The Great Challenge ,17.

${ }^{54}$ Pipes, 42.

${ }^{55}$ Pipes, 43-45.

${ }^{56}$ d'Encausse, The Great Challenge , 67-68.

${ }^{57}$ Gregory Gleason. Federalism and Nationalism: The Struggle for Republican Rights in the USSR. Boulder: Westview Press, 1990. 32.

${ }^{58}$ Lenin quoted in Gleason, 35.

${ }^{59}$ Geoffrey Hosking. Rulers and Victims: The Russians in the Soviet Union. Cambridge: Belknap Press, 2006. $72-$ 73.

${ }^{60}$ Francine Hirsch. Empire of Nations: Ethnographic Knowledge and the Making of the Soviet Union. Ithaca: Cornell University Press, 2005. 5.

${ }^{61}$ Hirsch, 7-8.

${ }^{62}$ Hirsch, 8.

${ }^{63}$ Hirsch, 14.

${ }^{64}$ Martin, 76.

${ }^{65}$ Martin, 10. 
${ }^{66}$ Martin, 12.

${ }^{67}$ Martin, 4.

${ }^{68}$ Kappeler, 273-279.

${ }^{69}$ Martin, 23.

${ }^{70}$ Martin, 24.

${ }^{71}$ Martin, 19-20.

${ }^{72}$ Hirsch, 86-97.

${ }^{73}$ Robert Service. Stalin: A Biography. Cambridge: Belknap Press, 2005. 338.

${ }^{74}$ Mark B. Tauger. "Stalin, Soviet Agriculture, and Collectivisation" in Food and Conflict in Europe in the Age of the Two World Wars. Frank Trentmann \& Fleming Just, Eds. New York: Palgrave MacMillan, 2006. 116-119.

${ }^{75}$ Martin, 238-240.

${ }^{76}$ Martin, 270.

${ }_{77}^{77}$ Martin, 271.

${ }^{78}$ The following discussion of Stalin's editing of the Short Course is from David Brandenberger \& Mikhail V. Zelenov. "Stalin's Answer to the National Question: A Case Study on the Editing of the 1938 Short Course". Slavic Review, Vol.73, No. 4 (Winter 2014). 859-880.

${ }^{79}$ All of the following information regarding Tadzhikistan is from Theresa Rakowska-Harmstone. Russia and Nationalism in Central Asia: The Case of Tadzhikistan. Baltimore: The Johns Hopkins Press, 1970.

${ }^{80}$ Rakowska-Harmstone, 39.

${ }^{81}$ Rakowska-Harmstone, 41.

${ }^{82}$ Rakowska-Harmstone, 75.

${ }^{83}$ Rakowska-Harmstone, 75.

${ }^{84}$ The annexations of these states and regions will be discussed in greater detail in Chapter 5.

${ }^{85}$ Richard Overy. Russia's War: A History of the Soviet War Effort, 1941-1945. New York: Penguin Books, 1997. 128.

${ }^{86}$ Orest Subtelny. Ukraine: A History. Second Edition. Toronto: University of Toronto Press, 1994. 441.

${ }^{87}$ Subtelny, Ukraine, 443-444.

${ }^{88}$ On the similarities between Ukrainian integral nationalism and Nazism, see Karel Berkhoff \& Marko Carynnyk. "The Organization of Ukrainian Nationalists and Its Attitude Toward Germans and Jews: Iaroslav Stets'ko's 1941 Zhyttiepys." Harvard Ukrainian Studies Vol.23, No. 3/4 (December 1999). 149-184. See also John A. Armstrong. "Collaborationism in World War II: The Integral Nationalist Variant in Eastern Europe." The Journal of Modern History Vol. 40, No. 3 (Sept. 1968). 396-410. Although there were similarities in the integral nationalism of the OUN and the Nazis, these authors are careful to point out that the Ukrainian nationalists in the OUN were not necessarily Fascists.

${ }^{89}$ Subtelny, Ukraine, 471-474.

${ }^{90}$ William Taubman. Khrushchev: The Man and His Era. New York: W.W. Norton, 2003. 193-197.

${ }^{91}$ This will be discussed in Chapter 5 .

${ }^{92}$ Edy Kaufman. The Superpowers and their Spheres of Influence. London: Croom Helm, 1976. 172-173.

${ }^{93}$ Zbigniew K. Brzezinski. The Soviet Bloc: Unity and Conflict. Cambridge: Harvard University Press, 1967. 4-5.

${ }^{94}$ Brzezinski, The Soviet Bloc, 71.

${ }^{95}$ Brzezinski, The Soviet Bloc, 115.

${ }^{96}$ John Lewis Gaddis. We Now Know: Rethinking Cold War History. Oxford: Oxford University Press, 1997. 2833.

${ }^{97}$ On this, see Vladimir Tismaneanu. Reinventing Politics: Eastern Europe from Stalin to Havel. New York: The Free Press, 1992. See also Mark Pittaway. Eastern Europe, 1939-2000. New York: Oxford University Press, 2004.

${ }_{98}$ James Onley. "The Raj Reconsidered: British India's Informal Empire and Spheres of Influence in Asia and Africa." Asian Affairs, Vol. XL, No. 1 (March 2009). 44.

${ }^{99}$ Ian Copland. The Princes of India in the Endgame of Empire, 1917-1947. Cambridge: Cambridge University Press, 1997. 15-16.

${ }^{100}$ Barbara N. Ramusack. The Indian Princes and their States. Cambridge: Cambridge University Press, 2004. 49.

${ }^{101}$ Brzezinski, The Soviet Bloc, 118. 


\section{Chapter Two}

${ }^{1}$ Ronald Grigor Suny. The Soviet Experiment: Russia, the USSR, and the Successor States. New York: Oxford University Press, 1998. 390.

${ }^{2}$ Suny, 411.

${ }^{3}$ Ben Fowkes. The Disintegration of the Soviet Union: A Study in the Rise and Triumph of Nationalism. New York: St. Martin's Press, 1997. 79.

${ }^{4}$ George Breslauer. Khrushchev and Brezhnev as Leaders: Building Authority in Soviet Politics. London: George Allen \& Unwin, 1982. 74.

${ }^{5}$ Martin McCauley. The Khrushchev Era 1953-1964. Harlow, England: Pearson Education, 1995. 30.

${ }^{6}$ Helene Carrerre d'Encausse. "When the Prison of Peoples was Opened" in The Soviet Nationality Reader: The Disintegration in Context. Ed. Rachel Denber. Boulder: Westview Press, 1992. 96.

${ }^{7}$ d'Encausse, "When the Prison of Peoples was Opened", 97.

${ }^{8}$ Suny, The Soviet Experiment, 410.

9 John L. H. Keep. Last of the Empires: A History of the Soviet Union, 1945-1991. Oxford: Oxford University Press, 1995. 142-43.

${ }^{10}$ Keep, 145.

${ }^{11}$ Keep, 144.

${ }_{13}^{12}$ Fowkes, 81.

${ }^{13}$ Suny, The Soviet Experiment, 411.

${ }^{14}$ Bohdan Nahaylo \& Victor Swoboda. Soviet Disunion: A History of the Nationalities Problem in the USSR. New York: The Free Press, 1990. 179.

${ }^{15}$ Victor Zaslavsky. "The Soviet Union" in After Empire: Multiethnic Societies and Nation-Building: The Soviet Union and the Russian, Ottoman, and Habsburg Empires Eds. Karen Barkey \& Mark von Hagen. Boulder: Westview Press, 1997. 85.

${ }^{16}$ Zaslavsky, "The Soviet Union", 87.

${ }^{17}$ Ben Fowkes. "The National Question in the Soviet Union under Leonid Brezhnev: Policy and Response" in Brezhnev Reconsidered Edwin Bacon \& Mark Sandle, Eds. New York: Palgrave MacMillan, 2002. 68.

${ }^{18}$ Valerie Bunce \& John M. Echols III. "Soviet Politics in the Brezhnev Era: 'Pluralism' or 'Corporatism'?" in Soviet Politics in the Brezhnev Era. Donald R. Kelley, Ed. New York: Praeger Publishers, 1980. 3-5.

${ }^{19}$ Fowkes, "The National Question", 68.

${ }^{20}$ Fowkes, "The National Question", 72.

${ }^{21}$ Ben Fowkes. The Disintegration of the Soviet Union: A Study in the Rise and Triumph of Nationalism. New York: St. Martin's Press, 1997. 81.

${ }^{22}$ Fowkes, The Disintegration of the Soviet Union, 90.

${ }^{23}$ Fowkes, "The National Question", 78.

${ }^{24}$ John Keep. Last of the Empires: A History of the Soviet Union 1945-1991. Oxford: Oxford University Press, 1995. 158.

${ }^{25}$ Keep, Last of the Empires, 308.

${ }^{26}$ Martha Brill Olcott. "Yuri Andropov and the 'National Question"”. Soviet Studies, Vol. 37 No. 1 (Jan. 1985), 105.

${ }^{27}$ Dina Zisserman-Brodsky. Constructing Ethnopolitics in the Soviet Union: Samizdat, Deprivation, and the Rise of Ethnic Nationalism. New York: Palgrave Macmillan, 2003. 24.

${ }^{28}$ Helene Carrere d'Encausse. Decline of an Empire: The Soviet Socialist Republics in Revolt. New York: Newsweek Books, 1979. 121-122.

${ }^{29}$ William Tompson. The Soviet Union Under Brezhnev. London: Pearson Education, 2003. 6.

${ }^{30}$ William Tompson. The Soviet Union Under Brezhnev. 22.

${ }^{31}$ Leonid Il'Ich Brezhnev. "Rech' na Konferentsii Evropeiskikh Kommunisticheskikh i Rabochikh Partii, 24 Aprelia 1967 goda" in L.I. Brezhnev: Izbrannye Proizvedeniia v Trekh Tomakh, Tom I: 1964-1970. Moscow: Izdatel'stvo Politicheskoi Literatury, 1981. 240.

32 Brezhnev, "Rech' na Konferentsii...", 240.

${ }_{33}$ Benedict Anderson. Imagined Communities: Reflections on the Origin and Spread of Nationalism. London: Verso, 1991. 6-7. 
${ }^{34}$ J.V. Stalin. "Marxism and the National Question" in J. V. Stalin: Works, Volume II, 1907-1913. Moscow:

Foreign Languages Publishing House, 1953. 307.

${ }^{35}$ Stalin, "Marxism and the National Question", 303.

${ }^{36}$ Stalin, "Marxism and the National Question", 305.

${ }^{37}$ Stalin, "Marxism and the National Question", 376.

${ }^{38}$ V.I. Lenin. "Critical Remarks on the National Question" in V.I. Lenin Collected Works, Vol. 20, December 1913August 1914. Moscow: Progress Publishers, 1977.

${ }^{39}$ Lenin, "Critical Remarks on the National Question", 31-33.

${ }^{40}$ Lenin, "Critical Remarks on the National Question", 35.

${ }^{41}$ V.I. Lenin. "Is a Compulsory Official Language Needed?" in V.I. Lenin Collected Works, Vol. 20, December 1913-August 1914. Moscow: Progress Publishers, 1977. 72.

${ }^{42}$ J.V. Stalin. "The National Question and Leninism" in J.V. Stalin: Works, Vol. 11, 1928-March 1929. Moscow: Foreign Languages Publishing House, 1954. 355-360.

${ }^{43}$ Stalin, "The National Question and Leninism", 362.

${ }^{44}$ V.I. Kozlov. "Nekotorye Problemy Teorii Natsii" in Voprosy Istorii (January 1967), 89.

${ }^{45}$ Kozlov, "Nekotorye Problemy Teorii Natsii", 93-94.

${ }^{46}$ Kozlov, "Nekotorye Problemy Teorii Natsii", 96-97.

${ }^{47}$ Kozlov, "Nekotorye Problemy Teorii Natsii", 98.

${ }^{48}$ M.S. Dzhunusov. "Natsiia kak sotsial'no-etnicheskaia obshchnost' liudei" in Voprosy Istorii (April 1966), 20.

${ }^{49}$ Dzhunusov, "Natsiia kak sotsial'no-etnicheskaia obshchnost' liudei", 21.

${ }^{50}$ Dzhunusov, "Natsiia kak sotsial'no-etnicheskaia obshchnost' liudei”, 24.

${ }^{51}$ Dzhunusov, "Natsiia kak sotsial'no-etnicheskaia obshchnost' liudei", 24.

${ }^{52}$ Dzhunusov, "Natsiia kak sotsial'no-etnicheskaia obshchnost' liudei", 27.

${ }^{53}$ N.A. Tavakalian. "Nekotorye Voprosy Poniatiia "Natsiia" in Voprosy Istorii (February 1967), 120.

${ }^{54}$ N.A. Tavakalian. "Nekotorye Voprosy Poniatiia 'Natsiia", 120.

${ }^{55}$ V.I. Lenin. Imperialism: The Highest Stage of Capitalism, A Popular Outline. New York: International Publishers, 1974. 21-22.

${ }^{56}$ Lenin, Imperialism, 62.

${ }^{57}$ Lenin, Imperialism, 77-78.

${ }^{58}$ Lenin, Imperialism, 89.

\section{Chapter Three}

1 "Brezhnev's Speech on Anniversary of the Revolution" in Current Digest of the Soviet Press, Vol. XVI, No. 43 (November 18, 1964). 4.

2 "Brezhnev's Speech on Anniversary of the Revolution" in Current Digest of the Soviet Press, Vol. XVI, No. 43 (November 18, 1964). 4.

3 "Podgorny on Nationalities, Economic Reorganization" in Current Digest of the Soviet Press Vol. XVII, No. 21 (June 1965). 4.

4 "Friendship of Peoples vs. Nationalism and Localism" in Current Digest of the Soviet Press Vol. XVII, No. 46 (November 1965). 8-10.

5 "Soviet National Linguistic Policy Seen as a Model" in Current Digest of the Soviet Press Vol. XVII, No. 47 (December 1965). 14-19.

${ }^{6}$ T.U. Usubaliev. "Otchet Tsentral'nogo Komiteta Kompartii Kirgizii XIV S"ezdu Kommunisticheskoi Partii Kirgizii” XIV S”ezd Kommunisticheskoi Partii Kirgizii, 3-4 Marta 1966g. Stenograficheskii otchet. Frunze: Kirgizstan, 1980. 17-18.

${ }^{7}$ Usubaliev "Otchet" XIV S"ezd Kommunisticheskoi Partii Kirgizii 1966. 41.

${ }^{8}$ Speech by A.V. Samosudov to the $14^{\text {th }}$ Kirgiz Party Congress. XIV S"ezd Kommunisticheskoi Partii Kirgizii 1966. 85.

${ }^{9}$ Speech by T. Kulatov to the $14^{\text {th }}$ Kirgiz Party Congress. XIV S"ezd Kommunisticheskoi Partii Kirgizii 1966. 96. ${ }^{10}$ Speech by S. Tabyshchaliev to the $14^{\text {th }}$ Kirgiz Party Congress. XIV S" $e z d$ Kommunisticheskoi Partii Kirgizii 1966. 101. 
${ }^{11}$ Leonid Brezhnev. "Report of the Central Committee of the Communist Party of the Soviet Union to the $24^{\text {th }}$ Congress of the CPSU" in $24^{\text {th }}$ Congress of the Communist Party of the Soviet Union March 30 - April 9, 1971, Documents. Moscow: Novosti Press Agency Publishing House, 1971. 47-48.

${ }^{12}$ Brezhnev, "Report to the $24^{\text {th }}$ CPSU Congress", 87.

${ }_{14}^{13}$ Brezhnev, "Report to the $24^{\text {th }}$ CPSU Congress", 91-92.

${ }^{14}$ Alfred B. Evans, Jr. "Developed Socialism in Soviet Ideology”. Soviet Studies, Vol. 29, No. 3 (July 1977). 411 414.

${ }^{15}$ Evans, Jr. "Developed Socialism in Soviet Ideology". 420-421.

${ }^{16}$ Antanas Snechkus. "Velikaia Sila Sotsialisticheskogo Internatsionalizma" in Kommunist No. 11 (1039) (July 1972). 20-21.

${ }^{17}$ Petr Masherov. “O Nekotorykh Chertakh i Osobennostiakh Natsional'nykh Otnoshenii v Usloviiakh Razvitogo Sotsializma" in Kommunist No. 15 (1043) (Oct. 1972). 15-33.

${ }^{18}$ N. Baibakov. "Ekonomika SSSR - Edinyi Narodnokhoziaistvennyi Kompleks" in Kommunist No. 16 (1044) Nov. 1972. 32-45.

${ }^{19}$ Aleksei Kosygin. "Sotsial'no-Ekonomicheskoe Razvitie Sovetskogo Mnogonatsional'nogo Gosudarstva" in Kommunist No. 17 (1045) (November 1972). 15-41.

\section{Chapter Four}

${ }^{1}$ T.U. Usubaliev. “Otchet Tsentral'nogo Komiteta Kompartii Kirgizii XV S"ezdu Kommunisticheskoi Partii Kirgizii" in XV S" ezd Kommunisticheskoi Partii Kirgizii, 3-5 Marta 1971 goda (Stenograficheskii Otchet). Frunze: Izdatel'stvo Kirgizstan, 1978. 16-66.

${ }^{2}$ T.U. Usubaliev. "Otchet Tsentral'nogo Komiteta Kompartii Kirgizii XVI S"ezdu Kommunisticheskoi Partii Kirgizii" in XV S" ezd Kommunisticheskoi Partii Kirgizii, 16-18 Ianvaria 1976 goda (Stenograficheskii Otchet). Frunze: Izdatel'stvo Kirgizstan, 1976. 22.

${ }^{3}$ Usubaliev, Report of the Central Committee to the XVI Kirgiz Communist Party Congress, 54-55.

${ }^{4}$ Usubaliev, Report of the Central Committee to the XVI Kirgiz Communist Party Congress, 55.

${ }^{5}$ Speech by K.G. Karakeev to the $16^{\text {th }}$ Kirgiz Party Congress in XV S" ezd Kommunisticheskoi Partii Kirgizii, 16-18 Ianvaria 1976 goda (Stenograficheskii Otchet). Frunze: Izdatel'stvo Kirgizstan, 1976. 149.

${ }^{6}$ Speech by S. Tabyshaliev to the $16^{\text {th }}$ Kirgiz Party Congress in XV S" ezd Kommunisticheskoi Partii Kirgizii, 16-18 Ianvaria 1976 goda (Stenograficheskii Otchet). Frunze: Izdatel'stvo Kirgizstan, 1976. 180.

${ }^{7}$ Speech by A. Dvisheev to the $16^{\text {th }}$ Kirgiz Party Congress in XV S" ezd Kommunisticheskoi Partii Kirgizii, 16-18 Ianvaria 1976 goda (Stenograficheskii Otchet). Frunze: Izdatel'stvo Kirgizstan, 1976. 129-130.

${ }^{8}$ Speech by N.G. Liashchenko to the $16^{\text {th }}$ Kirgiz Party Congress in XVI S" ezd Kommunisticheskoi Partii Kirgizii, 16-18 Ianvaria 1976 goda (Stenograficheskii Otchet). Frunze: Izdatel'stvo Kirgizstan, 1976. 189.

${ }^{9}$ T.U. Usubaliev. "Otchet Tsentral'nogo Komiteta Kompartii Kirgizii XVII S"ezdu Kommunisticheskoi Partii Kirgizii” in XVII S"ezd Kommunisticheskoi Partii Kirgizii, 20-22 Ianvaria 1981 goda (Stenograficheskii Otchet). Frunze: Izdatel'stvo Kirgizstan, 1981. 18.

${ }^{10}$ Bruce Weber. "Chingiz Aitmatov, Who Wrote of Life in U.S.S.R., Is Dead at 79." The New York Times (June 15, 2008). http://www.nytimes.com/2008/06/15/books/15aitmatov.html?ref=obituaries\&_r=0 (accessed July 12, 2014).

${ }^{11}$ Tyntchtykbek Tchoroev. "Chingiz Aitmatov's Lifelong Journey Toward Eternity". Radio Free Europe/Radio Liberty, December 12, 2008.

http://www.rferl.org/content/Chyngyz_Aitmatovs_Lifelong_Journey_Toward_Eternity/1359041.html (Accessed July 12, 2014).

${ }^{12}$ For additional information on the epic Manas, see Josh Wilson. "Manas: The Kyrgyz Odysseys, Moses and Washington" The School of Russian and Asian Studies http://www.sras.org/manas kyrgyz hero (accessed July 12, 2014).

${ }^{13}$ Speech by Chingiz Aitmatov to the $16^{\text {th }}$ Kirgiz Party Congress in XVI S"ezd Kommunisticheskoi Partii Kirgizii, 16-18 Ianvaria 1976 goda (Stenograficheskii Otchet). Frunze: Izdatel'stvo Kirgizstan, 1976. 115-116.

${ }^{14}$ Speech by Chingiz Aitmatov to the $17^{\text {th }}$ Kirgiz Party Congress in XVII S"ezd Kommunisticheskoi Partii Kirgizii, 20-22 Ianvaria 1981 goda (Stenograficheskii Otchet). Frunze: Izdatel'stvo Kirgizstan, 1981. 156-57.

${ }^{15}$ Moscow's efforts to tighten control - at least in a linguistic sense - in the Transcaucasian republics in 1977 will spark protests in Georgia, as will be explained later. Moreover, as I will discuss in the Conclusion, Gorbachev's action to replace the Kazakh Party First Secretary will also spark protests there in the 1980s. 
${ }^{16}$ Sharaf Rashidov. "Otchetnyi Doklad Tsentral'nogo Komiteta Kommunisticheskoi Partii Uzbekistana" in XIX S"ezd Kommunisticheskoi Partii Uzbekistana 3-5 Fevralia 1976 goda, Stenograficheskii Otchet. Tashkent:

Izdatel'stvo Uzbekistan, 1978. 15-73.

${ }^{17}$ Speech by K. Nugmanov to the $19^{\text {th }}$ Uzbek Party Congress in XIX S"ezd Kommunisticheskoi Partii Uzbekistana 3-5 Fevralia 1976 goda, Stenograficheskii Otchet. Tashkent: Izdatel'stvo Uzbekistan, 1978. 174.

${ }^{18}$ Sharaf Rashidov. "Leninskaia Natsional'naia Politika v Deistvii" in Kommunist No. 15 (1079) Oct. 1974. 49.

${ }^{19}$ Sharaf Rashidov. "Otchet Tsentral'nogo Komiteta Kommunisticheskoi Partii Uzbekistana XX S"ezdu Kommunisticheskoi Partii Uzbekistana" in XX S" ezd Kommunisticheskoi Partii Uzbekistana 3-5 Fevralia 1981 goda, Stenograficheskii Otchet. Tashkent: Uzbekistan, 1982. 16-72.

20 "Rezoliutsiia XX S" Uzbekistana" in XX S"ezd Kommunisticheskoi Partii Uzbekistana 3-5 Fevralia 1981 goda, Stenograficheskii Otchet. Tashkent: Uzbekistan, 1982. 213.

${ }^{21}$ Dzhabbor Rasulov. "Otchetnyi Doklad Tsentral'nogo Komiteta KP Tadzhikistana XVIII S"ezdu Kommunisticheskoi Partii Tadzhikistana" in XVIII S" ezdu Kommunisticheskoi Partii Tadzhikistana 27-29 Ianvariq 1976 goda, Stenograficheskii Otchet. Dushanbe: Irfon, 1977. 63-66.

${ }^{22}$ R.D. Dadaboev Speech to the $18^{\text {th }}$ Tajik Party Congress in in XVIII S"ezdu Kommunisticheskoi Partii Tadzhikistana 27-29 Ianvariq 1976 goda, Stenograficheskii Otchet. Dushanbe: Irfon, 1977. 242.

${ }^{23} \mathrm{M}$. Tursun-zade Speech to the $18^{\text {th }}$ Tajik Party Congress in in XVIII S"ezdu Kommunisticheskoi Partii Tadzhikistana 27-29 Ianvariq 1976 goda, Stenograficheskii Otchet. Dushanbe: Irfon, 1977. 124.

24 “Rezoliutsiia XVIII S"ezda Kommunisticheskoi Partii Tadzhikistana po Otchetnomu Dokladu TsK KP Tadzhikistana" in XVIII S"ezdu Kommunisticheskoi Partii Tadzhikistana 27-29 Ianvariq 1976 goda, Stenograficheskii Otchet. Dushanbe: Irfon, 1977. 286-287.

${ }^{25}$ Dzhabbor Rasulov. "Otchetnyi Doklad Tsentral'nogo Komiteta KP Tadzhikistana XIX S"ezdu Kommunisticheskoi Partii Tadzhikistana" in XIX S"ezdu Kommunisticheskoi Partii Tadzhikistana 23-25 Ianvariq 1981 goda, Stenograficheskii Otchet. Dushanbe: Irfon, 1983.

${ }^{26}$ James Critchlow. Nationalism in Uzbekistan: A Soviet Republic's Road to Sovereignty. Boulder: Westview Press, 1991. 20.

${ }^{27}$ James Critchlow, Nationalism in Uzbekistan, 20.

${ }^{28}$ James Critchlow, Nationalism in Uzbekistan, 22-24.

${ }^{29}$ Petro Shelest. "Otchet Tsentral'nogo Komiteta KP Ukrainy XXIV S"ezdu Kommunisticheskoi Partii Ukrainy” in XXIV S”ezd Kommunisticheskoi Partii Ukrainy 17-20 Marta 1971 goda, Stenograficheskii Otchet. Kiev: Izdatel'stvo Politicheskoi Literatury Ukrainy, 1972. 17-77.

${ }^{30}$ Speech by Iu. K. Smolich to the $24^{\text {th }}$ Ukrainian Party Congress in XXIV S"ezd Kommunisticheskoi Partii Ukrainy 17-20 Marta 1971 goda, Stenograficheskii Otchet. Kiev: Izdatel'stvo Politicheskoi Literatury Ukrainy, 1972. 154158.

${ }^{31}$ Petro Shelest. Da ne Sudimy Budete: Dnevnikovye Zapisi, Vospominaniia Chlena Politbiuro TsK KPSS. Moscow: Kvintessentsiia, 1995. 249-250.

${ }^{32}$ Shelest, Da ne Sudimy Budete, 251.

${ }^{33}$ Nahaylo \& Swoboda, Soviet Disunion, 150.

${ }^{34}$ Nahaylo \& Swoboda, Soviet Disunion, 150-151.

${ }^{35}$ The NTS refers to the National Alliance of Russian Solidarists (Narodno-Trudovoi Soiuz Rossiiskikh Solidaristov) which formed in 1930 as a group of right-wing Russian nationalists who opposed Communism. Shelest states that this group is active in Ukraine and other parts of the USSR. Revealingly, Brezhnev noted during Shelest's speech at this March 1972 Politburo meeting that "in western Ukraine, Bandera and OUN members are raising their heads and that 50,000 of them are living there." Thus, Shelest points out that Russian nationalists are very active and also admits to the activities of Ukrainian nationalists, yet Brezhnev ignores the Russian nationalist activities.

${ }^{36}$ Shelest, Da ne Sudimy Budete, 504-505.

${ }^{37}$ Shelest, Da ne Sudimy Budete, 505.

${ }^{38}$ It is interesting to contrast Shelest's opinion of Shcherbitskii with that of Mikhail Gorbachev. In a diary entry dated 7 October 1965, Shelest writes that Shcherbitskii "was a discourteous man in party relations, uncultured, rude, bold in dealing with comrades, and a big whiner." On the other hand, in his Memoirs, Gorbachev states "Although Shcherbitskii's personality was not extraordinary, he commanded prestige as someone who 'led' his republic firmly. Even more important, he was, in his own words, a steadfast follower of Bogdan Khmelnitsky: a symbol of Ukraine's 
unity with Russia." (Mikhail Gorbachev, Memoirs, 125-126). Of course politics play a major role in these very different views of Shcherbitskii - he was Shelest's main political rival while Gorbachev saw him as an ally during his own rise in the ranks in the late 1970s. But this is also evidence of Shelest's and Gorbachev's different views on the Soviet nationality issue. Shelest favored greater decentralization of power to the republics, while Gorbachev tended to be more centrist in his outlook at least until events after 1989 forced his hand.

${ }^{39}$ Nahaylo \& Swoboda, Soviet Disunion, 163.

40 John Keep, The Last of the Empires, 159-160.

${ }^{41}$ Yegor Ligachev. Inside Gorbachev's Kremlin: The Memoirs of Yegor Ligachev. Introduction by Stephen F. Cohen. Tr. Catherine A. Fitzpatrick, Michele A. Berdy \& Dobrochna Dyrcz-Freeman. New York: Pantheon Books, 1993. 210-220.

42 John Keep, The Last of the Empires, 309.

${ }^{43}$ Mikhail Gorbachev. Memoirs. New York: Doubleday, 1995, 125-126, 145.

${ }^{44}$ Volodymyr Shcherbitskii. “Otchet Tsentral'nogo Komiteta Kompartii Ukrainy XXV S”ezdu Kommunisticheskoi Partii Ukrainy” in XXV S”ezd Kommunisticheskoi Partii Ukrainy 10-13 Fevralia 1976 goda, Stenograficheskii Otchet. Kiev: Izdatel'stvo Politicheskoi Literatury Ukrainy, 1976. 17-79.

\section{Chapter Five}

1 "The Final Act of the Conference on Security and Cooperation in Europe, August 1, 1975". http://www1.umn.edu/humanrts/osce/basics/finact75.htm (accessed March 23, 2015).

${ }^{2}$ Aldis Purs. Baltic Facades: Estonia, Latvia, and Lithuania since 1945. London: Reaktion Books, 2012.22.

${ }^{3}$ Kristian Gerner \& Stefan Hedlund. The Baltic States and the End of the Soviet Empire. London: Routledge, 1993. 51-54.

${ }^{4}$ Romuald J. Misiunas \& Rein Taagepera. The Baltic States Years of Dependence, 1940-1990. Expanded and Updated Edition. Berkeley: University of California Press, 1993. 15-16.

${ }^{5}$ Misiunas \& Taagepera, Years of Dependence, 21.

${ }^{6}$ Misiunas \& Taagepera, Years of Dependence, 23.

${ }^{7}$ Misiunas \& Taagepera, Years of Dependence, 25.

${ }^{8}$ Misiunas \& Taagepera, Years of Dependence, 28-29.

${ }^{9}$ Misiunas \& Taagepera, Years of Dependence, 42.

${ }^{10}$ Misiunas \& Taagepera, Years of Dependence, 42.

${ }^{11}$ Misiunas \& Taagepera, Years of Dependence, 46-47.

${ }^{12}$ Misiunas \& Taagepera, Years of Dependence, 73.

${ }^{13}$ Misiunas \& Taagepera, Years of Dependence, 73.

${ }^{14}$ Misiunas \& Taagepera, Years of Dependence, 83-91.

${ }^{15}$ Ingrida Kalnins, Ed. The Baltic Tribunal Against the Soviet Union, July 25 \& 26, 1985. Rockville, MD: The World Federation of Free Latvians, 1985. 32.

${ }^{16}$ Alistair Horne. A Savage War of Peace: Algeria 1954-1962. New York: The New York Review of Books, 2006. 23-30.

${ }^{17}$ Purs, Baltic Facades, 73.

${ }_{18}^{18}$ Misiunas \& Taagepera, Years of Dependence, 78.

${ }^{19}$ Violeta Davoliute. "Postwar Reconstruction and the Imperial Sublime in Vilnius during Late Stalinism". $A b$ Imperio (1/2014). 177-178.

${ }^{20}$ Davoliute, "Post War Reconstruction and the Imperial Sublime", 186-187.

${ }^{21}$ Davoliute, "Post War Reconstruction and the Imperial Sublime", 194. On song festivals in the Baltic republics, see also Alexeyeva, Soviet Dissent; Misiunas \& Taagepera, Years of Dependence, 177-178.

${ }^{22}$ Alexeyeva, Soviet Dissent, 64.

${ }^{23}$ Epp Annus. "The Problem of Soviet Colonialism in the Baltics." Journal of Baltic Studies, Vol. 43, No.1 (March 2012). 36.

${ }^{24}$ Kalnins, The Baltic Tribunal, 1.

${ }^{25}$ Kalnins, The Baltic Tribunal, 7-8.

${ }^{26}$ Kalnins, The Baltic Tribunal, 39.

${ }^{27}$ Kalnins, The Baltic Tribunal, 130-137. 
${ }^{28}$ Kalnins, The Baltic Tribunal, 160-162.

${ }^{29}$ A Chronicle of Current Events. Issue 20 (2 July 1971). Amnesty International. 232-234.

${ }^{30}$ A Chronicle of Current Events. Issue 29 (31 July 1973). Amnesty International. 69-70.

${ }^{31}$ A Chronicle of Current Events. Issue 26 (October 1972). Amnesty International. 248-250.

${ }^{32}$ A Chronicle of Current Events. Issue 44 (16 March 1977). Amnesty International. 161.

${ }^{33}$ For information on both demonstrations in October 1977, see A Chronicle of Current Events, Issue 47 (30

November 1977). Amnesty International. 50-51.

${ }^{34}$ A Chronicle of Current Events. Issue 47 (30 November 1977). Amnesty International. 51.

${ }^{35}$ Kestutis K. Girnius. "Catholicism and Nationalism in Lithuania" in Religion and Nationalism in Soviet and East European Politics. Ed. Pedro Ramet. Durham, NC: Duke University Press, 1989. 109.

${ }^{36}$ For an in-depth review of Soviet efforts to bring the Catholic Church in Lithuania under its control, see "The Origin and Aims of The Chronicle of the Catholic Church in Lithuania" http://lkbkronika.lt/en/index.php?option=com_content\&view=article\&id=344\&Itemid=229

37 "The Origin and Aims of The Chronicle of the Catholic Church in Lithuania"

${ }^{38}$ For the full text of this letter, see Chronicle of the Catholic Church in Lithuania. No. 21. Brooklyn, NY:

Lithuanian Roman Catholic Priests' League of America, 1978. 26-43.

${ }^{39}$ Liudmila Alexeyeva. Soviet Dissent: Contemporary Movements for National, Religious, and Human Rights. Carol Pearce \& John Glad, Tr. Middletown, Conn.: Wesleyan University Press, 1985. 98.

${ }^{40}$ Alexeyeva, Soviet Dissent, 7.

${ }^{41}$ Alexeyeva, Soviet Dissent, 31-33.

${ }^{42}$ Orest Subtelny. Ukraine: A History Second Edition. Toronto: University of Toronto Press, 1994. 516.

${ }^{43}$ Subtelny. Ukraine, 516.

${ }^{44}$ Subtelny, Ukraine, 517.

${ }^{45}$ Alexeyeva, Soviet Dissent, 34.

${ }^{46}$ Ivan Dziuba. Internationalism or Russification? A Study in the Soviet Nationalities Problem. M. Davies, Ed. London: Weidenfeld and Nicolson, 1970. 13-15.

${ }^{47}$ Dziuba, Internationalism or Russification?, 40-43.

${ }^{48}$ Dziuba, Internationalism or Russification?, 45.

${ }^{49}$ Dziuba, Internationalism or Russification?, 90.

${ }^{50}$ Dziuba, Internationalism or Russification?, 128-129.

${ }^{51}$ Dziuba, Internationalism or Russification?, 135-138.

${ }^{52}$ Stephen Velychenko. "Ukrainian Anticolonialist Thought in Comparative Perspective: A Preliminary Overview." Ab Imperio, 4/2012. 339-350.

${ }^{53}$ On Ho Chi Minh's political background and his intellectual development, see Jean Lacouture. Ho Chi Minh: A Political Biography. Tr. Peter Wiles \& Jane Clark Seitz. New York: Random House, 1968. Lacouture provides a concise biographical sketch of Ho, though treats his Marxist-Leninist leanings with disdain. See also Chapter 6 in James P. Harrison. The Endless War: Vietnam's Struggle for Independence. New York: Columbia University Press, 1989. A more detailed account of Ho's formative years can be found in William J. Duiker. Ho Chi Minh: A Life. New York: Hachette Books, 2012.

${ }^{54}$ Ho Chi Minh. "Report on the Draft Amended Constitution" in Ho Chi Minh: Selected Writings 1920-1969. Hanoi: Foreign Languages Publishing House, 1973. 210-214.

${ }^{55}$ On Nkrumah, see Ali A. Mazrui. "Nkrumah: The Leninist Czar". Transition, No. 75/76 (1997). 106-126. On M.N. Roy, see for example his essay "The $2^{\text {nd }}$ International and the Doctrine of Self-Determination". Communist International (New Series). No. 4 (1924). Available at https://www.marxists.org/archive/roy/1924/x01/x01.htm For an overview of Communism and its influence in the Third World, see Raymond Duncan. "Ideology and Nationalism in Attracting Third World Leaders to Communism: Trends and Issues in the Late Twentieth Century". World Affairs, Vol. 151, No. 3 (Winter 1988-1989). 105-116.

${ }^{56}$ Alexander Keese. "A Culture of Panic: 'Communist' Scapegoats and Decolonization in French West Africa and French Polynesia (1945-1957).” French Colonial History, Vol. 9 (2008). 131-145.

${ }_{57}^{57}$ Alexeyeva, Soviet Dissent, 29-30.

${ }^{58}$ Alexeyeva, Soviet Dissent, 30.

${ }^{59}$ A Chronicle of Current Events. Issue 18 (March 1971). Amnesty International. 111-112.

${ }^{60}$ A Chronicle of Current Events. Issue 18 (March 1971). Amnesty International. 116-117.

${ }^{61}$ Alexeyeva, Soviet Dissent, 38. 
${ }^{62}$ A Chronicle of Current Events. Issue 26 (5 July 1972). 243.

${ }^{63}$ A Chronicle of Current Events. Issue 24 (5 March 1972). 124-126.

${ }^{64}$ A Chronicle of Current Events. Issue 26 (5 July 1972). 244-245.

${ }^{65}$ Valentyn Moroz speech to the National Press Club quoted in Christian Peterson. Routledge Studies on History and Globalization: Globalizing Human Rights: Private Citizens, the Soviet Union, and the West. New York: Routledge, 2012. 95.

${ }^{66}$ Charles King. The Moldovans: Romania, Russia, and the Politics of Culture. Stanford: Hoover Institution Press, 2000. 2-3.

${ }^{67}$ Charles King, The Moldovans, 3.

${ }^{68}$ Charles King, The Moldovans, 63.

${ }^{69}$ Charles King, The Moldovans, 91-95.

${ }^{70}$ Charles King, The Moldovans, 96-99. The large proportion of Ukrainians in the Moldavian Communist Party presents another wrinkle in the multinational relations of the Soviet Union. While Ukrainian dissidents and even some Ukrainian Party members decried the colonial nature of the Ukrainian SSR (as discussed earlier in this chapter), many Ukrainians were also collaborators in the Soviet imperial project.

${ }^{71}$ Charles King, The Moldovans, 115.

${ }^{72}$ Charles King, The Moldovans, 104-107.

${ }^{73}$ A Chronicle of Current Events. Issue 43 (31 December 1976). 19.

${ }^{74}$ A Chronicle of Current Events. Issue 17 (April 1971). 73.

${ }^{75}$ On this, see Charles King, The Moldovans, 145-160.

${ }^{76}$ On this, see Vladimir Potseluev. Gerby Soiuza SSR: Iz Istorii Razrabotki. Moscow: Izdatel'stvo Politicheskoi Literatury, 1987. 73-78.

${ }_{77}^{77}$ Richard Pipes, The Formation of the Soviet Union, 101-102.

${ }^{78}$ Alexeyeva, Soviet Dissent, 124.

${ }^{79}$ Alexeyeva, Soviet Dissent, 125.

${ }^{80}$ A Chronicle of Current Events. Issue 45 (25 May 1977). 260.

${ }^{81}$ For the details on Ayrikyan's trial, see A Chronicle of Current Events. Issue 34 (31 December 1974). 12-14.

${ }^{82}$ The complete text of the letter can be found in A Chronicle of Current Events. Issue 44 (16 March 1977). 141142.

${ }^{83}$ CIA National Intelligence Council. "Dimensions of Civil Unrest in the Soviet Union." April 1983. Freedom of Information Act Electronic Reading Room. http://www.foia.cia.gov/

84 "Dimensions of Civil Unrest in the Soviet Union", 10-16.

${ }^{85}$ On the tactics of repression, see issues of A Chronicle of Current Events. Every issue in the 1960s and 1970s provides examples of the use of repression. See also Alexeyeva, Soviet Dissent, Nahaylo \& Swoboda Soviet Disunion, and Peterson Globalizing Human Rights among numerous other works on the subject.

86 "Stasi Note on Meeting with KGB Officials, 13 November 1969", November 13, 1969, History and Public Policy Program Digital Archive, Office of the Federal Commissioner for the Stasi Records (BStU), MfS, MfS, SdM 577, p. 88-110. Translated from German for CWIHP by Bernd Schaefer.

http://digitalarchive.wilsoncenter.org/document/115714

87 "Report of the Chairman of the Committee for State Security of the Armenian Socialist Soviet Republic M.A. Yuzbashyan," March 14, 1979, History and Public Policy Program Digital Archive, Armenian National Archives. Tr. Svetlana Savranskaya. http://digitalarchive.wilsoncenter.org/document/117341

88 "O dopolnitel'nykh merakh po protivodeistviiu antisovetskoi deiatel'nosti ukrainskikh burzhuaznonatsionalisticheskikh organizatsii za rubezhom." Bukovsky Archive http://bukovsky-archives.net 89 "FY-85 Approval of Operational Activity QRDYNAMIC". Freedom of Information Act Electronic Reading Room. http://www.foia.cia.gov/

${ }^{90}$ CIA Directorate of Intelligence. "The Soviet View of the Dissident Problem Since Helsinki” May 1977. Freedom of Information Act Electronic Reading Room. http://www.foia.cia.gov/

${ }^{91}$ Christian Peterson, Globalizing Human Rights, 75.

${ }^{92}$ CIA, "The Soviet View of the Dissident Problem" May 1977.

${ }_{93}^{93}$ Peterson, Globalizing Human Rights, 76.

${ }^{94}$ Klaas Van Walraven. "Decolonization by Referendum: The Anomaly of Niger and the Fall of Sawaba, 19581959." The Journal of African History, Vol. 50, No. 2 (2009). 269.

${ }^{95}$ Klaas Van Walraven, "Decolonization by Referendum", 270. 
96 “'Committee for State Security Report, 'On the Results of Search for Authors of Anti-Soviet Anonymous Documents in 1975'”, March 13, 1976. History and Public Policy Program Digital Archive, US Library of Congress, Manuscript Division, Dmitrii A. Volkogonov Papers, Reel 18, Container 28. Tr. Brian Bachor \& Svetlana Savranskaya. http://digitalarchive.wilsoncenter.org/document/121195.

\section{Chapter Six}

${ }^{1}$ Obviously the 1936 USSR Constitution was amended to reflect the acquisition of the three Baltic Republics and Moldavia in 1940, but for the sake of simplicity, I will refer to it as the 1936 USSR Constitution.

${ }^{2}$ Konstitutsiia (Osnovnoi Zakon) SSS; Konstitutsiia (Osnovnye Zakony) Soiuznykh i Avtonomnykh Sovetskikh Sotsialisticheskikh Respublik. Moscow: Gosudarstvennoe Izdatel'stvo Iuridicheskoi Literatury, 1960. 5. All references to the 1936 USSR Constitution come from this source. Hereafter, this will simply be referred to as Konstitutsiia 1960.

${ }^{3}$ Brezhnev speech to the May 1977 Plenum from Materialy Plenumov TsK KPSS 8 Apreliq 1966 g. - 18 Fevralia 1986. Fond 2, opis' 3, film roll 171, delo 428.

${ }^{4}$ Brezhnev speech to the May 1977 Plenum from Materialy Plenumov TsK KPSS 8 Apreliq 1966 g. - 18 Fevralia 1986. Fond 2, opis' 3, film roll 171, delo 428.

${ }^{5}$ Brezhnev speech to the May 1977 Plenum from Materialy Plenumov TsK KPSS 8 Apreliq 1966 g. - 18 Fevralia 1986. Fond 2, opis' 3, film roll 171, delo 428.

${ }^{6}$ Brezhnev speech to the May 1977 Plenum from Materialy Plenumov TsK KPSS 8 Apreliq 1966 g. - 18 Fevralia 1986. Fond 2, opis' 3, film roll 171, delo 428.

${ }^{7}$ Brezhnev speech to the May 1977 Plenum from Materialy Plenumov TsK KPSS 8 Apreliq 1966 g. - 18 Fevralia 1986. Fond 2, opis' 3, film roll 171, delo 428.

${ }^{8}$ Brezhnev speech to the May 1977 Plenum from Materialy Plenumov TsK KPSS 8 Apreliq 1966 g. - 18 Fevralia 1986. Fond 2, opis' 3, film roll 171, delo 428.

${ }^{9}$ The Preamble to the 1977 USSR Constitution will be discussed in detail below.

101977 Draft Constitution from Materialy Plenumov TsK KPSS 8 Apreliq 1966 g. - 18 Fevralia 1986. Fond 2, opis' 3, film roll 171, delo 428 .

${ }^{11}$ Letter from N.A. Shchelokov to the Constitutional Commission of the Central Committee from Materialy Plenumov TsK KPSS 8 Apreliq 1966 g. - 18 Fevralia 1986. Fond 2, opis' 3, film roll 171, delo 428.

121977 Draft Constitution from Materialy Plenumov TsK KPSS 8 Apreliq 1966 g. - 18 Fevralia 1986. Fond 2, opis' 3 , film roll 171, delo 428 .

${ }^{13}$ K.F. Il'iashenko "Explanation of the Proposed Presentations in Articles 162 and 164" from Materialy Plenumov TsK KPSS 8 Apreliq 1966 g. - 18 Fevralia 1986. Fond 2, opis' 3, film roll 171, delo 428.

1414 K.F. Il'iashenko "Explanation of the Proposed Presentations in Articles 162 and 164" from Materialy Plenumov TsK KPSS 8 Apreliq 1966 g. - 18 Fevralia 1986. Fond 2, opis' 3, film roll 171, delo 428.

${ }^{15}$ Letter from F. Shamsudinov, First Secretary of Fergana Oblast Party Committee from Materialy Plenumov TsK KPSS 8 Apreliq 1966 g. - 18 Fevralia 1986. Fond 2, opis' 3, film roll 171, delo 428.

${ }^{16}$ Speech by M.M. Musakhanov to the May 1977 Central Committee Plenum from Materialy Plenumov TsK KPSS 8 Apreliq 1966 g. - 18 Fevralia 1986. Fond 2, opis' 3, film roll 171, delo 428.

${ }^{17}$ Speech by V.V. Shcherbitskii to the May 1977 Central Committee Plenum from Materialy Plenumov TsK KPSS 8 Apreliq 1966 g. - 18 Fevralia 1986. Fond 2, opis' 3, film roll 171, delo 428.

${ }^{18}$ Speech by E.N. Auel'bekov to the May 1977 Central Committee Plenum from Materialy Plenumov TsK KPSS 8 Apreliq 1966 g. - 18 Fevralia 1986. Fond 2, opis' 3, film roll 171, delo 428.

${ }^{19}$ As in the previous section of this chapter, all references to the 1936 constitutions are from Konstitutsiia (Osnovnoi Zakon) SSS; Konstitutsiia (Osnovnye Zakony) Soiuznykh i Avtonomnykh Sovetskikh Sotsialisticheskikh Respublik. Moscow: Gosudarstvennoe Izdatel'stvo Iuridicheskoi Literatury, 1960.

${ }^{20}$ P.G. Pikhoia. Sovetskii Soiuz: Istoriia Vlasti 1945-1991. Moscow: Izdatel'stvo RAGS, 1998. 368-369.

${ }^{21}$ Ronald Grigor Suny. The Making of the Georgian Nation Second Edition. Bloomington: Indiana University Press, 1994. 


\section{Chapter Seven}

${ }^{1}$ Joseph Hodge, Triumph of the Expert, 208.

${ }^{2}$ The details of the East Africa Groundnut Scheme are found in Hodge, Triumph of the Expert, 210.

${ }^{3}$ Hodge, Triumph of the Expert, 213.

${ }^{4}$ Hodge, Triumph of the Expert, 215.

${ }^{5}$ Hodge, Triumph of the Expert, 215-216.

${ }^{6}$ Hodge, Triumph of the Expert, 220-221.

${ }^{7}$ Christopher J. Ward. Brezhnev's Folly: The Building of BAM and Late Soviet Socialism. Pittsburgh: University of Pittsburgh Press, 2009. 2.

${ }^{8}$ Ward, Brezhnev's Folly, 11.

${ }^{9}$ Ward, Brezhnev's Folly, 98.

${ }^{10}$ Ward, Brezhnev's Folly, 99.

${ }^{11}$ Ward, Brezhnev's Folly, 125.

${ }^{12}$ Philip P. Micklin. "Desiccation of the Aral Sea: A Water Management Disaster in the Soviet Union" Science, New Series, Vol. 241, No. 4870 (Sept. 2, 1988). 1170-1171.

${ }^{13}$ John Staples. "Soviet Use of Corruption Purges as a Control Mechanism: The Uzbekistan Case" Past Imperfect Vol. 2 (1993). 36-37.

${ }^{14}$ Staples, "Soviet Use of Corruption Purges", 35.

${ }^{15}$ Yaacov Ro'i. Islam in the Soviet Union, 104-105.

${ }^{16}$ Martha Brill Olcott. "Roots of Radical Islam in Central Asia" Carnegie Papers No. 77 (January 2007). 6.

${ }^{17}$ Martha Brill Olcott, "Roots of Radical Islam", 7.

${ }^{18}$ Martha Brill Olcott, "Roots of Radical Islam", 11.

${ }^{19}$ On Hindustani's curriculum, see Olcott "Roots of Radical Islam" p. 11 and see also Vitaly V. Naumkin. Radical Islam in Central Asia: Between Pen and Rifle. Lanham, MD: Rowman \& Littlefield Publishers, 2005. 50-51.

${ }^{20}$ Martha Brill Olcott, "Roots of Radical Islam", 13.

${ }^{21}$ Martha Brill Olcott, "Roots of Radical Islam", 4.

${ }^{22}$ Vitaly Naumkin, Radical Islam in Central Asia, 54-55.

${ }^{23}$ Yaacov Ro'i. Islam in the Soviet Union, 583-584.

${ }^{24}$ N. Ashirov. Islam i Natsii. Moscow: Izdatel'stvo Politicheskoi Literatury, 1975. 74-84.

${ }^{25}$ Ashirov, Islam i Natsii, 107-130.

${ }^{26}$ Odd Arne Westad. The Global Cold War: Third World Interventions and the Making of Our Times. Cambridge: Cambridge University Press, 2007. 169-170.

${ }^{27}$ Mark Webber. "'Out of Area' Operations: The Third World" in Brezhnev Reconsidered. Edwin Bacon \& Mark Sandle, Eds. New York: Palgrave MacMillan, 2002. 110-116.

${ }_{28}^{28}$ Mike Bowker. "Brezhnev and Superpower Relations" in Brezhnev Reconsidered. Edwin Bacon \& Mark Sandle, Eds. New York: Palgrave MacMillan, 2002. 90-92.

${ }^{29}$ Vladislav M. Zubok. A Failed Empire: The Soviet Union in the Cold War from Stalin to Gorbachev. Chapel Hill: UNC Press, 2007. 203.

${ }^{30}$ Zubok, A Failed Empire, 200.

31 "Information of KGB USSR to CC CPSU International Department, 10 October 1979". Cold War International History Project Bulletin (Winter 1996/1997). Washington, DC: Woodrow Wilson International Center for Scholars. 157.

${ }^{32}$ Zubok, A Failed Empire, 260.

${ }^{33}$ Pikhoia, Sovetskii Soiuz: Istoriia Vlasti, 399.

${ }^{34}$ L.I. Brezhnev. "Otchet Tsentral'nogo Komiteta KPSS XXVI S"ezdu Kommunisticheskoi Partii Sovetskogo Soiuza i Ocherednye Zadachi Partii v Oblasti Vnutrennei i Vneshnei Politiki" in XXVI S"ezd Kommunisticheskoi Partii Sovetskogo Soiuza 23 Fevralia - 3 Marta 1981 goda, Stenograficheskii Otchet. Moscow: Izdatel'stvo Politichskoi Literatury, 1981. 30-31.

${ }^{35}$ Rasma Karklins. "Islam: How Strong Is It in the Soviet Union?" Cahiers du Monde russe et sovietique, Vol. 21, No. 1 (Jan.-Mar. 1980). 66.

${ }^{36}$ Suny, The Making of the Georgian Nation, 306. 
${ }^{37}$ Tamara Dragadze. “Azerbaijanis” in The Nationalities Question in the Soviet Union Graham Smith, Ed. London: Longman, 1990. 168.

${ }^{38}$ For census data, see the relevant entries for each republic in D.I. Valentei, et.al., Eds. Demograficheskii Entsiklopedicheskii Slovar'. Moscow: Sovetskaia Entsiklopediia, 1985.

\section{Conclusion}

${ }^{1}$ L.I. Brezhnev. "47-ia Godovshchina Velikoi Oktiabr'skoi Sotsialisticheskoi Revoliutsii” in L.I. Brezhnev. Izbrannye Proizvedeniia v Trekh Tomakh, Tom. I 1964-1970. Moscow: Izdatel'stvo Politicheskoi Literatury, 1981. 11-20.

${ }^{2}$ Gorbachev, Memoirs, 326.

${ }^{3}$ Gorbachev, Memoirs, 328 .

${ }^{4}$ John Keep, The Last of the Empires, 384.

${ }^{5}$ John Keep, The Last of the Empires, 364.

${ }^{6}$ Gorbachev, Memoirs, 330.

${ }^{7}$ Ingvar Svanberg. "Kazakhs" in The Nationalities Question in the Soviet Union Graham Smith, Ed. London: Longman, 1990. 202.

${ }^{8}$ Gorbachev, Memoirs, 330-331.

${ }^{9}$ Gorbachev, Memoirs, 343-345. 


\section{Bibliography}

A Chronicle of Current Events. Various issues. Amnesty International.

Alexeyeva, Liudmila. Soviet Dissent: Contemporary Movements for National, Religious, and Human Rights. Carol Pearce \& John Glad, Tr. Middletown, Conn.: Wesleyan University Press, 1985.

Anderson, Benedict. Imagined Communities: Reflections on the Origin and Spread of Nationalism. (London: Verso, 1991).

Annus, Epp. "The Problem of Soviet Colonialism in the Baltics." Journal of Baltic Studies, Vol. 43, No.1 (March 2012).

Armstrong, John A. "Collaborationism in World War II: The Integral Nationalist Variant in Eastern Europe.” The Journal of Modern History Vol. 40, No. 3 (Sept. 1968).

Ashirov, N. Islam i Natsii. (Moscow: Izdatel'stvo Politicheskoi Literatury, 1975).

Baibakov, N. "Ekonomika SSSR - Edinyi Narodnokhoziaistvennyi Kompleks," Kommunist, No. 16 (1044) (Nov. 1972).

Berkhoff, Karel \& Marko Carynnyk. "The Organization of Ukrainian Nationalists and Its Attitude Toward Germans and Jews: Iaroslav Stets'ko’s 1941 Zhyttiepys.” Harvard Ukrainian Studies Vol.23, No. 3/4 (December 1999).

Bowker, Mike. "Brezhnev and Superpower Relations," Brezhnev Reconsidered Eds. Edwin Bacon \& Mark Sandle. (New York: Palgrave MacMillan, 2002).

Brandenberger, David \& Mikhail V. Zelenov. "Stalin's Answer to the National Question: A Case Study on the Editing of the 1938 Short Course". Slavic Review, Vol.73, No. 4 (Winter 2014).

Breslauer, George. Khrushchev and Brezhnev as Leaders: Building Authority in Soviet Politics. (London: George, Allen \& Unwin, 1982).

Brezhnev, Leonid. 'Rech' na Konferentsii Evropeiskikh Kommunisticheskikh i Rabochikh Partii, 24 Apreliu 1967 goda," L.I. Brezhnev: Izbrannye Proizvedeniia v Trekh Tomakh, Tom I: 1964-1970. (Moscow: Izdatel'stvo Politicheskoi Literatury, 1981).

. "Report of the Central Committee of the Communist Party of the Soviet Union to the $24^{\text {th }}$ Congress of the CPSU," $24^{\text {th }}$ Congress of the Communist Party of the Soviet Union March 30-April 9, 1971, Documents. (Moscow: Novosti Press Agency Publishing House, 1971). 
"Brezhnev's Speech on Anniversary of the Revolution," Current Digest of the Soviet Press, Vol. XVL, No. 43 (Nov. 18, 1964). 4.

Brzezinski, Zbigniew K. The Soviet Bloc: Unity and Conflict. Cambridge: Harvard University Press, 1967.

Bunce, Valerie \& John M. Echols, III. 'Soviet Politics in the Brezhnev Era: 'Pluralism' or 'Corporatism'?" Soviet Politics in the Brezhnev Era Ed. Donald R. Kelley. (New York: Praeger Publishers, 1980).

Chafer, Tony. The End of Empire in French West Africa: France's Successful Decolonization? (Oxford: Berg, 2002).

Chronicle of the Catholic Church in Lithuania. No. 21. Brooklyn, NY: Lithuanian Roman Catholic Priests' League of America, 1978.

CIA Directorate of Intelligence. "The Soviet View of the Dissident Problem Since Helsinki" May 1977. Freedom of Information Act Electronic Reading Room. http://www.foia.cia.gov/

CIA National Intelligence Council. "Dimensions of Civil Unrest in the Soviet Union." April 1983. Freedom of Information Act Electronic Reading Room. http://www.foia.cia.gov/

"Committee for State Security Report, 'On the Results of Search for Authors of Anti-Soviet Anonymous Documents in 1975'”, March 13, 1976. History and Public Policy Program Digital Archive, US Library of Congress, Manuscript Division, Dmitrii A. Volkogonov Papers, Reel 18, Container 28. Tr. Brian Bachor \& Svetlana Savranskaya. http://digitalarchive.wilsoncenter.org/document/121195.

Copland, Ian. The Princes of India in the Endgame of Empire, 1917-1947. Cambridge: Cambridge University Press, 1997.

Critchlow, James. Nationalism in Uzbekistan: A Soviet Republic's Road to Sovereignty. (Boulder: Westview Press, 1991).

Darwin, John. "Imperialism and the Victorians: The Dynamics of Territorial Expansion," The English Historical Review, Vol. 112, No. 447 (June 1997).

Davoliute, Violeta. "Postwar Reconstruction and the Imperial Sublime in Vilnius during Late Stalinism". Ab Imperio (1/2014).

Doyle, Michael W. Empires. (Ithaca: Cornell University Press, 1986).

Dragadze, Tamara. "Azerbaijanis," The Nationalities Question in the Soviet Union Ed. Graham Smith. (London: Longman, 1990). 
Duiker, William J. Ho Chi Minh: A Life. New York: Hachette Books, 2012.

Duncan, Raymond. "Ideology and Nationalism in Attracting Third World Leaders to Communism: Trends and Issues in the Late Twentieth Century". World Affairs, Vol. 151, No. 3 (Winter 1988-1989).

Dzhunusov, M.S. 'Natsiia kak sotsial'no-etnicheskaia Obshchnost' Liudei," Voprosy Istorii (April 1966).

Dziuba, Ivan. Internationalism or Russification? A Study in the Soviet Nationalities Problem. M. Davies, Ed. London: Weidenfeld and Nicolson, 1970.

Encausse, Helene Carrere. The Great Challenge: Nationalities and the Bolshevik State 19171930 Tr. Nancy Festinger. (New York: Holmes \& Meier, 1992).

--------------------. "When the Prison of Peoples was Opened," The Soviet Nationality Reader: The Disintegration in Context Ed. Rachel Denber. (Boulder: Westview Press, 1992).

Decline of an Empire: The Soviet Socialist Republics in Revolt. (New York: Newsweek Books, 1979).

Evans, Alfred Jr. "Developed Socialism in Soviet Ideology," Soviet Studies, Vol. 29, No. 3 (July 1977). 411.

Fieldhouse, D.K. Economics and Empire, 1830-1914. (Ithaca: Cornell University Press, 1973).

Fowkes, Ben. The Disintegration of the Soviet Union: A Study in the Rise and Triumph of Nationalism. (New York: St. Martin's Press, 1997).

------------------. “The National Question in the Soviet Union under Leonid Brezhnev: Policy and Response," Brezhnev Reconsidered Eds. Edwin Bacon \& Mark Sandle. (New York: Palgrave MacMillan, 2002).

"Friendship of Peoples vs. Nationalism and Localism," Current Digest of the Soviet Press, Vol. XVII, No. 46 (Nov. 1965). 8.

"FY-85 Approval of Operational Activity QRDYNAMIC". Freedom of Information Act Electronic Reading Room. http://www.foia.cia.gov/

Gaddis, John Lewis. We Now Know: Rethinking Cold War History. Oxford: Oxford University Press, 1997.

Gerner, Kristian \& Stefan Hedlund. The Baltic States and the End of the Soviet Empire. London: Routledge, 1993. 
Girnius, Kestutis K. "Catholicism and Nationalism in Lithuania" in Religion and Nationalism in Soviet and East European Politics. Ed. Pedro Ramet. Durham, NC: Duke University Press, 1989.

Gleason, Gregory. Federalism and Nationalism: The Struggle for Republican Rights in the USSR. (Boulder: Westview Press, 1990).

Gorbachev, Mikhail. Memoirs. (New York: Doubleday, 1995).

Hargreaves, John D. Decolonization in Africa. (New York: Longman, 1988).

Harrison, James P. The Endless War: Vietnam's Struggle for Independence. New York: Columbia University Press, 1989.

Hirsch, Francine. Empire of Nations: Ethnographic Knowledge and the Making of the Soviet Union. (Ithaca: Cornell University Press, 2005).

Ho Chi Minh. "Report on the Draft Amended Constitution" in Ho Chi Minh: Selected Writings 1920-1969. Hanoi: Foreign Languages Publishing House, 1973.

Hodge, Joseph Morgan. Triumph of the Expert: Agrarian Doctrines of Development and the Legacies of British Colonialism. (Athens: Ohio University Press, 2007).

Horne, Alistair. A Savage War of Peace: Algeria 1954-1962. New York: The New York Review of Books, 2006.

Hosking, Geoffrey. Russia: People and Empire, 1552-1917. (Cambridge: Harvard University Press, 1997).

-----------------. Rulers and Victims: The Russians in the Soviet Union. (Cambridge: Belknap Press, 2006).

“Information of KGB USSR to CC CPSU International Department, 10 October 1979," Cold War International History Project Bulletin, (Winter 1996/1997).

Kalnins, Ingrida, Ed. The Baltic Tribunal Against the Soviet Union, July 25 \& 26, 1985. Rockville, MD: The World Federation of Free Latvians, 1985.

Kappeler, Andreas. The Russian Empire: A Multiethnic History Tr. Alfred Clayton. (Harlow, England: Longman, 2001).

Karklins, Rasma. "Islam: How Strong Is It in the Soviet Union?" Cahiers du Monde russe et sovietique, Vol. 21, No. 1 (Jan.-Mar. 1980). 66.

Kaufman, Edy. The Superpowers and their Spheres of Influence. London: Croom Helm, 1976. 
Keep, John. Last of the Empires: A History of the Soviet Union 1945-1991. (Oxford: Oxford University Press, 1995).

Keese, Alexander. "A Culture of Panic: 'Communist' Scapegoats and Decolonization in French West Africa and French Polynesia (1945-1957).” French Colonial History, Vol. 9 (2008).

King, Charles. The Moldovans: Romania, Russia, and the Politics of Culture. Stanford: Hoover Institution Press, 2000.

Konstitutsiia (Osnovnoi Zakon) SSSR; Konstitutsiia (Osnovnye Zakony) Soiuznykh i Avtonomnykh Sovetskikh Sotsialisticheskikh Respublik. (Moscow: Gosudarstvennoe Izdatel'stvo Iuridicheskoi Literatury, 1960).

Konstitutsiia (Osnovnoi Zakon) Soiuza Sovetskikh Sotsialisticheskikh Respublik, Konstitutsii (Osnovnye Zakony) Soiuznykh Sovetskikh Sotsialisticheskikh Respublik. (Moscow: Iuridicheskaia Literatura, 1978).

Kosygin, Aleksei. 'Sotsial'no-Ekonomicheskoe Razvitie Sovetskogo Mnogonatsional'nogo Gosudarstva,” Kommunist, No. 17 (1045) (Nov. 1972).

Kozlov, V.I. “Nekotorye Problemy Teorii Natsii,” Voprosy Istorii (Jan. 1967).

Lacouture, Jean. Ho Chi Minh: A Political Biography. Tr. Peter Wiles \& Jane Clark Seitz. New York: Random House, 1968.

Lawal, Olakunle. "From Colonial Reforms to Decolonization: Britain and the Transfer of Power in Nigeria, 1947-1960," Journal of the Historical Society of Nigeria, Vol. 10 (2010).

Lenin, V.I. "Critical Remarks on the National Question," V.I. Lenin: Collected Works, Vol. 20: December 1913-August 1914. (Moscow: Progress Publishers, 1977).

----------. Imperialism: The Highest Stage of Capitalism, A Popular Outline. (New York: International Publishers, 1974).

------------. “Is a Compulsory Official Language Needed?" V.I. Lenin: Collected Works, Vol. 20: December 1913-August 1914. (Moscow: Progress Publishers, 1977).

Ligachev, Yegor. Inside Gorbachev's Kremlin: The Memoirs of Yegor Ligachev. Introduction by Stephen F, Cohen. Tr. Catherine A. Fitzpatrick, Michele Berdy \& Dobrochna DyrezFreeman. (New York: Pantheon Books, 1993).

Louis, William Roger \& Ronald Robinson. "The Imperialism of Decolonization," The Decolonization Reader Ed. James D. LeSueur. (New York: Rutledge, 2003). 
Martin, Terry. The Affirmative Action Empire: Nations and Nationalism in the Soviet Union, 1923-1939. (Ithaca: Cornell University Press, 2001).

Martel, Gordon. "Decolonization After Suez: Retreat or Rationalisation?" Australian Journal of Politics and History, Vol. 26, No. 3 (2000).

Materialy Plenumov TsK KPSS 8 Aprelia 1966 g. - 18 Fevralia 1986. (Fond 2, opis' 3, roll 171 delo 428).

Masherov, Petr. “O Nekotorykh Chertiakh i Osobennostiakh Natsional'nykh Otnoshenii v Usloviiakh Razvitogo Sotsializma,” Kommunist, No. 15 (1043) (Oct. 1972).

Mazrui, Ali A. "Nkrumah: The Leninist Czar”. Transition, No. 75/76 (1997).

McCauley, Martin. The Khrushchev Era 1953-1964. (Harlow, England: Pearson Education, 1995).

Micklin, Philip P. "Desiccation of the Aral Sea: A Water Management Disaster in the Soviet Union,” Science, New Series, Vol. 241, No. 4870 (Sept. 2, 1988). 1170.

Misiunas, Romuald J. \& Rein Taagepera. The Baltic States Years of Dependence, 1940-1990. Expanded and Updated Edition. Berkeley: University of California Press, 1993.

Munkler, Herfried. Empires: The Logic of World Domination from Ancient Rome to the United States. (Malden, Mass.: Polity, 2007).

Nahaylo, Bohdan \& Victor Swoboda. Soviet Disunion: A History of the Nationalities Problem in the USSR. (New York: The Free Press, 1990).

Naumkin, Vitaly V. Radical Islam in Central Asia: Between Pen and Rifle. (Lanham, MD: Rowman \& Littlefield, 2005).

“O dopolnitel'nykh merakh po protivodeistviiu antisovetskoi deiatel'nosti ukrainskikh burzhuazno-natsionalisticheskikh organizatsii za rubezhom." Bukovsky Archive http://bukovsky-archives.net

Olcott, Martha Brill. "Yuri Andropov and the 'National Question'," Soviet Studies, Vol. 37, No. 1 (Jan. 1985).

2007). 6.

Onley, James. “The Raj Reconsidered: British India's Informal Empire and Spheres of Influence in Asia and Africa," Asian Affairs, Vol. XL, No. 1 (March 2009). 
Overy, Richard. Russia's War: A History of the Soviet War Effort, 1941-1945. New York: Penguin Books, 1997.

Peterson, Christian. Routledge Studies on History and Globalization: Globalizing Human Rights: Private Citizens, the Soviet Union, and the West. New York: Routledge, 2012.

Pikhoia, P.G. Sovetskii Soiuz: Istoriia Vlasti, 1945-1991. (Moscow: Izdatel'stvo RAGS, 1998).

Pipes, Richard. The Formation of the Soviet Union: Communism and Nationalism 1917-1923, Revised Edition. (Cambridge: Harvard University Press, 1997).

Pittaway, Mark. Eastern Europe, 1939-2000. New York: Oxford University Press, 2004.

"Podgorny on Nationalities, Economic Reorganization," Current Digest of the Soviet Press, Vol. XVII, No. 21 (June 1965). 4.

Potseluev, Vladimir. Gerby Soiuza SSR: Iz Istorii Razrabotki. Moscow: Izdatel'stvo Politicheskoi Literatury, 1987.

Purs, Aldis. Baltic Facades: Estonia, Latvia, and Lithuania since 1945. London: Reaktion Books, 2012.

Rakowska-Harmstone, Theresa. Russia and Nationalism in Central Asia: The Case of Tadzhikistan. (Baltimore: The Johns-Hopkins Press, 1970).

Ramusack, Barbara. The Indian Princes and their States. Cambridge: Cambridge University Press, 2004.

Rashidov, Sharaf. "Leninskaia Natsional'naia Politika v Deistvii,” Kommunist, No. 15 (1079) (Oct. 1974).

"Report of the Chairman of the Committee for State Security of the Armenian Socialist Soviet Republic M.A. Yuzbashyan,” March 14, 1979, History and Public Policy Program Digital Archive, Armenian National Archives. Tr. Svetlana Savranskaya. http://digitalarchive.wilsoncenter.org/document/117341

Ro'i, Yaacov. Islam in the Soviet Union From the Second World War to Gorbachev. (New York: Columbia University Press, 2000).

Roy, M.N. "The $2^{\text {nd }}$ International and the Doctrine of Self-Determination". Communist International (New Series). No. 4 (1924). https://www.marxists.org/archive/roy/1924/x01/x01.htm

Service, Robert. Stalin: A Biography. (Cambridge: Belknap Press, 2005). 
Snechkus, Anastas. "Velikaia Sila Sotsialisticheskogo Internatsionalizma," Kommunist, No. 11 (1039) (July 1972).

"Soviet National Linguistic Policy Seen as a Model," Current Digest of the Soviet Press, Vol. XVII, No. 47 (Dec. 1965). 14.

Shelest, Petro. Da ne Sudimy Budete: Dnevnikovye Zapisi Vospominaniia Chlena Politbiuro TsK KPSS. (Moscow: Kvintessentsiia, 1995).

Shipway, Martin. Decolonization and its Impact: A Comparative Approach to the End of Colonial Empires. (Malden, Mass.: Blackwell Publishing, 2008).

Stalin, J.V. "Marxism and the National Question," J.V. Stalin: Works, Volume II: 1907-1913. (Moscow: Foreign Languages Publishing House, 1953).

------------. “The National Question and Leninism,” J.V. Stalin: Works, Vol. 11, 1928-March 1929. (Moscow: Foreign Languages Publishing House, 1954).

Staples, John. "Soviet Use of Corruption Purges as a Control Mechanism: The Uzbekistan Case," Past Imperfect, Vol. 2 (1993). 36.

"Stasi Note on Meeting with KGB Officials, 13 November 1969", November 13, 1969, History and Public Policy Program Digital Archive, Office of the Federal Commissioner for the Stasi Records (BStU), MfS, MfS, SdM 577, p. 88-110. Translated from German for CWIHP by Bernd Schaefer. http://digitalarchive.wilsoncenter.org/document/115714

Stockwell, A.J. "Imperialism and Nationalism in South-East Asia," The Oxford History of the British Empire, Vol. IV: The Twentieth Century. Eds. Judith M. Brown \& William Roger Louis. (Oxford: Oxford University Press, 1999).

Subtelny, Orest. Ukraine: A History. Second Edition. Toronto: University of Toronto Press, 1994.

Suny, Ronald Grigor. The Soviet Experiment: Russia, the USSR and the Successor States. (New York: Oxford University Press, 1998).

The Making of the Georgian Nation, Second Edition. (Bloomington: Indiana University Press, 1994).

Svanberg, Ingvar. "Kazakhs," The Nationalities Question in the Soviet Union Ed. Graham Smith. (London: Longman, 1990).

Taubman, William. Khrushchev: The Man and His Era. New York: W.W. Norton, 2003. 
Tauger, Mark. "Stalin, Soviet Agriculture and Collectivization," Food and Conflict in Europe in the Age of the Two World Wars. Eds. Frank Trentmann \& Fleming Just. (New York: Palgrave MacMillan, 2006).

Tavakalian, N.A. "Nekotorye Voprosy Poniatiia 'Natsiia'," Voprosy Istorii (February 1967).

Tchoroev, Tyntchtybek. "Chingiz Aitmatov's Lifelong Journey Toward Eternity," Radio Free Europe/Radio Liberty (Dec. 12, 2008) http://www.rferl.org/content/Chyngyz_Aitmatovs_Lifelong_Journey_Toward_Eternity/1 $\underline{359041 . h t m l}$ (Accessed July 12, 2014).

Tepeyurt, Mehmet. Bashkirs Between Two Worlds, 1552-1824. Ph.D. Dissertation. (Morgantown: West Virginia University, 2011).

"The Final Act of the Conference on Security and Cooperation in Europe, August 1, 1975". http://www1.umn.edu/humanrts/osce/basics/finact75.htm

"The Origin and Aims of The Chronicle of the Catholic Church in Lithuania" http://lkbkronika.lt/en/index.php?option=com_content $\& v i e w=\operatorname{article} \& \mathrm{id}=344 \&$ Itemid=2 $\underline{29}$

Tismaneanu, Vladimir. Reinventing Politics: Eastern Europe from Stalin to Havel. New York: The Free Press, 1992.

Tompson, William. The Soviet Union Under Brezhnev. (London: Pearson Education, 2003).

Valentei, D.I. et. al., Eds. Demograficheskii Entsiklopedicheskii Slovar'. (Moscow: Sovetskaia Entsiklopediia, 1985).

Van Walraven, Klaas. "Decolonization by Referendum: The Anomaly of Niger and the Fall of Sawaba, 1958-1959." The Journal of African History, Vol. 50, No. 2 (2009).

Velychenko, Stephen. "Ukrainian Anticolonialist Thought in Comparative Perspective: A Preliminary Overview." Ab Imperio, 4/2012.

Volkogonov, Dmitri. Autopsy for an Empire: The Seven Leaders Who Built the Soviet Regime. Tr. Harold Shukman. (New York: The Free Press, 1998).

Ward, Christopher J. Brezhnev's Folly: The Building of BAM and Late Soviet Socialism. (Pittsburgh: University of Pittsburgh Press, 2009).

White, Nicholas J. "The Business and the Politics of Decolonization: The British Experience in the Twentieth Century," Economic History Review, Vol. LIII; No. 3 (2000). 
- "The Frustrations of Development: British Business and the Late Colonial State in Malaya, 1945-57," Journal of Southeast Asian Studies, Vol. 28, No. 1 (March 1997).

Whitehead, Clive. "The Medium of Instruction in British Colonial Education: A Case of Cultural Imperialism or Enlightened Paternalism?" History of Education, Vol. 24, No. 1 (1995).

Weber, Bruce. "Chingiz Aitmatov Who Wrote of Life in USSR Is Dead at 79," The New York Times (June 15, 2008).

Webber, Mark. "Out of Area Operations: The Third World," Brezhnev Reconsidered Eds. Edwin Bacon \& Mark Sandle. (New York: Palgrave MacMillan, 2002).

Westad, Odd Arne. The Global Cold War: Third World Interventions and the Making of Our Times. (Cambridge: Cambridge University Press, 2007).

Winks, Robin W. "On Decolonization and Informal Empire," The American Historical Review, Vol. 81, No. 3 (June 1976).

XIV S"ezd Kommunisticheskoi Partii Kirgizii, 3-4 Marta 1966g. Stenograficheskii Otchet. (Frunze: Kirgizstan, 1980).

XV S”ezd Kommunisticheskoi Partii Kirgizii, 3-5 Marta 1971goda (Stenograficheskii Otchet). (Frunze: Izdatel'stvo Kirgizstan, 1978).

XVI S"ezd Kommunisticheskoi Partii Kirgizii, 16-18 Ianvaria 1976 goda (Stenograficheskii Otchet). (Frunze: Izdatel'stvo Kirgizstan, 1976).

XVII S"ezd Kommunisticheskoi Partii Kirgizii, 20-22 Ianvaria 1981 goda (Stenograficheskii Otchet). (Frunze: Izdatel'stvo Kirgizstan, 1981).

XVIII S"ezd Kommunisticheskoi Partii Tadzhikistana, 27-29 Ianvaria 1976 goda, Stenograficheskii Otchet. (Dushanbe: Irfon, 1977).

XIX S”ezd Kommunisticheskoi Partii Tadzhikistana, 23-25 Ianvaria 1981 goda, Stenograficheskii Otchet. (Dushanbe: Irfon, 1983).

XXIV S"ezd Kommunisticheskoi Partii Ukrainy, 17-20 Marta 1971 goda, Stenograficheskii Otchet. (Kiev: Izdatel'stvo Politicheskoi Literatury Ukrainy, 1972).

XXV S"ezd Kommunisticheskoi Partii Ukrainy, 10-13 Fevralia 1976 goda, Stenograficheskii Otchet. (Kiev: Izdatel'stvo Politicheskoi Literatury Ukrainy, 1976). 
XIX S"ezd Kommunisticheskoi Partii Uzbekistana, 3-5 Fevralia 1976 goda, Stenograficheskii Otchet. (Tashkent: Izdatel'stvo Uzbekistan, 1978).

XX S"ezd Kommunisticheskoi Partii Uzbekistana, 3-5 Fevralia 1981 goda, Stenograficheskii Otchet. (Tashkent: Uzbekistan, 1982).

XXVI S"ezd Kommunisticheskoi Partii Sovetskogo Soiuza 23 Fevralia-3 Marta 1981 goda, Stenograficheskii Otchet. (Moscow: Izdatel'stvo Politicheskoi Literatury, 1981).

Zaslavsky, Victor. "The Soviet Union,” After Empire: Multiethnic Societies and NationBuilding: The Soviet Union and the Russian, Ottoman and Habsburg Empires. Eds. Karen Barkey \& Mark von Hagen. (Boulder: Westview Press, 1997).

Zisserman Brodsky, Dina. Constructing Ethnopolitics in the Soviet Union: Samizdat, Deprivation and the Rise of Ethnic Nationalism. (New York: Palgrave MacMillan, 2003).

Zubok, Vladislav. A Failed Empire: The Soviet Union in the Cold War from Stalin to Gorbachev. (Chapel Hill: UNC Press, 2007). 